Moleculaire verontreiniging in gerecyclede kunststoffolie uit bron- en nascheiding 



\section{Moleculaire verontreiniging in gerecyclede kunststoffolie uit bron- en nascheiding}

Instituut: Wageningen Food \& Biobased Research

Auteurs: E. Maaskant-Reilink, E.U. Thoden van Velzen, I.W. Smeding

Dit onderzoek is uitgevoerd door Wageningen Food \& Biobased Research in opdracht van Gemeente Utrecht (projectnummer 6229087300). 
Versie: definitief

Reviewer: D. van Es

Goedgekeurd door: A. van der Bent

Opdrachtgever: Gemeente Utrecht

Financiers: Gemeente Utrecht, Gemeente Den Haag, Gemeente Amsterdam en LCKVA

Dit rapport is gratis te downloaden op https://doi.org/10.18174/518646 of op www.wur.nl/wfbr (onder publicaties).

(C) 2020 Wageningen Food \& Biobased Research, instituut binnen de rechtspersoon Stichting Wageningen Research.

Het is de opdrachtgever toegestaan dit rapport integraal openbaar te maken en ter inzage te geven aan derden. Zonder voorafgaande schriftelijke toestemming van Wageningen Food \& Biobased Research is het niet toegestaan:

a. dit door Wageningen Food \& Biobased Research uitgebrachte rapport gedeeltelijk te publiceren of op andere wijze gedeeltelijk openbaar te maken;

b. dit door Wageningen Food \& Biobased Research uitgebrachte rapport, c.q. de naam van het rapport of Wageningen Food \& Biobased Research, geheel of gedeeltelijk te doen gebruiken ten behoeve van het instellen van claims, voor het voeren van gerechtelijke procedures, voor reclame of antireclame en ten behoeve van werving in meer algemene zin;

c. de naam van Wageningen Food \& Biobased Research te gebruiken in andere zin dan als auteur van dit rapport.

Postbus 17, 6700 AA Wageningen, T 03174800 84, E info.wfbr@wur.nl, www.wur.nl/wfbr. Wageningen Food \& Biobased Research is onderdeel van Wageningen University \& Research.

Alle rechten voorbehouden. Niets uit deze uitgave mag worden verveelvoudigd, opgeslagen in een geautomatiseerd gegevensbestand of openbaar gemaakt in enige vorm of op enige wijze, hetzij elektronisch, hetzij mechanisch, door fotokopieën, opnamen of enige andere manier, zonder voorafgaande schriftelijke toestemming van de uitgever. De uitgever aanvaardt geen aansprakelijkheid voor eventuele fouten of onvolkomenheden. 


\section{Inhoud}

Samenvatting 5

Summary 7

$\begin{array}{lr}\text { Afkortingenlijst } & 10\end{array}$

$\begin{array}{ll}\text { 1. Inleiding } & 11\end{array}$

1.1 Achtergrond van het project 11

1.2 Onderzoeksvragen 11

1.3 Achtergrondinformatie 12

$\begin{array}{ll}1.4 \text { Opbouw van dit rapport } & 15\end{array}$

2. Generieke onderzoeksmethoden 16

2.1 Monster opslag en transport $\quad 16$

2.2 Hexaanextractie 16

2.3 Infrarood spectroscopie 16

2.4 Screening voor vluchtige stoffen 16

2.5 Screening voor gemiddeld tot niet vluchtige stoffen 17

$\begin{array}{ll}2.6 \text { Geurpanelanalyse } & 17\end{array}$

2.7 Mechanische recycling 18

3. Taak 1: Verschil in moleculaire verontreiniging tussen gerecyclede kunst-stoffolies uit $\begin{array}{ll}\text { bronscheiding en nascheiding } & 20\end{array}$

3.1 Onderzoeksmethode 20

3.1.1 Taak 1a 20

3.1.2 Taak $1 \mathrm{~b} \quad 21$

3.2 Resultaten en discussie $\quad 21$

3.2.1 Moleculaire verontreiniging in Albert Heijn tassen (Taak 1a) 21

3.2.2 Moleculaire verontreiniging in een deelmonster (Taak 1b)

3.3 Deelconclusie 31

$4 \quad$ Taak 2: Invloed recyclingwijze op de moleculaire verontreiniging 32

4.1 Onderzoeksmethode 32

4.2 Resultaten en discussie 33

4.3 Deelconclusie $\quad 39$

5. Taak 3: Invloed van scheidingsgedrag op moleculaire verontreiniging 40

5.1 Onderzoeksmethode 40

5.2 Resultaten en discussie $\quad 40$

5.3 Deelconclusie 42

6. Taak 4: Invloed ledigingsfrequentie op moleculaire verontreiniging 43

6.1 Onderzoeksmethode 43

6.2 Resultaten en discussie $\quad 43$

6.3 Deelconclusie 48

$\begin{array}{ll}\text { 7. Discussie } & 49\end{array}$

7.1 Massarendement $\quad 49$

7.2 Kwaliteit $\quad 50$

7.3 Eindoordeel 53 
8. Conclusies

Literatuur

Bijlage 1 Additionele data taak 1a

59

Bijlage 2 Additionele data taak 1b

68

Bijlage 3 Additionele data taak 2

74

Bijlage 4 Additionele data taak 3

87

Bijlage 5 Additionele data taak 4

90 


\section{Samenvatting}

Huishoudelijk kunststofverpakkingsafval wordt op diverse manieren ingezameld en gerecycled. Voor inzameling zijn er twee veel voorkomende methodes: bronscheiding en nascheiding. Bij bronscheiding (gescheiden inzameling) wordt het kunststofverpakkingsafval al bij het huishouden apart gehouden van het restafval. Bij nascheiding gebeurt inzameling samen met het restafval. Na inzameling worden de kunststofverpakkingen machinaal uit het gemengde huishoudelijke restafval teruggewonnen. Uit eerder onderzoek is al e.e.a. bekend over verschillen tussen beide inzamelmethoden met betrekking tot massarendement en polymere zuiverheid. Echter over of er verschil is in moleculaire verontreiniging (met name geur) is nog weinig bekend.

Dit rapport beschrijft een verkennende analyse van de moleculaire verontreiniging die aanwezig is in gerecyclede kunststoffen afkomstig uit bronscheiding en nascheiding. Dit onderzoek werd begrensd tot het sorteerproduct Folie (DKR $\left.{ }^{1} 310\right)$ omdat dit materiaal veel geuren op kan nemen ten opzichte van andere kunststoffen en dus fungeert als een worst-case. Vier verschillende onderzoeksvragen werden verkennend onderzocht.

1. Is er verschil in moleculaire verontreiniging tussen brongescheiden kunststoffolie en nagescheiden kunststoffolie?

2. Welke invloed heeft de recyclingwijze op de moleculaire verontreiniging in het kunststoffolie?

3. Wat is de invloed van het scheidingsgedrag op de moleculaire verontreiniging?

4. Wat is de invloed van de ledigingsfrequentie op de moleculaire verontreiniging? Het onderzoek werd uitgevoerd met drie verschillende analysemethoden: hexaanextractie (om vetoplosbare bestanddelen te extraheren en dat als totaal te kwantificeren), gaschromatografie gekoppeld aan massaspectrometrie (GC-MS, om vluchtige en niet vluchtige componenten te bepalen) en een geurpanel (om daadwerkelijk de geur te classificeren). Op verschillende soorten materiaal zijn testen uitgevoerd: een specifieke verpakking uit het gesorteerde folieproduct, het gerecycled folieproduct (maalgoed en granulaat) en schoon polyetheen-folie (PE) dat werd toegevoegd aan het afval.

\section{Is er verschil in moleculaire verontreiniging tussen bronscheiding en nascheiding?}

Het verschil in moleculaire verontreiniging tussen brongescheiden en nagescheiden kunststoffolie werd onderzocht met GC-MS en een geurpanel aan zowel één gekozen LDPE-folie-product als aan een groter monster van het totale folie-sorteerproduct. De gaschromatogrammen lieten een grote hoeveelheid pieken zien, wat aangeeft dat er veel verschillende vluchtige stoffen in de folie zijn aangetroffen (elke piek correspondeert met een organische verbinding). Daarom was het lastig om de individuele moleculen te identificeren. De meeste moleculen die konden worden geïdentificeerd waren oligomeren van PE, afbraakproducten van PE en een enkel bewust toegevoegd additief (weekmakers uit bedrukking, antioxidant). Op een enkele uitzondering na, konden geen geur-actieve stoffen worden geïdentificeerd met GC-MS, aangezien de gaschromatogrammen overvol waren met vluchtige verbindingen. Het met koud water gewassen gerecyclede materiaal (maalgoed) is ook voorgelegd aan een geurpanel; dat leverde meer informatie op. Beide folies geuren, maar op een verschillende manier. Folie-materiaal dat afkomstig is uit bronscheiding ruikt vooral ranzig, nootachtig. Foliemateriaal dat afkomstig is uit nascheiding ruikt vooral aards en muf.

\section{Wat is de invloed van de recyclingwijze op de moleculaire verontreiniging?}

Twee stappen in het recyclingproces hebben mogelijk invloed op de moleculaire verontreiniging van gerecyclede kunststoffen; de waswijze en het ontgassen met vacuüm tijdens het extruderen van het recyclaat. Dit werd onderzocht op een groter monster van het folie-sorteerproduct met GC-MS en een geurpanel. Ook hier bleek dat GC-MS analyses zoveel pieken (verschillende aanwezige moleculen) lieten zien dat er moeilijk een verschil tussen de recyclingwijzen uit kon worden opgemaakt. Een geurpanel gaf meer informatie. Folie-materiaal dat afkomstig is uit bronscheiding en op verschillende

\footnotetext{
${ }^{1}$ DKR specificaties zijn standaarden voor kwaliteit en zuiverheid van sorteerproducten, zoals vastgesteld door DKR https://www.gruener-punkt.de/de/downloads.html
} 
manieren is gerecycled en geëxtrudeerd blijft steeds vettig, ranzig, fruitachtig en amandelachtig ruiken. Uit de GC-MS analyses bleek dat warm wassen met loog en vacumeren de hoogte van de pieken (oftewel de concentratie van de aanwezige moleculen) wel verminderde, maar dat volgens het geurpanel deze behandelingen de geur niet beïnvloedden. Dit betekent dat de mate waarin de geuractieve moleculen worden verwijderd onvoldoende is om de geur te veranderen. Sommige stoffen ruik je ook al bij een lage concentratie. Dit betekent echter niet dat wassen geen zin heeft, want concentraties van een deel van de aanwezige moleculen zijn wel daadwerkelijk verlaagd.

Bij folie-materiaal dat afkomstig is uit nascheiding heeft de recyclingwijze en extrusie juist wel een grote invloed op de geur. In koud water gewassen, ruikt het nagescheiden folie-materiaal scherp verbrand na verhitting bij extrusie, maar na wassen in warm water ontstaat deze geur niet bij extrusie en ruikt het gewassen folie juist zeepachtig, aards en muf. Vermoedelijk kunnen de moleculen die de scherp-verbrande geur veroorzaken gemakkelijk uit het folie worden gewassen met warm water, waarna de aards muf ruikende moleculen overblijven die daarna het geurprofiel vormen. Ook bij nascheiding nemen de hoogtes van de pieken (en dus de concentratie van de moleculen) in het gaschromatogram af, maar dit leidt niet tot een beter interpreteerbaar resultaat, ook worden er geen nieuwe pieken zichtbaar.

\section{Welk effect heeft scheidingsgedrag op de kwaliteit van het recyclaat?}

Het scheidingsgedrag werd onderzocht in drie verschillende wijken waar verschillend ingezameld werd: gescheiden PMD (Plastic, Metaal, Drankkartons) of plastic in restafval, al dan niet gecombineerd met een hoge participatiegraad in het gescheiden inzamelen van groente- en fruitafval. Dit is onderzocht op het niveau van één specifiek folie-product. Het bleek erg lastig, om - ondanks de omvang van de monsters - hetzelfde folieproduct te vinden in het materiaal van alle drie de wijken. Het enige folieproduct dat in alle bestudeerde afvalstromen voorkwam was een draagtas van een supermarktketen. Dit werd bestudeerd met hexaanextractie en GC-MS. De hexaanextractie waarde, die een indicatie geeft van de hoeveelheid vetoplosbare stoffen in een materiaal, bleek behoorlijk te variëren tussen monsters. Waarschijnlijk wordt deze waarde overheerst door de PE oligomeren en afbraakproducten en kunnen verschillen in andere geur-actieve verontreinigingen hier niet uit afgelezen worden. De gaschromatogrammen waren zeer druk met heel veel pieken; dit duidt op veel moleculaire verontreiniging. Behalve de pieken die aan PE-oligomeren en afbraakproducten kunnen worden toegekend, waren er ook grote pieken van incidentele verontreinigingen zoals verfresten, spierpijn-crème en olijfolie. Deze incidentele verontreinigingen kwamen zowel voor in brongescheiden materiaal als in nagescheiden materiaal. Hierdoor kon geen conclusie worden getrokken over de invloed van de inzamelwijze op de kwaliteit van het recyclaat. In de toekomst kan dit materiaal beter worden onderzocht op het niveau van (grotere) sorteerproducten die uit deze wijken zijn verkregen, gecombineerd met een analyse door een geurpanel.

\section{Welk effect heeft blootstellingsduur aan ander afval op de moleculaire verontreiniging}

De invloed van de ledigingsfrequentie op moleculaire verontreiniging werd onderzocht door schoon PE folie in contact te brengen met zowel restafval als PMD en elke week foliestukken hieruit te verwijderen. Deze foliestukken zijn iedere week visueel beoordeeld, en ook is een hexaanextractie uitgevoerd. Daarnaast is na vier weken een GC-MS analyse uitgevoerd. Het folie dat in contact was gebracht met restafval was deels geelbruin verkleurd en dit was niet gebeurd voor het folie dat met PMD in contact was gebracht. Uit de resultaten van de hexaanextractie kon niet echt een verschil worden opgemaakt tussen de folies die in contact waren met restafval en met PMD materiaal, vermoedelijk omdat in dit getal de PE oligomeren en afbraakproducten domineren. Bovendien was in de hexaanextractie waarden geen trend te zien in de wekelijkse metingen en kon er dus geen duidelijk effect van de inzamelfrequentie uit worden opgemaakt. De GC-MS analyses na 4 weken bevatten veel minder pieken dan van gerecycled gemengd folie-materiaal en waren beter te bestuderen. Toch waren de verschillen tussen beide analyses gering. In de toekomst kan het folie beter worden beoordeeld door een geurpanel op verschillende tussentijdse momenten.

Op basis van dit verkennende onderzoek lijkt er geen significant verschil te zijn tussen moleculaire verontreiniging van gerecycled materiaal teruggewonnen uit bron- en nascheiding. Beide materialen geuren, maar op een andere manier. De uiteindelijke keuze voor een inzamelsysteem zal afhangen van de bredere context waarin veel factoren een rol spelen: niet alleen de technische aspecten, maar ook economische en sociaal maatschappelijke factoren. 


\section{Summary}

There are different ways of collecting and recycling post-consumer packaging waste. There are two main methods for the collection: separate collection and mechanical recovery of plastics from mixed municipal solid waste (MSW). Separate collection implies that the civilians keep their packaging waste separated from the MSW and offer it for separate collection. Whereas, with mechanical recovery the civilians discard their packaging waste with the MSW and at a central mechanical recovery facility (MRF) the packaging waste is recovered from the MSW by machines. The effect of the chosen collection system on, for example, the mass efficiency or polymer purity is already known from previous studies. The effect on molecular contamination (in particular odour), on the other hand, is not well-studied yet.

This report discusses an explorative study on the molecular contamination in post-consumer packaging waste from both separate collection and mechanical recovery. This study focusses only on the sorted product foil $\left(\mathrm{DKR}^{2} 310\right)$ because this material is known to take up more odour/contamination as compared to other types of plastics, and can therefore be regarded as a worst-case scenario. Four research questions were exploratively studied:

1. Is there a difference in the molecular contamination between separately collected and mechanically recovered plastic packaging films?

2. What is the effect of the recycling method on the molecular contamination?

3. What effect has consumer behaviour on the quality of the recycled plastic?

4. What is the effect of exposure time to the carrier waste on the molecular contamination?

Three different characterisation methods were used in this study: extraction with hexane (to quantify the concentration of non-polar, lipophilic substances), gas chromatography coupled with mass spectrometry (GC-MS, to identify volatile and medium to non-volatile compounds), and sensory panel analysis (to characterise odour attributes). Tests were performed on different materials: one specific type of packaging from the foil sorted product, milled goods/flakes and granulate obtained from the recycling of a larger subsample of the foil sorted product, and clean PE-foil that purposely has been added to waste.

1. Is there a difference in molecular contamination between separate collected and mechanically recovered plastics?

The difference between molecular contamination in PE-foil sorted product obtained from two waste collection systems was studied by GC-MS and a sensory panel analysis for both one specific product as well as a larger sample for the sorted product. The gas chromatograms were in all cases packed with peaks (each peak corresponds to an unique molecule), which indicates the presence of a lot of volatile and medium to non-volatile compounds. Due to the huge amount of peaks, not all molecules could be identified. Most of the identified medium to non-volatile molecules were assigned to PE-oligomers, PE degradation products, and additives such as plasticizers used in inks or anti-oxidants. The volatile molecules could not be identified at all due their huge amount. The milled goods that were washed with cold water were characterised by a sensory panel. Recycled material from separate collection had a rancid nut-like odour, while recycled material from a MRF had an earthy, musty odour.

\section{What is the effect of the recycling method on the molecular contamination?}

There are two steps in the recycling chain that potentially have an effect on the molecular contamination in recycled materials; the washing method to produce the milled goods/flakes, and the use of vacuum during extrusion of the milled goods/flakes to remove volatiles. The effect of these two steps is studied in this task on a larger sample of PE-foil sorted product by GC-MS analysis and sensory panel analysis. Again, the GC-MS resulted in spectra fully packed with peaks (each peak

\footnotetext{
${ }^{2}$ DKR specifications are standards for the quality and purity of sorted products, as established by DKR https://www.gruener-punkt.de/de/downloads.html
} 
corresponds to a unique molecule), and no significant differences could be observed between the collection methods. In contrast, the sensory panel analysis did result in some significant differences between the collection methods. Independent of the way of washing and extrusion conditions, recycled materials originating from separate collection had a fatty, rancid, fruity/almond-like odour. Although the odour is not strongly affected by the recycling method, the intensity of the peaks observed in the gas chromatograms decreased after washing with warm water plus a base and after extrusion with vacuum. From this, it can be concluded that washing and extrusion does remove some molecules but that this is insufficient to remove all odour active compounds. This does, however, not indicate that washing is completely useless. The concentration of many molecules is decreased after washing. Unfortunately, some of these molecules are already odour active at very low concentrations.

The recycling method and extrusion have, in contrast to the PE-foil sorted product from separate collection, a strong influence of the recycled material's odour when the PE-foil sorted product was obtained from a MRF. After washing with cold water and extrusion, the recycled material had a strong burnt odour. This odour is produced during the hot extrusion process. When the sorted product was washed with warm water or with a base, the recycled material had a soapy, detergent-like, earthy, musty odour profile. Apparently, the molecules that cause these burnt odour can easily be removed by washing with warm water. The intensity of the peaks in the gas chromatograms does decrease for recycled material obtained from MRF as well, like in separate collection, but identification of all peaks was still not feasible.

\section{What effect has consumer behaviour on the quality of the recycled material?}

The effect of consumer behaviour on the quality of the recycled material was studied in three different neighbourhoods, all with a different combination of the applied collection system and consumer behaviour (the willingness to participate). The studied material in this task was limited to one specific product, a carrier bag from a large supermarket chain, since this was the only sufficiently available product, despite the large sample taken, in all collected samples from the different neighbourhoods. The molecular contamination in these carrier bags was studied using hexane extraction and GC-MS. The extracted amount resulting from hexane extraction gives an indication of the amount of non-polar (lipophilic) compounds in a material. This value showed a strong deviation between the samples from the different neighbourhoods. This value, however, is mainly based on the presence of PE-oligomers and degradation products. Therefore, this method is not sensitive to draw conclusions on the amount of molecular contamination and/or odour active compounds. The gas chromatograms of the carrier bags from different neighbourhoods showed in all cases a huge amount of peaks, indicating the presence of a lot of different molecules. In addition to the peaks that could be assigned to PEoligomers and degradation products, peaks caused by incidental contaminations could be assigned. Examples of possible products causing these contaminations are paint residues, (muscle pain relief) creams, or (olive)oils. The presence of these incidental contaminations was independent of the way of waste collection. Due to these incidental contaminations, no conclusions can be drawn on the effect of the applied collection system and consumer behaviour on the quality of the recycled material. In future research, it is recommended to not select one specific product but to perform the analysis on a larger sample containing multiple products. Additionally, it is recommended to include a sensory panel to study the odour of the recycled material, since not all molecules detected by GC-MS have the same odour activity.

\section{What is the effect of exposure time to carrier waste on the molecular contamination?}

The effect of exposure time to carrier waste on the molecular contamination was studied by mixing virgin (clean) PE-foil with either separately collected lightweight packaging waste or MSW. Once every week, pieces of foil were collected, inspected visually, and a hexane extraction was performed. In addition, a GC-MS analysis was performed after four weeks contact with the carrier waste. The foil that has been in contact with MSW showed some spots that had a significant brown/yellow discoloration, while the foil that has been in contact with separately collected lightweight packaging waste did not show this discoloration. The results of the hexane extraction, however, did not show a significant difference between the two types of waste, neither did it show a significant difference over time for both types of waste. The insensitivity of the hexane extraction can be explained by the large weight excess of PE-oligomers and degradation products over the molecular contamination. Therefore, 
the effect of exposure time (and thus collection frequency) could not be answered by hexane extraction. The gas chromatograms of the PE-foils showed much less peaks as compared to the gas chromatograms of mixed plastic foils from the previous tasks, making them easier to interpret. The amount of additional peaks after being in contact with waste was for both types of waste limited. It is recommended to study the odour of the PE-foils over time by a sensory panel, since peaks in the GC-MS analysis cannot be directly coupled to odour perception.

It can be concluded, based on the results of this exploratory study, that there is no significant difference in the molecular contamination in recycled material originating from separate collection or mechanical recovery. Both recycled materials have an odour, but the main attributes differ. The preferred collection system should be chosen by taking a broader context into account: not only technical aspects but also economic and societal aspects should be taken into account. 


\section{Afkortingenlijst}

\begin{tabular}{|c|c|}
\hline ATBC & Acetyltributylcitraat \\
\hline ATR-FTIR & Attenuated total reflectance Fourier transform infrared spectroscopy \\
\hline B1 & Monster 1 afkomstig uit bronscheiding \\
\hline $\mathrm{BHA}$ & Butylhydroxyanisol \\
\hline DEHA & bis(2-Ethylhexyl)adipaat \\
\hline DEHP & bis(2-Ethylhexyl)ftalaat \\
\hline DEHT & bis(2-Ethylhexyl)tereftalaat \\
\hline DINCH & Di-isononyl-1,2-cyclohexaandicarboxylaat \\
\hline GC & Gaschromatografie \\
\hline GC-FID & Gaschromatografie gekoppeld met een vlamionisatie detector \\
\hline GC-MS & Gaschromatografie gekoppeld met massaspectrometrie \\
\hline GF & Groente- en fruitafval \\
\hline HDPE & Hogedichtheidpolyetheen \\
\hline IVV & Institut für Verfahrenstechnik und Verpacken \\
\hline km-e & Monster is gewassen met koud water met natronloog en daarna geëxtrudeerd \\
\hline kz & Monster is gewassen met koud water zonder natronloog \\
\hline kz-e & Monster is gewassen met koud water zonder natronloog en daarna geëxtrudeerd \\
\hline kz-ev & $\begin{array}{l}\text { Monster is gewassen met koud water zonder natronloog en daarna geëxtrudeerd met } \\
\text { vacuüm }\end{array}$ \\
\hline LC KVA & Learning Centre Kunststofverpakkingsafval \\
\hline LDPE & Lagedichtheidpolyetheen \\
\hline LVP & Leichtverpackung; Duitse benaming voor bronscheiding \\
\hline LWP & Lightweight packaging waste; Engelse benaming voor bronscheiding \\
\hline MOSH & Mineral oil saturated hydrocarbons; verzadigde koolwaterstoffen \\
\hline N1 & Monster 1 afkomstig uit nascheiding \\
\hline NIR & Near-infrared spectroscopy \\
\hline OPK & Oud papier, karton \\
\hline PE & Polyetheen \\
\hline PP & Polypropeen \\
\hline ppm & Parts per million, delen per miljoen \\
\hline PET & Polyethyleentereftalaat \\
\hline PMC & $\begin{array}{l}\text { Bouteilles et flacons en plastique, emballages métalliques et cartons à boissons; Franse } \\
\text { benaming voor bronscheiding }\end{array}$ \\
\hline PMD & Plastic, metaal, drankkartons \\
\hline PVC & Polyvinylchloride \\
\hline RDF & Refuse derived fuel \\
\hline rPET & Gerecycleerd polyethyleentereftalaat \\
\hline wm-e & Monster is gewassen met warm water met natronloog en daarna geëxtrudeerd \\
\hline wm-ev & $\begin{array}{l}\text { Monster is gewassen met warm water met natronloog en daarna geëxtrudeerd met } \\
\text { vacuüm }\end{array}$ \\
\hline wz-e & Monster is gewassen met warm water zonder natronloog en daarna geëxtrudeerd \\
\hline
\end{tabular}




\section{Inleiding}

\subsection{Achtergrond van het project}

Dit rapport beschrijft de uitkomsten van een project dat is uitgevoerd bij Wageningen Food \& Biobased Research voor diverse opdrachtgevers in 2019/2020. De oorspronkelijke onderzoeksvragen werden gesteld door twee medewerkers van de gemeente Utrecht, de heren Gerhard Schoonvelde en Frank Donkers. In het voorjaar van 2018 zochten zij contact met Wageningen Food \& Biobased Research met de vraag wat er in de wetenschap bekend is over de kwaliteit van gerecycled kunststof gemaakt uit brongescheiden en nagescheiden kunststofverpakkingsafval. Na enkele gezamenlijke overleggen met Ulphard Thoden van Velzen, Maurits Burgering en Ingeborg Smeding van Wageningen Food \& Biobased Research werden onderzoeksvragen gedefinieerd. Aangezien de onderzoeksvragen complexe analysetechnieken vereisen, waar een Duits collega instituut veel ervaring mee heeft, is het deel van het onderzoek dat betrekking had op deze metingen uitbesteed aan dit Duitse onderzoeksinstituut. De heer Frank Welle van het Fraunhofer-Institut für Verfahrenstechnik und Verpacken fungeerde hiermee als onderaannemer. Omdat de onderzoeksvragen breed leven in een grote groep gemeenten en bij het Learning Centre voor kunststofverpakkingsafval van Rijkswaterstaat, werd er een groep van financiers gevormd. Hierbij is de heer Gerhard Schoonvelde formeel opdrachtgever en aanspreekpunt. Het project is mede gefinancierd door: Gemeente Amsterdam, Gemeente Den Haag, Learning Centre Kunststofverpakkingsafval (LC KVA) van Rijkswaterstaat, die in persoon vertegenwoordigd werden door respectievelijk: Stef le Fevre, Jan Harko Post en Cees Riksen \& Marijn Teernstra. Het onderzoek werd uitgevoerd tussen april 2019 en maart 2020 bij Wageningen Food \& Biobased Research te Wageningen en Fraunhofer-Institut für Verfahrenstechnik und Verpacken te Freising. Het onderzoek werd onafhankelijk uitgevoerd en de resultaten werden uitgebreid besproken tussen beide onderzoeksgroepen en becommentarieerd, het hieruit volgende rapport werd volgens de procedures intern gereviewd. De opdrachtgevers verzochten gezamenlijk om een Nederlandstalig onderzoeksrapport, dat geschreven is door de onderzoekers uit Wageningen, waarbij de inhoud op voorhand was afgestemd met de Duitse onderzoekers.

\subsection{Onderzoeksvragen}

Uit de dialoog tussen de opdrachtgevers en de wetenschappers van Wageningen Food \& Biobased Research kwamen de volgende onderzoeksvragen naar voren:

1. Wat is het verschil in moleculaire vervuiling tussen gewassen maalgoed uit bronscheiding (gescheiden inzameling) en uit nascheiding?

2. Wat is de invloed van de was-omstandigheden (temperatuur en gebruik loog) op de moleculaire vervuiling? En kunnen keuzes in het recyclingproces de verschillen in het ingezamelde materiaal (vanuit bron- en nascheiding) teniet doen?

3. Welk effect heeft het verschil in scheidingsgedrag in een wijk op de kwaliteit van het uiteindelijke kunststof-recyclaat dat via bron- dan wel nascheiding wordt verkregen? Hierbij worden drie inzamelsituaties onderscheiden:

a. Kunststof, nagescheiden uit restafval met groot aandeel groente- en fruitafval. In wijken met lage participatiegraad voor de gescheiden inzameling van groente- en fruitafval (GF), verwacht je dat de kunststoffen in het restafval meer moleculaire verontreinigingen opnemen en dat de hieruit gemaakte gerecyclede kunststoffen ook meer moleculaire vervuiling zal bevatten, maar klopt dat ook?

b. Kunststof, nagescheiden uit restafval met een klein aandeel groente- en fruitafval. In wijken met een brengsysteem voor Plastic, metalen en drankkartons (PMD) met beperkte dekking en dus een lage participatiegraad, komt er relatief veel kunststof in het restafval terecht. Tegelijkertijd hebben sommige van deze wijken wel een hoge participatiegraad voor de gescheiden inzameling van GF door het haalsysteem. Hierdoor verwacht je dat de 
kunststoffen in het restafval van deze wijken minder moleculaire verontreiniging opnemen dan die uit de hoogbouwwijken, maar klopt dit ook?

c. Kunststof, brongescheiden ingezameld met een haalsysteem. Brongescheiden

ingezamelde kunststof in laagbouwwijken met PMD-haalsysteem met relatief hoge

participatiegraad, ook voor GF en oud papier/karton (OPK). Het kunststof materiaal heeft naar verwachting minder moleculaire vervuiling omdat het brongescheiden is, maar klopt dit ook?

4. Welk effect heeft de blootstellingsduur aan ander afval op de moleculaire vervuiling van nagescheiden recyclaat? Heeft het wel of geen zin om de inzamelfrequentie te verhogen voor PMD en restafval om de kwaliteit van het recyclaat te verbeteren?

Het in dit rapport beschreven onderzoek geeft antwoord op deze onderzoeksvragen en is gestructureerd in vier taken die direct verband houden met deze vier onderzoeksvragen. Opgemerkt moet worden dat deze onderzoeksvragen op de grens van de huidige onderzoeksmogelijkheden liggen. Het onderzoek is daarmee een verkennend onderzoek.

\subsection{Achtergrondinformatie}

Voor drie relevante onderwerpen wordt een kort overzicht van de wetenschappelijke literatuur geboden; de inzamelwijzen voor kunststofverpakkingsafval, de verschillen in kwaliteit tussen gerecyclede kunststoffen uit bron- en nascheiding en de analyse van moleculaire verontreiniging in gerecyclede kunststoffen.

\section{Inzamelwijzen kunststofverpakkingen in Europa}

Huishoudelijk kunststofverpakkingsafval wordt in Europa op diverse manieren ingezameld en gerecycled. De meest bekende methode is gescheiden inzameling (bronscheiding), waarbij het kunststofverpakkingsafval al bij het huishouden apart wordt gehouden van het restafval. Er zijn veel verschillende inzamelsystemen (haal-, breng- en combinatiesystemen) waarbij verschillende inzamelmiddelen worden gebruikt (zakken, ondergrondse en bovengrondse containers, kliko's, etc.). Omdat in de meeste Europese landen de hoeveelheid kunststofverpakkingsafval die per huishouden per week vrijkomt gering is, zijn de logistieke inzamelkosten relatief hoog en wordt het doorgaans gecombineerd gescheiden ingezameld met andere verpakkingen zoals drankenkartons, metaalverpakkingen etc. Hierdoor is er in Europa een veelvoud aan inzamelsystemen met uiteenlopende inzamelportfolio's ontstaan met allemaal verschillende namen: LWP, LVP, PMD, PMC, etc. In Nederland gebruiken we hiervoor de term 'bronscheiding'.

In veel Europese landen wordt kunststofverpakkingsafval niet alleen teruggewonnen door bronscheiding maar ook door nascheiding (Nederland, Duitsland, Oostenrijk, Spanje, Frankrijk, Italië, Cyprus, Noorwegen, Polen, Engeland etc.) [Burnley \& Coleman 2018; Cimpan et al. 2015; Jansen et al. 2013; Połomka \& Jędrczak 2019; Trulli et al. 2017]. Dit houdt in dat inzameling gebeurt samen met het restafval. Na inzameling worden de kunststofverpakkingen en vaak gelijktijdig ook de drankenkartons en de metalen machinaal uit het gemengde huishoudelijke restafval teruggewonnen. Doordat dit op veel verschillende manieren gebeurt is hier ook geen echte algemeen ingeburgerde term voor ontstaan. In Nederland wordt meestal de term nascheiding gebruikt. In andere landen worden omschrijvingen gebruikt: "Mechanisch Biologische Trennung", "central sorting of municipal solid waste", "mechanical recovery of plastic packages from municipal solid waste", "post separation", etc. Nascheiding wordt op veel verschillende manieren uitgevoerd in Europa; of het huisvuil wordt direct na inzameling gescheiden (dit is in Nederland gebruikelijk) of het wordt eerst biologisch gedroogd, gecomposteerd (Spanje), thermisch verwerkt (Polen) of enzymatisch gehydrolyseerd (Engeland) en daarna gescheiden. Ook de doelstelling van deze huisvuil-bewerking kan verschillen. In de meeste landen beoogt men recyclebare materialen af te scheiden (Nederland, Spanje), in andere landen wil men een brandstof (RDF, Refuse Derived Fuel) maken (Duitsland, Polen), in weer andere landen wil men het afval stabiliseren en het stortvolume beperken (Engeland). Door zowel de variatie in processen als in naamgeving als in doelstellingen, zijn deze activiteiten minder herkenbaar en minder breed bekend. 
Inzamelwijzen in Nederland en de effecten op de kwaliteit

Grofweg zijn er twee hoofd-inzamelroutes voor huishoudelijke kunststofverpakkingen in Nederland:

via gescheiden inzameling van voornamelijk PMD (bronscheiding) en via nascheiding uit huishoudelijk restafval. Het statiegeldsysteem wordt overigens in Nederland tot het bedrijfsmatige

kunststofverpakkingsafval gerekend en is hier dus buiten beschouwing gelaten. Beide inzamel- en recyclingsystemen hebben grofweg dezelfde structuur: 1) inzameling of terugwinning, 2) sorteren in dezelfde sorteerproducten en 3) mechanisch recyclen. Toch zijn er veel variaties in beide inzamelsystemen. Bij bronscheiding hanteren verschillende gemeenten verschillende systemen met uiteenlopende portfolio-breedtes (plastic, plastic + drankkartons, plastic + metalen + drankkartons), worden andere dragers (brengbak, haalzak en haalbak) gebruikt en zijn er andere inzamelfrequenties. Daarnaast zijn er verschillen in prikkels om het afval te scheiden. Voorbeelden zijn bijvoorbeeld het sturen door middel van verschillende inzamelfrequenties, verschillen in service op inzameling zoals omgekeerd inzamelen (herbruikbare grondstoffen worden aan huis opgehaald, restafval moet worden weggebracht) of het toepassen van tarifering op het aanbieden van ongescheiden restafval (diftar). Combinaties van deze systemen zijn ook mogelijk. Dit leidt in de praktijk tot een forse variatie in de kwaliteit van het brongescheiden ingezamelde kunststof materiaal [Leenaars \& de Boer, 2017].

Nascheiding wordt in Nederland in zes verschillende nascheidingsinstallaties uitgevoerd, die alle zes net iets anders zijn opgebouwd. Er kan geen eenvoudige vergelijking worden gemaakt tussen gerecyclede kunststoffen uit beide recyclingketens omdat er in beide ketens andere sorteer- en recyclingbedrijven betrokken zijn met net andere machines en instellingen. Wel zijn er testen gedaan in laboratoria met precies dezelfde sorteerprotocollen en recyclingapparatuur. Hieruit blijkt dat nagescheiden kunststofverpakkingen gemiddeld genomen meer belast zijn met organische vervuiling (aangehecht vuil) dan brongescheiden ingezamelde kunststoffen, dat de massarendementen van mechanische recycling dientengevolge lager zijn, maar dat de polymeerzuiverheden van de gewassen maalgoederen uit nascheiding juist iets hoger zijn dan die uit brongescheiden inzameling. De verklaring hiervoor is tweeledig. Ten eerste worden nagescheiden kunststoffen tweemaal door nabij infrarood spectroscopie (NIR) sorteerapparaten gesorteerd (bij nascheiding en bij sortering) en niet eenmaal zoals bij bronscheiding waardoor de kans op sorteerfouten iets kleiner wordt. Ten tweede, is de mechanische belasting bij nascheiding hoger (het materiaal wordt meer tegen elkaar aan geschuurd) waardoor verpakkingen meer componenten als labels en doppen verliezen en daarmee zuiverder worden. Overigens zijn de verschillen in polymere zuiverheid tussen gerecyclede kunststoffen uit bron- en nascheiding beperkt en is de vraag of dit beperkte verschil wel relevant is voor de eind-toepassingen [Thoden van Velzen et al. 2018].

Over de verschillen in deeltjesverontreiniging (verontreiniging met andere materialen en polymeren) tussen beide soorten gerecyclede kunststoffen is nog weinig bekend, te meer omdat dit lastig te onderzoeken is. De verwachting is dat deze deeltjesverontreiniging iets hoger is voor nagescheiden kunststoffen in vergelijking met brongescheiden kunststoffen. Voorlopige resultaten in rPET (gerecycled polyethyleen tereftalaat), waarin dit relatief eenvoudiger te meten is, wijzen in ieder geval die kant op. Wederom is hierbij de vraag of dit verschil betekenisvol is voor de eindgebruikers van het gerecyclede kunststof.

Daarnaast kunnen er in theorie ook verschillen in kleur en molecuulgewichtsverdeling bestaan tussen kunststoffen uit bron- en nascheiding. De kleur van de gerecyclede kunststoffen wordt echter hoofdzakelijk bepaald door de toegepaste kleurstoffen in de teruggewonnen verpakkingen en die verschilt niet tussen bron- en nascheiding.

Het gemiddelde molecuulgewicht en de molecuulgewichtsverdeling bepalen in grote mate de verwerkbaarheid van de gerecyclede kunststoffen, of het materiaal geschikt is voor blaas- of spuitgiettoepassingen etc. Deze wordt beïnvloed door ketenlengtes van de polymeren die in het verpakkingsafval aanwezig zijn en door de mate van degradatie van het materiaal tijdens gebruik en recycling. Aangezien verpakkingskunststoffen slechts kort gebruikt worden is in het algemeen de degradatie beperkt en zijn de soorten verpakkingen die in het brongescheiden of nagescheiden materiaal aanwezig zijn leidend. Deze verschillen nauwelijks, dus zal de verwerkbaarheid van de gerecyclede kunststoffen ook niet of nauwelijks verschillen. 
Dan resteert nog een eventueel verschil in moleculaire verontreiniging. Dit zijn losse moleculen die zijn geabsorbeerd in het gerecyclede kunststof. Vaak zijn dit moleculen met beperkte molecuulmassa's waardoor ze vaak vluchtig zijn en toxicologisch relevant kunnen zijn. De meest bekende uiting van deze vorm van verontreiniging is geur. Een minder bekende uitingsvorm is de migratie van moleculen. Dit laatste moet bepaald worden als men een kunststofverpakking wil gebruiken voor het verpakken van levensmiddelen. Tot nu toe zijn van de gerecyclede kunststoffen bijna uitsluitend rPET kwaliteiten ${ }^{3}$ voorlopig goedgekeurd voor de toepassing in levensmiddelverpakkingen, omdat dit kunststof sowieso al weinig moleculen absorbeert en dan kunnen ze ook nog eens relatief makkelijk eruit verwijderd worden met nacondensatie-technologie [Welle, 2011]. Tot nu toe is het effect van de inzamelwijze op de moleculaire verontreiniging in gerecyclede kunststoffen niet onderzocht. Daarmee is dit onderzoek nieuw en verkennend.

\section{Moleculaire verontreiniging in gerecyclede kunststoffen}

Het is al langer bekend dat kunststoffen (zowel nieuw oftewel virgin als gerecycled) een geur hebben en dat er in migratie-experimenten moleculaire migranten worden aangetroffen en bepaald. De belangrijkste migranten uit virgin kunststoffen zijn bepaald als onderdeel van de toelatingsprocedure voor levensmiddelverpakkingen [EU 2011/10]. In veel gevallen is het echter beperkt bekend welke moleculen de geur van virgin kunststof vormen [Robertson, 2012]. Over de geur van gerecyclede kunststoffen is zelfs nog minder bekend. Wel zijn er in de afgelopen jaren enkele verkennende bijdragen over geschreven, deze worden hieronder toegelicht.

In 2001 publiceerde een Zweedse onderzoeksgroep een verkenning van de organische moleculen die in virgin hogedichtheidpolyetheen (HDPE) en polypropeen (PP) kunststof worden aangetroffen en in verpakkingen die uit het huisvuil zijn afgescheiden van dezelfde kunststofsoorten [Camacho \& Karlsson, 2001]. De kunststoffen werden onder verhitting geëxtraheerd met organische oplosmiddelen en de extracten werden onderzocht met gaschromatografie waaraan een massaspectrometer is gekoppeld (GC-MS). De gaschromatogrammen van zowel virgin HDPE als PP laten een zeer regelmatig patroon zien waarin verzadigde koolwaterstoffen en de varianten met een onverzadigheid domineren en nog enkele kleine pieken aanwezig waren die onder andere als alcoholen en ketonen konden worden geïdentificeerd. De gaschromatogrammen van de gerecyclede kunststoffen lieten dezelfde dominante patronen van alkanen en alkenen zien, maar daar bovenop waren veel andere kleine piekjes te zien. In het gaschromatogram van gerecycled HDPE waren ook bekende geurstoffen (3-careen, $\beta$-myrceen, limoneen, terpinoleen) en een hele reeks esters, alcoholen en andere verbindingen te zien. In het gaschromatogram van gerecycled PP waren meer alkanen en alkenen te zien maar ook een reeks aan verschillende organische verbindingen.

Tussen 2017 en 2019 publiceerde een Duitse onderzoeksgroep een reeks van drie artikelen over het voorkomen van moleculaire verontreiniging in kunststofverpakkingsafval, de bijbehorende geur en de effectiviteit van ontgeuringsmaatregelen. De verkenning in 2017 onderzocht de moleculen die kunnen worden aangetroffen in gewassen gemengd kunststofverpakkingsafval uit Duitse brongescheiden inzameling, alsmede hun geurintensiteit. Het gepubliceerde gaschromatogram laat enorm veel pieken zien die grotendeels overlappen, daar bovenop werden 32 moleculen met een hoge geurintensiteit geïdentificeerd. De geurintensiteit wordt aangeduid met verdunningsfactoren waarbij de geur wegvalt. Geurstoffen met de hoogste geurintensiteit (verdunningsfactor) waren uiteenlopend van microbiologische afbraakproducten (2-methyl-isoborneol, trichlooranisool), tot chemicaliën ( $p$-cresol) tot bekende geurstoffen (Patchouli alcohol, rotundon, 4-(4'-hydroxyfenyl)butaan-2-on, etc.). Dit maakt het waarschijnlijk dat een deel van de geurstoffen afkomstig zijn van productresten en een deel afkomstig is van de microbiologische flora die productrestanten metaboliseert in zeer krachtig geurende stoffen. De reeksen aan alkanen en alkenen die dominant in de gaschromatogrammen worden waargenomen hebben zeer lage verdunningsfactoren en zijn dus nauwelijks geuractief [Strangl et al., 2017].

${ }^{3}$ Het betreft hier zowel rPET gemaakt van drankflessen uit statiegeldsystemen van bv. Nederland, Duitsland, Denemarken etc, maar ook rPET gemaakt van drankflessen uit bronscheidingsystemen van bv. Zwitserland, Oostenrijk, België, Frankrijk, Spanje en Italië. 
In het artikel van 2018 werd dieper ingegaan op het verschil tussen virgin HDPE en gerecycled HDPE uit brongescheiden Duitse inzameling, zowel als gewassen maalgoed als geëxtrudeerd granulaat. Het gewassen maalgoed ruikt veel sterker dan het virgin HDPE. Deze geur wordt als onaangenaam beoordeeld en door extrusie (zonder vacumering of stripping) neemt deze geur maar weinig af. Er werden 32 geur-actieve verbindingen geïdentificeerd in het gerecyclede HDPE. Hiervan hadden de hoogste verdunningsfactoren (in volgorde van retentietijd): tetrahydrolinalool, linalool, boterzuur, $a$-damascon, $a$-isomethyl-jonon, verdyl-acetaat, $\beta$-jonon, verdyl propaanoaat, $\gamma$-decalacton, sotolon, rotundon, vanilline en 4 -(4'-hydroxyfenyl)butaan-2-on. Hiervan zijn boterzuur en $\beta$-jonon microbiologische omzettingsproducten, de rest van deze meest geur-actieve verbindingen zijn allemaal bekende geurstoffen die worden toegepast in cosmeticaproducten, schoonmaakproducten, etc. [Strangl et al., 2018]. In het aansluitende artikel uit 2019 wordt de efficiëntie van vacuümontgeuringstechnologie bestudeerd op granulaat van gerecycled HDPE (commercieel toegepaste decontaminatie-reactor met roerwerk, verhitting en vacuüm, helaas zijn de procesomstandigheden niet gedefinieerd). Hieruit blijkt dat de concentratie van individuele verbindingen sterk afneemt met afnames van tussen de 50 en $99 \%$ (op basis van piekoppervlakken in het gaschromatogram). De concentratiereducties waren $85-99 \%$ voor geabsorbeerde geurstoffen en slechts 50-60\% voor afbraakproducten van HDPE (octanal en E-oct-2-eenal). Helaas geldt deze afname niet in gelijke mate voor de geuractiviteit van deze verbindingen. Geurstoffen met lage verdunningsfactoren verdwijnen nog wel na enkele uren grotendeels (azijnzuur, boterzuur, etc.). De meest geur-actieve moleculen kunnen echter onvoldoende worden verwijderd (het piekoppervlak wordt duidelijk kleiner maar de verdunningsfactor blijft of gelijk of wordt beperkt kleiner). Zelfs na 7 uur behandeling zijn de meeste van deze geur-actieve verbindingen nog steeds prominent aanwezig in het geurprofiel en dus nauwelijks verminderd [Strangl et al., 2019].

\subsection{Opbouw van dit rapport}

Vanwege de structuur van de onderzoeksvragen met de vier onderzoekstaken is er in dit rapport voor gekozen om na een algemeen deel over generieke onderzoeksmethoden de vier taken apart te beschrijven. Zodoende worden zowel methodische aspecten als resultaten en een deelconclusie per taak in separate hoofdstukken behandeld. 


\section{Generieke onderzoeksmethoden}

Voor de verschillende taken in dit project is een aantal generieke onderzoeksmethoden gebruikt, welke in dit hoofdstuk worden beschreven. Taak specifieke onderzoeksmethoden zijn beschreven bij de desbetreffende taak.

\subsection{Monster opslag en transport}

Om verontreiniging tijdens de opslag en het transport van de monsters te voorkomen zijn de monsters gekoeld $\left(4^{\circ} \mathrm{C}\right)$ opgeslagen en getransporteerd in een gesealde geurdichte aluminium zak. De bronscheiding en nascheiding monsters zijn opgeslagen in verschillende koelcellen, om onderling contact te voorkomen. Verder is zo schoon mogelijk gewerkt, altijd met handschoenen, en is het materiaal zo min mogelijk in contact geweest met de buitenwereld. Apparatuur is extra schoongemaakt met een neutraal (niet geurend) schoonmaakmiddel, in het bijzonder tussen verwerking van bron- en nascheiding materiaal

\subsection{Hexaanextractie}

Door middel van hexaanextractie worden alle vetoplosbare bestanddelen uit het LDPE-folie geëxtraheerd. Deze bestanddelen kunnen bestaan uit i) kunststof-degradatie-oligomeren (afbraakproducten van het kunststof nadat het bijvoorbeeld te lang in de zon heeft gelegen, het kunststof te warm is geworden etc.), ii) toegevoegde additieven, iii) componenten uit de bedrukking (drukinkt) en iv) geurstoffen.

Voor de hexaanextractie is een parallel soxhlet opstelling gebruikt (RH 254, Behr Labor Technik). Een $250 \mathrm{~mL}$ rondbodemkolf is gevuld met $200 \mathrm{~mL} n$-hexaan. Hier bovenop is een $100 \mathrm{~mL}$ soxhletextractor geplaatst met daarin de LDPE-folie (10 g, in stukken geknipt) in een cellulose extractiehuls. De soxhletextratie is vervolgens gestart door het verhitten van de hexaan. Na 5-6 uur is de extractie gestopt. De rondbodemkolf met het extract is, na verwijderen van de hexaan, gedroogd in een oven van $105{ }^{\circ} \mathrm{C}$ voor 30 min en vervolgens is het gewicht van het extract bepaald. Alle hexaanextracties zijn uitgevoerd in duplo.

\subsection{Infrarood spectroscopie}

Met infrarood spectroscopie kan de aanwezigheid van chemische functionele groepen gemeten worden. Infrarood spectra zijn genomen op een ALPHA II (Bruker, Duitsland) ATR-FTIR (Attenuated Total Reflectance Fourier Transform Infrared Spectroscopy) uitgerust met een diamant kristal. De folie en/of het extract zijn zonder verdere monstervoorbereiding gemeten door het te meten materiaal tegen het kristal te klemmen. Alle spectra zijn gemiddeld over 64 scans met een resolutie van $4 \mathrm{~cm}^{-1}$. Voor de meting is een achtergrond spectrum genomen.

\subsection{Screening voor vluchtige stoffen}

Een nauwkeurige analyse methode om kleine concentraties vluchtige stoffen (stoffen met een moleculaire massa tot ongeveer $200 \mathrm{~g} / \mathrm{mol}$; dit zijn mogelijke geurstoffen) te kunnen aantonen is GC-MS. De screening voor vluchtige stoffen is uitgevoerd door het Fraunhofer-Institut fur Verfahrenstechnik und Verpackung onder verantwoording van Dr. Frank Welle en Petra Schmid. Hieronder is de methode zoals gerapporteerd door het Fraunhofer-Institut gegeven. Alle metingen zijn in drievoud uitgevoerd. 
De geaccrediteerde onderzoeksmethode 1.334 (09:2019) van het Fraunhofer IVV instituut werd gebruikt. $1.0 \mathrm{~g}$ van het monstermateriaal werd in een vial (glazen potje met schroefdeksel en septum voor kopruimte GC gebracht. Nadat de monsters op temperatuur zijn gebracht werden ze met gaschromatografie en een vlamionisatiedetector (GC/FID) geanalyseerd. De gebruikte gaschromatograaf was een Perkin Elmer AutoSystem XL, de kolom was van een DB 1 van $30 \mathrm{~m}$, $0.25 \mathrm{~mm}$ interne diameter en $0.25 \mu \mathrm{m}$ film dikte. Het temperatuurprogramma was: $50{ }^{\circ} \mathrm{C}(4 \mathrm{~min})$, opwarmsnelheid $20^{\circ} \mathrm{C} / \mathrm{min}, 320^{\circ} \mathrm{C}$ (15 min). De doorvoerdruk was $50 \mathrm{kPa}$ helium met een split van $10 \mathrm{ml} / \mathrm{min}$. De kopruimte autosampler was een Perkin Elmer HS $40 \mathrm{XL}$. De oven temperatuur was $120^{\circ} \mathrm{C}$, de naald temperatuur was $130^{\circ} \mathrm{C}$ en van de overdrachtsbuis $140^{\circ} \mathrm{C}$. de evenwichtstijd was 1 uur. Binnen 3 minuten werd het monster op druk gebracht. De injectietijd was 0.02 min en de terugtrektijd was $1 \mathrm{~min}$. De identificatie en karakterisering werd uitgevoerd door de kopruimte gaschromatograaf te koppelen aan een massaspectrometer.

\subsection{Screening voor gemiddeld tot niet vluchtige stoffen}

Naast een analyse van de vluchtige stoffen zijn ook de aanwezige gemiddeld tot niet vluchtige moleculaire verontreinigingen geanalyseerd voor alle monsters. Dit zijn stoffen met een moleculaire massa van $150-750 \mathrm{~g} / \mathrm{mol}$. De screening voor minder vluchtige en niet vluchtige verbindingen is uitgevoerd door het Fraunhofer-Institut fur Verfahrenstechnik und Verpackung onder verantwoording van Dr. Frank Welle en Petra Schmid. Hieronder is de methode zoals gerapporteerd door het Fraunhofer-Institut gegeven. Alle metingen zijn in drievoud uitgevoerd.

De geaccrediteerde onderzoeksmethode 1.337 (02:2018) van het Fraunhofer IVV instituut werd gebruikt. Van elk monster werd $1.0 \mathrm{~g}$ onder gedompeld in $10 \mathrm{ml}$ dichloormethaan en opgeslagen voor 3 dagen bij $40{ }^{\circ} \mathrm{C}$. Vervolgens werden de extracten geanalyseerd met zowel gaschromatografie (GC/FID) als gaschromatografie gekoppeld met massaspectrometrie (GC-MS). De gaschromatograaf was een Agilent 6890, de kolom: DB 1, de lengte $30 \mathrm{~m}$, de interne diameter $0.25 \mathrm{~mm}$ en de filmdikte $0.25 \mu \mathrm{m}$. Het doorlopen temperatuurprogramma: $50^{\circ} \mathrm{C}(2 \mathrm{~min})$, gevolgd door opwarmen naar $340^{\circ} \mathrm{C}$ met een opwarmsnelheid van $10^{\circ} \mathrm{C} / \mathrm{min}$ en tenslotte $15 \mathrm{~min}$ bij deze eindtemperatuur. De voordruk was $50 \mathrm{kPa}$ waterstof met een split van $10 \mathrm{ml} / \mathrm{min}$. Butylhydroxyanisool (BHA) and Tinuvin 234 werden gebruikt als interne standaarden. Identificatie en karakterisering volgde uit het koppelen van gaschromatograaf aan de massaspectrometer. Hiervoor was de gaschromatograaf een ThermoQuest SSQ, kolom: DB $1 \mathrm{MS}$ - $30 \mathrm{~m}$ lengte, $0.25 \mathrm{~mm}$ interne diameter, $0.25 \mu \mathrm{m}$ film dikte en een temperatuur programma van: $80^{\circ} \mathrm{C}(2 \mathrm{~min})$, gevolgd door opwarmen met $10^{\circ} \mathrm{C} / \mathrm{min}$ tot $340{ }^{\circ} \mathrm{C}$ (30 min). Er werd een volledige scan gemaakt van massa's tussen de m/z 40 en 800 . De massaspectra die werden verkregen werden geïdentificeerd aan de hand van de spectra in de NIST bibliotheek.

\subsection{Geurpanelanalyse}

De geurpanelanalyse is uitgevoerd door het Fraunhofer-Institut fur Verfahrenstechnik und Verpackung onder verantwoording van Dr. Frank Welle en Petra Schmid. Hieronder is de methode zoals gerapporteerd door het Fraunhofer-Institut gegeven.

De door het Fraunhofer instituut gebruikte methode is nog in ontwikkeling en derhalve nog niet geaccrediteerd. De analyses zijn gebaseerd op de geurpanelmethode DIN/ISO 10967, deel 1 . Het Fraunhofer IVV geurpanel bestond uit acht getrainde panelleden ( 7 vrouwelijke en 1 mannelijke deelnemers, allemaal tussen de 25 en de 57 jaar oud). Om betekenisvolle gegevens te verkrijgen werden de panelleden gekalibreerd door middel van interne groepsdiscussies waarbij de belangrijkste omschrijvingen van de monsters worden vastgesteld en gedefinieerd ten opzichte van bekende geuren, referentiegeurstoffen of aroma-oplossingen. Nadat de panelleden zijn gekalibreerd wordt de intensiteit van elke geur-omschrijving beoordeeld voor elk monster aan de hand van visueel analoge schalen. In de eerste sessie wordt elk panellid gevraagd om de geur te beschrijven in eigen woorden. De geur-omschrijvingen en de bijbehorende definities worden besproken in de tweede trainingssessie, 
gericht op het verkrijgen van een attributenlijst, die door alle panelleden op gelijke wijze wordt begrepen, zie Tabel 1 en Tabel 2. Bovendien werd het panel gekalibreerd naar de schaal, waarbij het minimum en het maximum voor elk attribuut werd vastgesteld langs de visueel analoge schaal van 0 (niet waarneembaar) tot 100 (zeer intens). De analyses werden uitgevoerd in individuele sensorische studieruimtes onder gestandaardiseerde omstandigheden. De monsters werden geserveerd in gecodeerde glazen potjes bij kamertemperatuur in een willekeurige volgorde. De gegevens werden

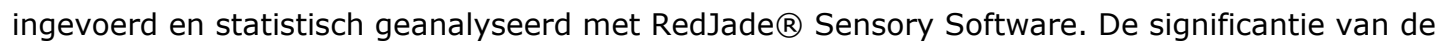
attributen uit de beschrijvende analyse werden beoordeeld met de ANOVA en Duncan-testen ( $p$ waarde van 0,05$)$.

Tabel 1 Geselecteerde geureigenschappen en bijbehorende referentiestoffen gebruikt voor de geurprofielanalyses in taak $1 b$.

\begin{tabular}{ll} 
Geureigenschap & Referentie \\
Zeepachtig, wasmiddelachtig & Decanal \\
\hline Kaasachtig, zweetachtig & Boterzuur \\
\hline Aards, muf & Geosmine \\
\hline Ranzig nootachtig & Ranzige hazelnoot nougatine \\
\hline Metaalachtig & Trans-4,5-epoxy-(E)-2-decenal \\
\hline
\end{tabular}

Tabel 2 Geselecteerde geureigenschappen en bijbehorende referentiestoffen gebruikt voor de geurprofielanalyses in taak 2.

\begin{tabular}{ll} 
Geureigenschap & Referentie \\
Verbrand (sigarettenrook, asbak, houtskool) & Zonder referentie \\
\hline Fenolisch, inktachtig & Fenol \\
\hline Zeepachtig, wasmiddelachtig & Decanal \\
\hline Gerookte ham & Guaiacol \\
\hline Ranzig nootachtig & Ranzige hazelnoot nougatine \\
\hline Waxachtig, paraffineachtig & Zonder referentie \\
\hline Aards, muf & Geosmine \\
\hline Fruitig, amandel & Acetofenon \\
\hline
\end{tabular}

\subsection{Mechanische recycling}

De foliemonsters werden mechanisch gerecycled volgens het onderstaande protocol dat is opgesteld om een standaard recyclingproces in het laboratorium na te bootsen. Alle apparaten werden tussen de monsters gereinigd om kruisvervuiling te voorkomen. Eerst werden alle monsters uit nascheiding gerecycled, daarna werden alle apparaten extra grondig schoongemaakt, gedroogd en vervolgens werden alle monsters uit bronscheiding gerecycled.

De volgende stappen werden doorlopen tijdens het recyclingproces.

1. Het folie-monster werd volledig gemalen tot $1-3 \mathrm{~cm}$ snippers met behulp van een WEIMA WLK-04 maalmolen met een $35 \mathrm{~mm}$ plaat.

2. Meten van het vochtgehalte van monsters van het vieze maalgoed in drievoud, gebruik makend van een oven $\left(105^{\circ} \mathrm{C}\right.$, overnacht) en weegschaal.

3. Afwegen van $2.5 \mathrm{~kg}$ vies maalgoed en hiermee de wasmolen vullen.

4. Spoelen/voor-wassen van de snippers met 150 liter koud water. Alle afvoerwater wordt gezeefd om het slib op te vangen met drie roosters. Het slib wordt overnacht gedroogd in een oven.

5. Hoofdwas (water temperatuur en detergent afhankelijk van de taak). Wederom wordt bij het uit laten stromen van het gebruikte waswater slib opgevangen met slibroosters. Dit wordt overnacht gedroogd in de oven.

6. Indien hoofdwas met een detergent: snippers afspoelen tot het afvalwater een pH waarde heeft van lager dan 8.0. Wederom wordt bij het uit laten stromen van het gebruikte waswater slib opgevangen met slibroosters. Dit wordt overnacht gedroogd in de oven.

7. Hierna wordt het gewassen en natte maalgoed op dichtheid gescheiden met een hoge waterkolom met daarin 300 liter water, onderin een zinksluis en bovenin een afschepmogelijkheid voor het drijfgoed. Het natte drijfgoed en natte zinkgoed wordt apart opgevangen. 
8. Beide producten worden mechanisch gedroogd met een mandcentrifuge gedurende 2 minuten op 2000 tpm.

9. Vervolgens worden beide producten overnacht gedroogd in een oven op $105^{\circ} \mathrm{C}$ en daarna gewichten van het hoofdproduct (drijf-fractie), bijproduct (zink-fractie) en afval (slib) meten.

10. Tenslotte wordt het droge drijfgoed eerst in een oven bij $180^{\circ} \mathrm{C}$ gecompacteerd tot een gesmolten plak, die vervolgens werd fijn gemalen met een Wanner compact maalmolen C $17.26 \mathrm{sv}$ en $8 \mathrm{~mm}$ zeef plaat.

De massabalans van het mechanische recycling proces is berekend met behulp van bovenstaande gewichten [Thoden van Velzen et al. 2016]. 


\section{Taak 1: Verschil in moleculaire verontreiniging tussen gerecyclede kunst- stoffolies uit bronscheiding en nascheiding}

Deze taak onderzoekt het verschil in moleculaire verontreiniging tussen gerecyclede kunststoffolies uit gescheiden inzameling van PMD (bronscheiding) en uit nascheiding. Dit verschil is echter lastig te bepalen omdat er meerdere gerecyclede kunststoffen worden gemaakt (PET flessen, PET schalen, PE, $\mathrm{PP}$, film en Mix), omdat er meerdere sorteer- en recyclingprocessen in de praktijk worden uitgevoerd, en omdat er forse variatie kan ontstaan tussen verschillende monsters van hetzelfde systeem.

Voor deze taak is gekozen om de analyse te beperken tot het sorteerproduct film (DKR-310 ${ }^{4}$ ). Dit bestaat hoofdzakelijk uit lagedichtheidpolyetheen (LDPE) folie-materiaal, waarvan bekend is dat het relatief veel moleculaire verontreiniging opneemt, en dus fungeert als worst-case-scenario. Voorbeelden van producten gemaakt uit LDPE-folie zijn draagtassen, WC-papier verpakkingen of broodzakken.

Taak 1 is opgedeeld in twee subtaken; in taak 1a wordt de moleculaire verontreiniging van één specifiek product genomen uit een monster vergeleken (om verschillen tussen materialen zoveel mogelijk uit te sluiten), terwijl in taak $1 \mathrm{~b}$ de moleculaire verontreiniging van een groter deel van het monster wordt geanalyseerd.

\subsection{Onderzoeksmethode}

Monsters van het sorteerproduct DKR-310 zijn op drie verschillende dagen genomen bij Suez Rotterdam (dat brongescheiden materiaal verwerkt) en AVR Rotterdam (dat nagescheiden materiaal verwerkt). Het gaat om materiaal dat op de bewuste dag werd verwerkt in de installatie. Het is daarmee niet bekend wanneer het materiaal exact is ingezameld. Een overzicht van alle monsters uit taak 1 is weergegeven in Tabel 3. De monsters zijn gecodeerd met de letter ' $B$ ' of ' $N$ ' voor respectievelijk bronscheiding en nascheiding, gevolgd door een nummer dat de desbetreffende monsternamedag weergeeft (' 1 ' voor de eerste monsternamedag, ' 2 ' voor de tweede etc.).

Tabel $3 \quad$ Overzicht van de monsters genomen voor taak 1.

\begin{tabular}{llll} 
Monster & Monsternamedag & Herkomst & Bron- / nascheiding \\
B1 & 6 augustus 2019 & Suez Rotterdam & Bron \\
\hline N1 & 6 augustus 2019 & AVR Rotterdam & $\mathrm{Na}$ \\
\hline B2 & 13 augustus 2019 & Suez Rotterdam & Bron \\
N2 & 13 augustus 2019 & AVR Rotterdam & $\mathrm{Na}$ \\
\hline B3 & 3 september 2019 & Suez Rotterdam & Bron \\
\hline N3 & 3 september 2019 & AVR Rotterdam & $\mathrm{Na}$ \\
\hline
\end{tabular}

\subsubsection{Taak $1 \mathrm{a}$}

Uit elk monster is hetzelfde type veelvoorkomend LDPE-folie product (Albert Heijn draagtas) geselecteerd, gewassen met een basiswas (afborstelen met koud water) en geanalyseerd. Er is voor de Albert Heijn tas gekozen omdat dit product als enige in voldoende grote hoeveelheden in zowel de monsters afkomstig van bron- als nascheiding voorkwam. Echter moet wel worden opgemerkt dat een draagtas een heel andere gebruiksgeschiedenis heeft dan een verpakking voor eenmalig gebruik. Vaak worden draagtassen voor een langere tijd gebruikt, wat effect kan hebben op de hoeveelheid

\footnotetext{
${ }^{4}$ DKR specificaties zijn standaarden voor de kwaliteit en zuiverheid van sorteerproducten, opgesteld door DKR, zie https://www.gruener-punkt.de/de/downloads.html
} 
moleculaire verontreiniging in dit product. Aangezien deze studie een worst-case scenario onderzoekt, wordt dit langere gebruik voor dit onderzoek niet als een belemmering gezien door de auteurs.

Waar mogelijk zijn zo veel mogelijk de onbedrukte (witte) stukken van de draagtas geselecteerd voor alle analyses. Echter bevatten alle monsters stukken bedrukte (blauwe opdruk) draagtassen. In de monsters afkomstig uit bronscheiding was het lastig om voldoende materiaal te vinden en zit relatief meer van het bedrukte materiaal; mogelijk zien we dit terug in de resultaten.

\subsubsection{Taak 1b}

Van alle 6 monsters uit Tabel 3 ( 3 bronscheiding en 3 nascheiding) is een monster genomen van circa 2.5 à $5 \mathrm{~kg}$. Om het materiaal zo min mogelijk aan te raken (en daarmee te beïnvloeden) is het niet verder gesorteerd, wat in principe wel gebruikelijk is ter voorbereiding van een mechanisch recycling proces. Wel zijn opvallende materialen die niet in een foliemonster thuis horen en de verwerking mogelijk gaan verstoren, handmatig uit het monster verwijderd, bijvoorbeeld blikjes en hout. Vervolgens zijn de 6 monsters mechanisch gerecycled volgens het protocol als beschreven in paragraaf 2.7 Mechanische recycling.

\subsection{Resultaten en discussie}

Taak 1 is opgesplitst in twee subtaken, echter zijn beide taken gebaseerd op dezelfde monsters van het sorteerproduct DKR-310. In taak $1 \mathrm{a}$ is uit deze monsters een veelvoorkomend folie gesorteerd, in dit geval is er gekozen voor een Albert Heijn draagtas. Door de keuze van een specifiek product wordt het effect van het type folie uitgesloten. In taak $1 \mathrm{~b}$, daarentegen, is er juist een willekeurig monster van circa drie kilogram uit het sorteerproduct genomen om zo een beter gemiddelde te verkrijgen en eventuele uitschieters te minimaliseren.

\subsubsection{Moleculaire verontreiniging in Albert Heijn tassen (Taak 1a)}

Figuur 1 geeft foto's weer van de Albert Heijn draagtassen geselecteerd uit het monster van de eerste monsternamedag voor en na een basiswas (monsters B1 en N1). Voor zowel monster B1 als N1 neemt de hoeveelheid zichtbaar aangehecht vuil, zoals zand, slib, etc., significant af na deze basiswas. Er is weinig tot geen verschil tussen de hoeveelheid zichtbaar vuil voor de draagtassen uit de bron- en nascheiding. Het valt wel op dat er binnen een monster lichte variatie in de hoeveelheid zichtbaar vuil zit, daarom zijn voor alle analyses de stukken kleiner geknipt en gemengd voor analyse. 

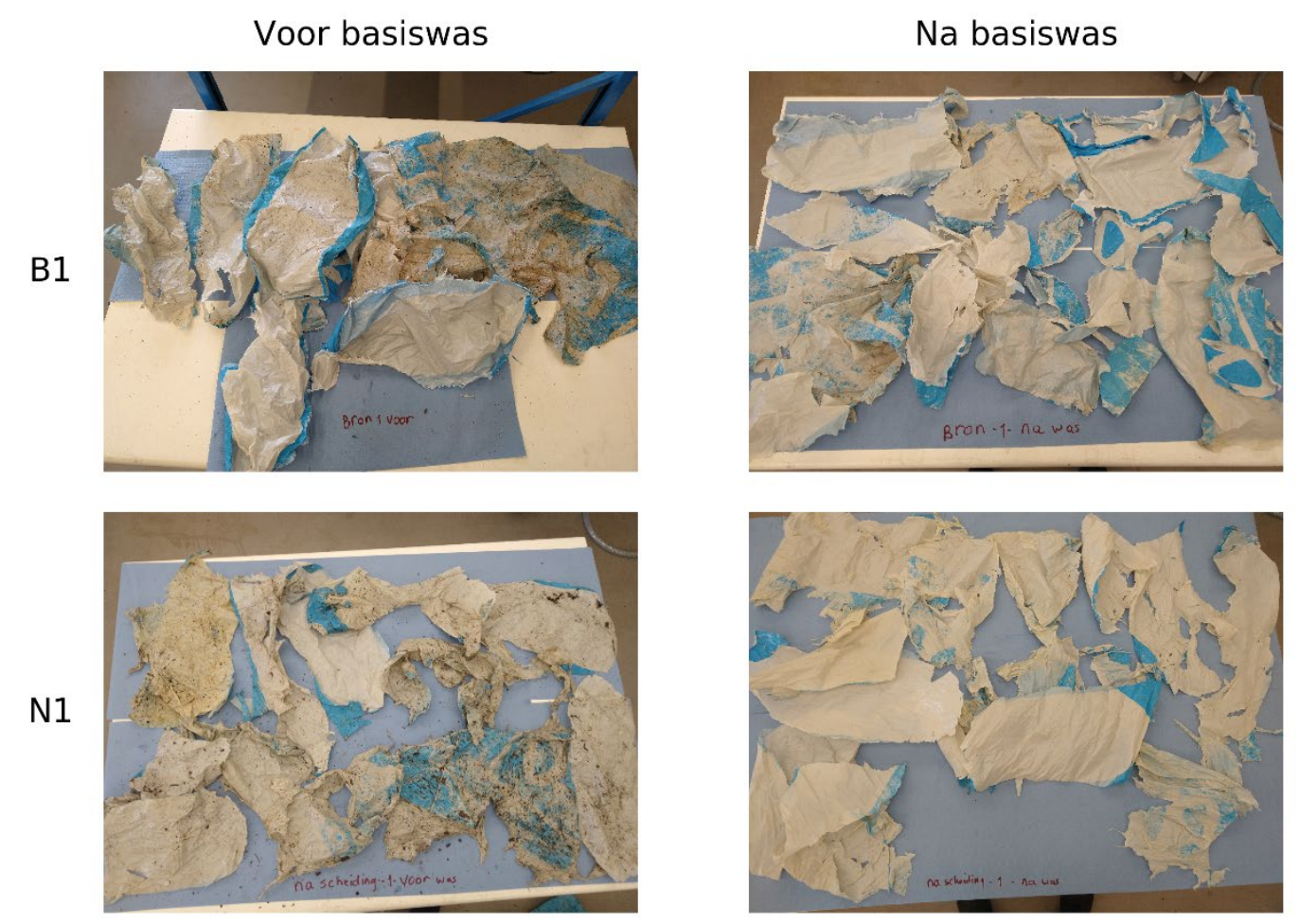

\section{Figuur 1 Foto's van de Albert Heijn draagtassen genomen voor en na de basiswas op de eerste bemonsterdag voor zowel bron- (boven) als nascheiding (onder)}

Door middel van hexaanextractie worden alle vetoplosbare bestanddelen uit het LDPE-folie geëxtraheerd. Deze bestanddelen kunnen bestaan uit i) kunststof-degradatie-oligomeren (afbraakproducten van het kunststof nadat het bijvoorbeeld te lang in de zon heeft gelegen, het kunststof te warm is geworden etc.), ii) toegevoegde additieven, iii) componenten uit de bedrukking (drukinkt) en iv) geurstoffen. In dit project is er interesse in de hoeveelheid geurstoffen in het kunststof.

Figuur 2 geeft het geëxtraheerde gehalte van vetoplosbare bestanddelen weer voor zowel de folie afkomstig uit bronscheiding als uit nascheiding. Het valt op dat voor beide verwerkingsprocessen er een grote spreiding in het geëxtraheerde gehalte te vinden is afhankelijk van de bemonsterdag. Dit is een indicatie dat ook de verontreiniging sterk verschilt per bemonsterdag, echter kan men hieruit niet concluderen wat de aard van de verontreiniging is en of deze invloed heeft op het recyclaat. Er is geen significant verschil gevonden in het geëxtraheerde gehalte van vetoplosbare bestanddelen voor bronversus nascheiding.

Het valt op dat de hoeveelheid verontreiniging door afbraakproducten, additieven en bedrukking al in de orde grootte van enkele procenten ligt. De verwachte concentratie van de geurstoffen (moleculaire verontreiniging) ligt echter veel lager, waarschijnlijk in de orde van ppm's (part per million, delen per miljoen) waardoor deze niet meetbaar zijn met hexaanextractie. 

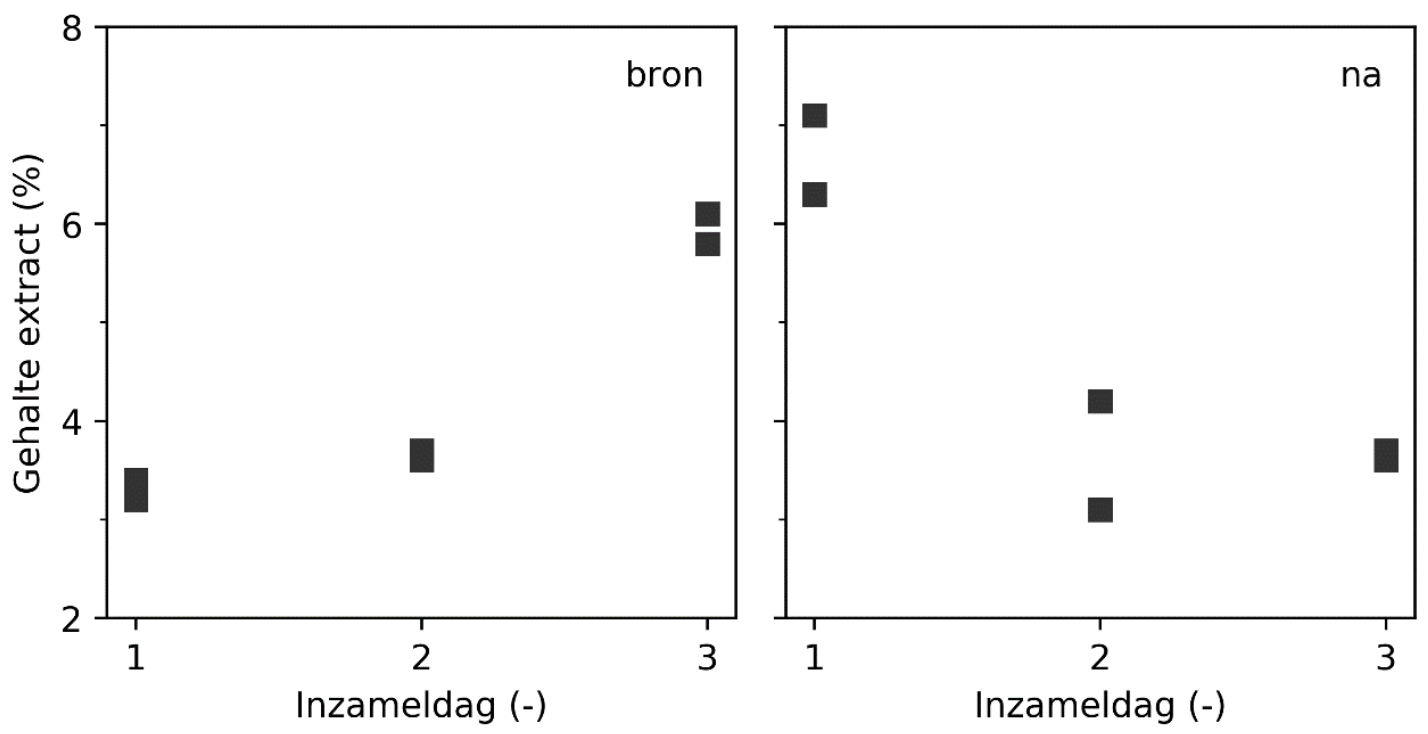

Figuur 2 Resultaten van de hexaanextractie voor Albert Heijn tassen uit bronscheiding (links) en nascheiding (rechts). Alle extractie gehaltes zijn in duplo bepaald

Met infrarood spectroscopie kan de aanwezigheid van chemische functionele groepen gemeten worden. Het is een zogenaamde oppervlakte techniek, waarbij met de gebruikte apparatuur de chemische groepen tot een diepte van $\sim 1.66 \mu \mathrm{m}$ in het materiaal gemeten kunnen worden. Figuur 3 laat representatieve spectra zien voor alle monsters uit taak 1 . De grijs gearceerde gebieden geven de positie weer waar ook signalen afkomstig van de blauwe drukinkt zijn aangetroffen. Zie Figuur 21 in Bijlage 1 voor de bepaling van deze grijze gebieden. Variatie in signalen in deze grijs gearceerde gebieden kan dus zowel worden veroorzaakt door de drukinkt alsmede de aanwezigheid van verontreinigingen.

Er is geen hexaanextractie en infrarood analyse van een nieuwe Albert Heijn tas uitgevoerd, waardoor deze resultaten alleen ten opzichte van de overige monsters te vergelijken zijn. Het infrarood spectrum van monster B1 laat bovengemiddeld grote pieken bij $1575 \mathrm{~cm}^{-1}$ en $1540 \mathrm{~cm}^{-1}$ zien ten opzichte van de overige monsters. Dit golfgetal is typisch voor stoffen die een nitrogroep ( $\mathrm{N}-\mathrm{O})$, of een alkeen functionaliteit $(\mathrm{C}=\mathrm{C})$ bevatten. Opvallend is dat deze signalen nagenoeg niet zijn aangetroffen in het extract, en dat dus de corresponderende stof niet oplosbaar is in hexaan.

Monster N1 bevat een signaal bij $1750 \mathrm{~cm}^{-1}$ die nagenoeg niet aanwezig is in de andere monsters. Signalen in deze regio behoren tot een carbonyl functionaliteit $(\mathrm{C}=\mathrm{O})$ aanwezig in onder andere vetzuren en esters. Deze carbonyl piek is niet gevonden in het residu, waardoor er geconcludeerd kan worden dat de corresponderende stof oplosbaar is in hexaan. Dit kan het hogere geëxtraheerde gehalte gemeten bij de hexaanextractie verklaren. 

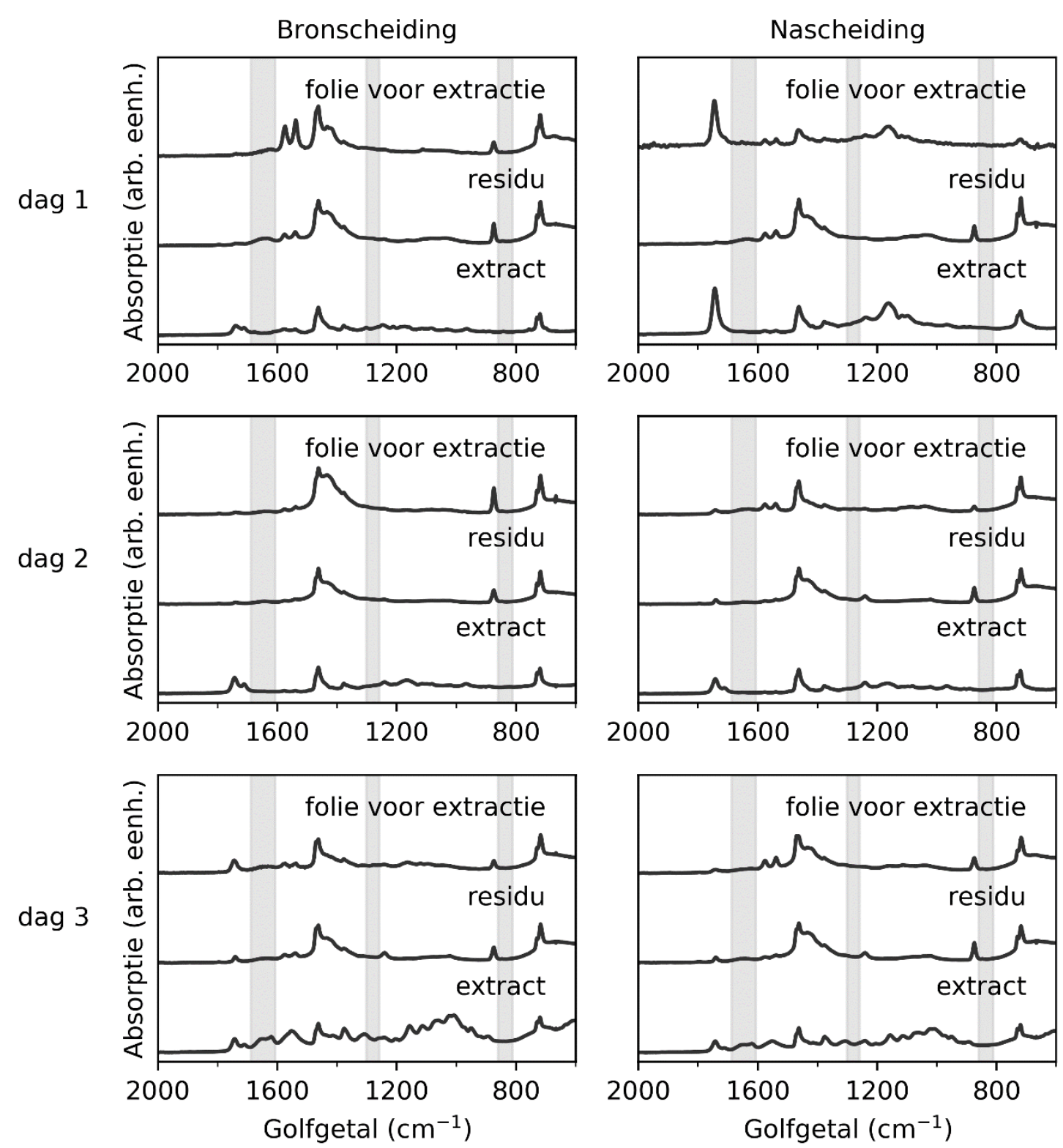

Figuur 3 Overzicht van representatieve infrarood spectra (ingezoomd van $2000 \mathrm{~cm}^{-1}$ tot $600 \mathrm{~cm}^{-1}$ ) van alle Albert Heijn tassen voor extractie, van het extract en het residu. De grijs gearceerde gebieden geven weer waar eventuele signalen kunnen worden toegeschreven aan de bedrukking op de Albert Heijn tassen

Een meer nauwkeurige analyse methode om de kleine concentraties geurstoffen te kunnen aantonen is GC-MS. Figuur 4 geeft voorbeelden van een typisch chromatogram van de vluchtige stoffen (stoffen met een moleculaire massa tot $200 \mathrm{~g} / \mathrm{mol}$ ) aangetroffen in monsters genomen uit bron- en nascheiding. In Bijlage 1 zijn alle overige gaschromatogrammen weergegeven. Het valt op dat de onderlinge variatie in chromatogrammen van de monsters genomen op verschillende bemonsterdagen, ongeacht de herkomst van het folie, bijzonder groot is. Dit maakt een statistisch onderbouwde analyse vrijwel onmogelijk. 


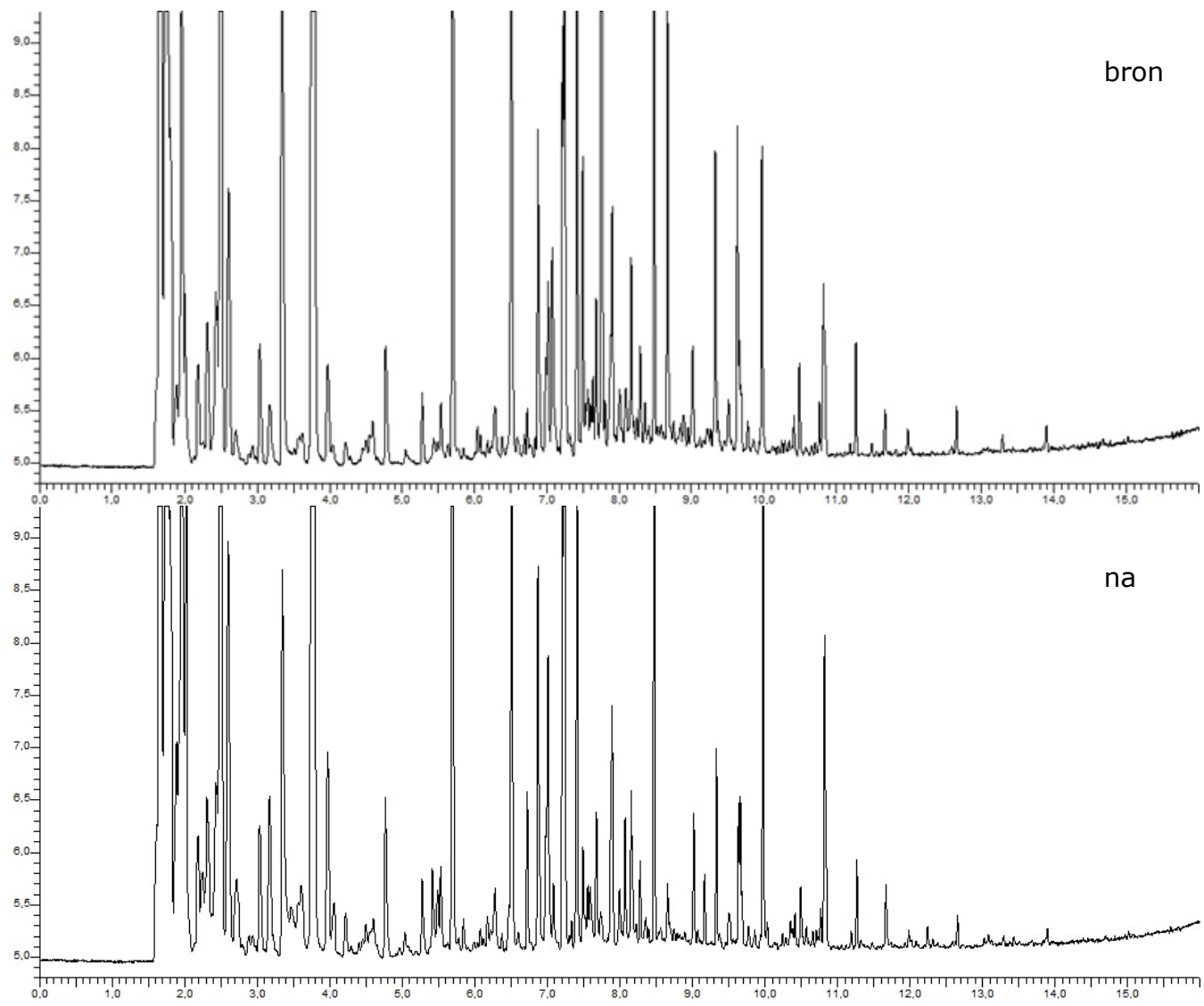

Figuur 4 Voorbeelden van een typisch gaschromatogram voor de vluchtige stoffen aangetroffen in een folie (Albert Heijn tas) afkomstig uit bronscheiding (boven) en nascheiding (onder)

Het valt op dat voor zowel bron- als nascheiding een bijzonder grote hoeveelheid pieken gedetecteerd wordt, wat aangeeft dat er veel verschillende vluchtige stoffen in de folie zijn aangetroffen (elke piek correspondeert met een organische verbinding). Echter door de grote hoeveelheid aan pieken en overlap tussen de pieken kunnen deze niet individueel geïdentificeerd en gekwantificeerd worden binnen een redelijke tijd, en is het dus niet bekend welke vluchtige organische verbindingen allemaal zijn aangetroffen in het folie.

De grote variatie binnen de resultaten van zowel bron- als nascheiding maakt het lastig om conclusies te kunnen trekken over de beste manier van inzamelen om de moleculaire verontreiniging door vluchtige stoffen te minimaliseren. De folie N3 bevat in vergelijking met alle andere monsters meer vluchtige stoffen. Dit zou de indruk kunnen wekken dat er meer moleculaire verontreiniging optreedt bij nascheiding. Om hier echter met statistische relevantie een conclusie te kunnen trekken zullen er van beide inzamelmethoden op significant meer dagen monsters genomen en geanalyseerd moeten worden.

Naast een analyse van de vluchtige stoffen zijn ook de aanwezige gemiddeld tot niet vluchtige moleculaire verontreinigingen geanalyseerd voor alle monsters. Dit zijn stoffen met een moleculaire massa van $150-750 \mathrm{~g} / \mathrm{mol}$. Voor de analyse van deze stoffen is gebruik gemaakt van twee referentiestoffen; buthylhydroxyanisol (BHA) en Tinuvin 243. De pieken van deze stoffen zijn dan ook in alle gaschromatogrammen terug te vinden. In Bijlage 1 zijn alle chromatogrammen weergegeven. Over het algemeen is het aantal gedetecteerde gemiddeld tot niet vluchtige organische verbindingen een stuk lager dan de vluchtige organische verbindingen.

Ook voor de gemiddeld tot niet vluchtige stoffen zijn de aangetroffen organische verbindingen van zowel bron- als nascheiding in grote lijnen vergelijkbaar, echter zijn er ook een aantal kleine verschillen tussen aangetroffen organische verbindingen in de monsters. Daarnaast zijn er ook verschillen in concentratie van deze verbindingen gemeten. Voor een gedetailleerd overzicht van de aangetroffen organische verbindingen en concentraties wordt verwezen naar Bijlage 1 . Figuur 5 geeft 
een overzicht van de concentratie van een aantal gemiddeld tot niet-vluchtige organische verbindingen aangetroffen in de Albert Heijn tassen.
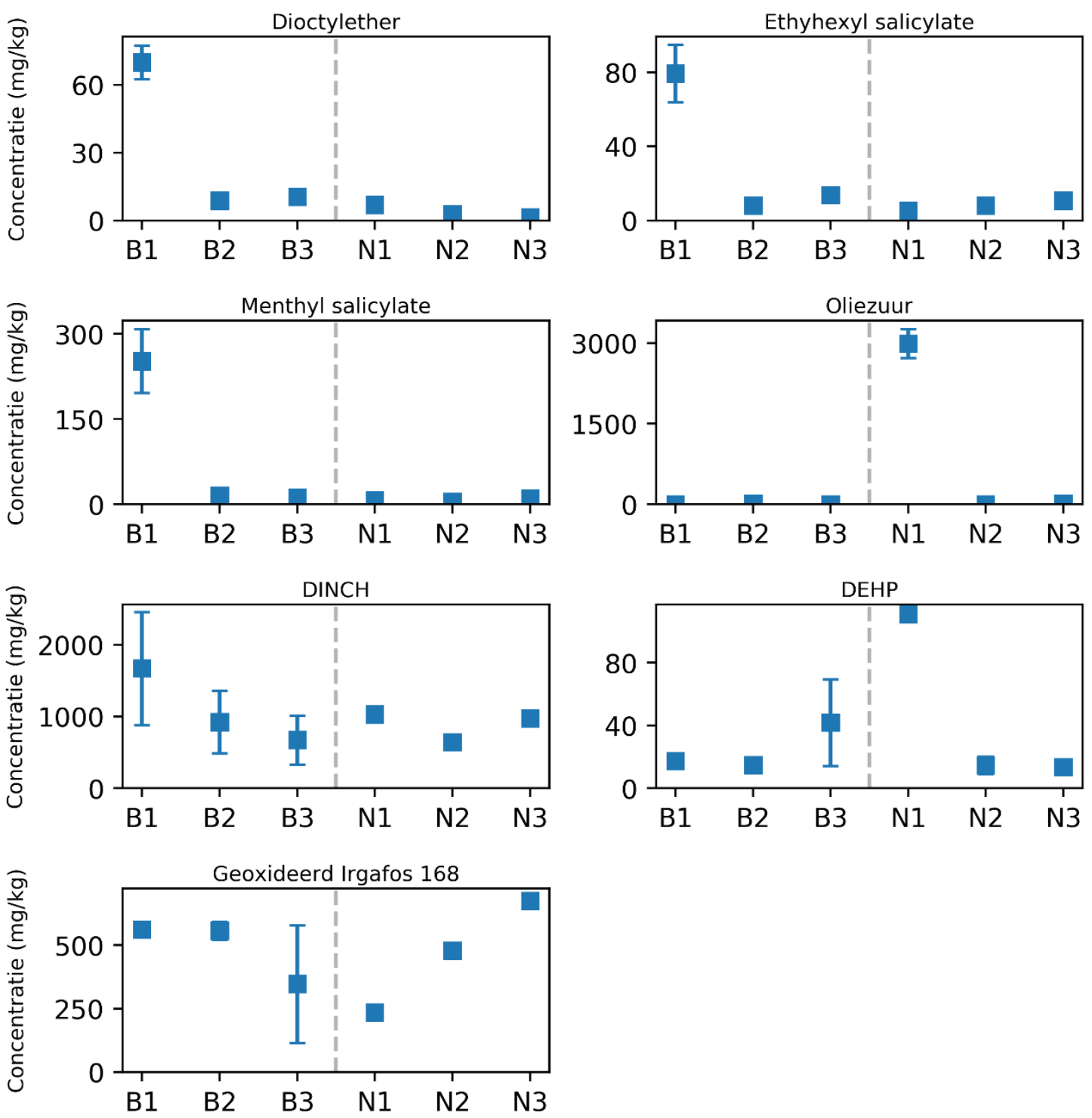

\section{Figuur 5 Concentraties van aangetroffen stoffen (gemiddeld tot niet vluchtig) in de Albert Heijn tassen geanalyseerd door middel van GC-MS}

Monster B1 lijkt de meeste contaminatie te bevatten. Er is een significant hogere concentratie dioctylether, ethylhexyl salicylate en menthyl salicylate gemeten dan voor de overige monsters. Tevens is de concentratie di-isononyl-1,2-cyclohexaandicarboxylaat (DINCH, een niet-ftalaat weekmaker voor PVC) hoger, al is dit verschil minder significant. Dioctylether is een bestanddeel van onder andere verzachtende crèmes en lotions. Menthyl salicylate wordt gebruikt in crèmes en lotions die spier- en/of gewrichtspijn verlichten, in mondspoeling en in cosmetica. Ook ethylhexyl salicylate is terug te vinden in crèmes en lotions vanwege zijn UVB absorptie capaciteit.

Het chromatogram van monster B3 bevat een periodieke reeks pieken die behoren tot een serie alkanen: octadecaan $\left(\mathrm{C}_{18} \mathrm{H}_{38}\right)$, eicosaan $\left(\mathrm{C}_{20} \mathrm{H}_{42}\right)$, docosaan $\left(\mathrm{C}_{22} \mathrm{H}_{46}\right)$, tetracosaan $\left(\mathrm{C}_{24} \mathrm{H}_{50}\right)$, hexacosaan $\left(\mathrm{C}_{26} \mathrm{H}_{54}\right)$, octacosaan $\left(\mathrm{C}_{28} \mathrm{H}_{58}\right)$. Opvallend is dat deze reeks alkanen niet is aangetroffen in de overige monsters. Deze alkanen kunnen behoren tot PE-oligomeren (korte stukjes PE) in HDPE, of deze alkanen kunnen behoren tot de groep zogeheten MOSH verbindingen (mineral oil saturated hydrocarbons, verzadigde koolwaterstoffen) die kunnen voorkomen in bijvoorbeeld drukinkt (voornamelijk uit kranten), smeermiddel, lijm of vaseline. 
Monster N1 bevat een bovengemiddeld hoge concentratie oliezuur, een natuurlijk vetzuur dat voorkomt in onder andere plantaardige oliën (bijvoorbeeld olijfolie en zonnebloemolie) en dierlijke vetten. De aanwezigheid van oliezuur zou ook het signaal bij $1750 \mathrm{~cm}^{-1}$ in het infrarood spectrum kunnen verklaren. Ook is de concentratie bis(2-ethylhexyl)ftalaat (DEHP, gebruikt als weekmaker voor onder andere PVC, hydraulische vloeistof en oplosmiddel) significant hoger in monster N1 dan in alle andere monsters.

Opvallend is ook de wisselende concentraties van het oxidatieproduct van Irgafos 168, een veelgebruikt anti-oxidant toegevoegd aan verscheidene polymeren waaronder ook PE.

\subsubsection{Moleculaire verontreiniging in een deelmonster (Taak 1b)}

In taak $1 \mathrm{~b}$ is uit alle zes monsters (drie bronscheiding en drie nascheiding) een willekeurig gekozen deelmonster van $3 \mathrm{~kg}$ genomen. Dit is geanalyseerd voor de moleculaire verontreiniging in het deelmonster.

De massarendementen van het mechanisch recyclingproces voor de zes deelmonsters (B1, B2, B3, $\mathrm{N} 1, \mathrm{~N} 2, \mathrm{~N} 3$ ) door te wassen in koud water zonder detergentia zijn samengevat in Tabel 4. Hieruit blijkt dat het nagescheiden en gesorteerde folie-materiaal (N1-N3) zoals verwacht vochtiger was en lagere productopbrengsten geeft omdat er meer papier en aangehecht vuil moet worden afgescheiden als slib en opgeloste stof. Het drijfgoed is het hoofdproduct en dit werd verder bestudeerd.

Tabel 4 Massarendementen van de mechanische recycling van sorteerproduct tot gewassen maalgoed gerekend naar droge stof $[\%(m / m)]$ en het vochtgehalte van de grondstof (ongewassen maalgoed).

\begin{tabular}{llllll} 
Deelmonster & $\begin{array}{l}\text { Drijfgoed } \\
\text { (Product) }\end{array}$ & $\begin{array}{l}\text { Zinkgoed } \\
\text { (Bijproduct) }\end{array}$ & $\begin{array}{l}\text { Slib } \\
\text { (Afval) }\end{array}$ & & Opgeloste stof Vochtgehalte \\
B1 & $80.6 \pm 0.8$ & $7.3 \pm 0.1$ & $2.7 \pm 0.1$ & $9.4 \pm 0.5$ & $5.0 \pm 0.9$ \\
\hline B2 & $81.6 \pm 0.3$ & $8.6 \pm 0.1$ & $2.0 \pm 0.1$ & $7.8 \pm 0.5$ & $2.1 \pm 0.3$ \\
\hline B3 & $77.7 \pm 0.9$ & $8.9 \pm 0.1$ & $2.2 \pm 0.1$ & $11.3 \pm 0.7$ & $9.7 \pm 1.0$ \\
\hline N1 & $62.3 \pm 2.8$ & $14.0 \pm 0.6$ & $4.4 \pm 0.2$ & $19.3 \pm 0.6$ & $39 \pm 3$ \\
\hline N2 & $63.6 \pm 0.7$ & $6.9 \pm 0.1$ & $6.5 \pm 0.1$ & $23.0 \pm 1.0$ & $26.3 \pm 0.8$ \\
\hline
\end{tabular}

Omdat uit taak $1 \mathrm{a}$ is gebleken dat hexaanextractie niet geschikt is om de moleculaire verontreiniging te kunnen bepalen is er in taak 1b gekozen om alleen GC-MS analyse te gebruiken in combinatie met een geurpanelanalyse voor het bestuderen van de moleculaire verontreiniging in de zes hoofdrecyclingproducten.

In Bijlage 2 zijn alle chromatogrammen van de vluchtige stoffen aangetroffen in de deelmonsters te vinden. Wederom laten de chromatogrammen een zeer groot aantal pieken zien. Door het grote aantal kunnen deze niet geïdentificeerd worden. Het valt echter op dat over het algemeen er iets meer pieken, en dus vluchtige stoffen, zijn aangetroffen in de monsters afkomstig uit nascheiding in vergelijking met monsters afkomstig uit bronscheiding. Monsters afkomstig uit bron- en nascheiding lopen redelijkerwijs dezelfde processtappen door (denk aan temperatuur, windzifters, etc.), het belangrijkste verschil zit in het contact met andere materialen tijdens het proces. Bij bronscheiding zijn dit voornamelijk productresten, bij nascheiding is dit voornamelijk ontbindend organisch materiaal. Klaarblijkelijk leidt dit bij nascheiding tot meer pieken. Het verschil in aantal pieken zegt echter nog niks over de aanwezigheid van geur.

Daarnaast zijn in Bijlage 2 ook alle chromatogrammen van de gemiddeld tot niet vluchtige stoffen weergegeven. De patronen van de pieken lijken weinig te verschillen tussen bron- en nascheiding. Dit wordt ook bevestigd in Figuur 6 waarin de concentraties van verschillende aangetroffen stoffen wordt weergegeven voor de drie deelmonsters van zowel bronscheiding als nascheiding. Submonster N1-kz laat een hogere concentratie van een aantal ongeïdentificeerde koolwaterstoffen zien. Dit is niet in overeenstemming met submonster N2-kz en N3-kz waardoor dit als incidentele verontreiniging gezien kan worden. De identificatie van deze koolwaterstoffen was niet mogelijk wegens de afwezigheid van 
de moleculaire massa piek in de massa spectra. Vanuit de fragmentatie patronen kan echter wel met zekerheid worden gesteld dat dit verzadigde koolwaterstoffen betreft.

Opvallend is van de stoffen die zowel in taak $1 \mathrm{a}$ als in taak $1 \mathrm{~b}$ zijn aangetroffen (oliezuur, DEHP en geoxideerd Irgafos 168) dat de gemeten concentraties sterk verschillen tussen de geanalyseerde folies uit taak $1 \mathrm{a}$ en taak $1 \mathrm{~b}$, ook al komen ze oorspronkelijk uit hetzelfde monster van $50 \mathrm{~kg}$ (zie ook Figuur 52 in Bijlage 2). Zo is de concentratie oliezuur in de Albert Heijn tassen nagenoeg nul met een uitzondering van de Albert Heijn tassen uit monster N1. Wanneer er echter een submonster van drie $\mathrm{kg}$ wordt genomen (taak $1 \mathrm{~b}$ ), is de concentratie oliezuur in submonster N1 nagenoeg nul, maar die van de andere monsters $500 \mathrm{mg} / \mathrm{kg}$ of hoger. De concentratie DEHP (een weekmaker) laat een zelfde trend zien voor zowel de Albert Heijn tassen als de submonsters. Echter is de concentratie DEHP in de submonsters een stuk hoger dan in de Albert Heijn tassen. De concentraties van geoxideerd Irgafos 168 zijn net als voor DEHP hoger voor de submonsters dan voor de Albert Heijn tassen. 

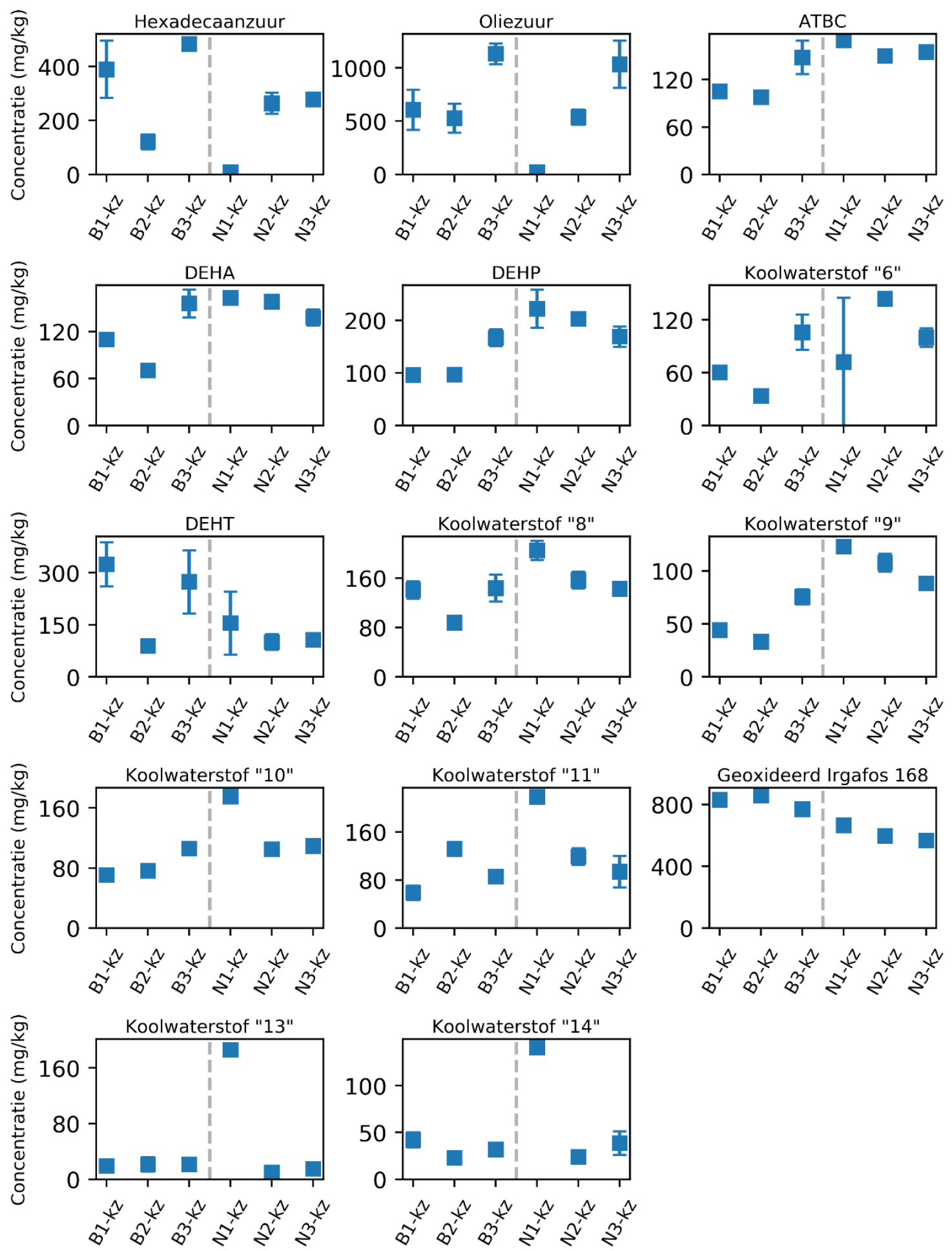

Figuur 6 Concentraties van aangetroffen stoffen (gemiddeld tot niet vluchtig) in de deelmonsters geanalyseerd door middel van GC-MS

Naast de GC-MS analyse, heeft er ook een geurpanelanalyse plaatsgevonden. Figuur 7 laat de uitkomsten van deze analyse zien door middel van een radardiagram. Naarmate een geureigenschap intenser wordt ervaren, ligt dit punt verder van het middelpunt van het diagram af. Het valt bijvoorbeeld meteen op dat de testpanelleden bij deelmonsters B2-kz en B3-kz een intense vettige en ranzige geur ervaren terwijl dit bij de submonsters uit nascheiding niet zo wordt ervaren. 

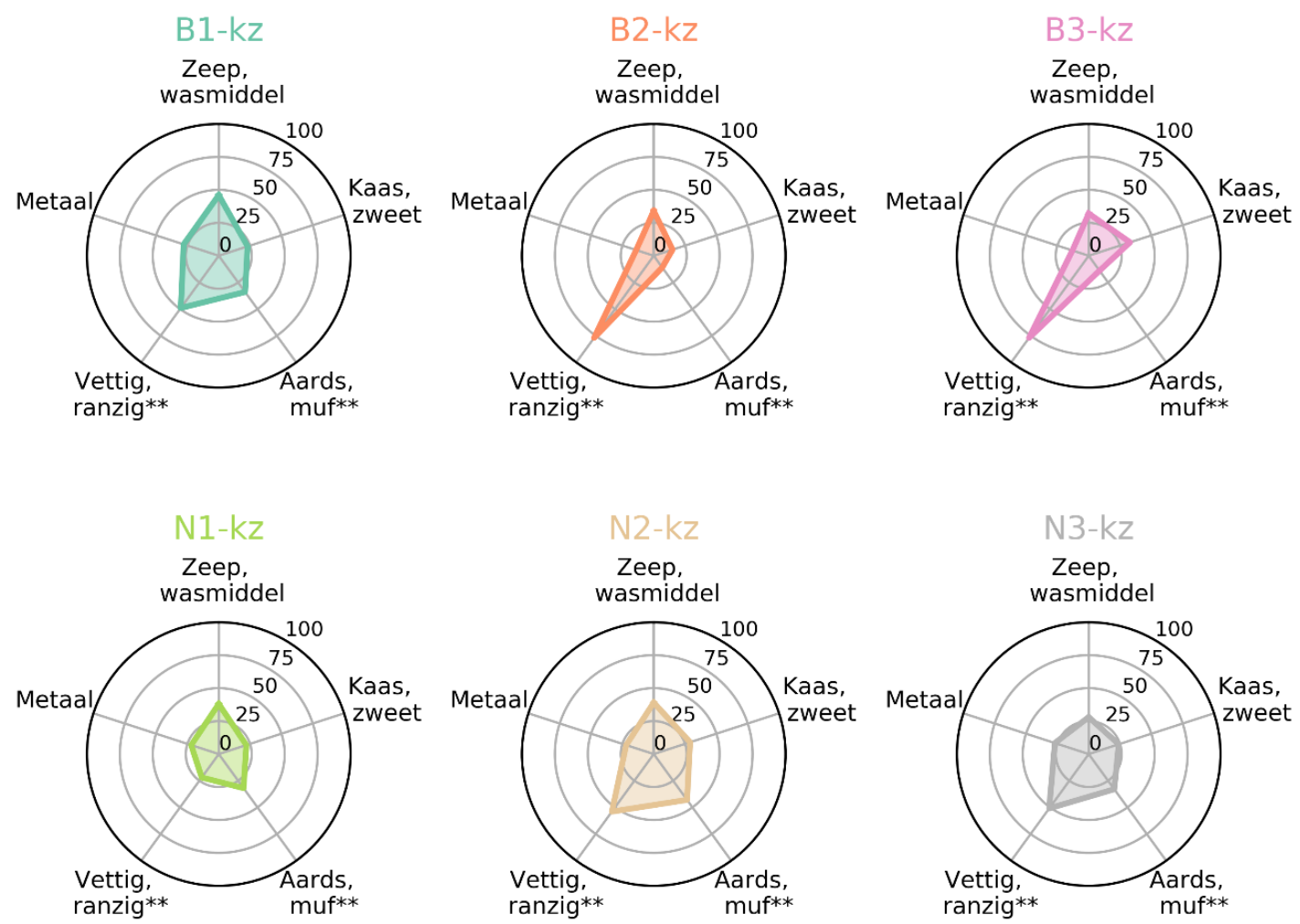

\section{Figuur 7 Uitkomsten van de geurpanelanalyse, ${ }^{* *}$ betekent een significant verschil ( $a \leq 0.05$ ) bepaald door middel van een ANOVA test}

Tabel 5 geeft weer welke geureigenschappen significant verschillen (verschillende letters) tussen de submonsters en welke niet (gelijke letters) bepaald met de Duncan test. Er kan geconcludeerd worden dat er geen significante verschillen tussen alle submonsters zijn aangetroffen in de geureigenschappen zeepachtig, wasmiddel-achtig, kaasachtig, zweetachtig en metaalachtig.

Significante verschillen zijn wel aangetroffen voor de geureigenschap aards, muf tussen submonsters N2-kz en submonsters B2-kz en B3-kz. Met enige voorzichtigheid kan er geconcludeerd worden dat de submonsters uit nascheiding in enkele gevallen een iets intensere aardse, muffe geur hebben. Echter is dit wel gebaseerd op individuele submonsters (er is bijvoorbeeld geen significant verschil tussen submonsters B1-kz, N1-kz en N3-kz). Naast de geureigenschap aards, muf zijn er ook significante verschillen aangetroffen voor de geureigenschap ranzig nootachtig. Zo is het verschil voor zowel B1-kz, B2-kz en N1-kz als voor B1-kz, B3-kz en N1-kz significant. Ook hier kan op basis van individuele submonsters voorzichtig geconcludeerd worden dat de submonsters uit bronscheiding een intensere ranzig nootachtige geur hebben.

Tabel 5 Resultaten van de Duncan test. Verschillende letters voor een bepaalde geureigenschap betekent een significant verschil, $a \leq 0.05$.

\begin{tabular}{lllllll} 
Geureigenschap & \multicolumn{2}{c}{ Bronscheiding } & \multicolumn{2}{c}{ Nascheiding } \\
Zeepachtig, wasmiddelachtig & B & A & A & A & A & A \\
\hline Kaasachtig, zweetachtig & A & A & A & A & A & A \\
\hline Aards, muf & AB & B & B & AB & A & AB \\
\hline Ranzig nootachtig & B & A & A & C & AB & AB \\
\hline Metaalachtig & A & A & A & A & A & A
\end{tabular}




\subsection{Deelconclusie}

De resultaten uit deze taak laten geen significant verschil zien tussen de verontreiniging in monsters uit bron- en nascheiding. Voor zowel de monsters afkomstig uit bron- en nascheiding is de onderlinge variatie groot wat het lastig maakt om conclusies te trekken.

Als eerste zijn Albert Heijn draagtassen uit de monsters gesorteerd, gewassen met een basiswas (koud water zonder detergentia) en geanalyseerd. De chromatogrammen van de vluchtige stoffen, de stoffen die de meeste impact hebben op geur, uit de draagtassen laten veelal dezelfde stoffen zien, al dan niet met verschillende concentraties. Vanwege de hoge vluchtigheid van deze stoffen kunnen de verschillen tussen de monsters erg groot zijn. Om significante conclusies te kunnen trekken zouden veel meer monsters geanalyseerd moeten worden en ook grotere monsters (niet alleen enkele tassen). Hiervoor is een deelmonster van circa $3 \mathrm{~kg}$ uit het resterende sorteerproduct genomen, gewassen met een basiswas en geanalyseerd.

Ook de deelmonsters zijn geanalyseerd met GC-MS. Hieruit blijkt wederom dat er een grote onderlinge variatie in de monsters zit, die vaak groter is dan het verschil in bron- en nascheiding. Naast de analyse door middel van GC-MS is ook een geurpanelanalyse uitgevoerd op deze submonsters. Hieruit bleek dat er geen significant verschil in geurbeleving tussen de deelmonsters afkomstig uit bron- en nascheiding is voor de volgende geurprofielen: zeepachtig, wasmiddel-achtig, kaasachtig, zweetachtig en metaalachtig.

Er zijn wel significante verschillen in geurbeleving gemeten voor de geurprofielen aards, muf en ranzig nootachtig. Aangezien er ook tussen de verschillende deelmonsters uit zowel bron- als nascheiding een verschil in intensiteit is gemeten, is het lastig om harde conclusies te kunnen trekken. Het lijkt erop dat deelmonsters uit nascheiding een iets sterkere aardse, muffige geur hebben. Een duidelijker verschil is zichtbaar voor het geurprofiel ranzig nootachtig, waarin twee van de drie bronscheiding submonsters een zeer intense geurbeleving hebben, wat veel minder aanwezig is in de submonsters afkomstig van nascheiding. 


\section{Taak 2: Invloed recyclingwijze op de moleculaire verontreiniging}

Twee stappen in het recyclingproces hebben mogelijk invloed op de moleculaire verontreiniging van gerecyclede kunststoffen; de waswijze en het ontgassen met vacuüm tijdens het extruderen van het recyclaat. Deze taak onderzoekt het effect van de recyclingwijze op de moleculaire verontreiniging in het sorteerproduct film.

\subsection{Onderzoeksmethode}

Voor deze taak is gekozen om met 1 monster van nascheiding en 1 monster van bronscheiding verder te gaan. De keuze is gemaakt voor monsters N2 en B2, omdat deze in de resultaten van taak 1 het meest gemiddeld waren en geen afwijkingen in verontreinigingen lieten zien. Deze twee materialen werden op zes verschillende manieren mechanisch gerecycled, geëxtrudeerd en al of niet gevacumeerd tijdens de extrusie, zie voor de opzet de onderstaande tabel.

Tabel 6 Processtappen, bijbehorende monstercodes en geselecteerde analyses voor

taak 2

\begin{tabular}{lllll} 
Monstercode & Oorsprong & Waswijze & Vacumeren & Analyses \\
B2-KZ-E & Bron & Koud water & Nee & GC-MS, geurpanel \\
\hline N2-KZ-E & Na & Koud water & Nee & GC-MS, geurpanel \\
\hline B2-KM-E & Bron & Koud water, $0.01 \mathrm{M} \mathrm{NaOH}$ & Nee & GC-MS, geurpanel \\
\hline N2-KM-E & Na & Koud water, $0.01 \mathrm{M} \mathrm{NaOH}$ & Nee & GC-MS, geurpanel \\
\hline B2-WZ-E & Bron & Warm water & Nee & GC-MS, geurpanel \\
\hline N2-WZ-E & Na & Warm water & Nee & GC-MS, geurpanel \\
\hline B2-WM-E & Bron & Warm water, $0.01 \mathrm{M} \mathrm{NaOH}$ & Nee & GC-MS, geurpanel \\
N2-WM-E & Na & Warm water, $0.01 \mathrm{M} \mathrm{NaOH}$ & Nee & GC-MS, geurpanel \\
\hline B2-KZ-EV & Bron & Koud water & Ja & GC-MS, geurpanel \\
\hline B2-WM-EV & Bron & Warm water, $0.01 \mathrm{M} \mathrm{NaOH}$ & Ja & GC-MS, geurpanel \\
\hline N2-KZ-EV & $\mathrm{Na}$ & Koud water & Ja & GC-MS, geurpanel \\
\hline N2-WM-EV & $\mathrm{Na}$ & Warm water, $0.01 \mathrm{M} \mathrm{NaOH}$ & Ja & GC-MS, geurpanel
\end{tabular}

Voor extrusie is gebruik gemaakt van een Berstorff ZE $25(C L) * 40$ D extruder met een doorvoer van $3 \mathrm{~kg} / \mathrm{h}$. De extruder bestaat uit 10+2 zones, de laatste twee zones zijn koppelstukken aan het eind van de extruder voor en na het smeltfilter en voor het kopstuk. Een schema van de extruder van smeltfilter tot voed-zones staat weergegeven in Figuur 8. Het smeltfilter bestaat uit twee filterhouders die handmatig verwisseld kunnen worden. Het verwisselen van de smeltfilters wordt gedaan bij 60 bar, dan zijn de filters vol. Er worden twee filters over elkaar heen gebruikt; één met een maaswijdte van $250 \mu \mathrm{m}$ en één van $400 \mu \mathrm{m}$. In dit geval zaten de filters zo snel vol dat ervoor is gekozen om de filters niet te gebruiken. Gevolg hiervan is dat deeltjes die normaal in dit filter achterblijven (deeltjes die niet smelten bij temperaturen rond $190^{\circ} \mathrm{C}$, zoals PET en aluminium) in het geproduceerde materiaal terechtkomen. De ingestelde temperatuur per zone staan weergegeven in Tabel 7. Het ontgassen (vacumeren) aan het eind van de extruder (Z10) is gedaan om schuimen te voorkomen en vluchtige verontreinigingen (dampen) uit de smelt te onttrekken. De vacuümdruk varieerde rond de 10 mbar. Een kopstuk met 2 gaten van $2 \mathrm{~mm}$ is gebruikt. De warme strengen werden gekoeld in een koudwaterbad en gesneden met een granulator op lage snelheden. 


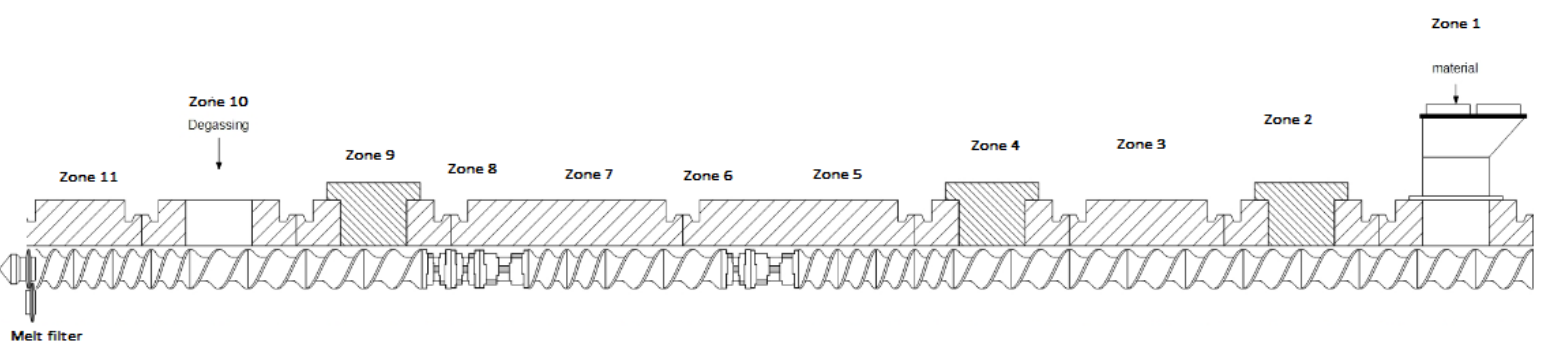

Figur 8 Schematische weergave van de extruder van smeltfilter (zone 11) tot voedzone (zone 1)

Tabel $7 \quad$ Ingestelde temperatuur in graden Celsius per zone van de extruder.

\begin{tabular}{llllllllllllll} 
& Z1 & Z2 & Z3 & Z4 & Z5 & Z6 & Z7 & Z8 & Z9 & Z10 & Z11 & Z12 \\
Ingestelde temperatuur $\left({ }^{\circ} \mathrm{C}\right)$ & - & \multirow{2}{*}{50} & \multirow{2}{*}{185} & \multirow{2}{*}{185} & \multirow{2}{*}{185} & \multirow{2}{*}{190} & \multirow{2}{*}{190} & \multirow{2}{*}{195} & \multirow{2}{*}{195} & \multirow{2}{*}{195} & \multirow{2}{*}{195} & 195
\end{tabular}

\subsection{Resultaten en discussie}

De massarendementen van het mechanisch recyclingproces voor de twaalf deelmonsters, die op verschillende manieren zijn gewassen, zijn samengevat in Tabel 8 . Hieruit blijkt dat het brongescheiden ingezamelde en gesorteerde folieproduct veel droger is, minder aangehecht vuil bevat waardoor de massarendementen op droge stofbasis duidelijk hoger uitvallen dan van het nagescheiden folieproduct. Uit voorgaand onderzoek bleek dat warm wassen van folie met natronloog $(\mathrm{NaOH})$ leidde tot hogere rendementen zinkgoed en slib dan wassen met koud water, waarschijnlijk doordat etiketten en de materialen beter losgemaakt konden worden. Dat blijkt nu niet uit deze resultaten. Bovendien variëren de resultaten ook fors tussen herhaalmonsters, wat vermoedelijk zijn oorsprong vindt in de heterogeniteit van de gesorteerde foliemonsters.

Tabel 8 Massarendementen van de mechanische recycling van sorteerproduct tot gewassen maalgoed gerekend naar droge stof $[\%(m / m)]$ en het vochtgehalte van de grondstof (ongewassen maalgoed).

\begin{tabular}{llllll} 
Monstercode & $\begin{array}{l}\text { Drijfgoed } \\
\text { (Product) }\end{array}$ & $\begin{array}{l}\text { Zinkgoed } \\
\text { (Bijproduct) }\end{array}$ & Slib & Opgeloste stof & Vochtgehalte \\
B2-kz-e & $82.6 \pm 0.9$ & $6.2 \pm 0.1$ & $3.3 \pm 0.1$ & $7.9 \pm 0.4$ & $3.9 \pm 1.0$ \\
\hline N2-kz-e & $65.6 \pm 0.6$ & $9.9 \pm 0.1$ & $6.3 \pm 0.1$ & $18.2 \pm 0.7$ & $31.3 \pm 0.6$ \\
\hline B2-km-e & $80.7 \pm 0.8$ & $7.8 \pm 0.1$ & $4.4 \pm 0.1$ & $7.1 \pm 0.3$ & $3.9 \pm 1.0$ \\
\hline N2-km-e & $60 \pm 4$ & $8.1 \pm 0.6$ & $14 \pm 1$ & $18 \pm 2$ & $37 \pm 5$ \\
\hline B2-wz-e & $78.4 \pm 0.4$ & $8.2 \pm 0.1$ & $3.9 \pm 0.1$ & $9.5 \pm 0.4$ & $1.9 \pm 0.5$ \\
\hline N2-wz-e & $62.2 \pm 0.8$ & $8.4 \pm 0.1$ & $8.5 \pm 0.1$ & $20.9 \pm 0.7$ & $37 \pm 1$ \\
\hline B2-wm-e & $82.2 \pm 0.2$ & $3.8 \pm 0.1$ & $2.9 \pm 0.1$ & $11.1 \pm 0.6$ & $2.2 \pm 0.2$ \\
\hline N2-wm-e & $62.8 \pm 0.9$ & $6.1 \pm 0.1$ & $13.8 \pm 0.2$ & $17.2 \pm 0.5$ & $36 \pm 1$ \\
\hline B2-kz-ev & $82.0 \pm 0.6$ & $7.9 \pm 0.1$ & $2.6 \pm 0.1$ & $7.5 \pm 0.4$ & $3.2 \pm 0.7$ \\
B2-wm-ev & $80.9 \pm 0.7$ & $5.4 \pm 0.1$ & $3.5 \pm 0.1$ & $10.2 \pm 0.5$ & $2.2 \pm 0.8$ \\
\hline N2-kz-ev & $64.6 \pm 0.8$ & $10.6 \pm 0.1$ & $8.8 \pm 0.1$ & $16.0 \pm 0.6$ & $31 \pm 1$ \\
N2-wm-ev & $43 \pm 3$ & $11.3 \pm 0.7$ & $11.5 \pm 0.7$ & $34 \pm 3$ & $21 \pm 5$ \\
\hline
\end{tabular}

$\mathrm{Na}$ het mechanisch recyclen zijn de twaalf deelmonsters geëxtrudeerd. Tijdens het extruderen zijn de volgende observaties gedaan:

- $\quad$ Monsters N2-kz-e en N2-kz-ev hadden veel meer geur dan de overige monsters.

- Bij monster B2-kz-ev is het vacumeren/ontgassen niet helemaal gelukt, door technische problemen.

- $\quad$ Bij de monsters met vacumeren tijdens extrusie (-ev) schuimt het materiaal wat minder en liep het extrusieproces stabieler. Dit geldt ook voor de warm en met loog gewassen monsters. Dit kan erop duiden dat er minder vocht/vervuiling in het monster zit. 
In Figuur 9 zijn foto's van zowel het maalgoed voor extrusie als het granulaat na extrusie weergegeven voor zowel bron- als nascheiding. Ten eerste valt het op dat de kleur van het granulaat afkomstig uit bronscheiding lichter is in vergelijking met het granulaat uit nascheiding. Dit is in overeenstemming met de kleur van het maalgoed voor extrusie. Ten tweede valt het op dat er variatie in de vorm van het granulaat zit, en dat deze variatie onafhankelijk is van bron- of nascheiding. Het granulaat heeft een homogenere en rondere vorm voor de monsters waarin het extrusieproces stabieler liep doordat er minder schuimvorming was. Schuimvorming resulteert in een holle streng die vervolgens in de granulator wordt platgedrukt tot rechthoekig granulaat.

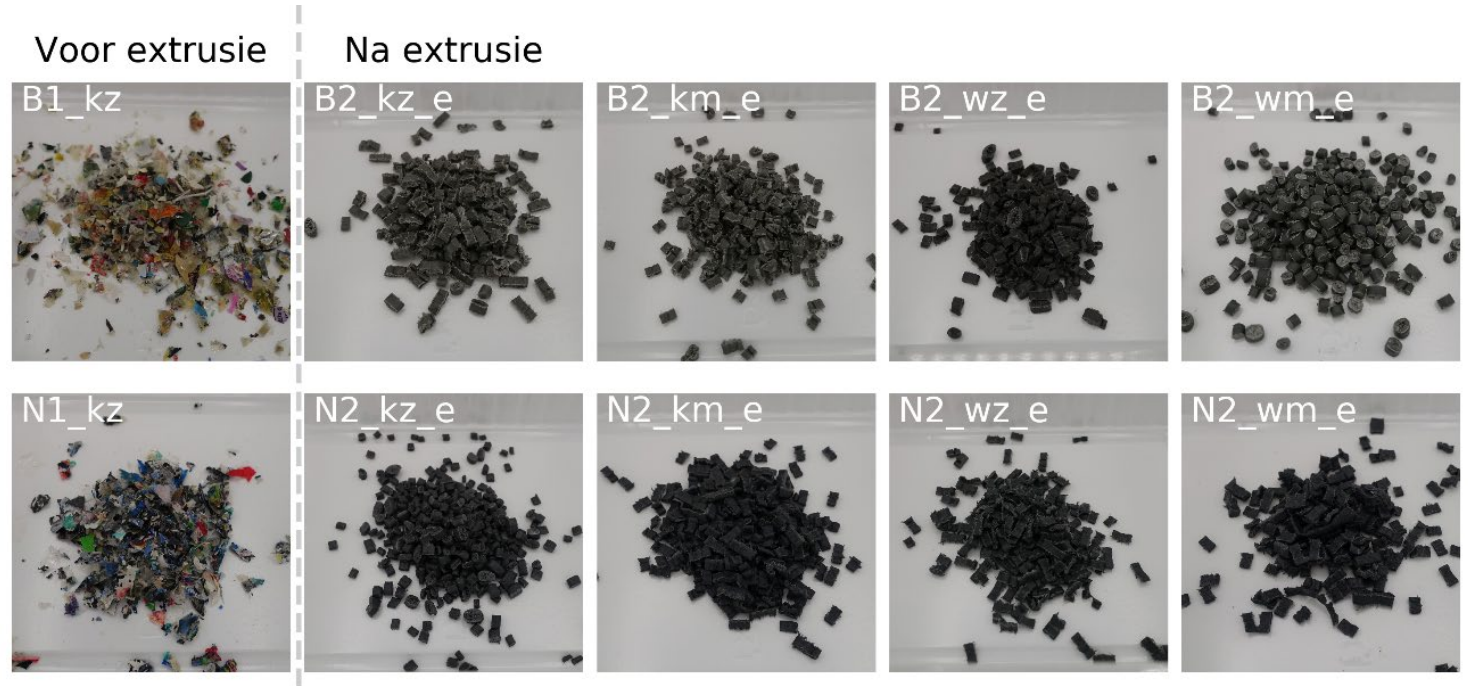

\section{Figuur 9 (links) Foto's van het maalgoed voor extrusie. (rechts) Foto's van het granulaat} na extrusie

De moleculaire verontreiniging van de monsters na verschillende processtappen is onderzocht door middel van GC-MS analyse en een geurpanel. De gaschromatogrammen van de vluchtige en van de gemiddeld tot niet vluchtige stoffen zijn weergegeven in Bijlage 3. Het extruderen van het materiaal laat over het algemeen een reductie zien in het aantal en in de intensiteit van de pieken in de gaschromatogrammen van de vluchtige stoffen ten opzichte van het materiaal uit taak 1b (B2-kz en N2-kz).

De gemeten concentraties aan geïdentificeerde gemiddeld tot niet vluchtige verbindingen zijn samengevat in Figuur 10 voor de gescheiden ingezamelde foliemonsters (bronscheiding) en in Figuur 11 voor de nagescheiden foliemonsters. Hierbij zijn de desbetreffende referentiemonsters van het folie dat wel koud gewassen is zonder natronloog maar niet geëxtrudeerd, respectievelijk monster B2-kz en $\mathrm{N} 2-\mathrm{kz}$, toegevoegd. Opvallend is dat de gaschromatogrammen van de gemiddeld tot niet vluchtige stoffen voor bronscheiding een extra piek op 33 minuten laten zien, in tegenstelling tot de chromatogrammen voor nascheiding. Helaas kon de bijbehorende verbinding niet worden geïdentificeerd omdat er geen signaal in het massaspectrum is gemeten.

De concentratie van enkele verbindingen neemt sterk af door te extruderen (van kz naar kz-e) zoals hexadecaanzuur, oliezuur en enkele hogere koolwaterstoffen voor zowel monsters uit bron- alsmede uit nascheiding. De andere processtappen (wassen met loog, warm wassen, vacumeren) lijken weinig effect te hebben op de meeste identificeerbare verontreinigingen. Bovendien lijken de concentraties van de meeste identificeerbare verontreinigingen nauwelijks te variëren en incidenteel een uitschieter te laten zien, zoals bij enkele weekmakers en lichtere koolwaterstoffen. Dit wordt vermoedelijk veroorzaakt door een monster dat relatief rijker is aan etiketten, waarbij inkt-hulpstoffen naar het folie zijn gemigreerd.

De concentratie van bepaalde verbindingen verschilt sterk tussen bron- en nascheiding, zie Figuur 81 in Bijlage 3. Zo is de concentratie hexadecaanzuur, oliezuur en koolwaterstof "14" duidelijk lager in monsters afkomstig uit nascheiding ten opzichte van bronscheiding. Daarentegen hebben monsters afkomstig uit bronscheiding over het algemeen een lagere concentratie DEHA, koolwaterstof "6" en koolwaterstof " 9 " ten opzichte van folies uit nascheiding. 

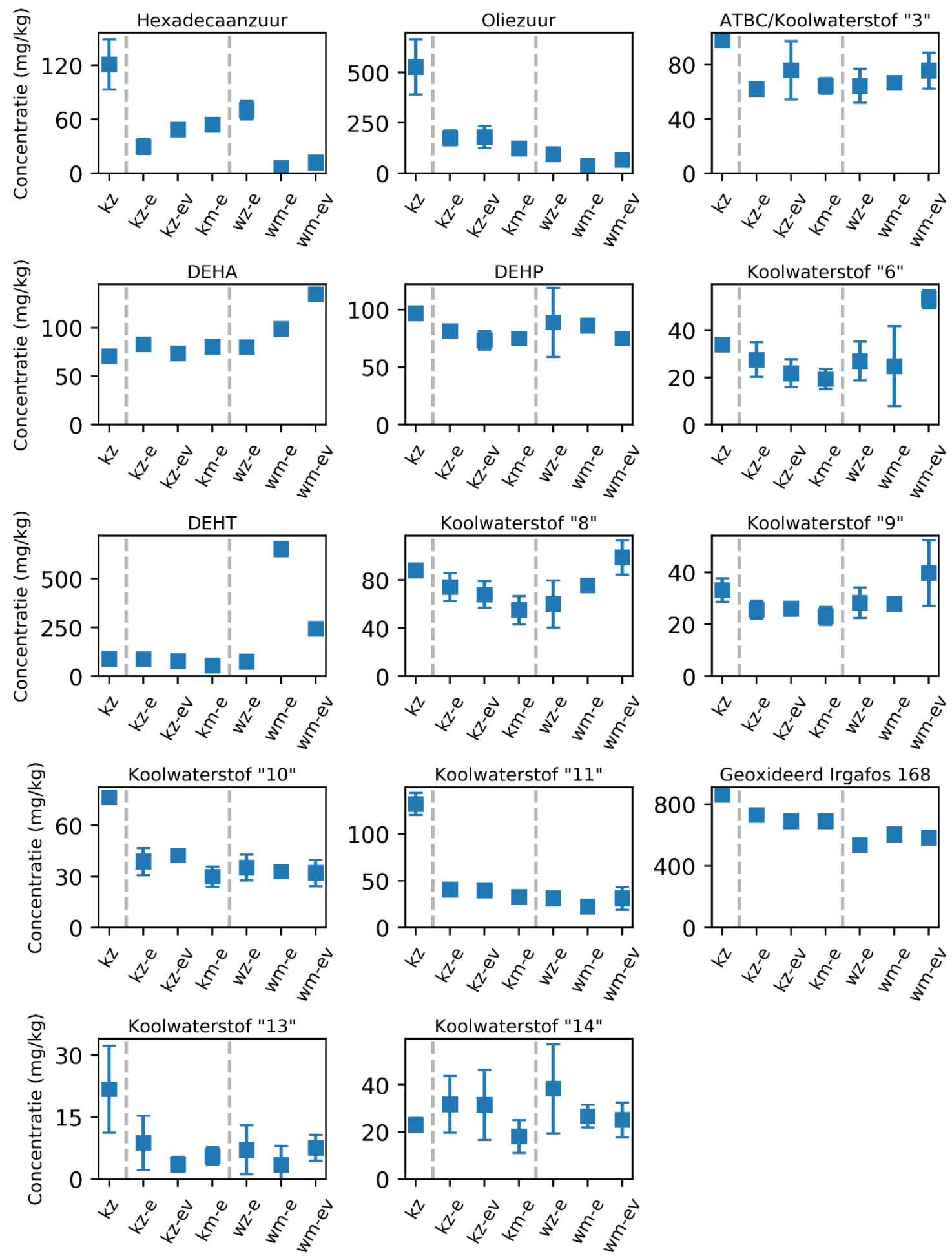

Figuur 10 De gemeten concentratie aan moleculaire verontreiniging (gemiddeld tot niet vluchtige verbindingen) in gescheiden ingezamelde foliemonsters (bronscheiding) die verschillende processtappen hebben ondergaan 

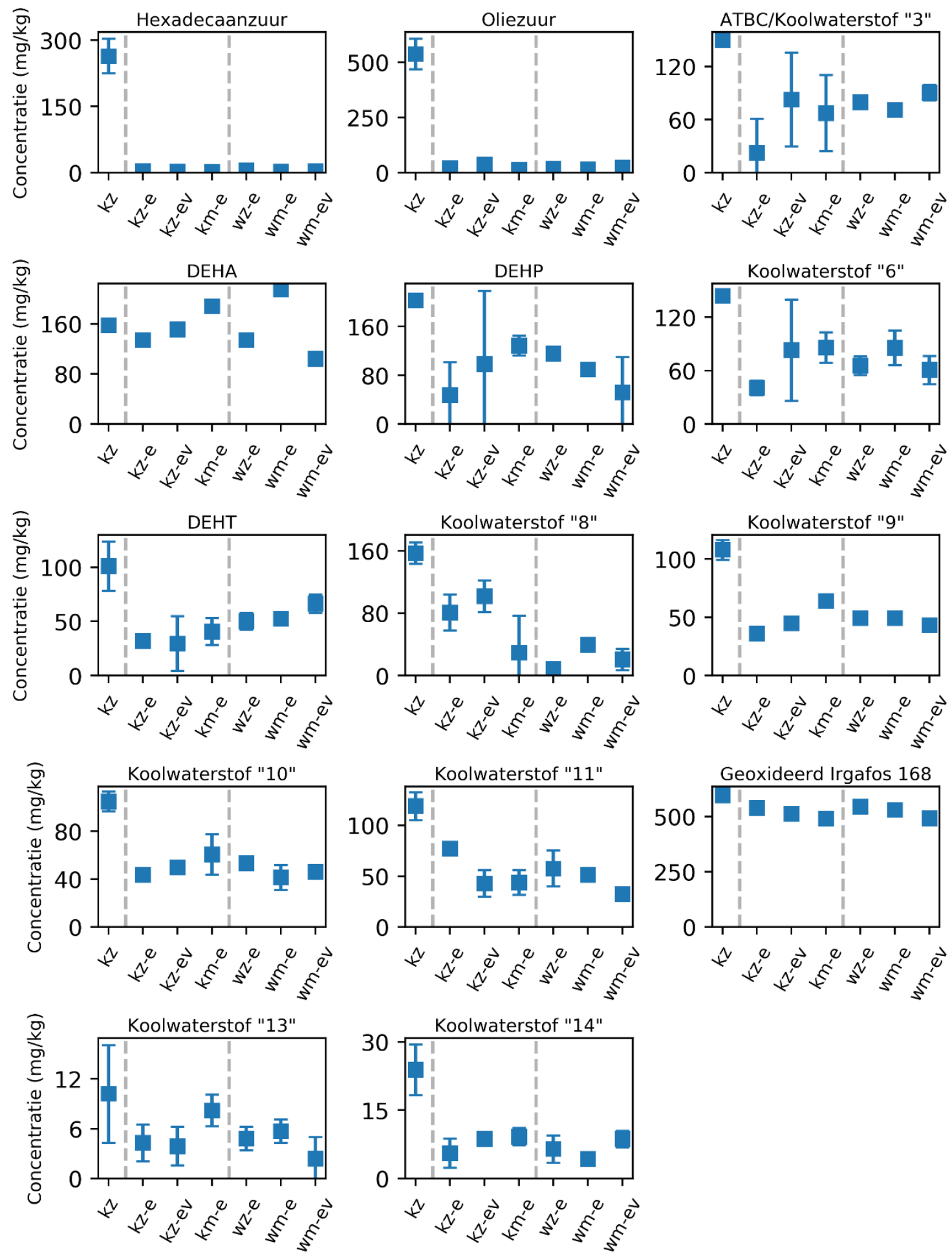

Figuur 11 De gemeten concentratie aan moleculaire verontreiniging (gemiddeld tot niet vluchtige verbindingen) in nagescheiden foliemonsters (nascheiding) die verschillende processtappen hebben ondergaan 
Naast gaschromatografie is een geurpanelanalyse uitgevoerd om de geurintensiteit van bepaalde geureigenschappen te bepalen voor de monsters afkomstig uit bronscheiding (Figuur 12) en nascheiding (Figuur 13). De vorm van de radardiagrammen is voor de monsters uit bronscheiding niet sterk afhankelijk van de doorlopen processtappen, in tegenstelling tot die van de monsters uit nascheiding waar de doorlopen processtappen de vorm van de radardiagrammen sterk beïnvloed. Dit betekent dat er minder variatie in geurbeleving is tussen de verschillende doorlopen processen bij monsters afkomstig uit bronscheiding. Echter zegt dit niks over de verschillen in geurbeleving tussen bron- en nascheiding. Over het algemeen kan er geconcludeerd worden dat de monsters afkomstig uit bronscheiding gekarakteriseerd worden door een vettig ranzige, was, paraffine-achtige en fruitige, amandel geur terwijl de monsters afkomstig uit nascheiding gekarakteriseerd worden door een verbrande, fenolische, inktachtige, gerookte ham en aards, muffe geur.

Daarnaast zijn er enkele opvallende zaken die hieronder puntsgewijs genoemd zullen worden:

- De monsters N2-kz-e en N2-kz-ev hebben een zeer duidelijke verbrande, gerookte, en fenolische geur (deze geuren kunnen door een zelfde type chemische verbindingen veroorzaakt worden). Deze geur was nog niet aanwezig in het gewassen maalgoed en moet dus zijn ontstaan bij verhitting tijdens extrusie. Tijdens de extrusie, vielen deze twee monsters ook op door de opvallende geur t.o.v. andere monsters. Andere geuren zijn in deze monsters nagenoeg niet aanwezig, of compleet overschaduwd door hierboven genoemde geuren. In de overige N2 monsters zijn deze geuren niet sterk aanwezig. Ook zijn deze geuren nagenoeg niet aanwezig in alle monsters afkomstig uit bronscheiding. Wassen met loog en/of warm water lijkt dus een positief effect te hebben op de geurbeleving van de monsters afkomstig uit nascheiding.

- De monsters afkomstig uit nascheiding die zijn gewassen met loog hebben een sterkere zeepgeur dan de monsters die gewassen zijn zonder loog. Dit effect is echter niet aanwezig bij de monsters afkomstig uit bronscheiding. Blijkbaar zijn er in de N2 monsters stoffen aanwezig die in contact met natronloog kunnen verzepen, en dus een zeepachtige geur kunnen verklaren.

- De monsters afkomstig uit bronscheiding scoren over het algemeen hoger op de geureigenschappen vettig, ranzig en was, paraffine in vergelijking met de monsters afkomstig uit nascheiding. Dit kan mede veroorzaakt worden door de hogere concentratie oliezuur in deze monsters. Er kunnen ook nog andere niet-geïdentificeerde stoffen een rol spelen in de geurbeleving.

- De scores van taak 2 zijn voor dezelfde geureigenschappen (vettig, ranzig; aards, muf; zeep, wasmiddel) lager dan in taak $1 \mathrm{~b}$ voor de geureigenschappen vettig, ranzig en aards, muf. Een lagere score betekent echter niet dat de monsters geen geur hebben. De scores van de geureigenschap zeep, wasmiddel zijn daarentegen hoger in taak 2 vanwege het gebruik van natronloog in de was-processen. 


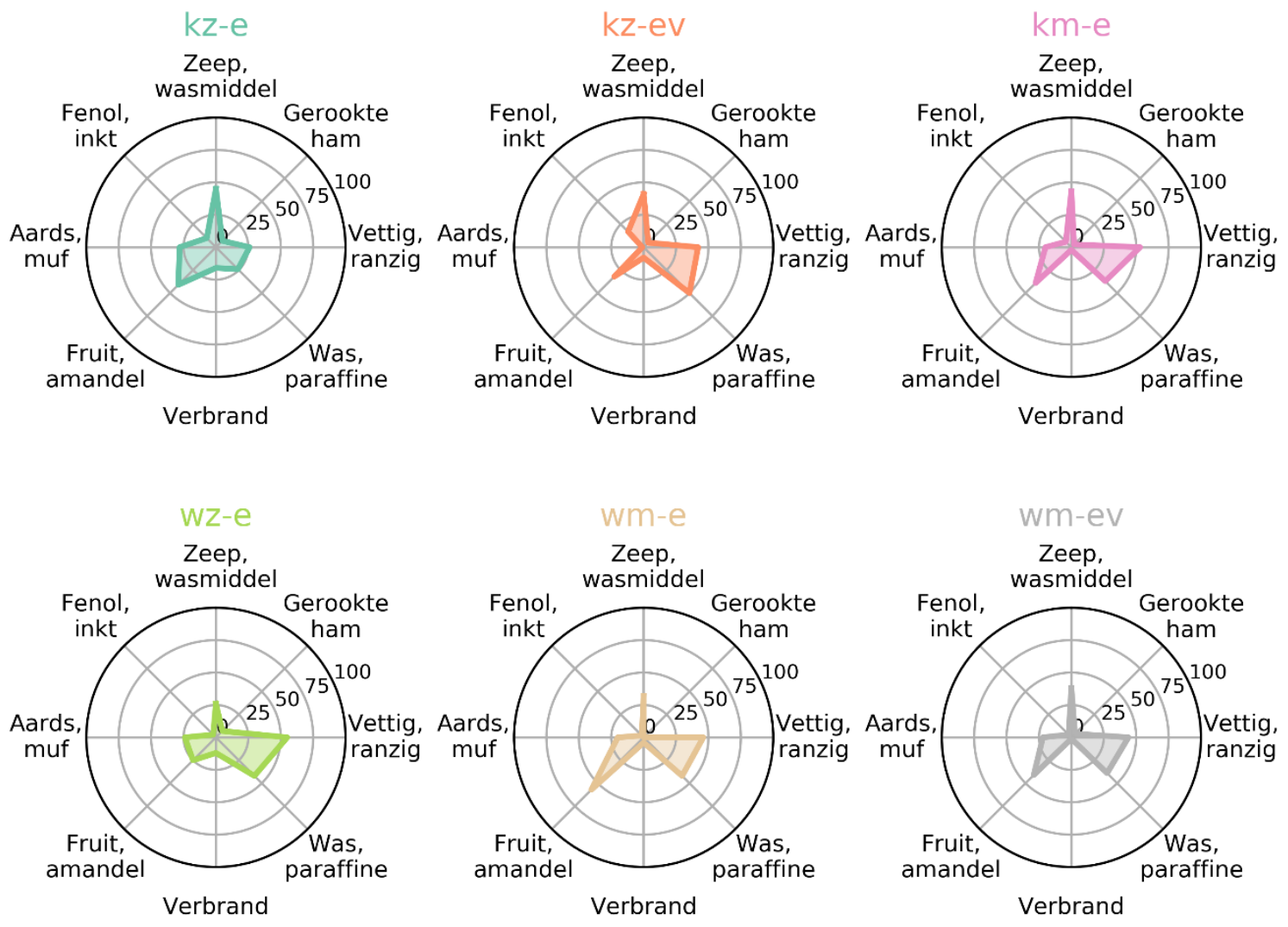

Figuur 12 Uitkomsten van de geurpanelanalyse voor de foliemonsters afkomstig uit bronscheiding die verschillende processtappen hebben ondergaan
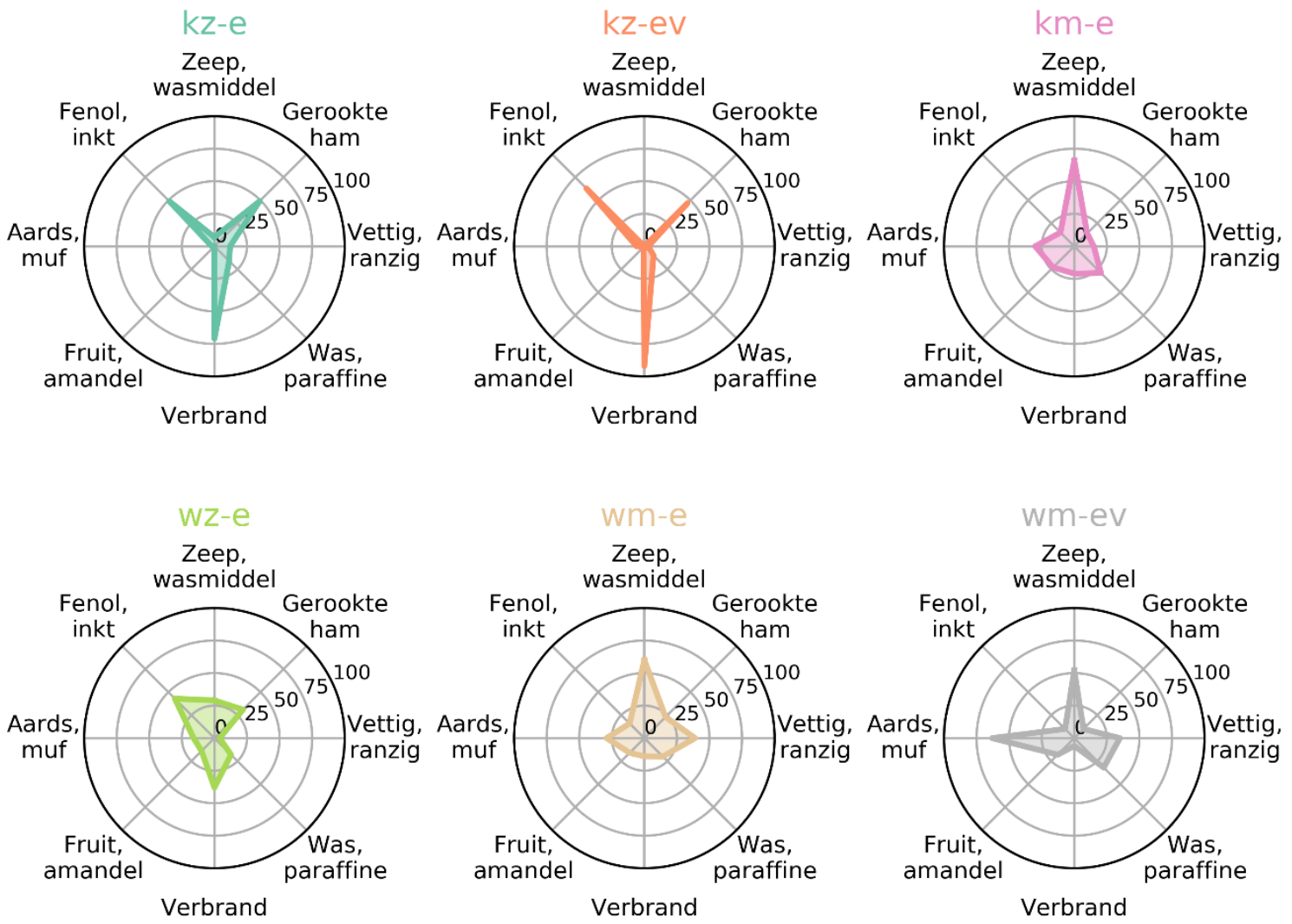

Figuur 13 Uitkomsten van de geurpanelanalyse voor de foliemonsters afkomstig uit nascheiding die verschillende processtappen hebben ondergaan 


\subsection{Deelconclusie}

In deze taak is het effect van verschillende bewerkingsprocessen op de moleculaire verontreiniging in monsters uit bron- en nascheiding onderzocht. Het moet nogmaals benadrukt worden dat deze taak gebaseerd is op de deelmonsters B2 en N2, en dat incidentele vervuilingen niet zijn uitgesloten in de eindconclusies. Voor deze taak is een willekeurig submonster van $3 \mathrm{~kg}$ genomen, mechanisch gerecycled en geëxtrudeerd. De parameters van deze mechanische recycling en extrusie zijn gevarieerd.

Er werd een forse variatie in de resultaten tussen monsters gevonden. Deze variatie tussen monsters blijkt onder andere uit de variatie in de massarendementen bij het recyclen. Dit suggereert variërende samenstellingen van de monsters in vervuilingen en daarmee ook in uiteindelijke moleculaire verontreiniging en geur.

Het extruderen had voor nagenoeg alle monsters een positief effect op de intensiteit en het aantal pieken in het gaschromatogram van de vluchtige stoffen, beide werden minder ten opzichte van die van de referentiemonsters uit taak $1 \mathrm{~b}$.

Ook in geurbeleving zijn er verschillen tussen de monsters afkomstig uit bron- en nascheiding gemeten. Het folie dat afkomstig was uit bronscheiding rook na recycling vettig, ranzig, amandel- en fruitachtig. Deze geur kon niet uit het folie worden verwijderd door heet te wassen met loog en te ontgassen met vacuüm tijdens de extrusie. Het folie dat afkomstig was uit nascheiding bleek na verhitting bij extrusie scherp fenolisch, inktachtig en verbrand te ruiken. Het ontstaan van deze geur kon wel worden voorkomen door warm te wassen of loog toe te voegen tijdens het wasproces. Hierna rook het nagescheiden folie zeepachtig, aards en muf. 


\section{Taak 3: Invloed van scheidingsgedrag op moleculaire verontreiniging}

Deze taak onderzoekt het effect van scheidingsgedrag op de moleculaire verontreiniging. Hiertoe worden er in verschillende wijken monsters genomen en geanalyseerd op de mate van moleculaire verontreiniging. Verwacht is dat zowel het scheidingsgedrag van de inwoners en het soort inzameling (brongescheiden PMD of plastic in restafval) van invloed is op de moleculaire verontreiniging in het ingezamelde plastic.

\subsection{Onderzoeksmethode}

Voor deze taak zijn drie wijken in de gemeente Utrecht geselecteerd: Binnenstad, De Meern en Lunetten. In de Binnenstad wordt kunststof ingezameld bij het restafval, tevens is er een lage participatiegraad in gescheiden groente- en fruitafval maar is er wel een hoge participatiegraad voor gescheiden inzameling van oud papier en karton. Ook in De Meern wordt het plastic ingezameld in het restafval maar is er in tegenstelling tot de Binnenstad een hoge participatiegraad in het gescheiden inzamelen van groente- en fruitafval. In Lunetten, daarentegen, wordt het plastic gescheiden ingezameld (bronscheiding) en is er een hoge participatiegraad voor zowel het gescheiden inzamelen van het groente- en fruitaval en oud papier en karton.

Van elke wijk (zie Tabel 9) is op de overslag in Utrecht het dagverse afval bemonsterd. Voor binnenstad en de Meern ging het om restafval op de AVR overslag; voor Lunetten is PMD afval op de overslag van Suez bemonsterd. Voor alle wijken is er één veel voorkomend type folie gekozen om uit het afval te sorteren om zo de wijken zo goed mogelijk te kunnen vergelijken. Voor deze taak is de Albert Heijn draagtas gekozen, omdat die in alle afvalstromen voldoende voorkwam. Het folie is gewassen met een basiswas, d.w.z. afschrobben in koud water met een afwasborstel, gevolgd door droogdeppen met absorberend papier. Alle monsters zijn geanalyseerd door middel van hexaanextractie en GC-MS analyse.

\begin{tabular}{llll} 
Tabel 9 & Overzicht van de monsters genomen voor taak 3. \\
\hline Monster & Wijk & Bemonsterdatum & Rest/PMD \\
\hline TK3-1 & Binnenstad & 2 juli 2019 & Restafval \\
\hline TK3-2 & De Meern & 8 juli 2019 & Restafval \\
\hline TK3-3 & Lunetten & 23 augustus 2019 & PMD-afval \\
\hline
\end{tabular}

\subsection{Resultaten en discussie}

Om de invloed van zowel het scheidingsgedrag van de inwoners als het soort inzameling (brongescheiden PMD of kunststof in restafval) op de moleculaire verontreiniging te kunnen bepalen zijn er monsters genomen van het afval uit drie verschillende wijken. Ook voor deze taak zijn de Albert Heijn draagtassen geselecteerd als veelvoorkomend product.

Tabel 10 laat de resultaten van de hexaanextractie voor de verschillende wijken zien. Opvallend is dat het geëxtraheerde gehalte voor de Binnenstad lager ligt dan voor De Meern en Lunetten. Echter leek het afval uit de Binnenstad vooral bedrijfsafval, waardoor het relatief schoon was. Daarentegen zat in het afval uit De Meern verfafval verwerkt. Ook is de ledigingsfrequentie van de Binnenstad twee keer per week versus één keer per week voor De Meern. Beide redenen zouden het relatief hoge percentage van het geëxtraheerde gehalte in de Meern kunnen verklaren. 
Tabel 10 Resultaten hexaanextractie voor Albert Heijn tassen uit ingezameld afval uit verschillende wijken.

\begin{tabular}{lll} 
Monster & Wijk & Gehalte extract (\%) \\
TK3-1 & Binnenstad & 3.9 \\
& & 3.8 \\
\hline \multirow{2}{*}{ TK3-2 } & De Meern & 5.5 \\
& & 5.1 \\
\hline \multirow{2}{*}{ TK3-3 } & Lunetten & 3.8 \\
& & 3.0 \\
\hline
\end{tabular}

Niet alleen in de hexaanextractie, maar ook in de GC-MS analyse van vluchtige stoffen aangetroffen in het folie valt op dat het monster TK3-2 meer vervuild is. Daarentegen zijn er nagenoeg geen verschillen in vluchtige stoffen te zien in de gaschromatogrammen van monster TK3-1 (Binnenstad, restafval) en TK3-3 (Lunetten, PMD-afval). Alle gaschromatogrammen zijn te vinden in Bijlage 4. Voor alle monsters is het aantal vluchtige stoffen te groot voor identificatie van de individuele organische verbindingen. Ook merkt het Fraunhofer instituut op dat er binnen een monster verschillen zijn aangetroffen (elke meting is uitgevoerd in drievoud).

De gaschromatogrammen van de gemiddeld tot niet vluchtige stoffen laten weinig verschillen zien tussen de wijken (zie Bijlage 4 voor alle chromatogrammen). Figuur 14 geeft de concentraties van de aangetroffen organische verbindingen voor de drie verschillende wijken weer. Het valt op dat er nagenoeg geen significante verschillen tussen de wijken zijn aangetroffen. Monster TK3-3 (Lunetten, PMD-afval) bevat een hogere concentratie oliezuur, echter is de fout in deze meting groter dan de gemiddelde waarde doordat oliezuur niet in alle deelmonsters is aangetroffen. Ook valt op dat het gaschromatogram van monster TK3-3 nog extra pieken bij een retentietijd van 15,3, 20,8 en 31,5 minuten laat zien. Deze zouden kunnen voortkomen uit de aanwezigheid van andere vetzuren uit voedselresten.

Het valt op dat in alle monsters een relatief hoge concentratie van de weekmaker DINCH is aangetroffen. Het zou kunnen dat deze weekmaker gebruikt wordt in de inkt van de bedrukking van de geanalyseerde Albert Heijn tassen.
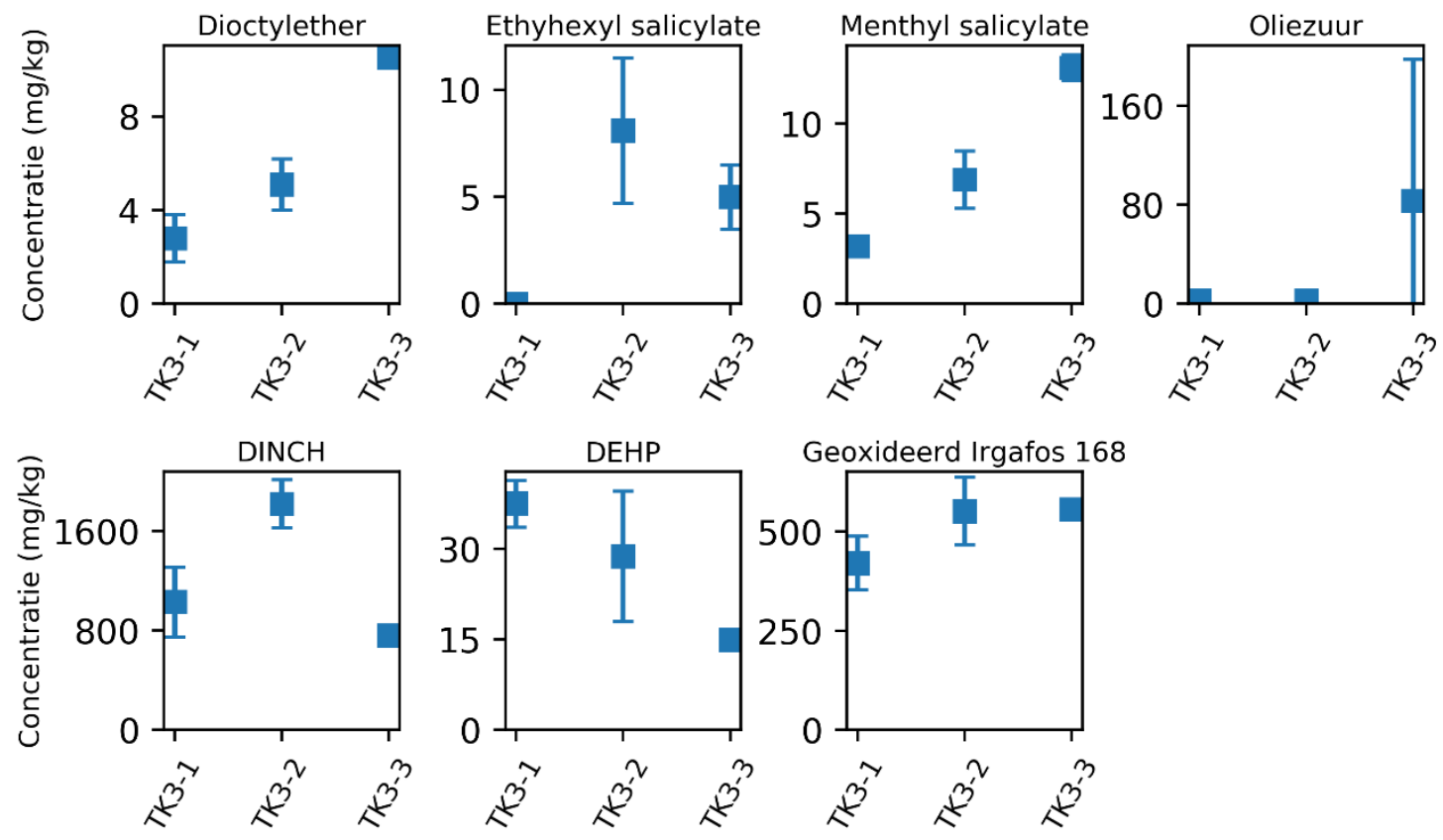

Figuur 14 Concentraties van aangetroffen stoffen (gemiddeld tot niet vluchtig) in de monsters geanalyseerd door middel van GC-MS 


\subsection{Deelconclusie}

Monster TK3-2 was duidelijk vervuild met verfresten wat het hogere hexaanextractie gehalte en de grotere aanwezigheid van vluchtige stoffen kan verklaren. Daarnaast bevatte monster TK3-3 een hogere concentratie van de plantaardige olie oliezuur. De verschillen in (moleculaire)

verontreinigingen zijn dan ook vooral toe te schrijven aan toevallige vervuilingen. We kunnen hier geen conclusies over de verschillende wijken en inzamelmethode uit trekken. 


\section{Taak 4: Invloed ledigingsfrequentie op moleculaire verontreiniging}

Naast de manier van inzamelen is ook de verwachting dat de ledigingsfrequentie invloed heeft op de moleculaire verontreiniging in kunststof folie. Deze taak onderzoekt het effect van de ledigingsfrequentie en manier van inzamelen op de moleculaire verontreiniging van LDPE-folie.

\subsection{Onderzoeksmethode}

Stukken goed herkenbaar virgin LDPE-folie (Oerlemans Plastics BV, Nederland) zijn verdeeld over twee mini-containers; één gevuld met restafval (ACV Ede, 24 juni 2019) en één gevuld met PMD-afval (ACV Ede, 24 juni 2019). In beide containers is de container laagsgewijs gevuld, dus een laag afval is afgewisseld met een laag LDPE-folie, en dat in meerdere lagen, zie Figuur 15.

De mini-containers (reguliere kliko's) hebben in de periode van 26 juni 2019 tot en met 24 juli 2019 buiten gestaan (Wageningen, Nederland). Initieel was het plan de containers in een geconditioneerde ruimte te zetten, maar door het vervuilde materiaal bleek dat helaas niet mogelijk. Elke week is er 10 $\mathrm{g}$ folie uit beide mini-containers gehaald voor hexaanextractie. In week 4 is er nog eens $50 \mathrm{~g}$ folie extra uit beide containers gehaald voor GC-MS analyse. Voor analyse zijn de stukken folie schoongemaakt met een basiswas; d.w.z. afschrobben in koud water met een afwasborstel, gevolgd door droogdeppen met absorberend papier.

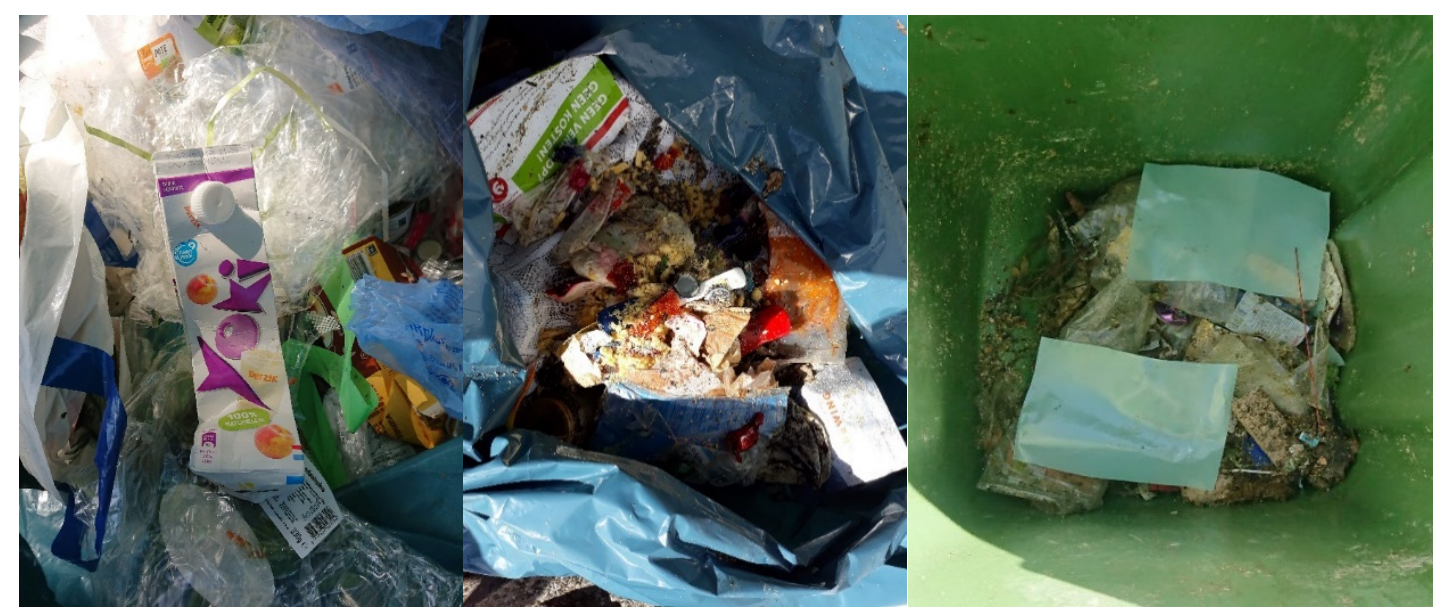

Figuur 15 Van links naar rechts; het PMD-afval, het restafval, en de stukken LDPE-folie in de mini-container

\subsection{Resultaten en discussie}

De invloed van de ledigingsfrequentie op de moleculaire verontreiniging in LDPE-folie is gesimuleerd door stukken LDPE-folie in mini-containers gevuld met rest- of PMD-afval te leggen. Elke week is een deel van de folie verwijderd om zo de ledigingsfrequentie te simuleren. Figuur 16 laat het geëxtraheerde gehalte van de LDPE-folie zien als functie van de tijd dat de folie in de containers heeft gelegen. Ook al lijkt het gehalte extract heel licht toe te nemen; er is geen significant verschil te zien in het geëxtraheerde gehalte voor zowel de tijd dat de folie in de container heeft gelegen alsmede het type afval (rest of PMD). 


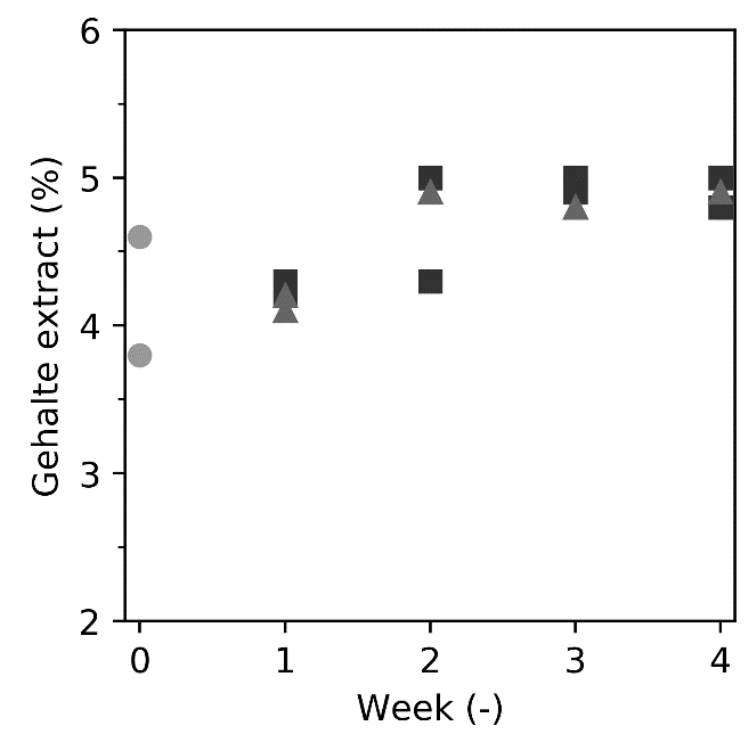

Figuur 16 Het in hexaan geëxtraheerde gehalte als functie van de gesimuleerde ledigingsfrequentie. Week 0 betreft het startmateriaal (ronde symbolen, 0 ). Er is geen verschil in het extractie gehalte voor zowel de ledigingsfrequentie als het soort container (restafval: driehoekige symbolen $\triangle$ of PMD: vierkante symbolen, $\square$ )

Ondanks dat er geen verschil in het geëxtraheerde gehalte gevonden is, is er wel een visueel verschil tussen de LDPE-folies. Figuur 17 laat foto's zien van de LDPE-folies na vier weken in een container met respectievelijk PMD- en restafval. Na de basiswas met koud water is het duidelijk dat er meer verkleuring in de LDPE-folies uit de restafval container is opgetreden. Verontreinigingen kunnen echter in zeer lage concentraties al verkleuring opleveren, waardoor dit wordt overschaduwd door overige hexaan oplosbare componenten en dus niet meetbaar is met hexaanextractie. De mate van verkleuring van de folies neemt toe met de tijd in de container, en lijkt dus omgekeerd evenredig met de ledigingsfrequentie
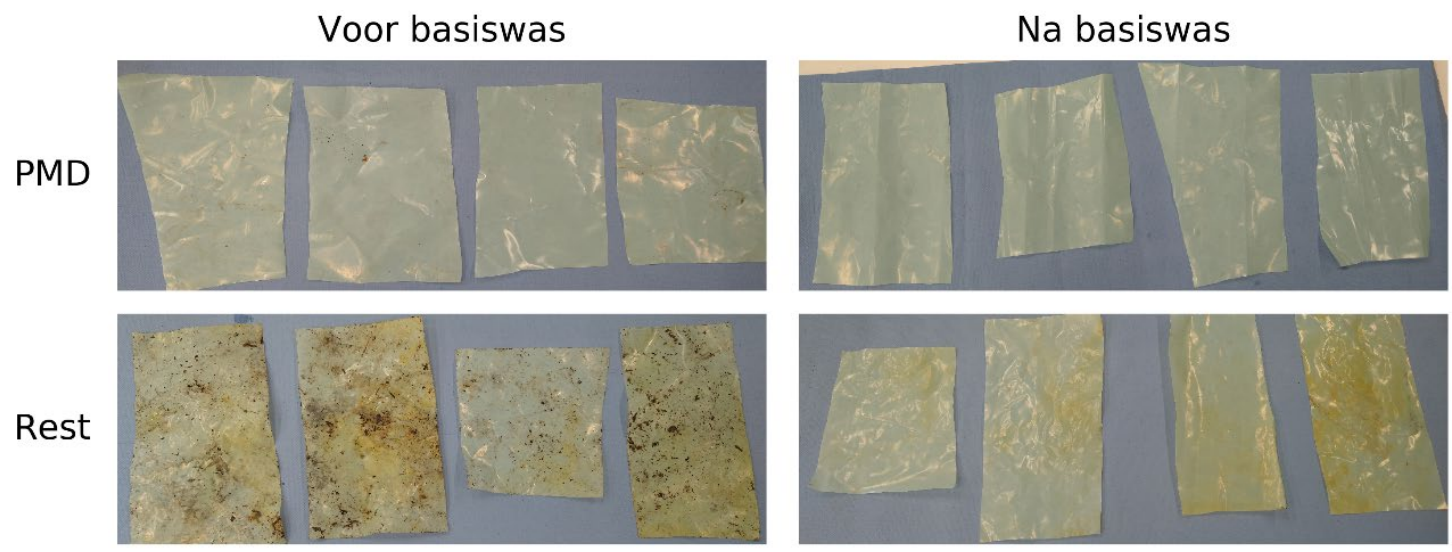

Figuur 17 Foto's van de LDPE-folies na vier weken in respectievelijk een PMD-container en een restafvalcontainer voor en na een basiswas met koud water 
In tegenstelling tot de monsters van de eerste drie taken (Albert Heijn draagtassen), laten de gaschromatogrammen van de LDPE-folie gebruikt in taak 4 een stuk minder vluchtige stoffen zien (zie Figuur 18). De chromatogrammen van de LDPE-folies die in de containers hebben gelegen lijken erg op elkaar, maar zijn wel verschillend ten opzichte van het chromatogram van het startmateriaal. De belangrijkste verschillen in de chromatogrammen zijn grijs gearceerd in Figuur 18.In zowel het gaschromatogram van het folie dat 4 weken in contact is geweest met PMD als dat van het folie dat 4 weken in contact is geweest met restafval zien we 3 a 4 extra grote pieken en meer hele kleine piekjes. Een aantal van deze pieken kon worden geïdentificeerd. Zo is de piek met een retentietijd van 7.8 minuten afkomstig van limoneen (geur- en smaakstof), van 9.3 minuten decamethylcyclopentasiloxaan (cosmetica, haarlak), van 9.5 minuten waarschijnlijk van dodeceen, en van 10.7 minuten waarschijnlijk van een vertakt alkaan. Kortom, er zijn 3 à 4 belangrijke vluchtige verbindingen bijgekomen in beide soorten folies, maar deze verbindingen verschillen wel tussen de folies.

Opvallend is dat voor zowel het folie dat vier weken in contact is geweest met PMD-afval als met restafval de intensiteit van de pieken met een retentietijd van 9,5 of hoger afneemt. Dit effect is het meest significant bij het folie dat in contact is geweest met restafval. Dit betekent dat de concentratie van deze minder vluchtige stoffen afneemt. Het kan zijn dat deze stoffen worden afgebroken tot andere stoffen, of dat ze uit het materiaal verdwijnen door migratie of oplossen.

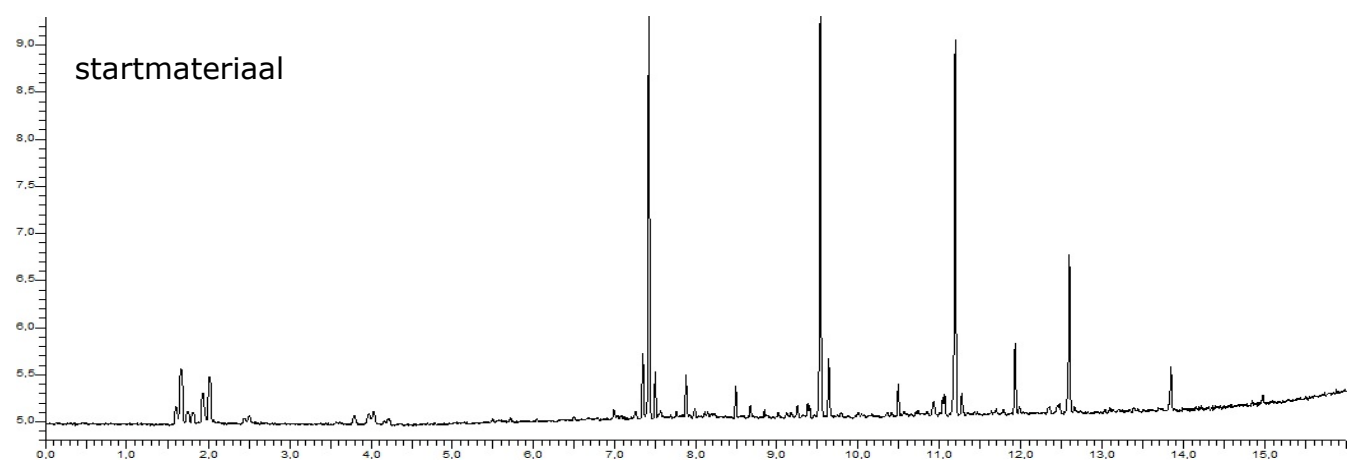

Na 4 weken PMD
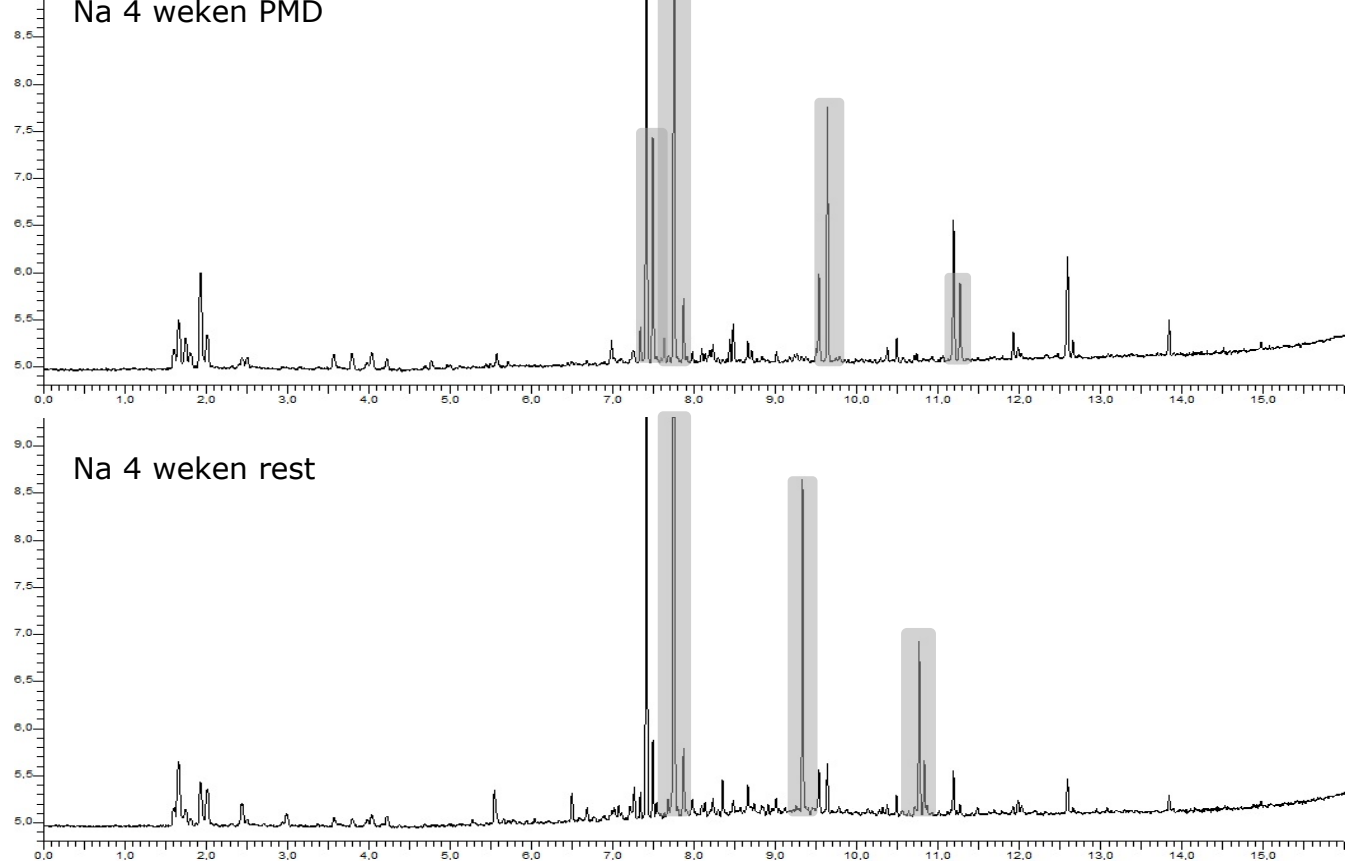

Figuur 18 Gaschromatogram van de vluchtige stoffen voor het startmateriaal, na vier weken in een PMD-container en na 4 weken in een restafvalcontainer. De belangrijkste verschillen in de chromatogrammen zijn grijs gearceerd 
De gaschromatogrammen van de gemiddeld tot niet vluchtige stoffen laten voor alle LDPE-folies een serie pieken zien die behoren tot een reeks alkenen, zie Figuur 19. Deze reeks alkenen, met lengte C16 tot C38, zijn afkomstig van PE-oligomeren, oftewel korte stukjes PE. Figuur 20 laat de concentraties van, onder andere, deze PE-oligomeren zien. Over het algemeen zijn er geen (significante) verschillen in concentraties tussen de folies aangetroffen. Opmerkelijkerwijs is de gemeten concentratie van de minder zware alkenen (hexadeceen tot triaconteen, $C_{16}-C_{30}$ ) in het folie dat in contact is geweest met het restafval iets lager dan in de folie die in contact is geweest met PMD en ook ten opzichte van de beginsituatie. Vermoedelijk metaboliseren de in het restafval aanwezige micro-organismen deze minder zware alkenen. Deze langketenige alkenen hebben overigens een geringe geurintensiteit, dus het is niet waarschijnlijk dat dit opmerkelijke verschil zal leiden tot een verschil in geur.

Naast het verschil in alkeen concentratie zijn er ook na vier weken voor beide container typen organische verbindingen aangetroffen die niet aanwezig waren in het startmateriaal. Dit is te zien in Figuur 19. Het gaschromatogram van de LDPE-folie die in contact is geweest met PMD-folie laat een klein extra piekje zien op een retentietijd van 16,5 minuten, deze piek is waarschijnlijk afkomstig van hexadecaanzuur methylester (o.a. een van de meest voorkomende vetzuren in cellen van zoogdieren). De LDPE-folie die in contact is geweest met restafval heeft meer organische verbindingen opgenomen. Het gaschromatogram laat extra pieken zien met retentietijden van 19,7, 21,4 en 23,0 minuten. De bijbehorende stoffen konden niet worden geïdentificeerd. De piek bij 23,0 minuten zou afkomstig kunnen zijn van erucamide, een kunststofadditief dat de wrijving van PE met verwerkingsapparatuur verlaagt. Echter is deze piek maar in één submonster aangetroffen.
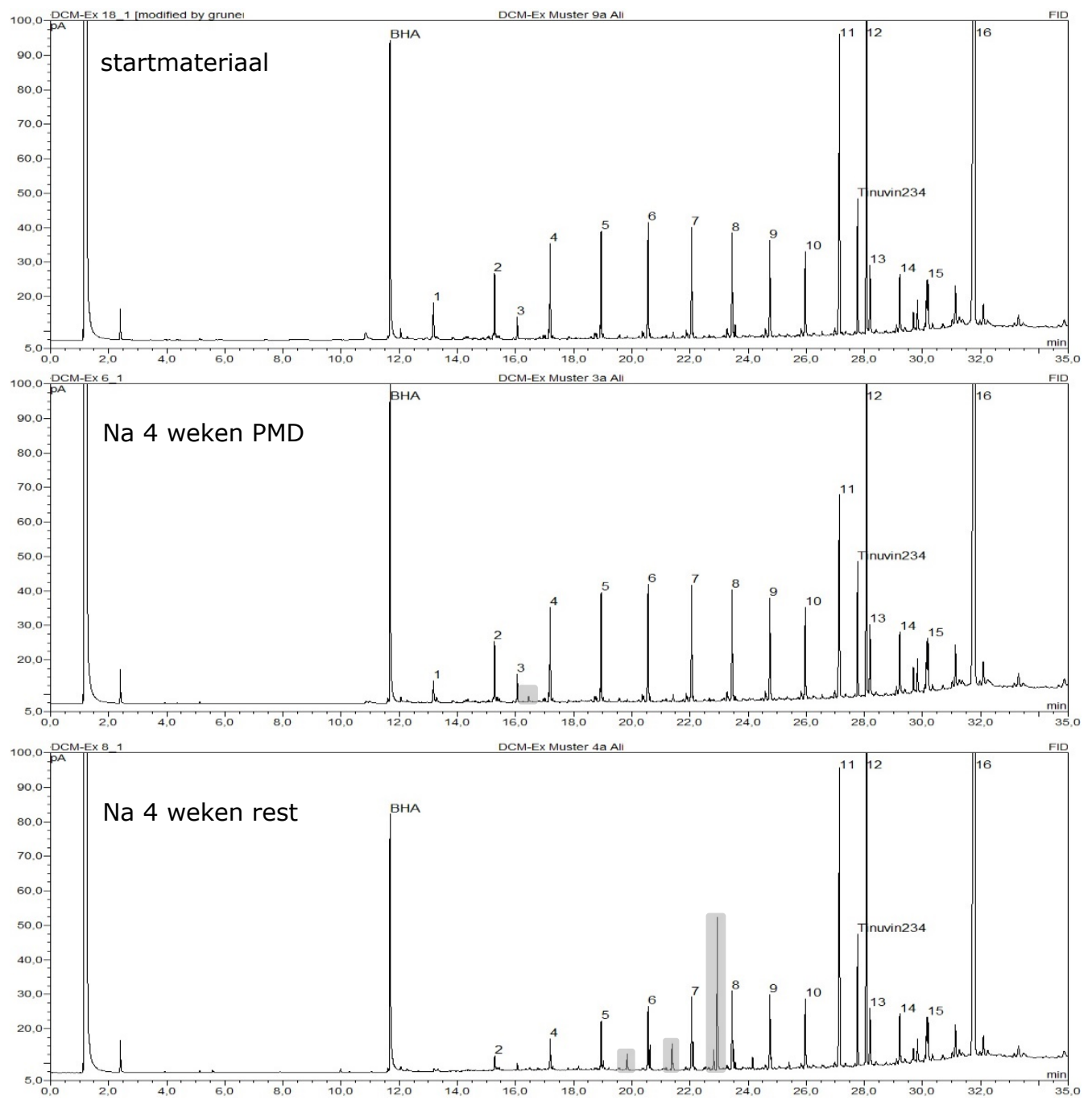

Figuur 19 Gaschromatogram voor de gemiddelde tot niet vluchtige stoffen van het startmateriaal, na vier weken in een PMD-container en na vier weken in een restcontainer. De belangrijkste verschillen in de chromatogrammen zijn grijs gearceerd 

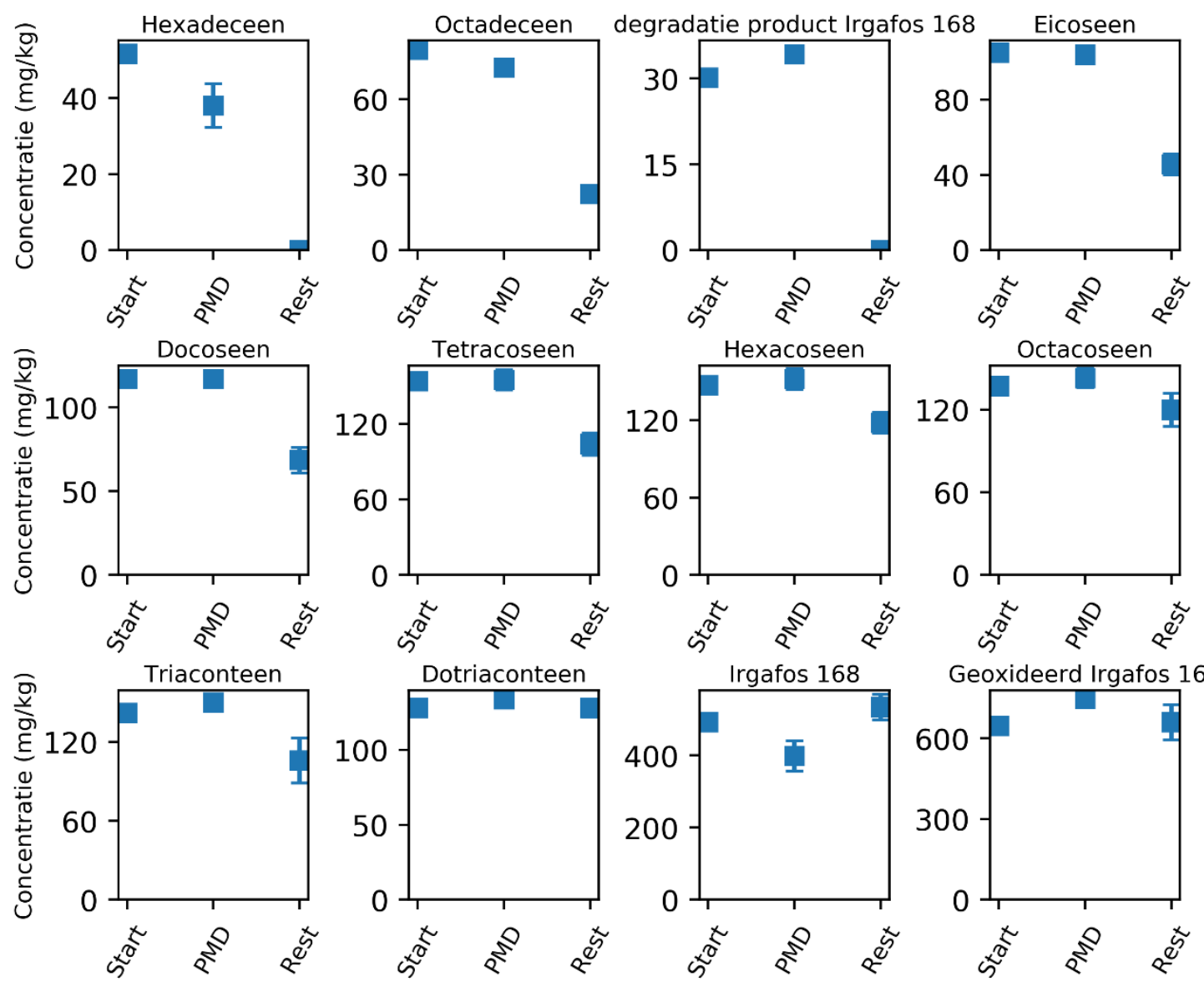

Geoxideerd Irgafos 168
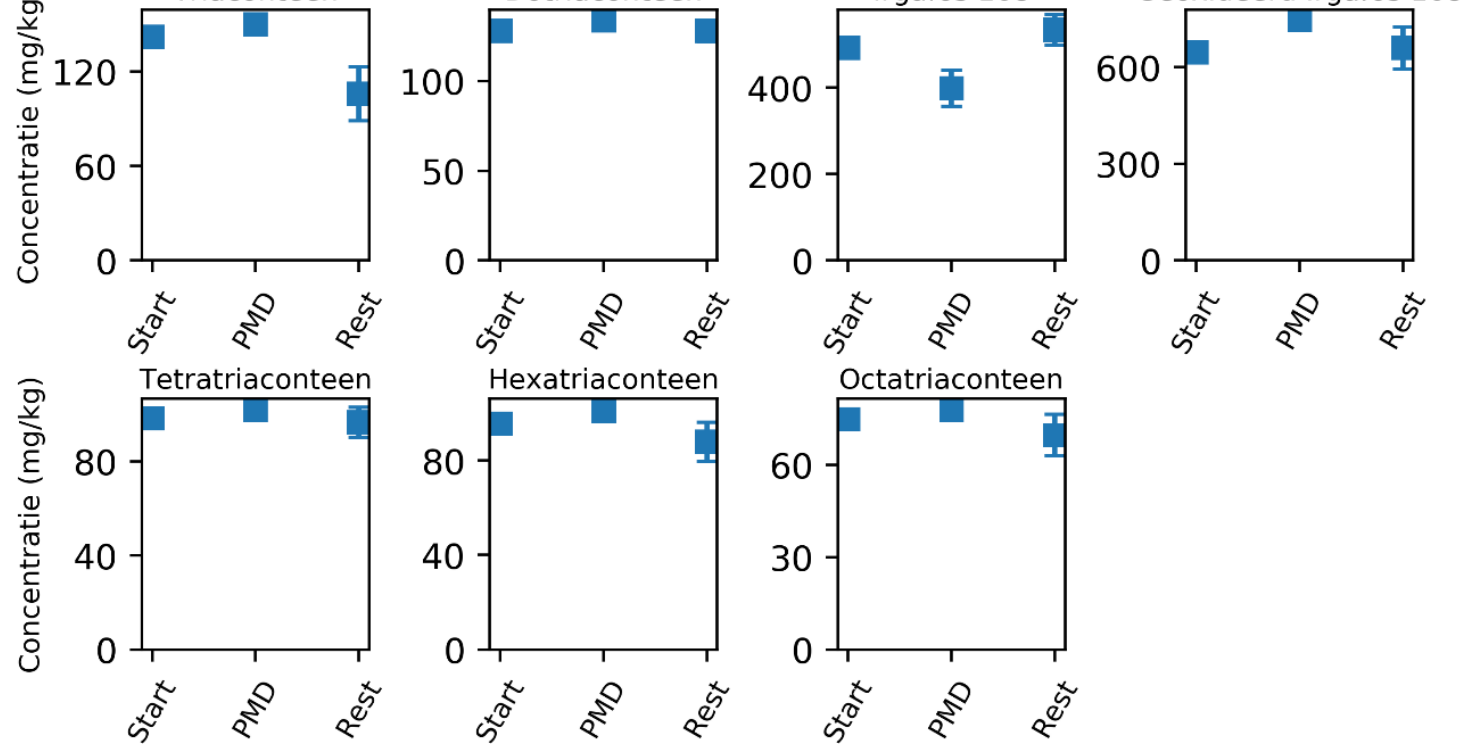

Figuur 20 Concentraties van aangetroffen stoffen (gemiddeld tot niet vluchtig) in de monsters geanalyseerd door middel van GC-MS 


\subsection{Deelconclusie}

Deze taak onderzocht twee onderzoeksvragen: i) heeft de ledigingsfrequentie invloed op de moleculaire verontreiniging en ii) heeft de manier van inzamelen invloed op de moleculaire verontreiniging.

\section{Ledigingsfrequentie}

Uit de hexaanextractie blijkt dat het geëxtraheerde gehalte niet wordt beïnvloed door de ledigingsfrequentie. Echter is ook gebleken dat hexaanextractie niet nauwkeurig genoeg is om de moleculaire verontreiniging te kunnen bepalen. Zonder aanvullend GC-MS onderzoek kan deze vraag dan ook niet beantwoord worden.

\section{Manier van inzamelen}

Het virgin LDPE-folie uit deze taak bevat zowel minder vluchtige als minder gemiddeld tot niet vluchtige stoffen ten opzichte van de Albert Heijn draagtassen uit de eerdere taken (wat logisch is, gezien de achtergrond van de draagtassen), wat de analyse minder gecompliceerd maakt. Zowel de LDPE-folie die in een PMD-container als de LDPE-folie die in een restcontainer heeft gelegen bevatten additionele pieken in de gaschromatogrammen van de vluchtige stoffen en de chromatogrammen van de gemiddeld tot niet vluchtige stoffen. De LDPE-folie afkomstig uit de PMD container bevat additionele pieken van onder andere limoneen (geur- en smaakstof) en dodeceen. De LDPE-folie afkomstig uit de restcontainer bevat additionele pieken van onder andere limoneen, decamethylcyclopentasiloxaan (cosmetica, haarlak) en een vertakt alkaan. Het effect van deze pieken op de geur van het materiaal is niet onderzocht.

De LDPE-folie afkomstig uit de PMD-container heeft in het gaschromatogram van de gemiddeld tot niet vluchtige stoffen minder additionele pieken ten opzichte van het startmateriaal in vergelijking met de LDPE-folie die in de restcontainer heeft gelegen. Het monster dat vier weken in de PMD-container heeft gelegen bevatte één extra piek ten opzichte van het startmateriaal, en is geïdentificeerd als zeer waarschijnlijk hexadecaanzuur methylester (o.a. een van de meest voorkomende vetzuren in cellen van zoogdieren). Na vier weken in een restcontainer bevatte het monster drie extra pieken, deze konden echter niet worden geïdentificeerd. Één van deze pieken is ook alleen in één submonster aangetroffen.

Men kan voorzichtig concluderen dat er minder verontreiniging van gemiddeld tot niet vluchtige stoffen optreedt in een PMD-container ten opzichte van een restcontainer. De foto's van de LDPE-folie na vier weken bevestigen deze conclusie omdat duidelijk meer verkleuring te zien is bij het materiaal uit de restcontainer.

Er kan echter niet worden geconcludeerd of de aanwezigheid van deze additionele pieken ook van invloed is op de geur van het materiaal. Sommige geurstoffen zijn al ruikbaar bij zeer lage concentraties terwijl andere stoffen bij hoge concentraties nog nauwelijks waarneembaar zijn. 


\section{Discussie}

In dit hoofdstuk zullen de verschillen tussen bron- en nascheiding bediscussieerd worden. Niet alleen worden de verschillen in moleculaire verontreiniging besproken, maar ook andere aspecten zoals massarendement en kwaliteit van het recyclaat wordt meegenomen.

\subsection{Massarendement}

Bij een technische vergelijking tussen bron- en nascheiding is zowel het massarendement als de kwaliteit van recyclingproducten relevant. Voorts kan deze vergelijking in massarendement tussen beide meerstaps-processen pas plaatsvinden als de materiaalstromen onderling vergelijkbaar zijn geworden. Eerder is al beredeneerd dat het eerste halffabricaat waarbij beide materiaalstromen onderling vergelijkbaar zijn het gewassen maalgoed is [Pretz et al. 2009]. Immers de ingezamelde materialen en de nagescheiden concentraten zijn onvergelijkbaar in materiaalsamenstelling en in percentage aanhangend vocht en vuil. En ook de sorteerproducten uit bron- en nascheiding zijn onvergelijkbaar in de percentages aanhangend vocht en vuil.

Voor de kwantitatieve vergelijking is het relevant om te weten hoeveel gewassen maalgoederen er uit bron- of nascheiding kunnen worden verkregen. Voor bronscheiding is hierbij het gekozen inzamelsysteem ten opzichte van het inzamelgebied en de daaruit volgende participatiegraad bepalend. In inzamelgebieden met laagbouw kunnen hoge participatiegraden worden bereikt met PMD inzameling via een haalsysteem met mini-containers. Het scheidingsgedrag van burgers wordt hiermee de bepalende factor en deze blijkt maximaal ongeveer $70 \%$ te zijn, oftewel participerende burgers werpen ongeveer $70 \%$ van de kunststof verpakkingen in de PMD bak en $30 \%$ in de restafvalbak. In inzamelgebieden met hoogbouw is het - los van het scheidingsgedrag - al veel lastiger om hoge participatiegraden te bereiken, deze blijven zo rond 30-40\% steken [Thoden van Velzen et al. 2019].

Voor nascheiding is het ontwerp van de nascheiding-installatie in relatie tot de samenstelling van het ingaande huisvuil en de uitvoeringswijze (beladingsgraad en de gelijkmatigheid van belading) bepalend voor het massarendement. Het grootste verlies aan kunststofverpakkingen in een goed functionerende nascheiding-installatie vindt plaatst bij de zeven. De kleinste zeefmaat varieert tussen de 35 en de $65 \mathrm{~mm}$. Kleine verpakkingen en kleine kunststofverpakkingscomponenten komen in het fijngoed terecht en kunnen niet nagescheiden worden (in principe kunnen die bij bronscheiding door de consument wel apart gehouden worden, ze worden dan voor een groot gedeelte afgescheiden in de sorteerinstallatie bij de zeef en ballistische scheider). Dit beperkt het maximaal mogelijke nascheidingrendement voor kunststofverpakkingen uit gemengd huishoudelijk restafval tot ongeveer $70 \%$. Hierna volgen voor beide productstromen het sorteer- en mechanische recyclingproces. Het sorteerrendement voor nascheiding-concentraat is iets hoger dan voor PMD, omdat het nascheidingconcentraat al een keer door NIR-machines is gesorteerd en folies al grotendeels verwijderd zijn. Het mechanisch recyclingrendement voor de sorteerproducten uit nascheiding is juist lager dan die uit bronscheiding vanwege de hogere gehaltes aan aanhangend vocht- en vuil [Thoden van Velzen et al. 2017]. Dit laatste werd in taak 2 van dit onderzoek herbevestigd. Beide effecten heffen elkaar op, zodat de maximale massarendementen (in termen van hoeveelheid gewassen maalgoederen) die voor beide recyclingsystemen haalbaar zijn ook vergelijkbaar zijn. Voor inzamelgebieden waar het lastig is om hoge participatiegraden te bereiken met PMD-inzameling, zoals hoogbouwwijken, kan er daarom met nascheiding meer gewassen maalgoed worden geproduceerd omdat de participatiegraad daar laag is voor PMD inzameling. 


\subsection{Kwaliteit}

Naast de geproduceerde hoeveelheid aan gewassen maalgoederen is ook de kwaliteit van deze producten relevant bij een technische vergelijking. Die kwaliteit wordt met meerdere parameters beschreven die voor verschillende afnemers relevant kunnen zijn. Hieronder zijn deze kwaliteitsparameters gegroepeerd:

- Polymere verontreiniging (mechanische en optische eigenschappen).

- Deeltjesverontreiniging (mechanische en optische eigenschappen).

- Gemiddelde ketenlengte en breedte van de verdeling (verwerkbaarheid).

- Kleur.

- Moleculaire verontreiniging (migratie, geur).

Zoals in de inleiding al werd beschreven is naar 4 van de 5 van deze kwaliteitsparameters al onderzoek gedaan en is de doelstelling van dit onderzoek om te verkennen of er verschil is de laatst overgebleven kwaliteitsparameter: de moleculaire verontreiniging.

De moleculaire verontreiniging in gerecycled folie is uitgebreid onderzocht in dit rapport. Er is voor folie gekozen omdat dit materiaal door zijn gunstige oppervlak-volume verhouding en chemische aard veel geurstoffen zal opnemen. Folie is daarmee een worst-case. De moleculaire verontreiniging in folie-materiaal en in gewassen folie-snippers is op meerdere manieren onderzocht. In de onderzochte foliemonsters bleken vijf hoofdsoorten moleculaire verontreinigingen voor te komen, zie Tabel 11.

Tabel 11 De soorten moleculaire verontreinigingen in LDPE-folie.

\begin{tabular}{|c|c|c|c|}
\hline Soort & Soort moleculen & $\begin{array}{l}\text { Relatieve } \\
\text { concentratie }\end{array}$ & Geur activiteit \\
\hline $\begin{array}{l}\text { Oligomeren en } \\
\text { afbraakproducten }\end{array}$ & Homologe reeksen van alkanen en alkenen & Hoog & Nauwelijks \\
\hline Kunststofadditieven & $\begin{array}{l}\text { Antioxidanten (Irgafos) } \\
\text { Hulpstoffen (calcium stearaat) }\end{array}$ & Beperkt & Niet tot nauwelijks \\
\hline $\begin{array}{l}\text { Additieven uit bedrukking } \\
\text { en etiketten }\end{array}$ & $\begin{array}{l}\text { Weekmakers (DEHP, etc.) } \\
\text { MOSH oplosmiddelen }\end{array}$ & Matig & Niet tot nauwelijks \\
\hline $\begin{array}{l}\text { Incidentele verontreiniging } \\
\text { met productresten }\end{array}$ & $\begin{array}{l}\text { Sterk wisselend, bijvoorbeeld: } \\
+ \text { verfresten (pinenen) } \\
+ \text { levensmiddelen (oliezuur) } \\
+ \text { spierpijncrème (menthyl salicylate) } \\
+ \text { geurstoffen (limoneen) } \\
+ \text { fenolen uit drukinkt }\end{array}$ & Hoog & $\begin{array}{l}\text { Wisselend tussen } \\
\text { nauwelijks en hoog }\end{array}$ \\
\hline $\begin{array}{l}\text { Microbiologische } \\
\text { metabolieten en } \\
\text { afbraakproducten }\end{array}$ & $\begin{array}{l}\text { Sterk verschillend: } \\
+\quad \text { Geosmine, 2-methyl-isoborneol, 2,4,6- } \\
\text { trichlooranisool, etc. }^{1} \\
+ \text { Korte vetzuren als boterzuur } \\
+ \text { methylsulfiden en methylaminen }{ }^{1}\end{array}$ & Zeer laag & Zeer hoog \\
\hline
\end{tabular}

1 Deze stoffen zijn niet in dit onderzoek geïdentificeerd, maar zijn wel in vergelijkbare gepubliceerde onderzoeken geïdentificeerd. Het is redelijkerwijs aan te nemen dat deze stoffen ook in de monsters uit dit onderzoek aanwezig zijn.

In zowel bron- als nagescheiden foliemateriaal komen al deze vijf hoofdsoorten moleculaire verontreiniging voor. Verreweg het grootste deel van de aangetroffen moleculaire contaminanten zijn de oligomeren en afbraakproducten. Deze vormen in het gaschromatogram van de gemiddeld tot niet vluchtige stoffen een kenmerkend patroon van hoge pieken met steeds dezelfde tussenafstand. Dit patroon verschilt voor verschillende soorten LDPE-folie, zodat het ene materiaal een homologe reeks van alkanen laat zien en het andere materiaal een homologe reeks van alkenen, etc. In het geval metingen worden verricht aan een type folie (zoals gedaan is in taak 4) wordt een relatief overzichtelijk patroon waargenomen in het gaschromatogram. Wanneer er echter wordt gemeten aan een mengsel van folies (zoals in de sorteerproducten van taak 1 en 2) dan zien we in het gaschromatogram een heel druk patroon ontstaan van deels overlappende homologe reeksen, wat het opsporen van andere moleculen bemoeilijkt. In dit onderzoek konden een aantal van deze pieken 
worden geïdentificeerd met de GC-MS technologie, van andere pieken kon alleen met zekerheid worden gesteld dat het koolwaterstoffen zijn.

Andere onderzoekers hebben dezelfde patronen gevonden in het gaschromatogram voor HDPE en LDPE monsters uit inzameling en recycling. Bovendien hebben ze aangetoond dat deze verbindingen een zeer geringe geur-intensiteit hebben [Strangl. et al. 2017, 2018 en 2019; Cabanes et al. 2020].

In kunststoffolies worden meerdere kunststofadditieven gebruikt als antioxidanten en bijvoorbeeld antislip-middelen. In bijna alle gaschromatogrammen wordt antioxidant Irgafos 168, geoxideerde Irgafos 168 en soms zelfs degradatieproducten hiervan waargenomen. Een antislipmiddel als calcium stearaat wordt niet aangetroffen, omdat een dergelijk zout niet vluchtig genoeg is voor gaschromatografie. Wel worden mogelijk afgeleide stoffen als hexadecaanzuur (stearinezuur) aangetroffen. Dergelijke additieven worden uiteraard in zowel bron- als nagescheiden monsters aangetroffen. Zover bekend heeft het antioxidant geen geur. Mogelijk ruikt het hexadecaanzuur licht zeepachtig.

Additieven uit bedrukkingen en etiketten werden regelmatig geïdentificeerd en aangetroffen in monsters uit zowel bron- als nascheiding. Zo konden in verschillende monsters weekmakers als DEHA, DEHP, ATBC, DEHT en DINCH worden geïdentificeerd. Zover ons bekend zijn deze moleculen niet of nauwelijks geur-actief en zullen dus ook niet of nauwelijks bijdragen aan de geur.

In zowel bron- als nagescheiden foliemonsters kwamen incidentele verontreinigingen voor met productresten. Dit is een buitengewoon diverse groep aan contaminanten die ineens in een monster duidelijk aanwezig kan zijn. Tijdens dit onderzoek zijn er incidentele contaminanten aangetroffen die goed in verband kunnen worden gebracht met productresten als zonnebrandcrème, spierpijn-crème, verf, olijfolie, etc. Aan de hand van dit onderzoek kan er geen verschil worden aangetoond in incidentie tussen bron- en nascheiding-monsters. Vermoedelijk komen deze verontreinigingen regelmatig voor in beide materiaalstromen. Veel van de incidentele verontreinigingen zijn geur-actief en zullen dus ook bijdragen aan de geur van het foliemonster. Waarschijnlijk vormt het wel of niet voorkomen van deze incidentele verontreinigingen de grootste bron van spreiding in de geur-analyses van foliemonsters.

Tenslotte zijn er de microbiologische metabolieten en afbraakproducten. Dit zijn moleculen die vaak in zeer lage concentraties voorkomen maar door de sterke geurintensiteit toch de geur van een monster kunnen domineren. Het GC-MS onderzoek in deze studie heeft ze niet kunnen aantonen, omdat de gaschromatogrammen te sterk werden overheerst door de oligomeren en polymere afbraakproducten. Wel werden er kenmerkende geurverschillen tussen monsters aangetoond, die naar alle waarschijnlijkheid verband houden met deze omzettingsproducten.

Uit analyse door een geurpanel bleek dat foliemateriaal uit bron- en nascheiding in het algemeen anders ruikt. Daarbij moet worden opgemerkt dat er wel spreiding is in de geur-panel-scores tussen vergelijkbare monsters. Onze voorzichtige interpretatie hiervan is dat microbiologische omzettingsproducten [Strangl et al., 2017 en 2018]. er voor zorgen dat bron- en nagescheiden foliemonsters in de basis anders ruiken, maar dat er variatie in de geur is door het toevallig voorkomen van incidentele verontreiniging.

\section{Invloed van de recyclingwijze}

De basisgeur van met bronscheiding ingezameld foliemateriaal met PMD is vettig, ranzig, wasachtig, amandelachtig en fruitachtig. Vettige en ranzige geuren worden in verband gebracht met vetzuren met korte ketens (boterzuur, pentaanzuur en isomeren). Dit zijn microbiologische omzettingsproducten van vetten en levensmiddelenresten. Terwijl wasachtige geuren meer passen bij PE-oligomeren, en amandel- en fruitachtige geuren meer passen bij productresten van cosmetica en lichaamsverzorgingsproducten. De basisgeur van uit PMD verkregen foliemateriaal blifft constant en is onafhankelijk van de recyclingwijze, dus deze geur kan niet verwijderd worden door te wassen met warm water, warm loog water en te vacumeren bij de extrusie. De piek-intensiteiten in de gaschromatogrammen dalen iets ten gevolge van het wassen in warm water en het vacuümontgassen in de extruder, echter de basisgeur verandert niet. Spaans en Duits onderzoek met HDPE en LDPE uit bronscheiding rapporteren hetzelfde [Strangl. et al. 2017, 2018 en 2019; Cabanes et al. 
2020]. De aangepaste recyclingwijze laat de concentratie aan oligomeren, afbraakproducten en additieven dalen die nauwelijks geuractief zijn, terwijl de concentratie van de geur-actieve stoffen onvoldoende daalt om het materiaal minder te laten ruiken.

De basisgeur van nagescheiden foliemateriaal is aards en muf. Na verhitting tijdens extrusie verandert dit in scherp, fenolisch, inktachtig en verbrand, wanneer met koud water zonder loog gewassen wordt. Deze geur ontstaat niet nadat het folie gewassen is met warm water of loog en daarna geëxtrudeerd, dan ruikt het nagescheiden foliemateriaal juist weer zeep- en wasmiddel-achtig, aards en muf. De opmerkelijke waarneming dat koud gewassen nagescheiden kunststoffolie scherp verbrand, fenolisch en inktachtig ruikt en na warm wassen deze typische geur er niet is, doet vermoeden dat de verantwoordelijke geur-actieve moleculen lage molecuulmassa's hebben en relatief polair van aard zijn. Waardoor deze geur-actieve moleculen relatief makkelijk kunnen worden verwijderd door warm te wassen. Dit kunnen relatief kleine moleculen zijn als fenol, guaiacol eventueel aangevuld met een lijst aan methylsulfiden en methylamines die vrijkomen bij de microbiologische afbraak van eiwitbevattende levensmiddelen. Fenol en guaiacol zouden afkomstig kunnen zijn uit bedrukkingen van oud-papier, de methylsulfiden en methylaminen uit de afbraak van levensmiddelenresten. Zodoende is het niet onlogisch dat een dergelijk scherpe geur zijn oorsprong vindt in contact met restafval. Dit is nog niet eerder door andere groepen gerapporteerd, maar kan verband houden met de nascheidingwijze die in Nederland wordt gevolgd.

Als het nagescheiden folie warm is gewassen met loog ruikt het dus zeep- en wasmiddelachtig, aards en muf. De geur van zeep- en wasmiddelen kan in verband worden gebracht met vrije vetzuren met een relatief lange ketenlengte. De aards en muffe geur wordt in verband gebracht met microbiologische metabolieten als geosmine, 2-methyl-isoborneol en 2,4,6-trichlooranisool.

De resultaten van dit onderzoek geven aan dat over het geheel gezien de verontreiniging van bron- en nagescheiden foliemateriaal beide aanzienlijk zijn. Hexaanextracties geven aan dat dit varieert tussen de 3 en de $7 \%$. Echter zijn deze percentages een optelsom van degradatieproducten, additieven, inkten, moleculaire verontreinigingen, etc. Bovendien treden forse incidentele verschillen op in de (moleculaire) verontreiniging van beide materialen. De geur wordt bepaald door slechts een beperkt aantal moleculen die in de grote groep moleculaire contaminanten niet of nauwelijks opvallen bij een GC-MS-analyse, maar wel de materialen een karakteristieke geur geven.

De gevonden geurverschillen kunnen relevant zijn in het geval het foliemateriaal weer als verpakkingsfoliemateriaal wordt hergebruikt. De mate van acceptatie van de geur zal dan afhangen van het product dat verpakt wordt. Is dit tuinaarde of compost, dan is waarschijnlijk weinig probleem met beide geuren.

\section{Invloed inzame/wijze en ledigingsfrequentie}

De invloed van de inzamelwijze op de moleculaire vervuiling aanwezig in één soort LDPE verpakking (de Albert Heijn draagtas) kon niet worden aangetoond. Incidentele vervuiling (olijfolie en verfresten) overschaduwde de resultaten bij 2 van de 3 monsters. Met de kennis van nu was het beter geweest om het folie van de drie wijken op te werken tot gewassen maalgoed en dit door een geurpanel te laten beoordelen, en niet slechts een heel beperkt monster te onderzoeken.

De invloed van de inzamelwijze (via PMD of via restafval) en ledigingsfrequentie is ook onderzocht met schoon LDPE folie dat met beide afvalstromen in contact is gebracht. Hieruit bleek dat de inzamelwijze invloed heeft op de verkleuring van het folie en de moleculaire verontreiniging gemeten met GC-MS. Het schone folie dat in contact is met restafval neemt iets meer op. De mate van verkleuring doet laten vermoeden dat deze opname groeit met de blootstellingstijd, dus omgekeerd evenredig is met de ledigingsfrequentie. Er kan evenwel niet worden vastgesteld dat deze blootstelling ook resulteert in een duidelijkere geur. In vervolgonderzoek is het advies de folies te laten beoordelen door een geurpanel voor en na wassen, en ook op meerdere momenten tussentijds te meten.

\section{Recent Spaans en Duits onderzoek}

Nadat het onderzoek was afgerond en het rapport werd geschreven, verscheen een artikel over het verschil in geur en geurstoffen tussen Spaans bron- en nagescheiden LDPE folie [Cabanes et al. 2020]. Hieruit bleek dat Spaans nagescheiden LDPE folie meer kaasachtige, zweetachtige en fecale geureigenschappen bezit dan Spaans brongescheiden LDPE folie. Dit terwijl het Spaans brongescheiden 
LDPE folie meer muf en aards rook dan het Spaans nagescheiden LDPE folie. Dit verschilt met de geurwaarneming in dit rapport van Nederlands folie uit bron en nascheiding; dit wordt waarschijnlijk veroorzaakt door een andere samenstelling van het Spaanse restafval en de hogere temperaturen. Hierbij speelt mogelijk een rol dat in delen van Spanje het niet is toegestaan om gebruikt toiletpapier via het toilet door te spoelen, dit wordt dan toegevoegd aan het restafval.

Een groot deel van de geur-actieve verbindingen in het Spaanse onderzoek konden worden geïdentificeerd door middel van een combinatie van GC-MS en GC-olfactometrie. De geurstoffen die aardse, muffe geur veroorzaken in gebruikte LDPE folie zijn onder andere: 2-methoxy-3,5dimethylpyrazine, 2-methylisoborneol, 2,4,6-trichlooranisool, geosmine en patchouli alcohol. Waarschijnlijk zijn dit voornamelijk microbiologische metabolieten, alleen patchouli alcohol is een bekende productrest, namelijk een geurstof die wordt toegepast in parfums, cosmetica, etc. Geurstoffen die verantwoordelijk zijn voor de kaasachtige, zweetachtige geur van gebruikte LDPE folie zijn een serie van vetzuren met een korte ketenlengte (boterzuur, etc.). Geurstoffen die verantwoordelijk zijn voor de fecale geur zijn p-cresol, indol en skatol.

Geurstoffen die verantwoordelijk zijn voor de zeepachtige geur van gebruikte LDPE folie zijn octanal, nonanal, $\mathrm{Y}$-decalacton, $\mathrm{Y}$-undecalacton, $\mathrm{Y}$-dodecalacton en dodecaanzuur.

Geurstoffen die verantwoordelijk zijn voor de fruitachtige en bloemige geur van gebruikte LDPE folie zijn verschillende terpenen als 1,8-cineol, a-damascon, a-isomethyljonon en $\beta$-jonon.

Verder bleek ook uit dit onderzoek dat de geuren uit de gebruikte LDPE-folies slechts beperkt konden worden verwijderd door warm te wassen.

Waarschijnlijk zijn grosso modo dezelfde soort geurmoleculen aanwezig in Nederlands en Spaans gebruikte LDPE folie. Toch zijn er verschillen, want het Nederlands nagescheiden foliemateriaal rook niet fecaal, terwijl dit wel het geval was voor het Spaanse nagescheiden foliemateriaal. Waarschijnlijk wordt dit veroorzaakt door een andere samenstelling van het Spaanse restafval ten opzichte van het Nederlandse restafval en de hogere temperaturen.

Recent Duits onderzoek naar de recycling van brongescheiden folie en meng-polyolefine meldt vergelijkbare geuren voor de gerecyclede plastics als in dit rapport. De kunststoffen werden met koud water gewassen en konden niet verwijderd worden. Door extrusie van deze kunststoffen ontstond een nieuwe geur van gebrande koffie die aan 2-methylheptaan-2-thiol kon worden toegeschreven [Strangl et al., 2020].

\subsection{Eindoordeel}

Kunststofverpakkingen nemen moleculaire verontreinigingen op tijdens gebruik, inzameling, sortering en recycling. Een deel van deze moleculaire vervuiling is geur-actief, oftewel heeft een duidelijke geur die het hergebruik kunnen belemmeren. Vanwege de verschillen in inzameling en de andere materialen waarmee kunststofverpakkingen dan in contact komen, ontstaan ook geurverschillen. Zodoende geuren kunststofverpakkingen die via PMD worden ingezameld anders dan kunststofverpakkingen die worden nagescheiden. Het recyclingproces kan slechts beperkt de geur verminderen. Wel is het belangrijk bij nagescheiden materiaal met warm water of loog te werken. Desalniettemin blijven beide soorten kunststoffen geuren en zal het van de toepassing afhangen welke geur minder storend is.

Dit verschil in moleculaire verontreiniging tussen bron- en nagescheiden materiaal is samengevat in een totaaloverzicht van de verschillen tussen beide materialen, zie Tabel 12. 


\section{Tabel 12 Verschillen en overeenkomsten tussen bron- en nascheiding.}

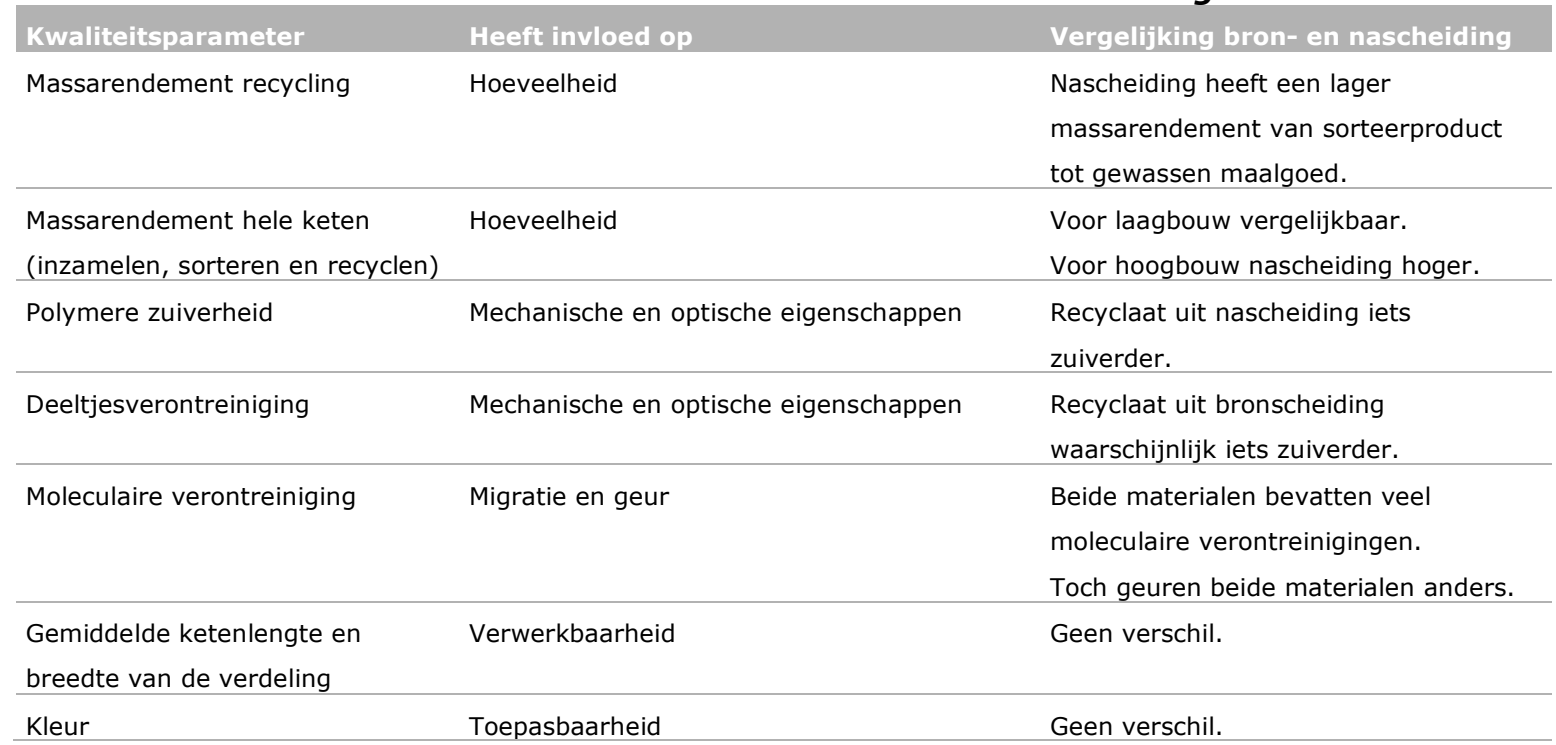

Dit onderzoek heeft zich beperkt tot het sorteerproduct Folie met de daarin aanwezige flexibele verpakkingen omdat dit als een worst-case geldt. Grofweg kan soortgelijk gedrag worden verwacht van de sorteerproducten PE en PP waarin respectievelijk voornamelijk vormvaste verpakkingen van HDPE flessen en PP schalen aanwezig zijn. Dit zijn kunststoffen met een vergelijkbare chemie als die van de folies (voornamelijk LDPE) maar met een minder hoge oppervlakte-volume-verhouding waardoor dezelfde geurstoffen zullen oplossen alleen iets trager. Overigens geldt hetzelfde ook voor het sorteerproduct Mix omdat dit hoofdzakelijk uit PE en PP verpakkingen bestaat. Tenslotte bestaat het sorteerproduct PET (DKR 325 of 328-1) voornamelijk uit PET flessen. Dit kunststof neemt nauwelijks geurmoleculen op en die worden in het uitgebreide recyclingproces voor PET flessen ook nog verwijderd [Welle 2011]. Zodoende gelden de conclusies van deze studie voor het (voornamelijk LDPE) folie-product algemener voor alle gerecyclede kunststoffolies uit bron- en nascheiding. De rPET-producten zullen niet tot nauwelijks een waarneembare geur hebben. De rPE, rPP en MIX-gerecyclede kunststoffen afkomstig uit bron en nascheiding zullen anders ruiken, waarschijnlijk vergelijkbaar als bron- en nagescheiden folie, maar vermoedelijk minder sterk. Bij de huidige toepassingen van deze gerecyclede kunststoffen is dit niet storend.

Dit onderzoek heeft zich gericht op de moderne recyclingwijze van foliemateriaal dat streeft naar circulair hergebruik van het folie. Opgemerkt moet worden dat er in Europa nog recyclingbedrijven bestaan die op een minder geavanceerde wijze folie nu verwerken, zoals de droog-mechanische verwerking. Omdat hierbij het foliemateriaal ongewassen wordt verhit en gekneed, is het waarschijnlijk dat dan het nagescheiden materiaal scherp verbrand gaat ruiken (net als bij de experimenten in dit rapport met koud gewassen en geëxtrudeerd materiaal). Voor de recycling van nagescheiden folie is het dus belangrijk dat er een moderne recyclingwijze wordt gevolgd.

Tenslotte nog een algemene opmerking over de keuze voor bron- of nascheiding. Dit rapport behandelt de technische verschillen tussen de teruggewonnen kunststoffen. In de praktijk van gemeenten, inzameldiensten en andere belanghebbenden spelen echter nog een heleboel andere belangen die meegewogen moeten worden. Hierbij kan gedacht worden aan financiële middelen voor de aanleg van faciliteiten van brongescheiden inzameling (brengbakken) als inzamelvoertuigen ten opzichte van de financiële verplichtingen die voortkomen uit een huisvuilverwerkingscontract bij een nascheider. Daarnaast heeft de keuze invloed op het aantal voertuigbewegingen in de stad voor de afvalinzameling, verkeersdoorstroming en ook ongediertebestrijdingsbeleid. Zodoende een algemene oproep aan diegenen die dit rapport willen gebruiken als ondersteuning van hun beleidskeuzes om niet alleen de technische facetten van die keuze te beoordelen, maar ook de financiën en de indirecte beleidseffecten mee te wegen. 


\section{Conclusies}

De moleculaire verontreinigingen in kunststoffolie dat via bronscheiding of nascheiding teruggewonnen en gerecycled is, is verkennend onderzocht om beter te begrijpen welke invloed de terugwinningswijze (bron of na) heeft op de kwaliteit van het gerecyclede PE kunststoffolie. Hierbij is bewust voor kunststoffolie gekozen vanwege de hoge oppervlakte-volume-verhouding en de chemie van het folie waardoor er veel geurstoffen in oplossen.

Deze moleculaire verontreiniging geeft geur aan kunststof en beperkt de toepasbaarheid voor levensmiddelenverpakkingsmateriaal (in verband met migratie). Deze verontreiniging is in vier taken met drie technieken onderzocht.

- Hexaanextractie.

- Gaschromatografie gekoppeld aan massaspectrometrie (GC-MS) van vluchtige stoffen via desorptie en van minder vluchtige stoffen via extractie.

- Geurpanel.

Hexaanextractie bleek meetwaarden met een forse variatie op te leveren, waardoor er geen duidelijk verschil tussen monsters kon worden waargenomen. De extracten, folies en geëxtraheerde folies werden met infrarood spectroscopie onderzocht. Hieruit bleek dat het grootste deel van het extract bestond uit koolwaterstoffen, de oligomeren van het kunststof en de afbraakproducten. Opgeloste geurstoffen zijn in veel lagere concentraties aanwezig in het folie en ook niet aantoonbaar met infrarood spectroscopie binnen het mengsel van oligomeren.

Met GC-MS technieken werden complexe gaschromatogrammen verkregen met heel veel pieken en dus heel veel verschillende verbindingen. Hiervan kon slechts een klein deel worden geïdentificeerd. De meeste geïdentificeerde verbindingen waren oligomeren van $\mathrm{PE}$, de homologe reeksen van alkanen en alkenen. Daarnaast werden enkele weekmakers en een antioxidant aangetroffen. Slechts in een enkel geval kon een geurstof worden geïdentificeerd. De weekmakers zijn waarschijnlijk afkomstig van de bedrukking en de etiketten. In een paar gevallen werden bovenop deze toch complexe patronen ook nog grote pieken van incidentele verontreinigingen aangetroffen die in verband konden worden gebracht met specifieke productresten: olijfolie, spierpijn-crème, zonnebrandcrème, verfresten. De complexiteit van de gaschromatogrammen kon worden verminderd door niet gerecycled kunststoffolie te bestuderen (dat uit een mengsel van verschillende soorten folie bestaat) maar door nieuwe stukken folie aan de afvalstroom toe te voegen en deze te bestuderen.

Met een geurpanel kon het folie het beste worden onderzocht. Op basis van dit onderzoek kunnen de onderzoeksvragen als volgt worden beantwoord.

Is er verschil in moleculaire verontreiniging tussen bronscheiding en nascheiding?

Er zijn weinig verschillen aangetroffen tussen bron- en nascheiding in het soort moleculen en concentraties dat kon worden geïdentificeerd door middel van GC-MS. Daarentegen, is er wel een verschil gevonden in de geur van gerecycled kunststoffolie dat afkomstig is uit bronscheiding of uit nascheiding. Folie-materiaal dat afkomstig is uit bronscheiding ruikt vooral ranzig, nootachtig. Foliemateriaal dat afkomstig is uit nascheiding ruikt vooral aards en muf. Het zal van de toepassing waar dit materiaal voor in aanmerking komt, afhangen welke geur als minder wenselijk wordt ervaren.

Wat is de invloed van de recyclingwijze op de moleculaire verontreiniging?

Het folie dat afkomstig was uit bronscheiding rook na recycling vettig, ranzig, amandel- en fruitachtig. Deze geur kon niet uit het folie worden verwijderd door heet te wassen met loog en te ontgassen met vacuüm tijdens de extrusie. Het folie dat afkomstig was uit nascheiding bleek na verhitting bij extrusie scherp fenolisch, inktachtig en verbrand te ruiken. Het ontstaan van deze geur kon wel worden voorkomen door warm te wassen of loog toe te voegen tijdens het wasproces. Hierna rook het nagescheiden folie zeepachtig, aards en muf. Deze verschillende geuren van het gerecyclede kunststoffolie-materiaal zijn te danken aan hele lage concentraties geur-actieve moleculen die in het folie zijn geabsorbeerd en die er met de geteste recycling technieken niet of nauwelijks uit te halen zijn. Dit zal de toepasbaarheid van deze materialen (zowel afkomstig uit bron- en nascheiding) op dit 
moment beperken tot die toepassingen waar dit niet storend is. Denk bijvoorbeeld aan: vuilniszakken, tuinaardezakken, compostzakken, vijverfolie, landbouwfolie, etc.

Welk effect heeft scheidingsgedrag op de kwaliteit van het recyclaat?

Deze vraag kan op basis van dit onderzoek niet goed beantwoord worden. Een aanbeveling voor vervolgonderzoek is met grotere monsters werken, zodat toevallige verontreinigingen minder invloed hebben op de resultaten.

Welk effect heeft blootstellingsduur aan ander afval op de moleculaire verontreiniging?

Vastgesteld is dat een langere blootstelling aan restafval het nagescheiden kunststoffolie sterker kan verkleuren. Het gaschromatogram van folie dat vier weken in contact is geweest met restafval is iets complexer dan dat van het folie dat vier weken in contact is geweest met PMD-materiaal, wat aangeeft dat er iets meer moleculen uit het restafval zijn geabsorbeerd dan uit het PMD-materiaal. Of dit ook leidt tot een andere geur is niet onderzocht. Op basis van dit onderzoek kan geen uitspraak gedaan worden over het effect van ledigingsfrequentie op de moleculaire verontreiniging.

Op basis van dit verkennende onderzoek lijkt er geen significant verschil te zijn tussen moleculaire verontreiniging van gerecycled materiaal teruggewonnen uit bron- en nascheiding. Beide materialen geuren, maar op een andere manier. De uiteindelijke keuze voor een inzamelsysteem zal afhangen van de bredere context waarin veel factoren een rol spelen: niet alleen de technische aspecten, maar ook economische en sociaal maatschappelijke factoren. 


\section{Literatuur}

Burnley S, Coleman T. 2018. The environmental and financial benefits of recovering plastics from residual municipal waste before energy recovery. Waste Management. 79: 79-86. https://doi.org/10.1016/j.wasman.2018.07.034

Cabanes A, Strangl M, Ortner E, Fullana A, Buettner A. 2020. Odorant composition of post-consumer LDPE bags originating from different collection systems. Waste Management. 104; 228-238.

Camacho W, Karlsson S. 2001. Quality-determination of recycled plastic packaging waste by identification of contaminants by GC-MS after microwave assisted extraction (MAE). Polymer Degradation and Stability 71; 123-134. DOI: http://dx.doi.org/10.1016/S0141-3910(00)00163-4 .

Cimpan C, Maul A, Jansen M, Pretz T, Wenzel H. 2015. Central sorting and recovery of MSW recyclable materials: A review of technological state-of-the-art, cases, practice and implications for materials recycling J Environ. Manage. 156: 181-199. http://dx.doi.org/10.1016/j.jenvman.2015.03.025

European Union, Directive 2011 / 10, Off. J. Eur. Union L12/1.

Jansen M, Thoden van Velzen EU, Ferreira B, Pretz, T., 2013. Recovery of plastics from municipal solid waste in materials recovery facilities. In: Fourteenth International Waste Management and Landfill Symposium 30 September e 4 October 2013. S. CISA Publisher. Margherita di Pula, Cagliari, Italy.

Leenaars, Y., Boer de, E., 2017. Samenstelling ingezameld kunststof/PMD verpakkingen -het effect van inzamelsystemen, Learning Centre Kunststofverpakkingsafval, Utrecht. https://www.nedvang.nl/uploads/LCKVARapportage_Samenstelling_kunststof_PMD_verpakkingen. pdf.

Robertson GL, Food Packaging, 2012 CRC Press, Boca Raton.

Połomka J, Jędrczak A. 2019. Efficiency of waste processing in the MBT system. Waste Management 96: 9-14. https://doi.org/10.1016/j.wasman.2019.06.041

Pretz T, Pikhard O, Gillner R, 2009. Onderzoek naar de mogelijkheden voor het hergebruik van kunststof afkomstig uit huishoudelijk restafval [Uit het Duits vertaald], RWTH IAR Aachen.

Strangl M, Fell T, Schlummer M, Maeurer A, Buettner A. Characterization of odorous contaminants in post-consumer plastic packaging waste using multi-dimensional gas chromatographic separation coupled with olfactometric resolution. J Sep Sci. 2017;40:1500-1507. doi: $10.1002 /$ jssc. 201601077

Strangl M, Schlummer M, Maeurer A, Buettner A. Comparison of the odorant composition of postconsumer high density polyethylene waste with corresponding recycled and virgin pellets by combined instrumental and sensory analysis. Journal of Cleaner Production 181 (2018) 599-607. https://doi.org/10.1016/j.jclepro.2018.01.137

Strangl M, Ortner E, Buettner A. Evaluation of the efficiency of odor removal from recycled HDPE using a modified recycling process. Resources, Conservation \& Recycling 146 (2019) 89-97. https://doi.org/10.1016/j.resconrec.2019.03.009

Strangl M, Ortner E, Fell T, Ginzinger T, Buettner A. Odor characterization along the recycling process of post-consumer plastic film fractions. Journal of Cleaner Production 260 (2020) 121104 
Thoden van Velzen EU, Jansen M, Brouwer MT, Feil A, Molenveld K, Pretz T, 2016. Efficiency of recycling post-consumer plastic packages. In: Proceedings of the 32th International Conference of the Polymer Processing Society 25-29 July, Lyon, AIP Conference Proceedings 1914, 170002 (2017), https://doi.org/10.1063/1.5016785

Thoden van Velzen U, Brouwer M, Molenveld K, Whitepaper Kwaliteit van gerecyclede huishoudelijke kunststofverpakkingen, mei 2018: https://www.wur.nl/upload_mm/7/d/0/49608658-9258-45e3b1c4-f267a6e4ac83_20180518\%20White\%20paper\%20kunststofkwaliteit.pdf

Thoden van Velzen EU, Brouwer MT, Feil A. 2019. Collection behaviour of lightweight packaging waste by individual households and implications for the analysis of collection schemes. Waste Management 89: 284-293. https://doi.org/10.1016/j.wasman.2019.04.021

Trulli E, Ferronato N, Torretta V, Piscitelli M, Masi S, Mncini I. 2017. Sustainable mechanical biological treatment of solid waste in urbanized areas with low recycling rates. Waste Management 71: 556564. https://doi.org/10.1016/j.wasman.2017.10.018

Welle, F., 2011. Twenty years of PET bottle to bottle recycling-An overview. Resour. Conserv. Recycl. 55 (11), 865-875. 


\section{Bijlage 1 Additionele data taak 1a}

\section{Infrarood spectra van alle monsters}

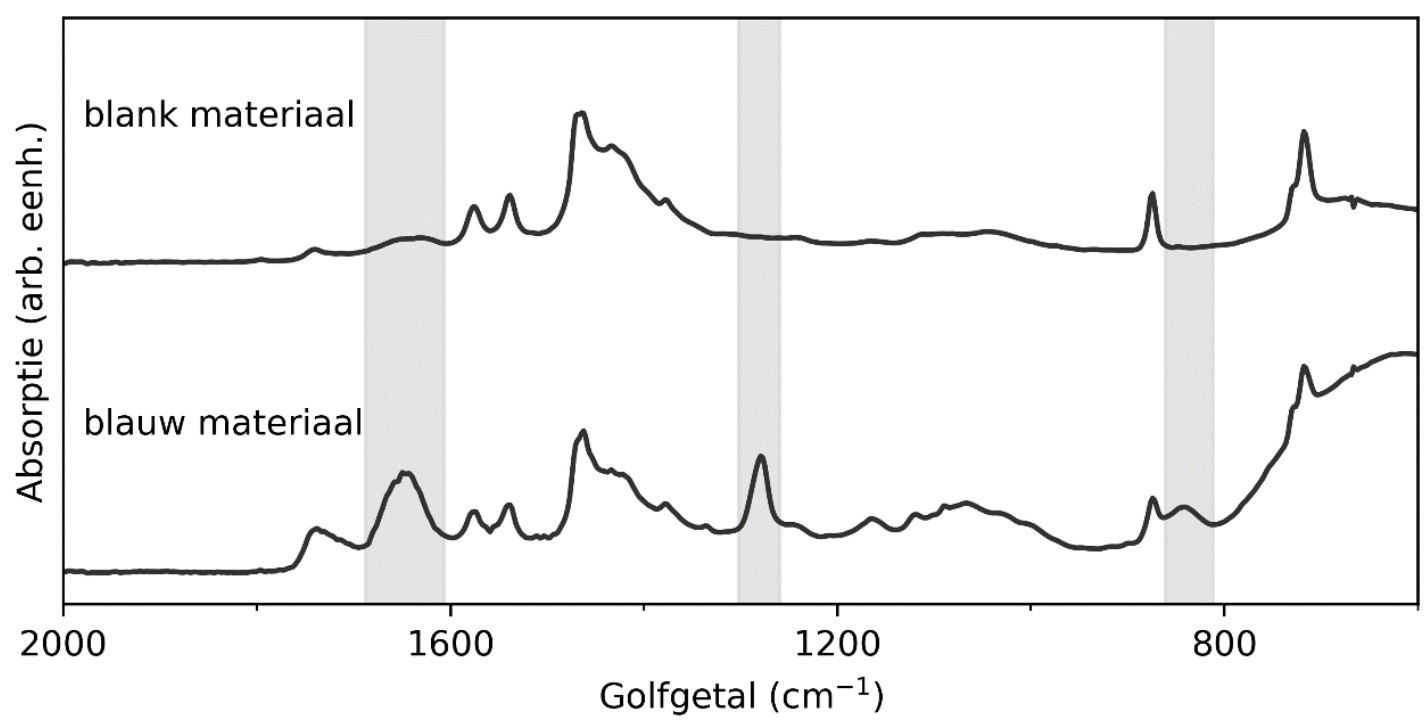

Figuur 21 Vergelijking van het infrarood spectrum van het blanke en blauw gekleurde deel van de Albert Heijn tassen voor de hexaanextractie. De grijs gearceerde gebieden geven pieken weer die kunnen worden toegeschreven aan de bedrukking op de Albert Heijn tassen

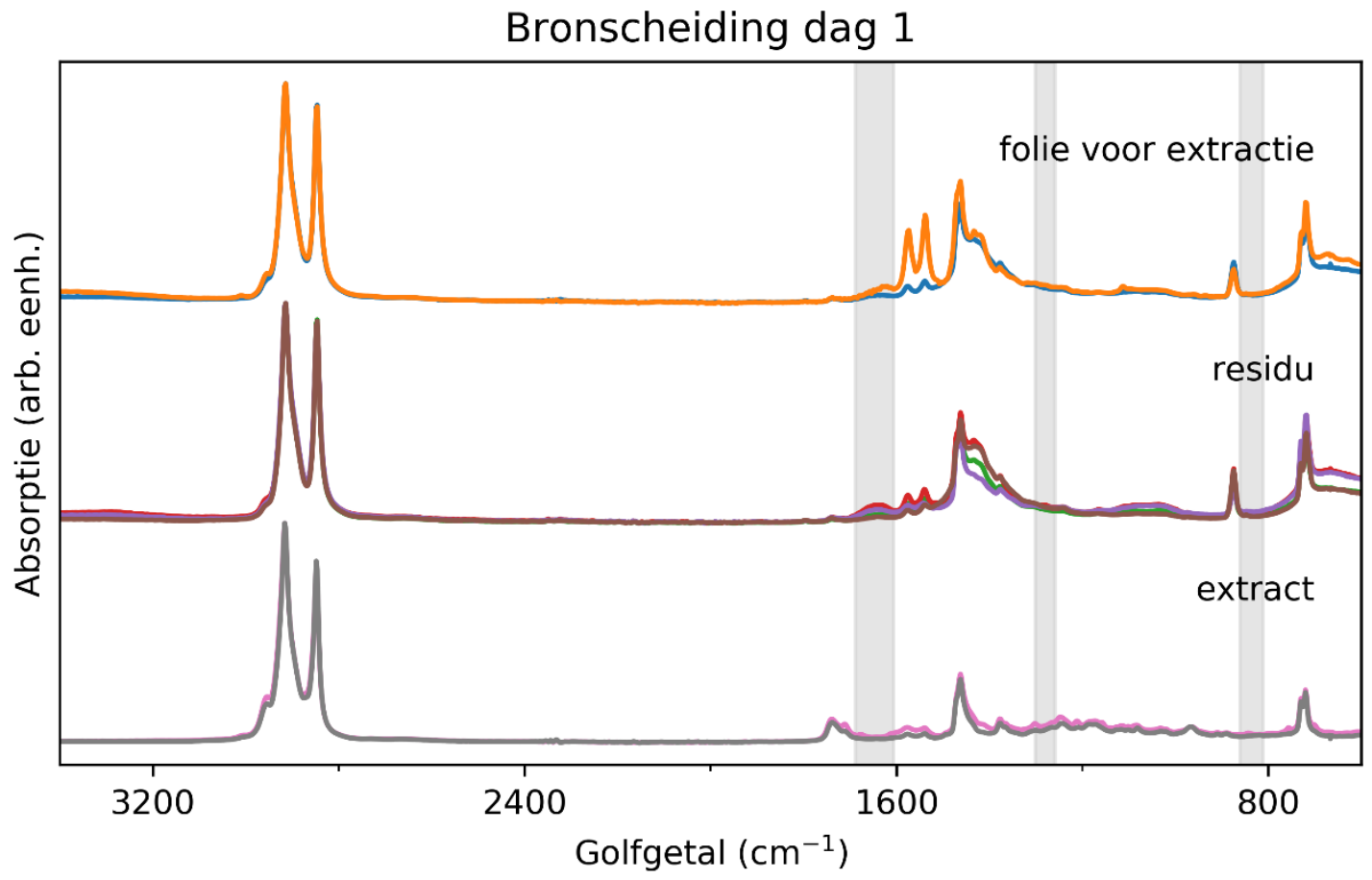

Figuur 22 Infrarood spectra van monster B1. De grijs gearceerde gebieden geven weer waar eventuele pieken kunnen worden toegeschreven aan de bedrukking op de Albert Heijn tassen 


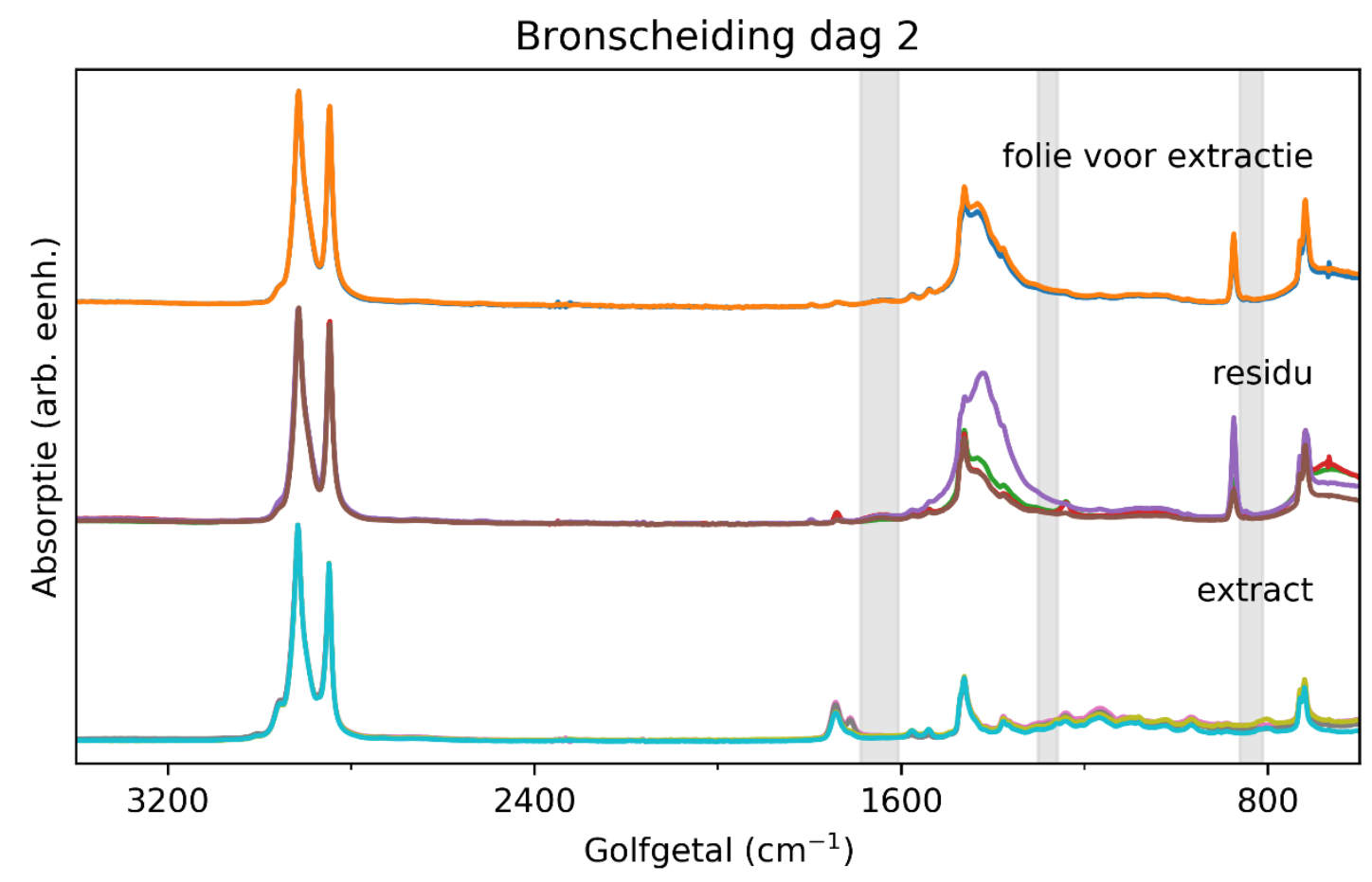

Figuur 23 Infrarood spectra van monster B2. De grijs gearceerde gebieden geven weer waar eventuele pieken kunnen worden toegeschreven aan de bedrukking op de Albert Heijn tassen

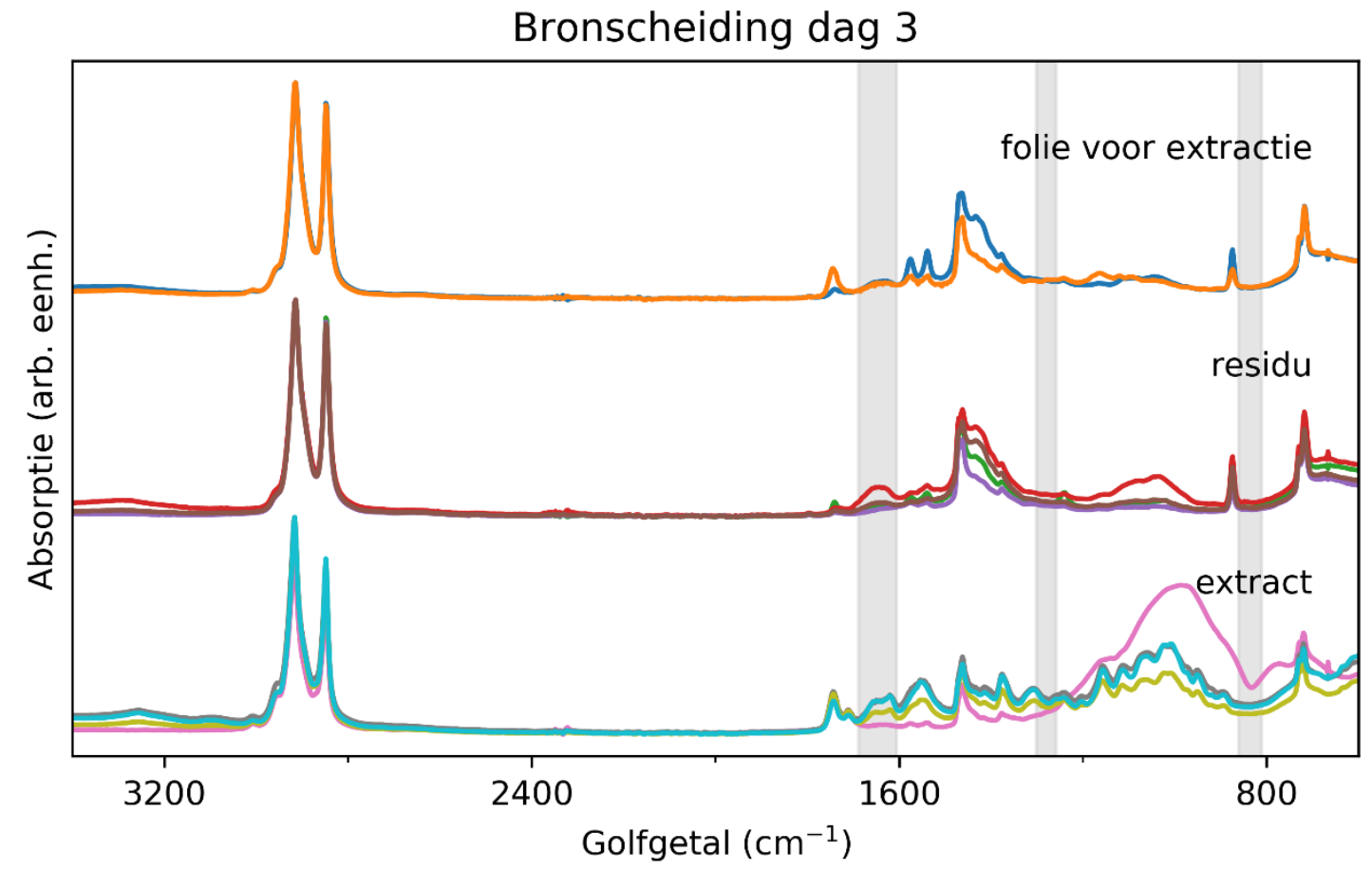

Figuur 24 Infrarood spectra van monster B3. De grijs gearceerde gebieden geven weer waar eventuele pieken kunnen worden toegeschreven aan de bedrukking op de Albert Heijn tassen 


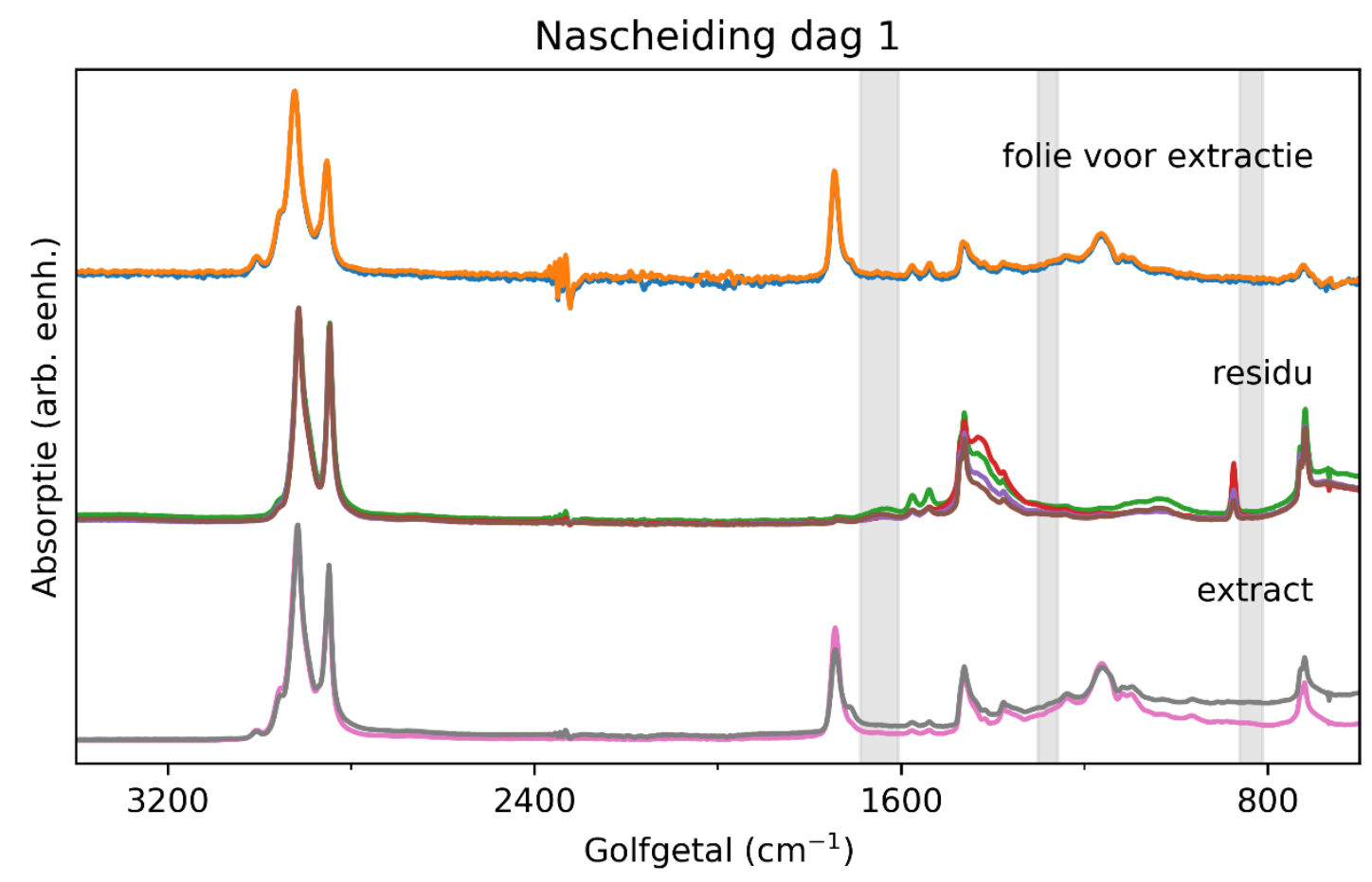

Figuur 25 Infrarood spectra van monster N1. De grijs gearceerde gebieden geven weer waar eventuele pieken kunnen worden toegeschreven aan de bedrukking op de Albert Heijn tassen

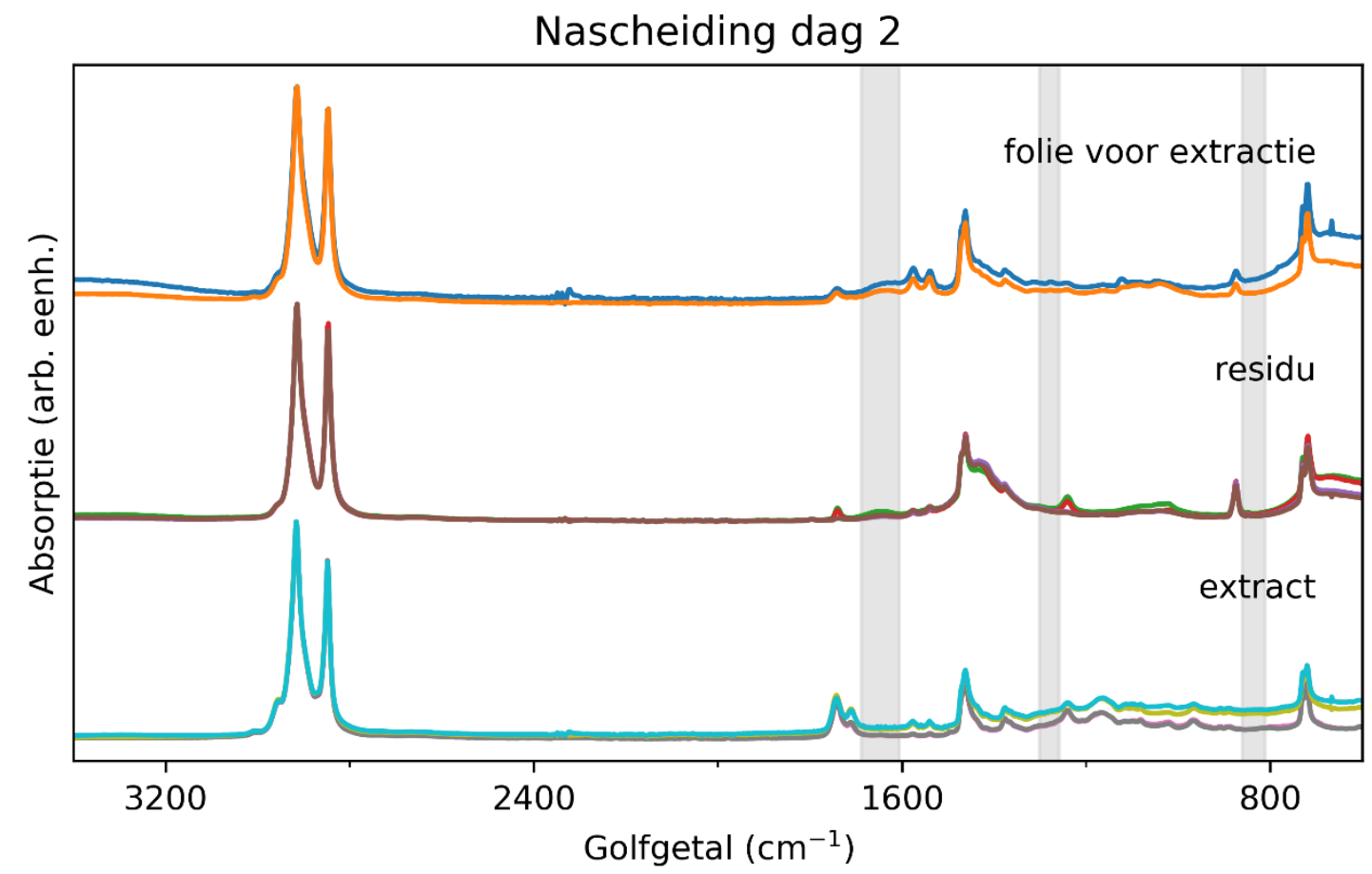

Figuur 26 Infrarood spectra van monster N2. De grijs gearceerde gebieden geven weer waar eventuele pieken kunnen worden toegeschreven aan de bedrukking op de Albert Heijn tassen 


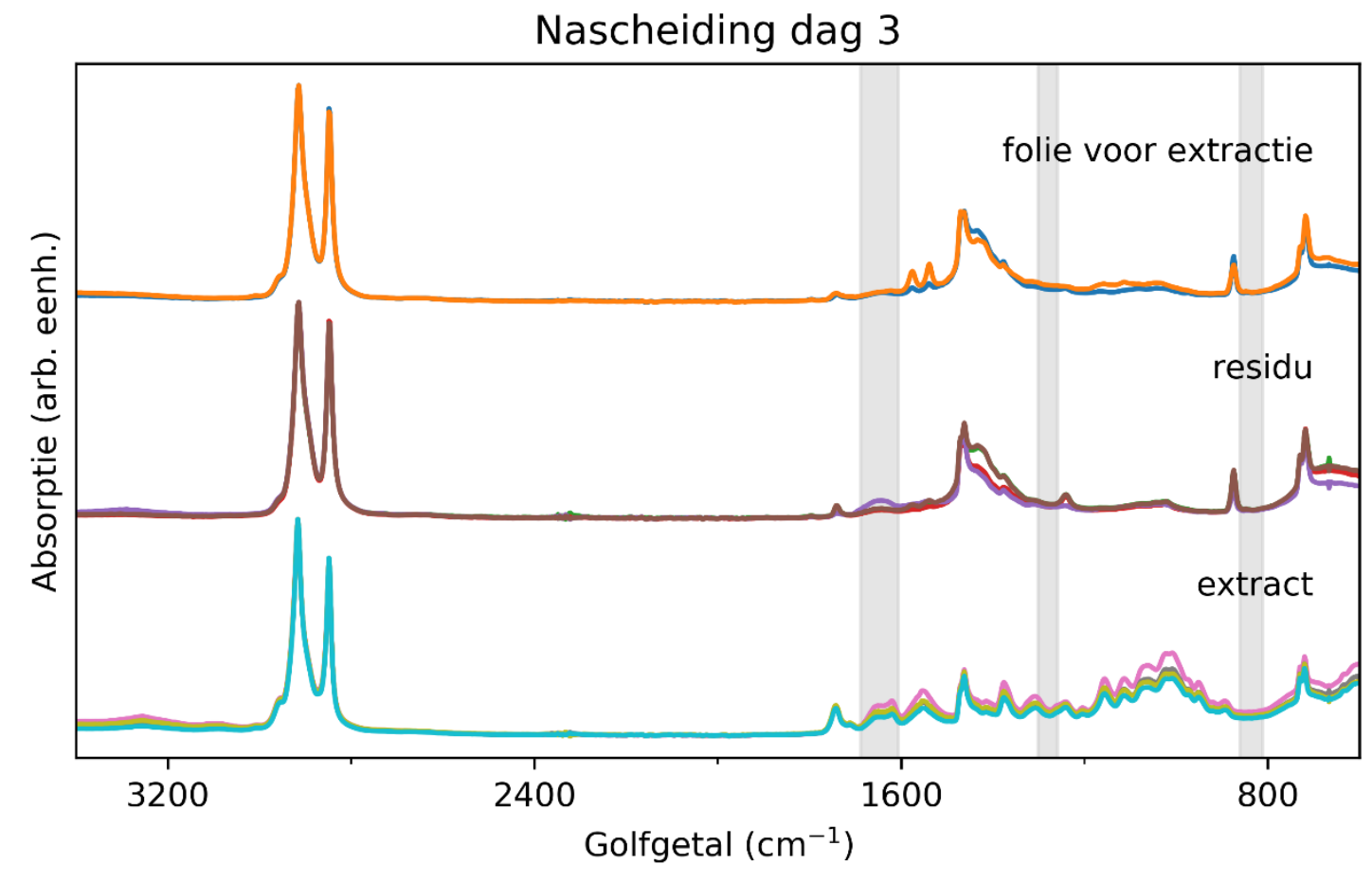

Figuur 27 Infrarood spectra van monster B3. De grijs gearceerde gebieden geven weer waar eventuele pieken kunnen worden toegeschreven aan de bedrukking op de Albert Heijn tassen 
Gaschromatogrammen van vluchtige stoffen

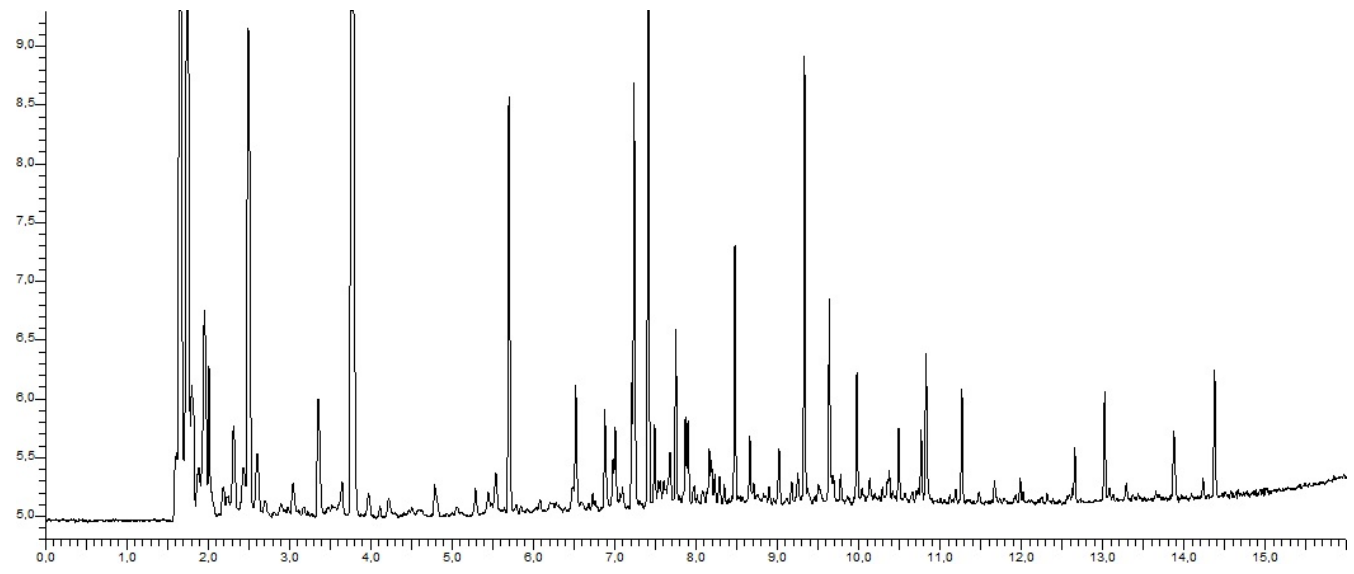

Figuur 28 Gaschromatogram van vluchtige stoffen in monster B1

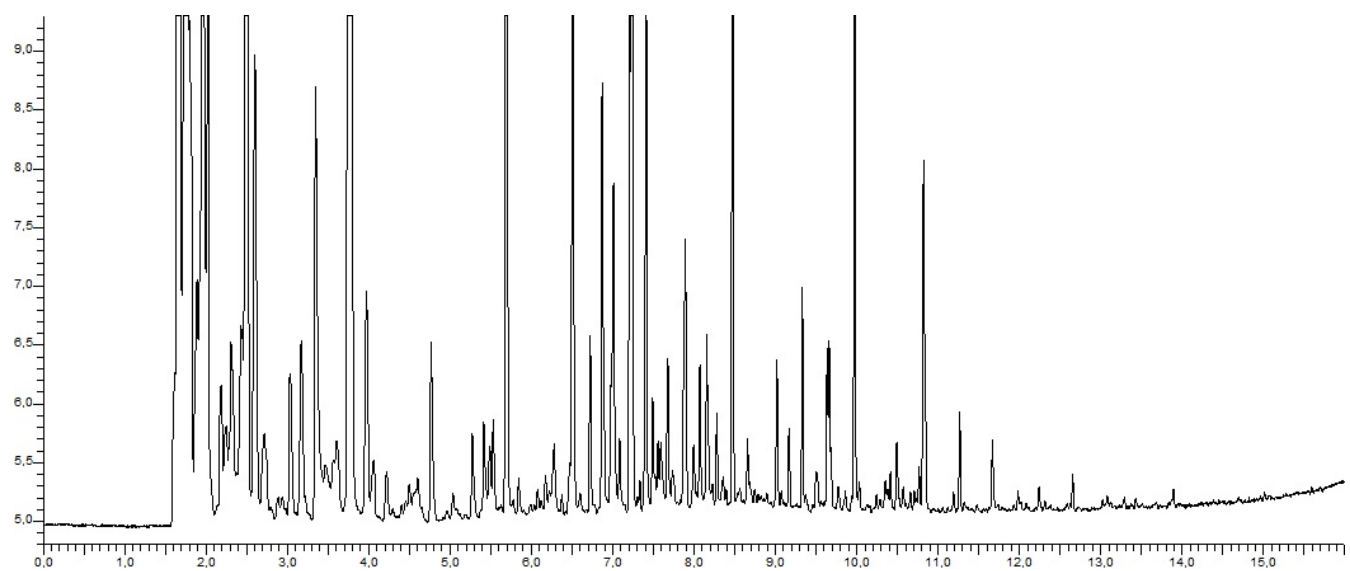

Figuur 29 Gaschromatogram van vluchtige stoffen in monster B2

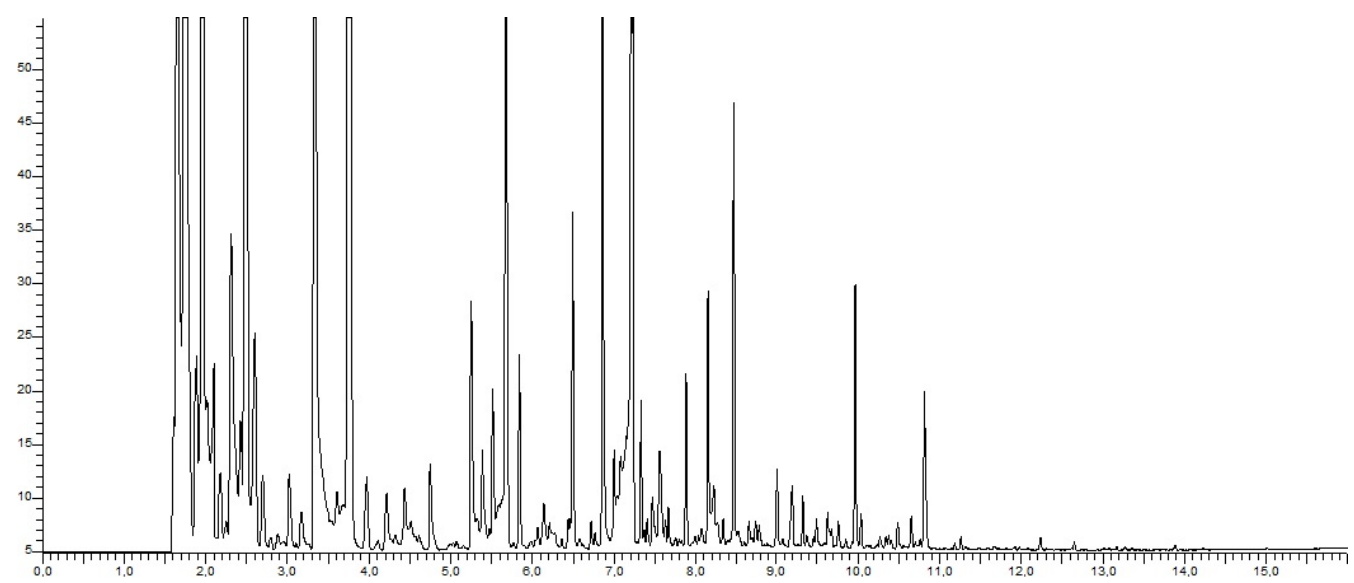

Figuur 30 Gaschromatogram van vluchtige stoffen in monster B3 


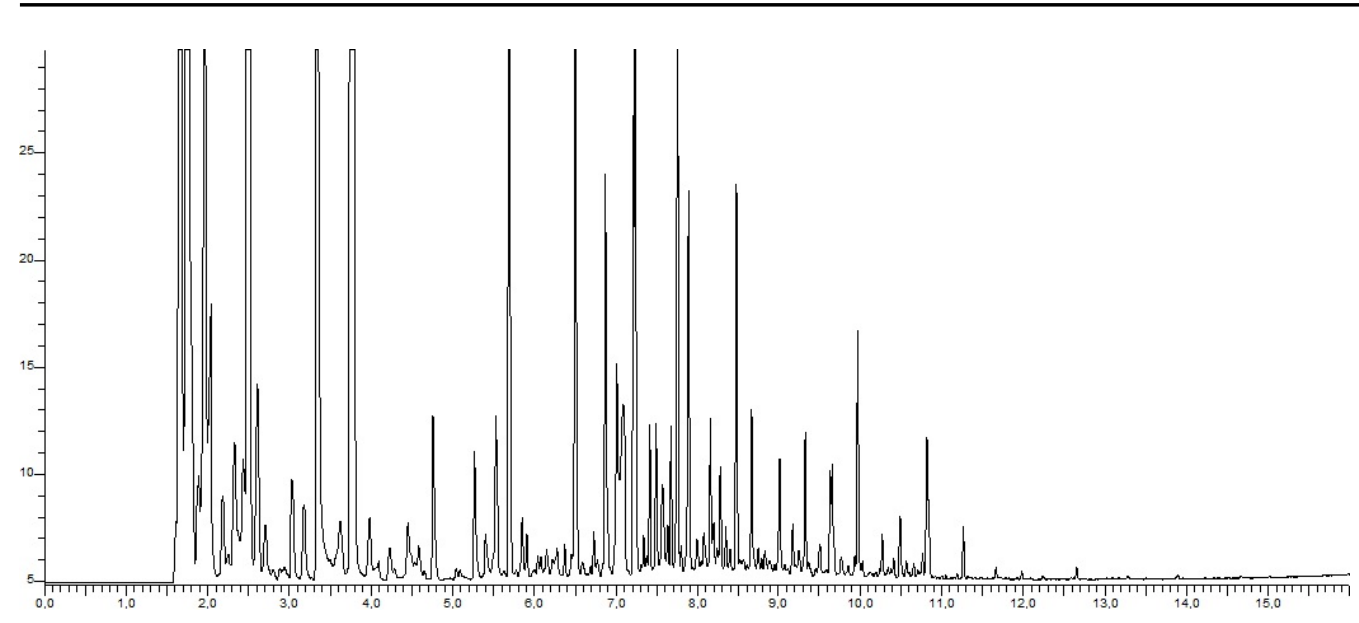

Figuur 31 Gaschromatogram van vluchtige stoffen in monster N1

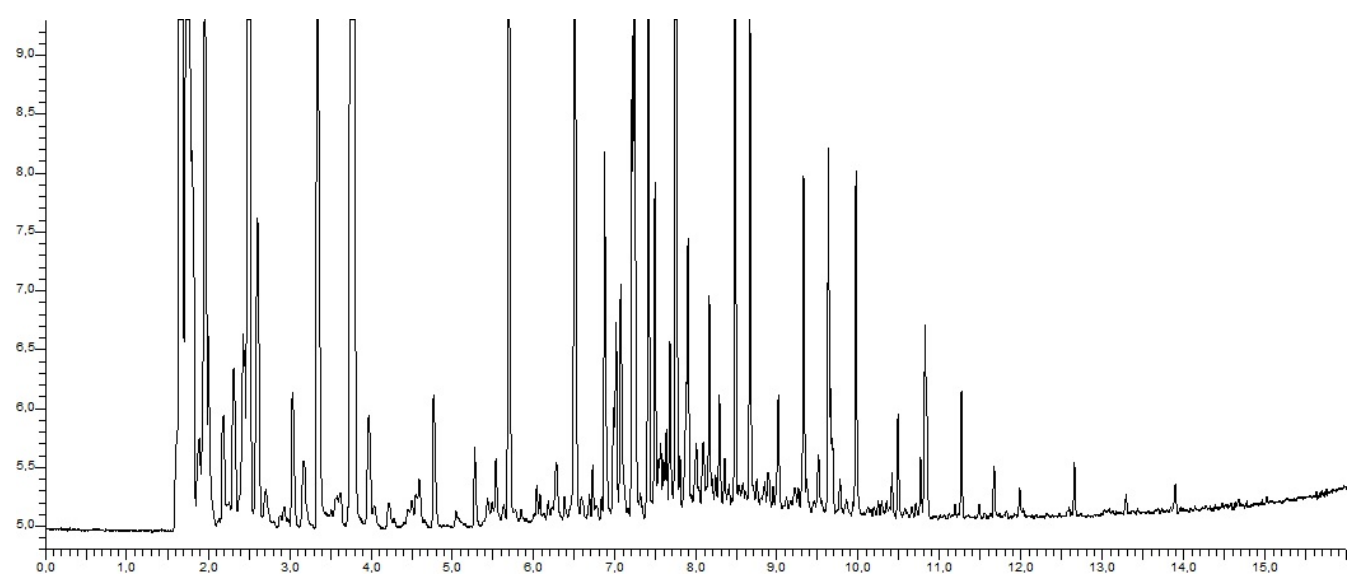

Figuur 32 Gaschromatogram van vluchtige stoffen in monster N2

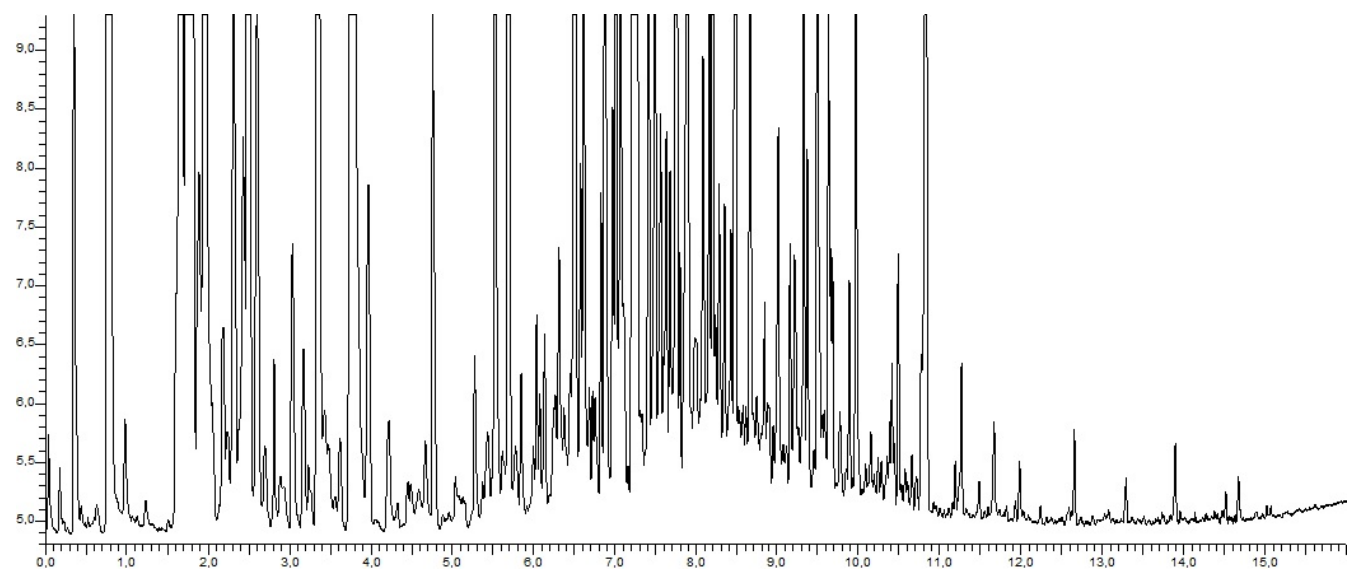

Figuur 33 Gaschromatogram van vluchtige stoffen in monster N3. Dit chromatogram moet buiten beschouwing gelaten worden in verband met analytische problemen 
Gaschromatogrammen van gemiddeld tot niet vluchtige stoffen

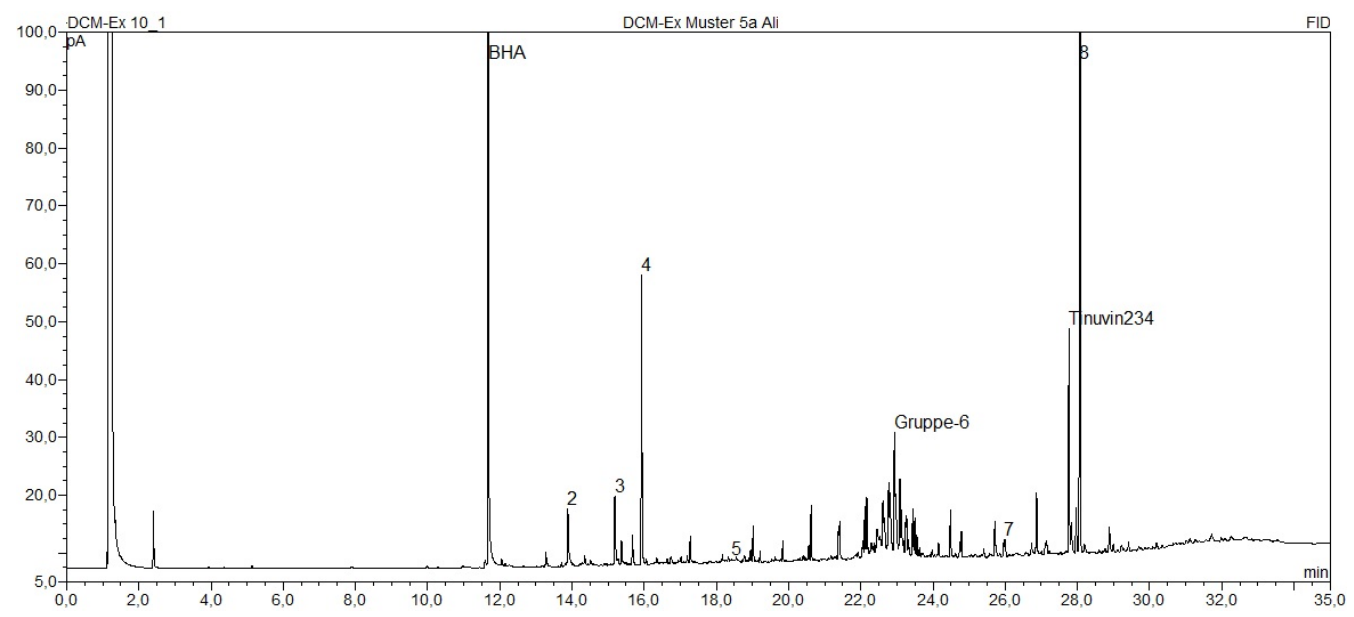

Figuur 34 Gaschromatogram van gemiddeld tot niet vluchtige stoffen in monster B1

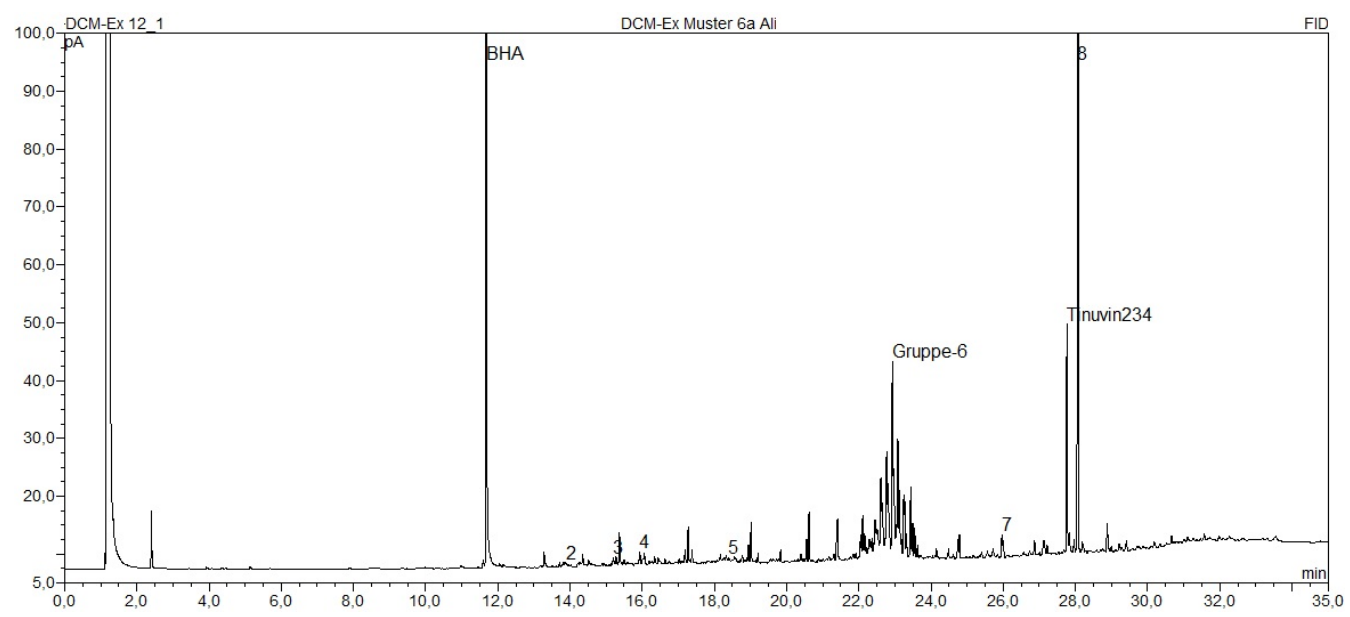

Figuur 35 Gaschromatogram van gemiddeld tot niet vluchtige stoffen in monster B2

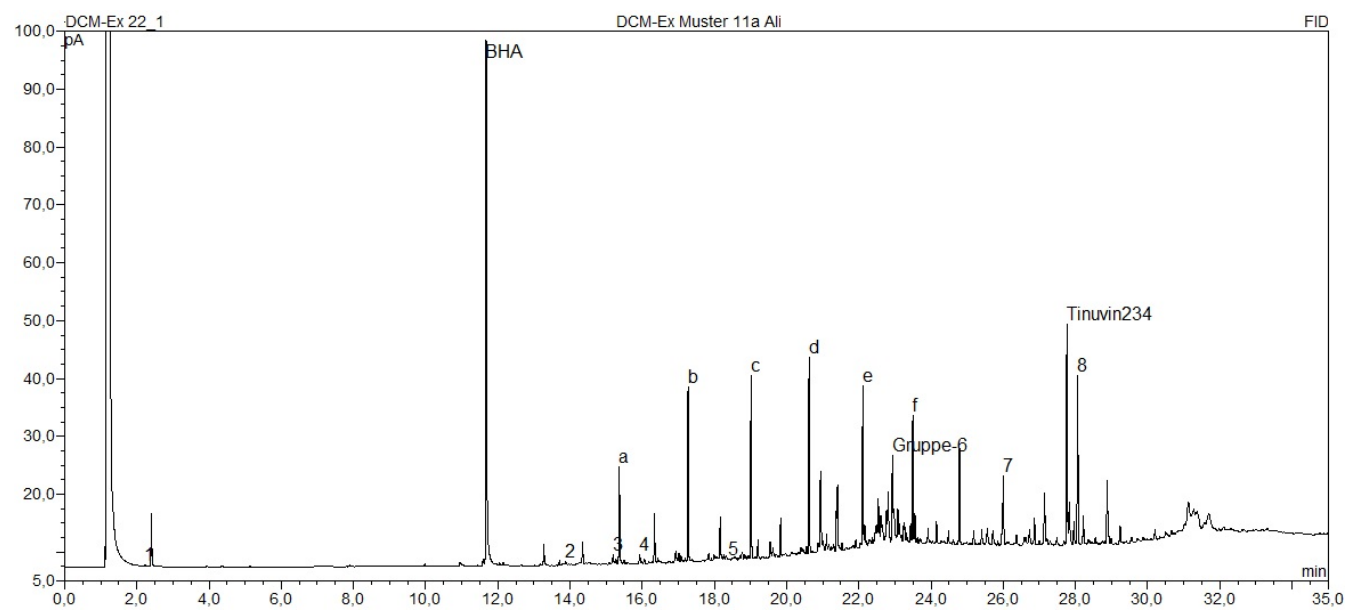

Figuur 36 Gaschromatogram van gemiddeld tot niet vluchtige stoffen in monster B3 


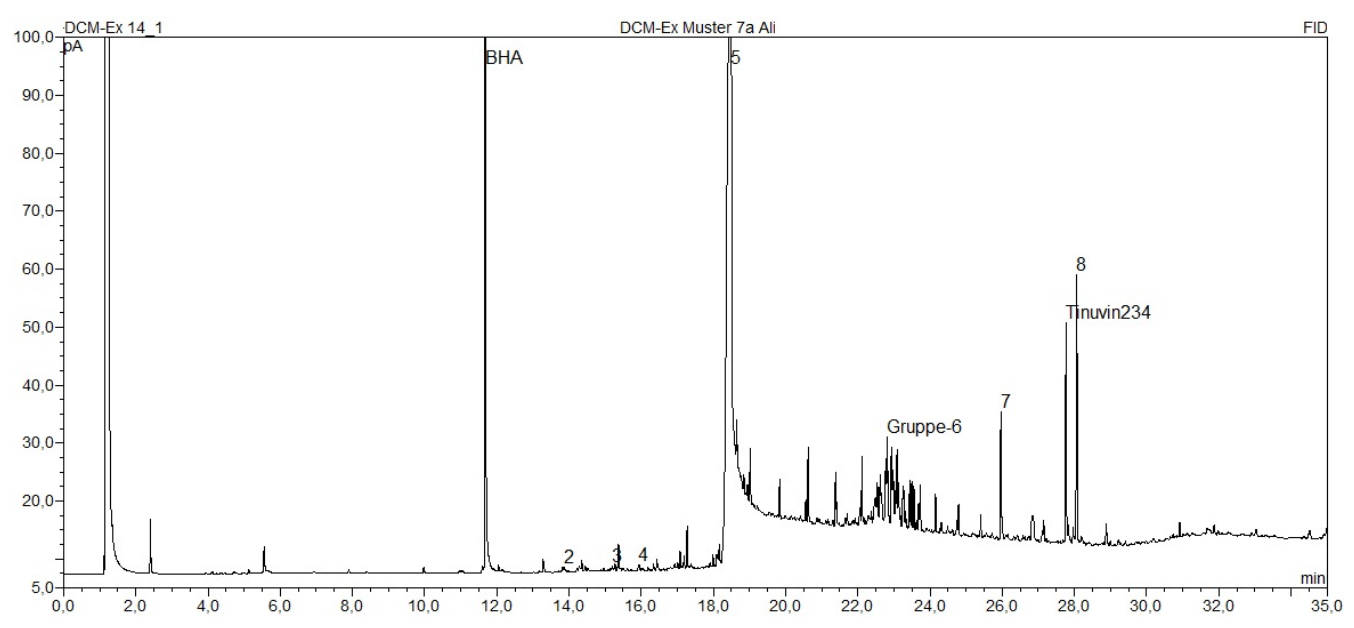

Figuur 37 Gaschromatogram van gemiddeld tot niet vluchtige stoffen in monster N1

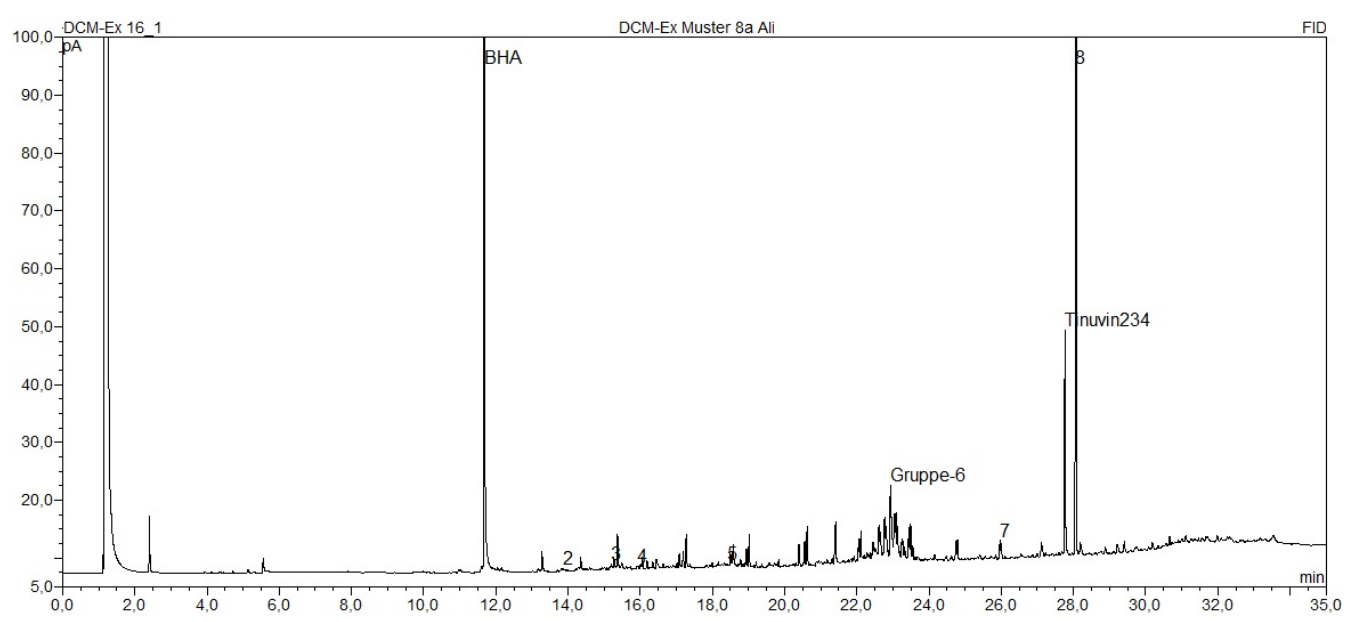

Figuur 38 Gaschromatogram van gemiddeld tot niet vluchtige stoffen in monster N2

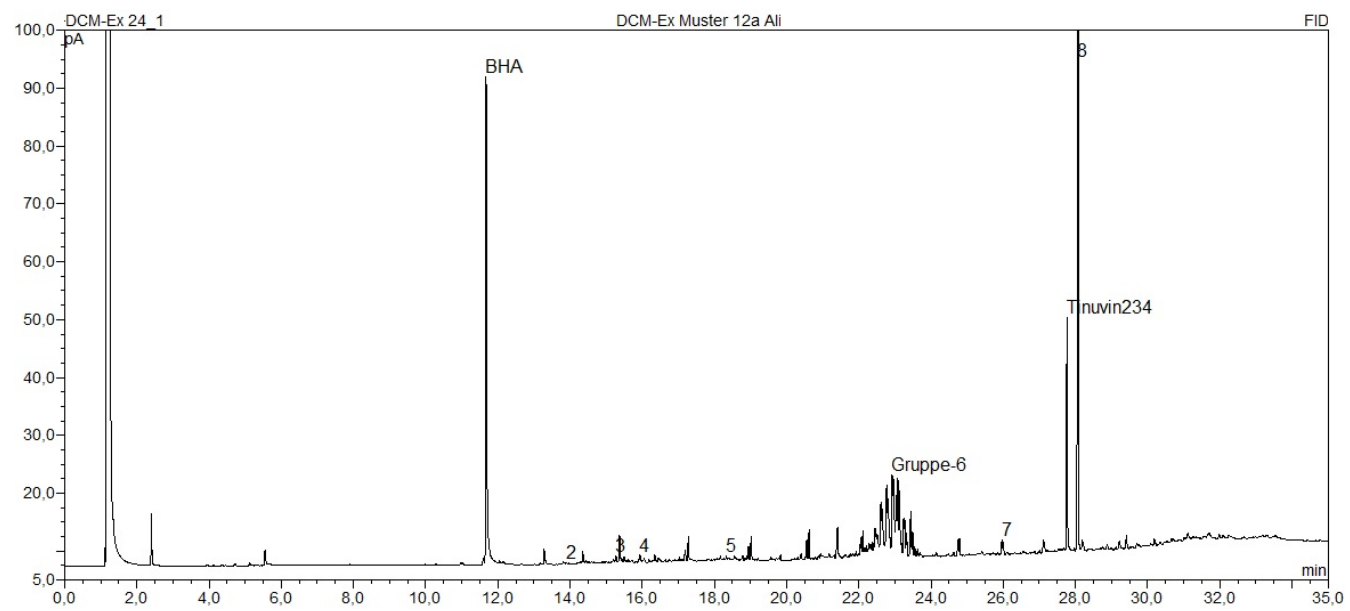

Figuur 39 Gaschromatogram van gemiddeld tot niet vluchtige stoffen in monster N3 
Tabel 13 Kwantificatie van de aangetroffen gemiddeld tot niet vluchtige stoffen in monsters (Albert Heijn tassen) genomen van zowel bronscheiding als nascheiding.

\begin{tabular}{|c|c|c|c|c|c|c|c|c|}
\hline \multirow[t]{2}{*}{ Piek } & \multirow[t]{2}{*}{$\begin{array}{l}\text { Retentie- } \\
\text { tijd (min) }\end{array}$} & \multirow[t]{2}{*}{ Identificatie } & \multicolumn{3}{|c|}{$\begin{array}{l}\text { Concentratie } \\
\text { Bronscheiding }\end{array}$} & \multicolumn{2}{|c|}{$\begin{array}{l}\text { Concentratie } \\
\text { Nascheiding }\end{array}$} & \multirow{2}{*}{$\begin{array}{l}(\mathrm{mg} / \mathrm{kg}) \\
\text { N3 }\end{array}$} \\
\hline & & & B1 & B2 & B3 & N1 & N2 & \\
\hline 1 & 2.4 & Niet geïdentificeerd & $<1$ & $<1$ & $<1$ & $<1$ & $<1$ & $<1$ \\
\hline 2 & 13.9 & Dioctylether & $70.0 \pm 7.4$ & $8.7 \pm 3.4$ & $10.4 \pm 2.0$ & $6.9 \pm 0.2$ & $2.7 \pm 0.9$ & $1.5 \pm 2.3$ \\
\hline 3 & 15.2 & Ethyhexyl salicylate & $79.3 \pm 15.4$ & $8.1 \pm 1.7$ & $13.8 \pm 2.6$ & $5.4 \pm 0.5$ & $8.0 \pm 1.7$ & $10.8 \pm 3.6$ \\
\hline a & 15.4 & Octadecaan & & & $56.6 \pm 24.2$ & & & \\
\hline 4 & 15.9 & Menthyl salicylate & $252 \pm 56$ & $15.7 \pm 3.8$ & $12.0 \pm 3.0$ & $6.7 \pm 1.3$ & $4.8 \pm 1.5$ & $10.0 \pm 2.1$ \\
\hline b & 17.4 & Eicosaan & & & $85.5 \pm 49.8$ & & & \\
\hline 5 & 18.5 & Oliezuur & $4.3 \pm 1.1$ & $7.2 \pm 1.9$ & $4.3 \pm 4.1$ & $2990 \pm 264$ & $3.2 \pm 2.2$ & $9.3 \pm 5.1$ \\
\hline c & 19.0 & Docosaan & & & $91.3 \pm 42.4$ & & & \\
\hline d & 20.6 & Tetracosaan & & & $100 \pm 51$ & & & \\
\hline e & 22.1 & Hexacosaan & & & $87.1 \pm 37.9$ & & & \\
\hline 6 & $22.4-22.7$ & $\begin{array}{l}\text { Di-isononyl-1,2- } \\
\text { cyclohexaandi- } \\
\text { carboxylaat (DINCH) }\end{array}$ & $1670 \pm 784$ & $921 \pm 433$ & $671 \pm 340$ & $1030 \pm 30$ & $641 \pm 53$ & $971 \pm 25$ \\
\hline$f$ & 23.5 & Octacosaan & & & $68.1 \pm 34.2$ & & & \\
\hline 7 & 26.0 & $\begin{array}{l}\text { Bis(2-ethylhexyl)ftalaat } \\
\text { (DEHP) }\end{array}$ & $17.3 \pm 3.0$ & $14.8 \pm 4.9$ & $41.9 \pm 27.7$ & $111 \pm 1$ & $\begin{array}{l}14.6 \pm \\
5.6\end{array}$ & $13.5 \pm 0.4$ \\
\hline 8 & 28.1 & Geoxideerd Irgafos 168 & $562 \pm 30$ & $557 \pm 36$ & $347 \pm 232$ & $235 \pm 19$ & $479 \pm 15$ & $675 \pm 20$ \\
\hline
\end{tabular}




\section{Bijlage 2 Additionele data taak $1 \mathrm{~b}$}

Gaschromatogrammen van vluchtige stoffen

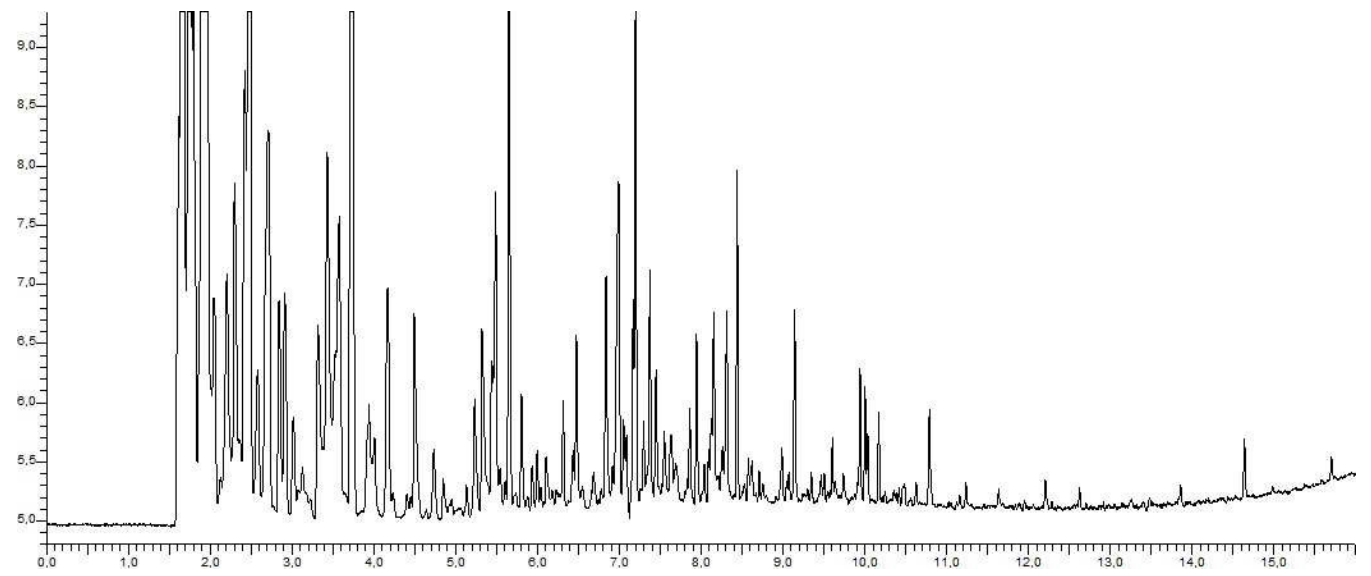

Figuur 40 Gaschromatogram van vluchtige stoffen in submonster B1-kz

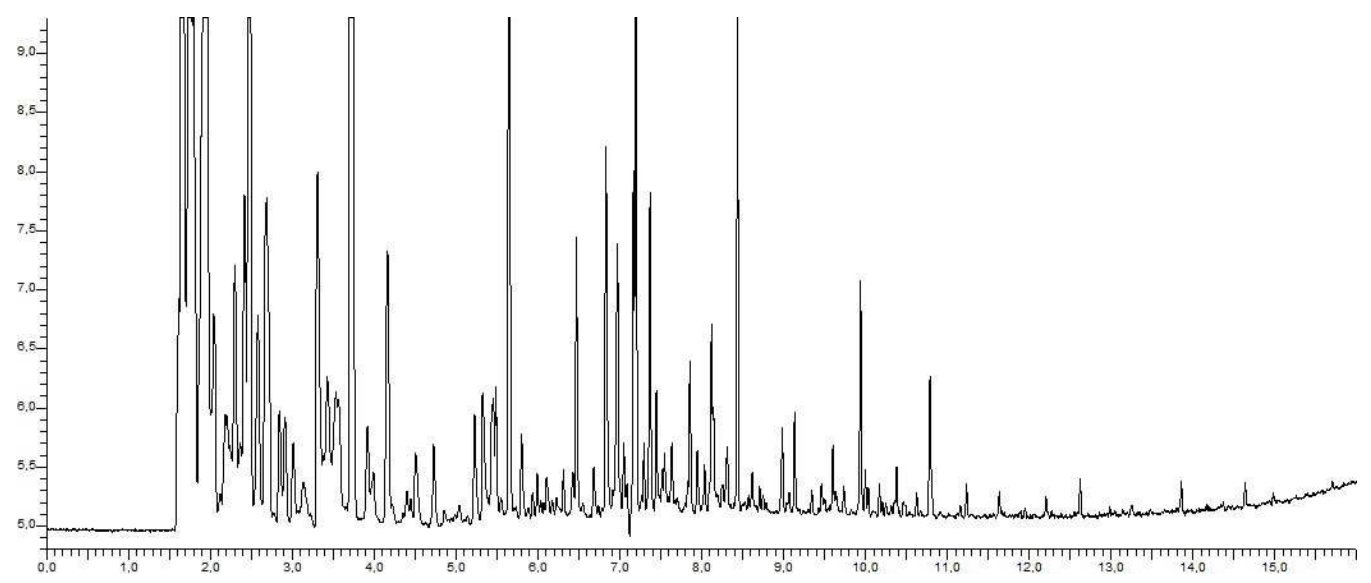

Figuur 41 Gaschromatogram van vluchtige stoffen in submonster B2-kz

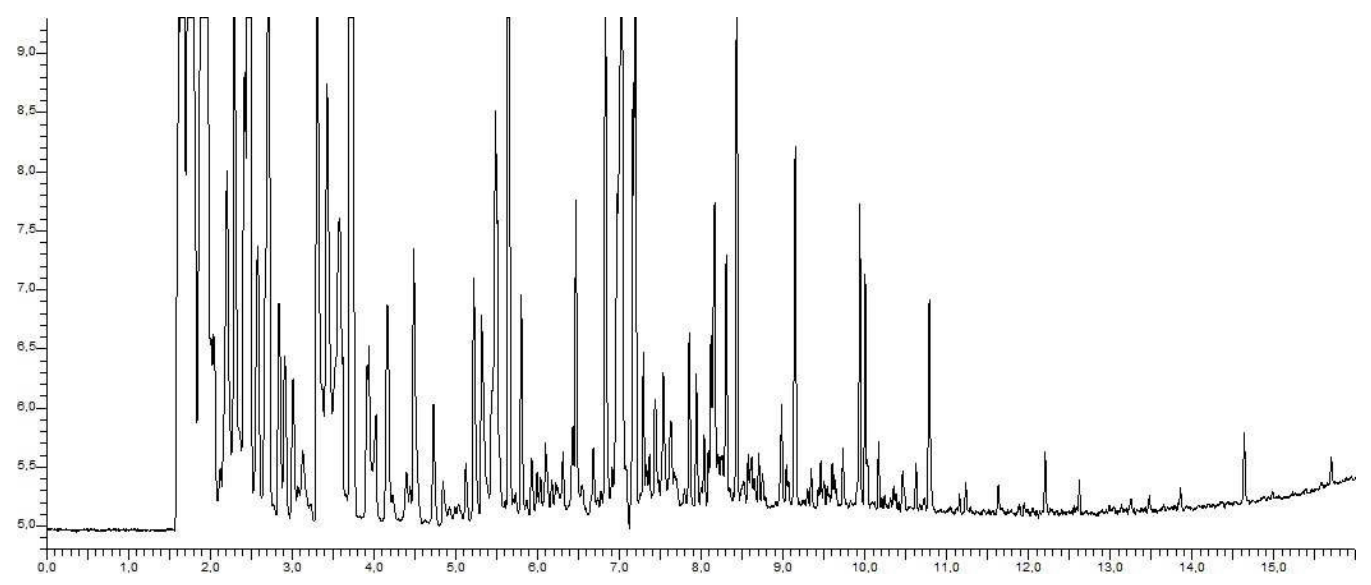

Figuur 42 Gaschromatogram van vluchtige stoffen in submonster B3-kz 


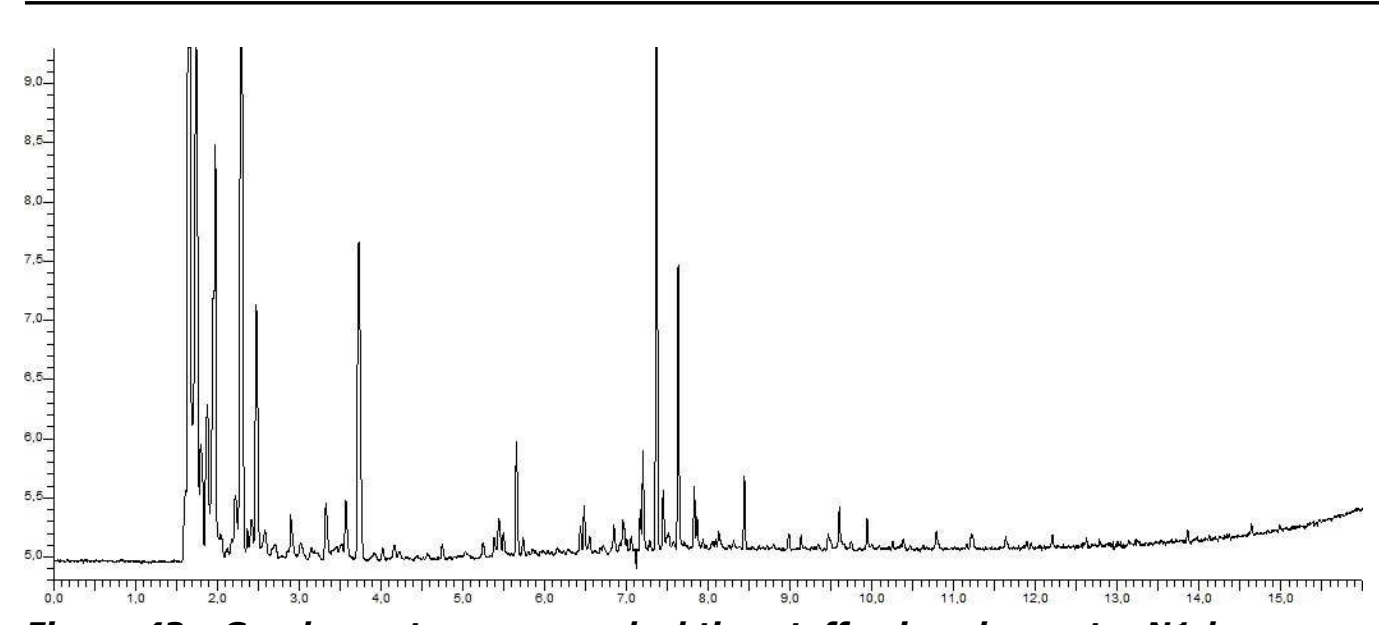

Figuur 43 Gaschromatogram van vluchtige stoffen in submonster N1-kz

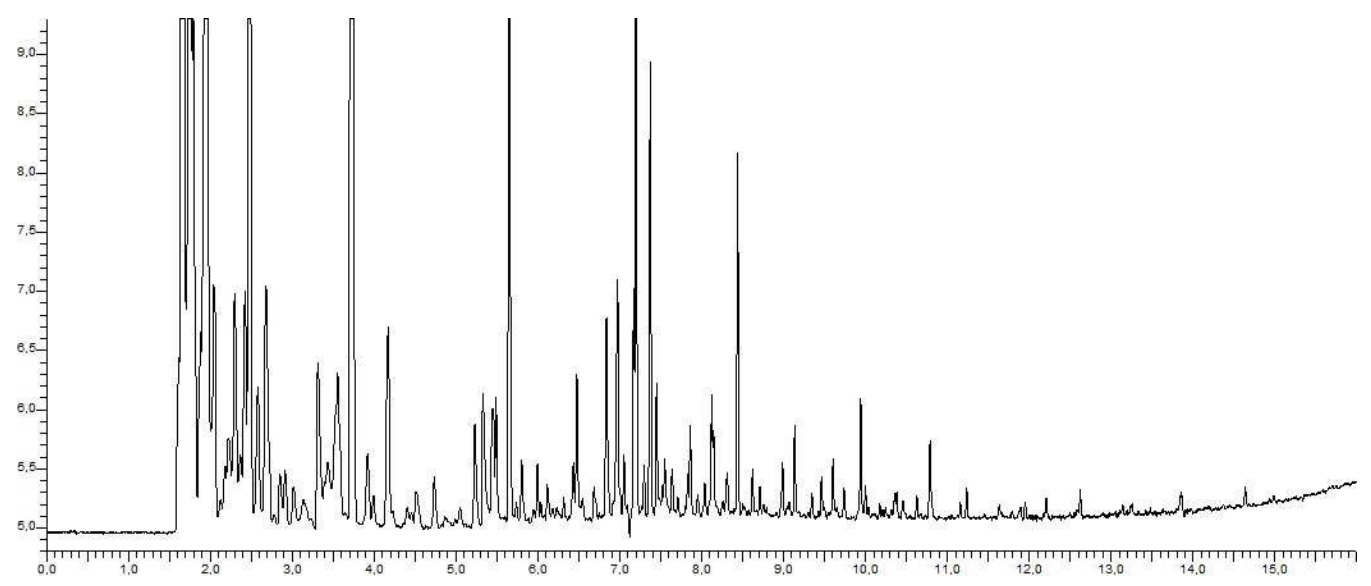

Figuur 44 Gaschromatogram van vluchtige stoffen in submonster N2-kz

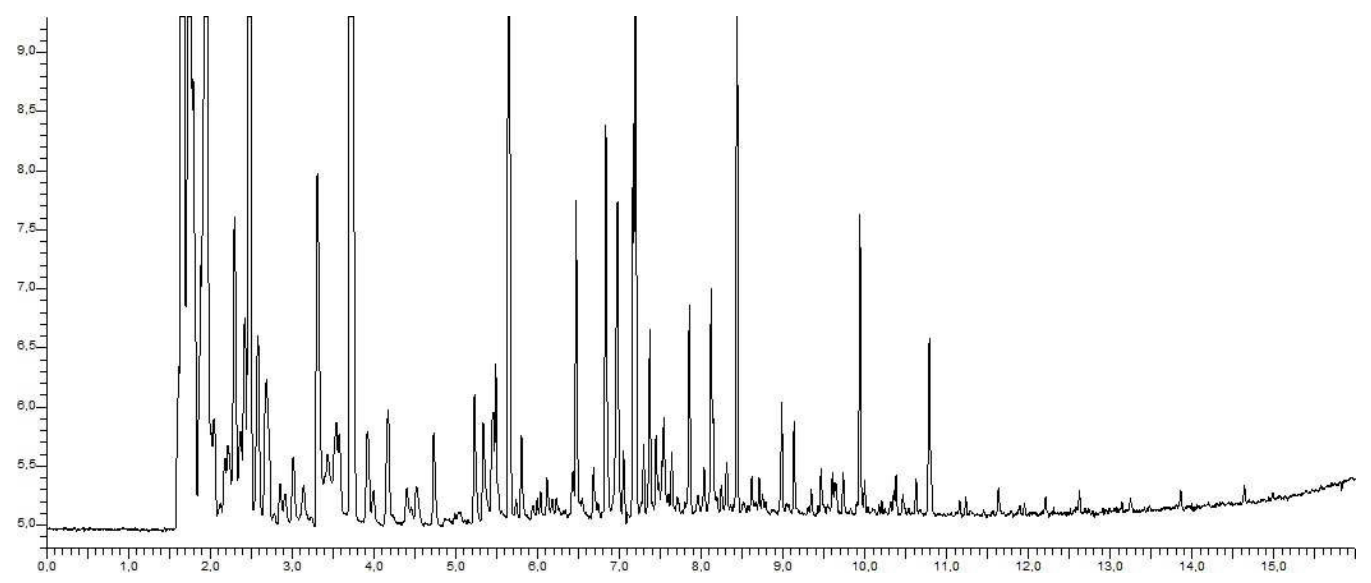

Figuur 45 Gaschromatogram van vluchtige stoffen in submonster N3-kz 
Gaschromatogrammen van gemiddeld tot niet vluchtige stoffen

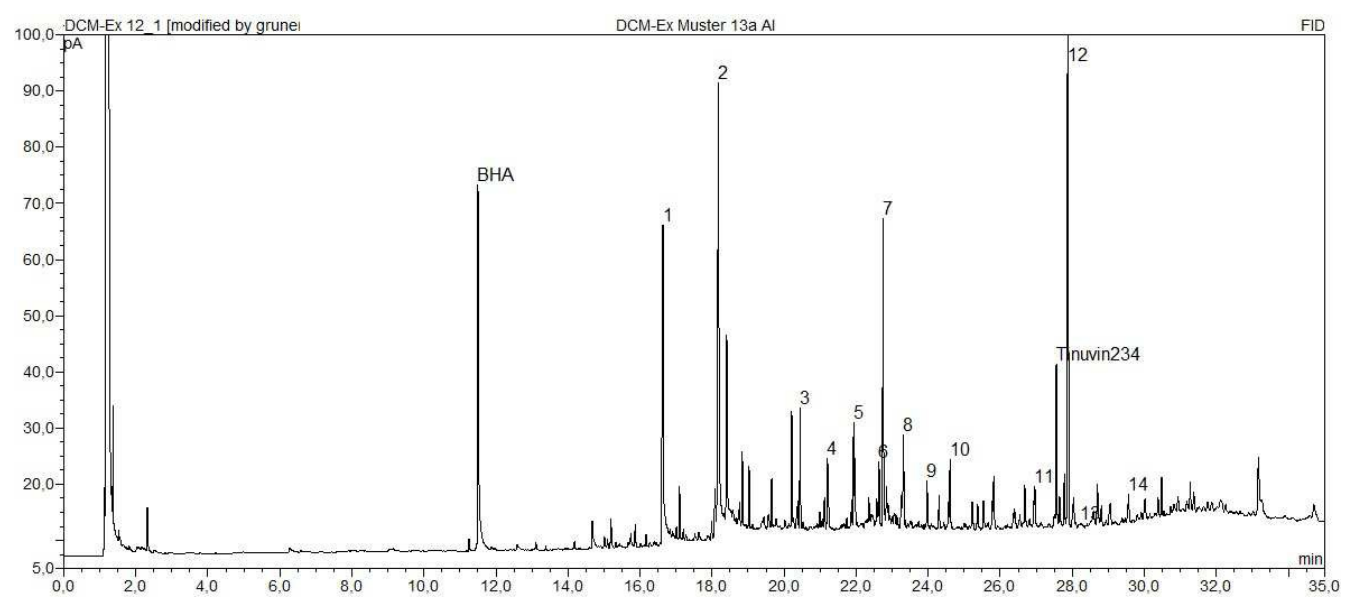

Figuur 46 Gaschromatogram van gemiddeld tot niet vluchtige stoffen in submonster B1-kz

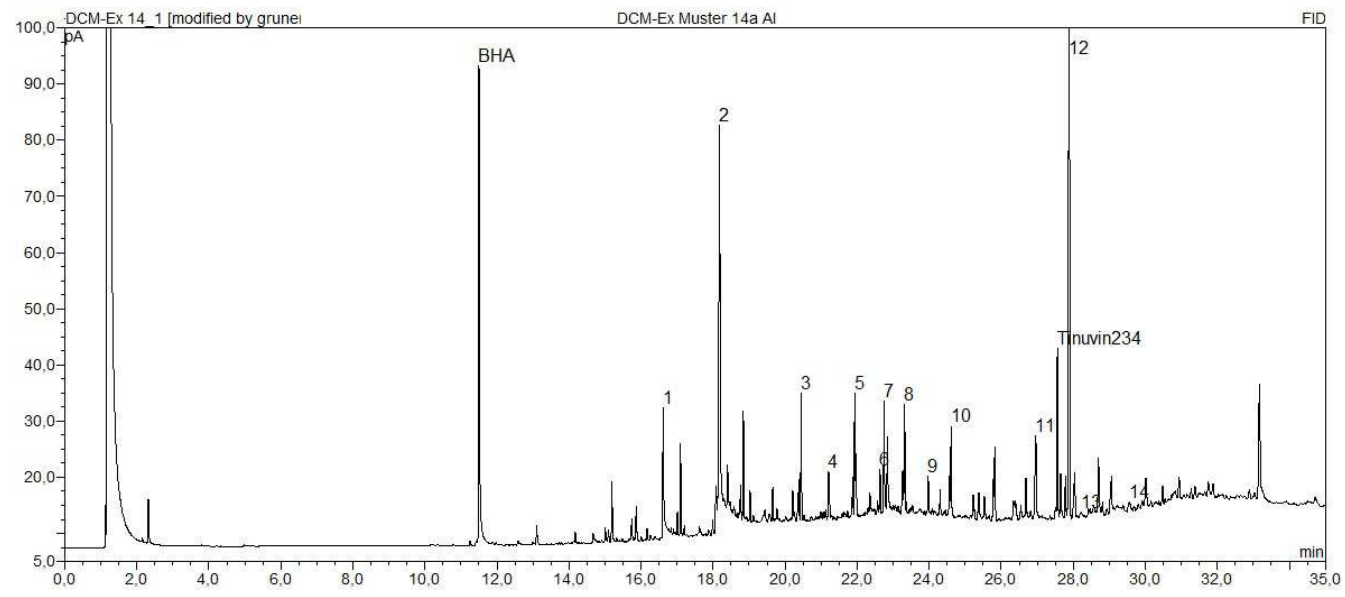

Figuur 47 Gaschromatogram van gemiddeld tot niet vluchtige stoffen in submonster B2-kz

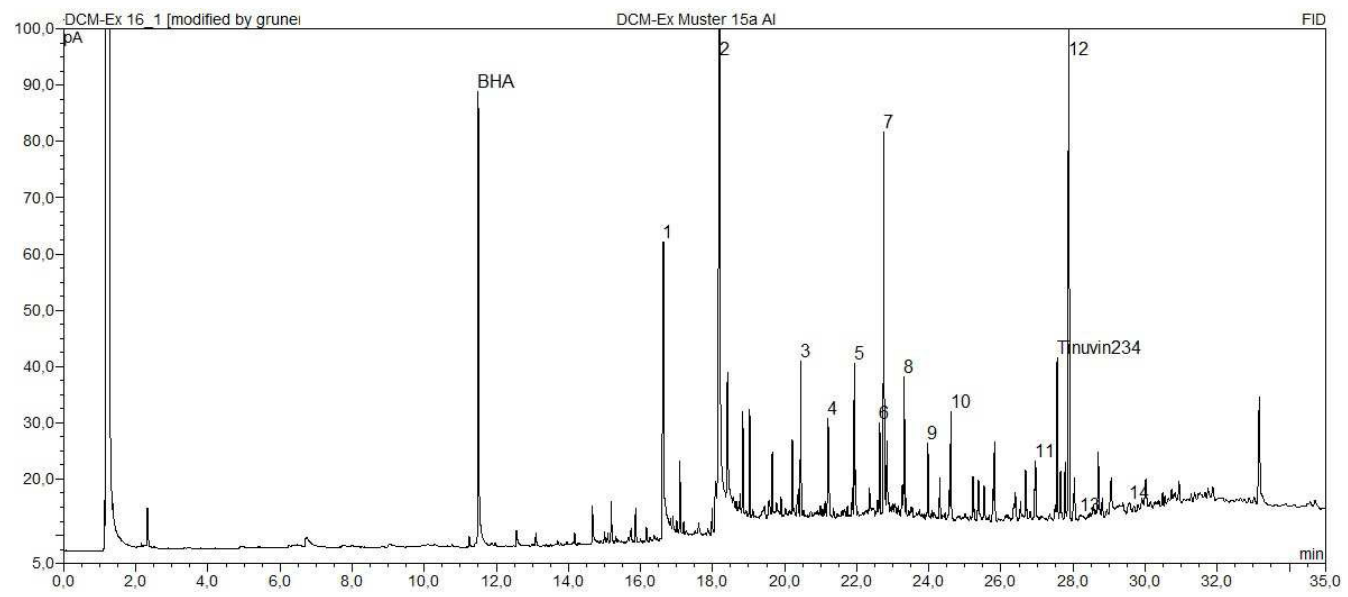

Figuur 48 Gaschromatogram van gemiddeld tot niet vluchtige stoffen in submonster B3-kz 


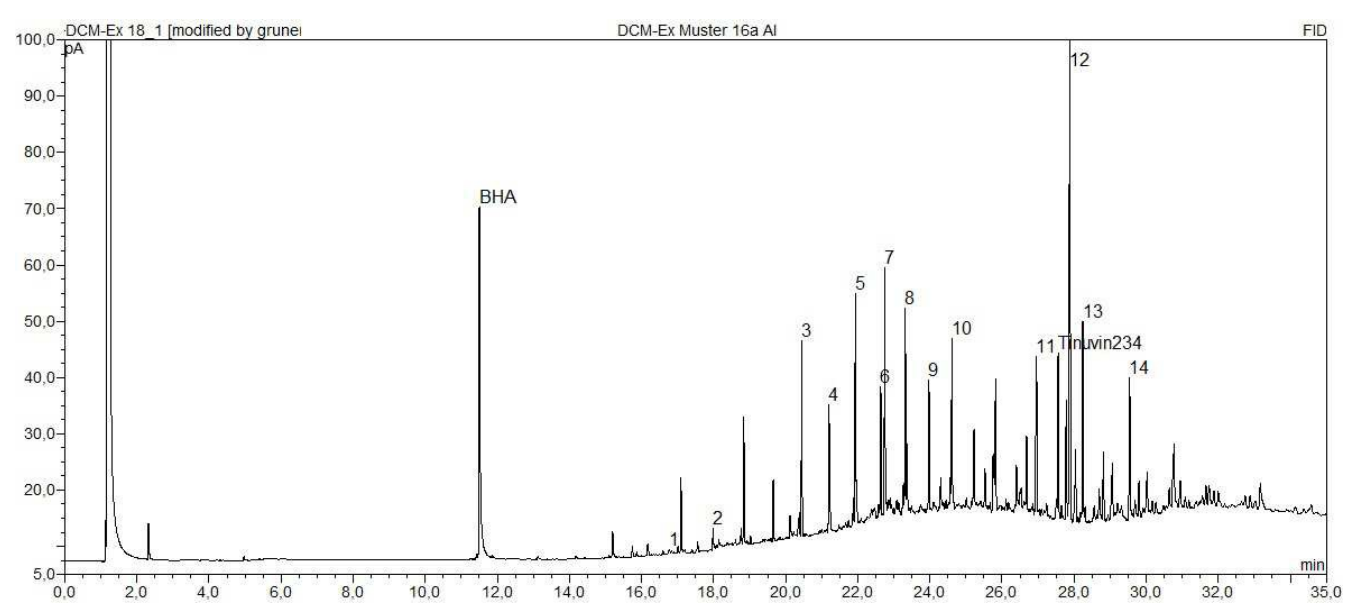

Figuur 49 Gaschromatogram van gemiddeld tot niet vluchtige stoffen in submonster N1-kz

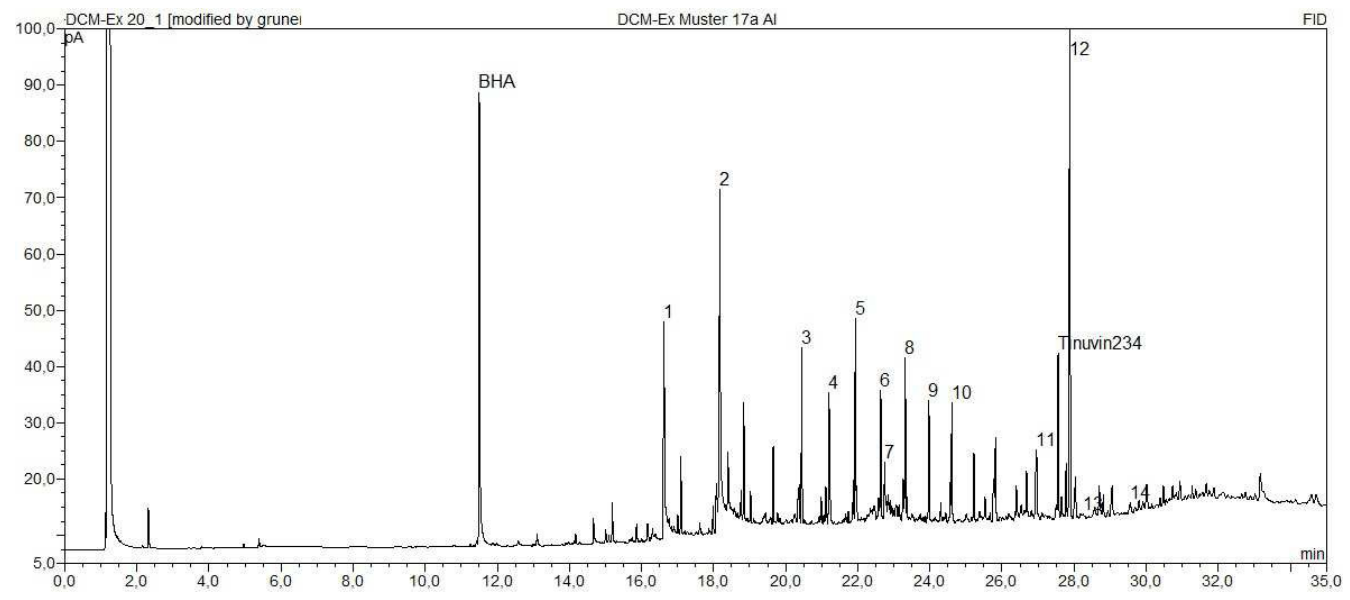

Figuur 50 Gaschromatogram van gemiddeld tot niet vluchtige stoffen in submonster N2-kz

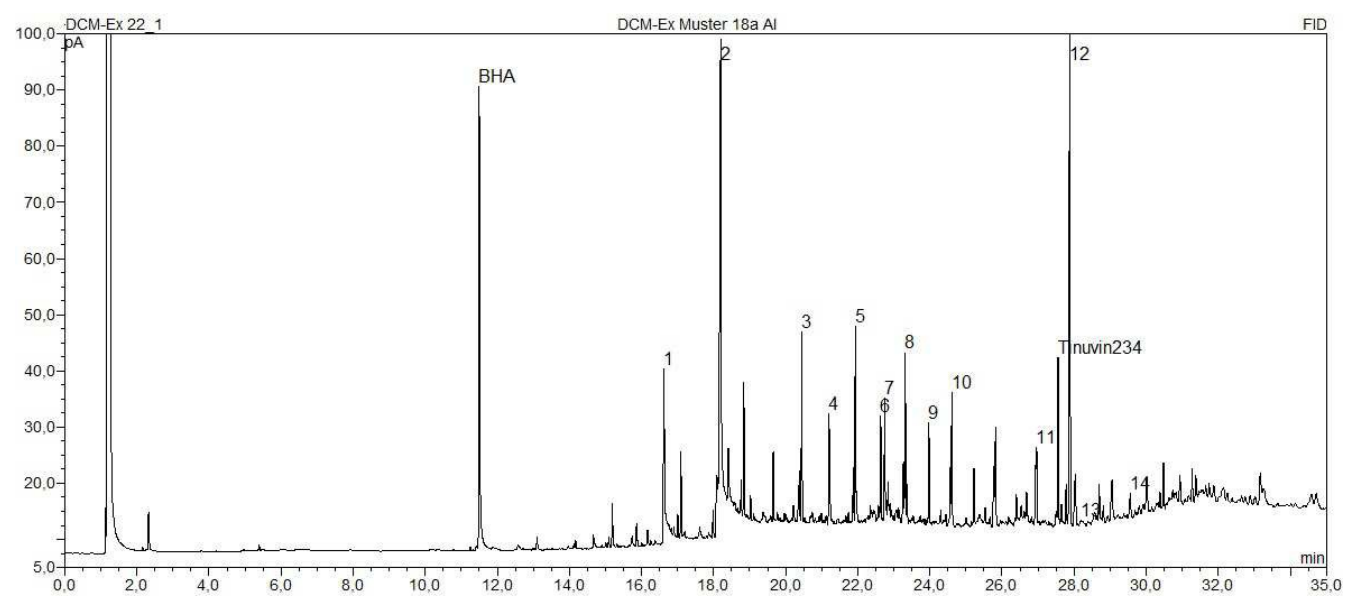

Figuur 51 Gaschromatogram van gemiddeld tot niet vluchtige stoffen in submonster N3-kz 
Tabel 14 Kwantificatie van de aangetroffen gemiddeld tot niet vluchtige stoffen in de deelmonsters genomen van zowel bronscheiding als nascheiding.

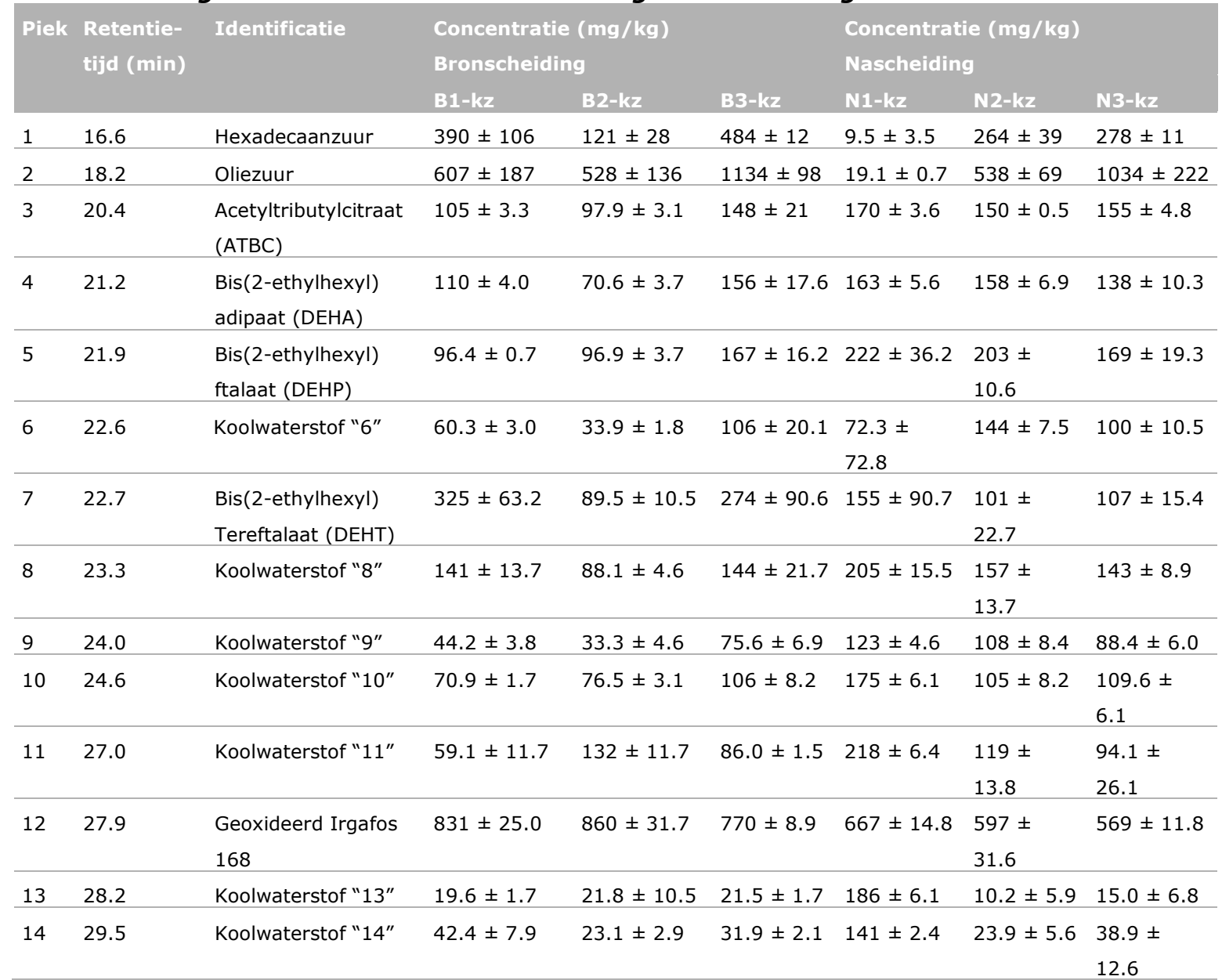
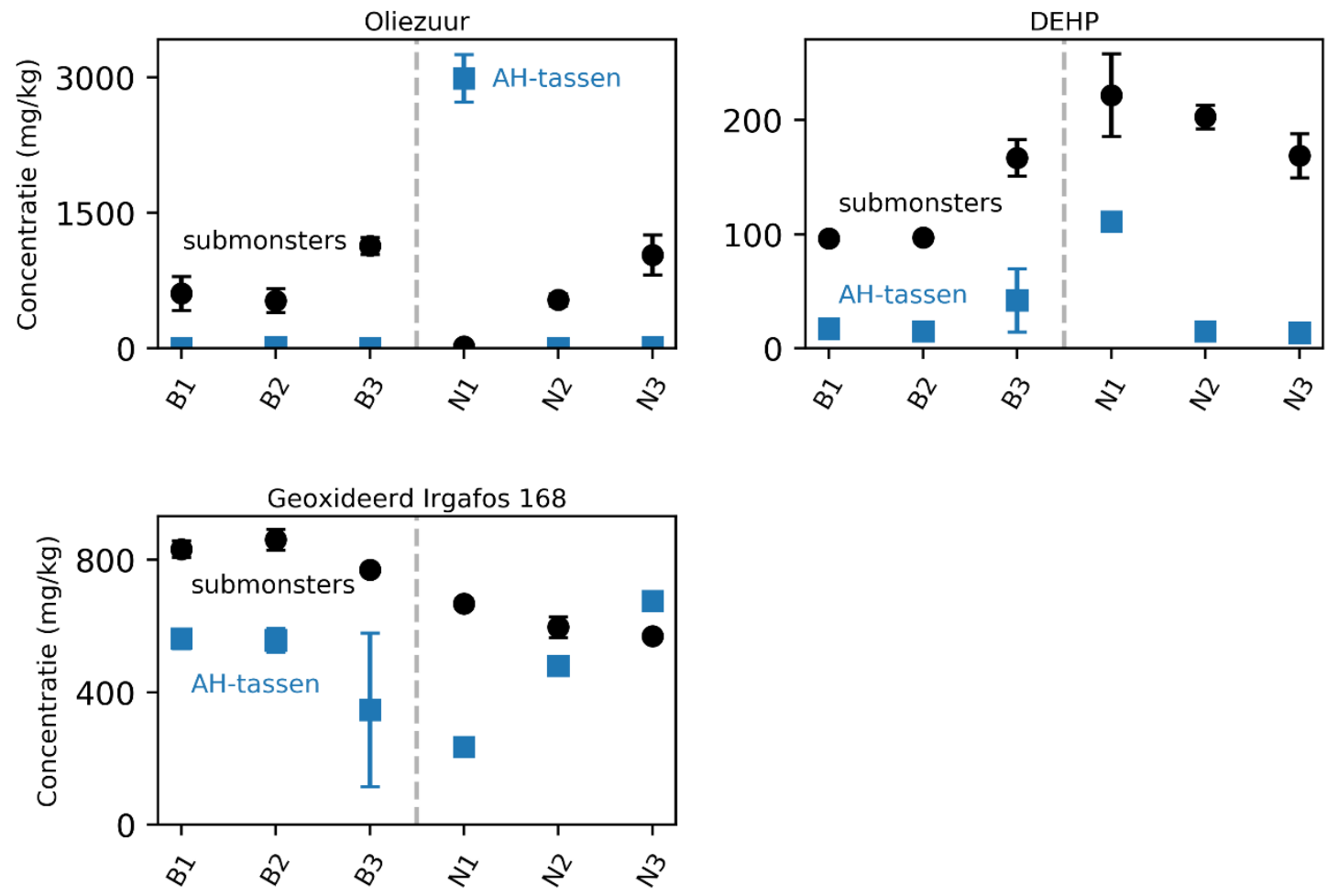

Figuur 52 Vergelijking van de concentraties van aangetroffen stoffen in zowel de Albert Heijn tassen alsmede de submonsters per monster. De data van de Albert Heijn tassen is weergegeven in blauwe vierkantjes, de data van de submonsters in zwarte rondjes 
Geurpanelanalyse

Tabel 15 Resultaten van de ANOVA test (gemiddelde scores) en Duncan test.

Verschillende letters voor een bepaalde geureigenschap betekent een significant verschil, $a \leq 0.05$ ).

\begin{tabular}{lllllll} 
Geureigenschap & \multicolumn{5}{l}{ Bronscheiding } & \multicolumn{3}{l}{ Nascheiding } \\
& B1-kz & B2-kz & B3-kz & N1-kz & N2-kz & N3-kz \\
Zeepachtig, wasmiddelachtig & $46(\mathrm{~A})$ & $34(\mathrm{~A})$ & $32(\mathrm{~A})$ & $38(\mathrm{~A})$ & $39(\mathrm{~A})$ & $28(\mathrm{~A})$ \\
\hline Kaasachtig, zweetachtig & $23(\mathrm{~A})$ & $15(\mathrm{~A})$ & $33(\mathrm{~A})$ & $22(\mathrm{~A})$ & $29(\mathrm{~A})$ & $24(\mathrm{~A})$ \\
\hline Aards, muf & $34(\mathrm{AB})$ & $11(\mathrm{~B})$ & $14(\mathrm{~B})$ & $32(\mathrm{AB})$ & $43(\mathrm{~A})$ & $33(\mathrm{AB})$ \\
\hline Ranzig nootachtig & $49(\mathrm{~B})$ & $77(\mathrm{~A})$ & $77(\mathrm{~A})$ & $22(\mathrm{C})$ & $54(\mathrm{AB})$ & $51(\mathrm{AB})$ \\
\hline Metaalachtig & $28(\mathrm{~A})$ & $14(\mathrm{~A})$ & $13(\mathrm{~A})$ & $22(\mathrm{~A})$ & $22(\mathrm{~A})$ & $27(\mathrm{~A})$ \\
\hline
\end{tabular}




\section{Bijlage 3 Additionele data taak 2}

Gaschromatogrammen van vluchtige stoffen

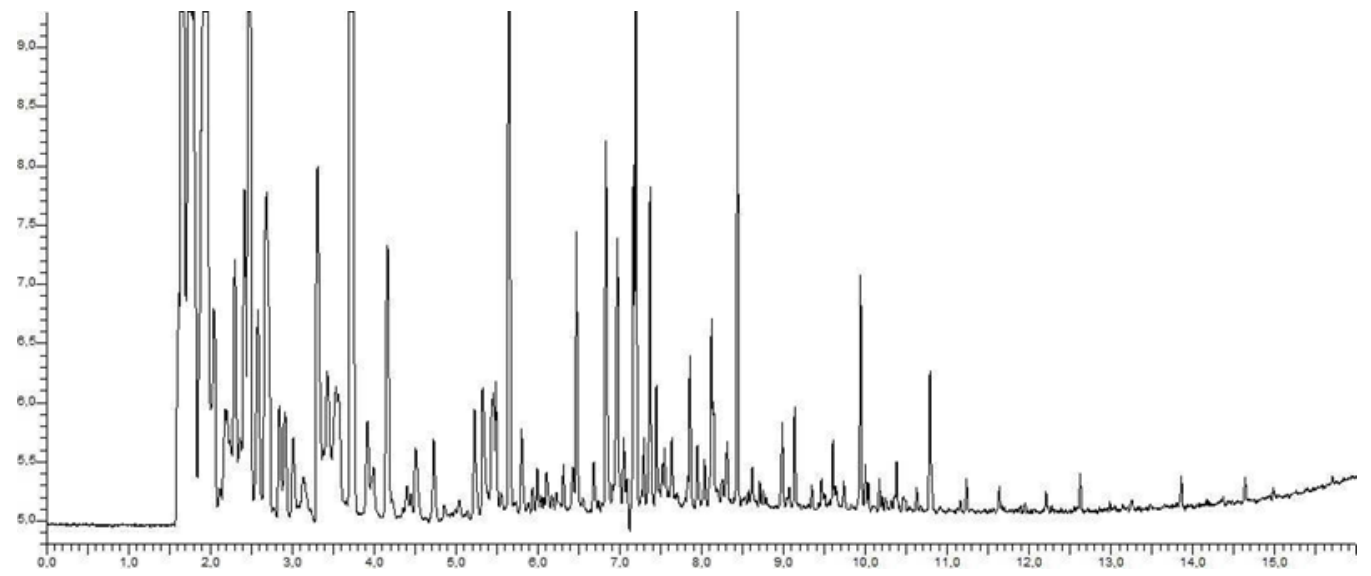

Figuur 53 Gaschromatogram van vluchtige stoffen in monster B2-kz

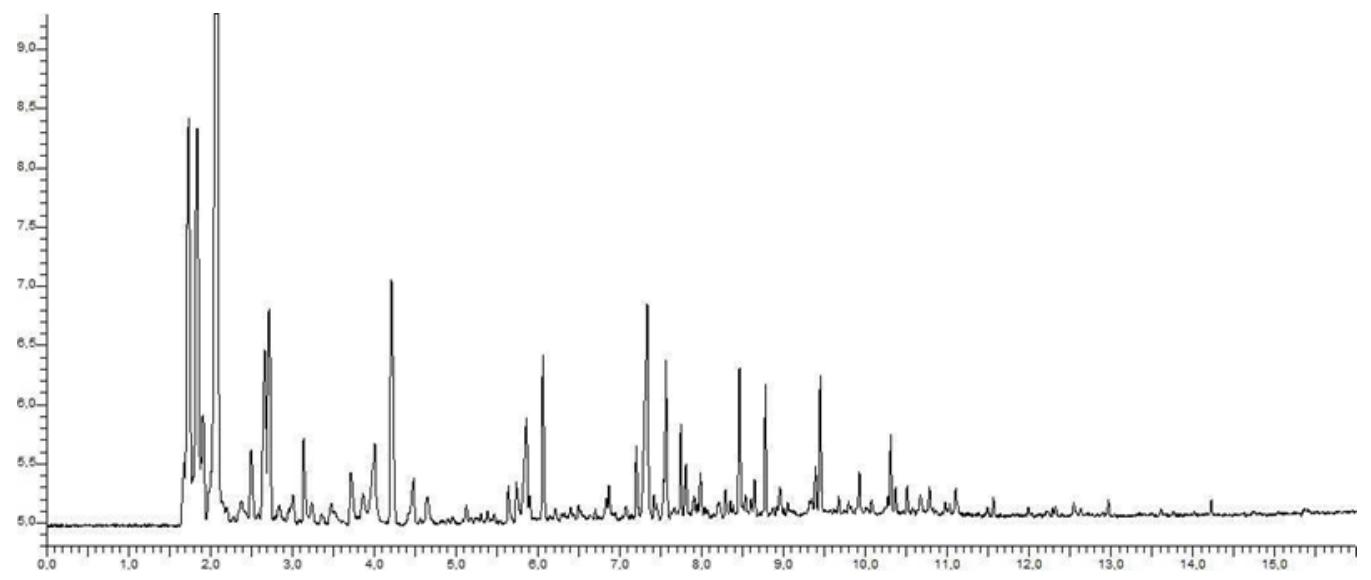

Figuur 54 Gaschromatogram van vluchtige stoffen in monster B2-kz-e

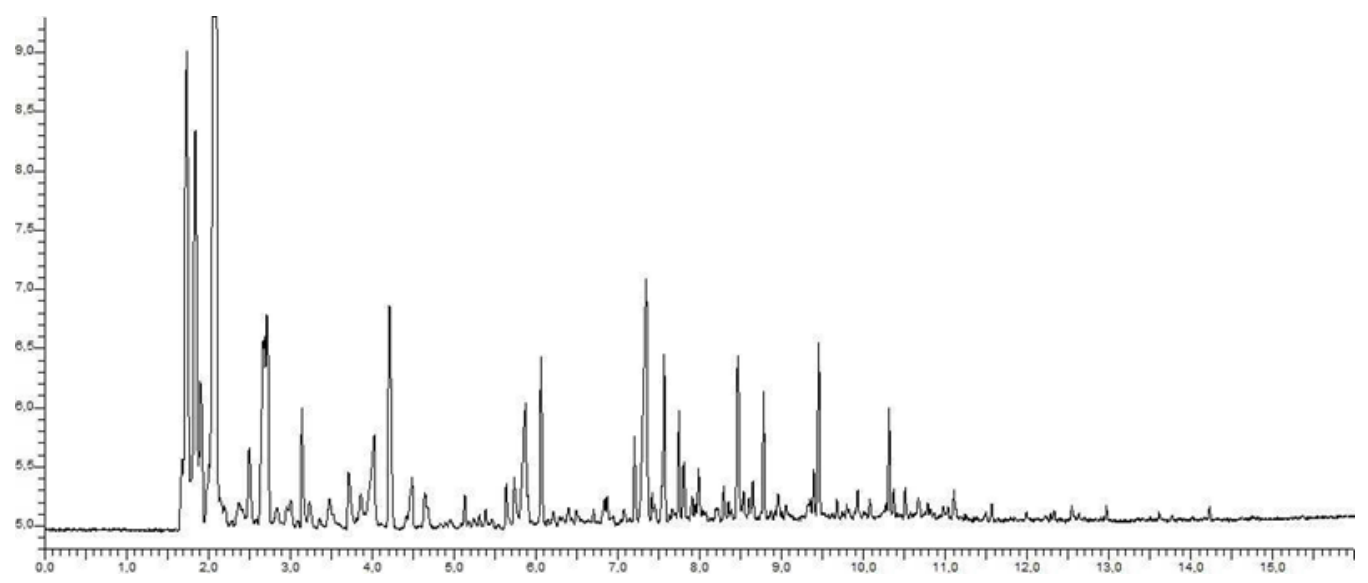

Figuur 55 Gaschromatogram van vluchtige stoffen in monster B2-kz-ev 


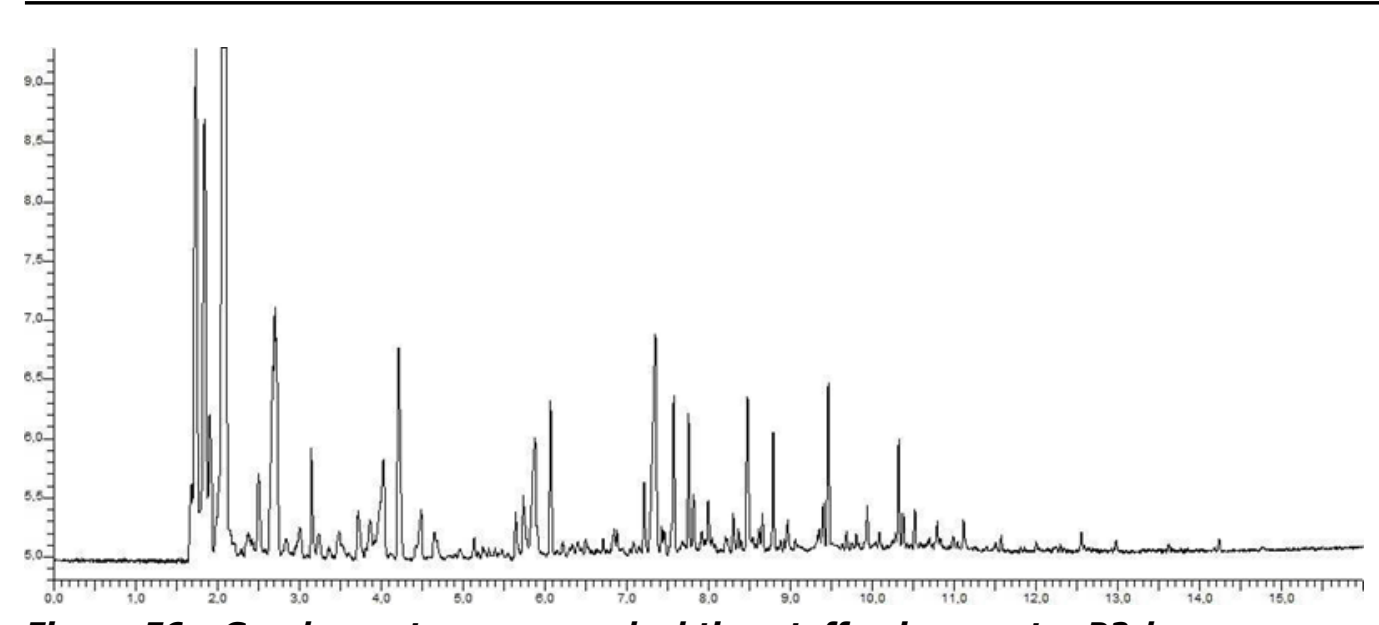

Figuur 56 Gaschromatogram van vluchtige stoffen in monster B2-km-e

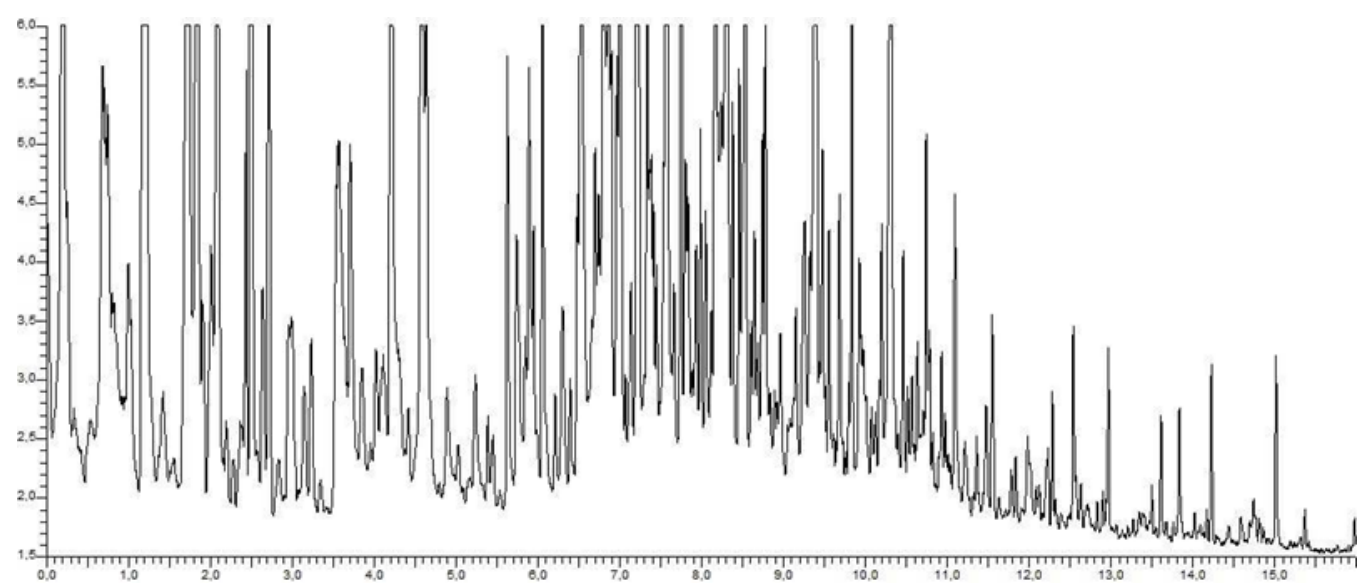

Figuur 57 Gaschromatogram van vluchtige stoffen in monster B2-wz-e. Dit chromatogram moet buiten beschouwing gelaten worden in verband met analytische problemen

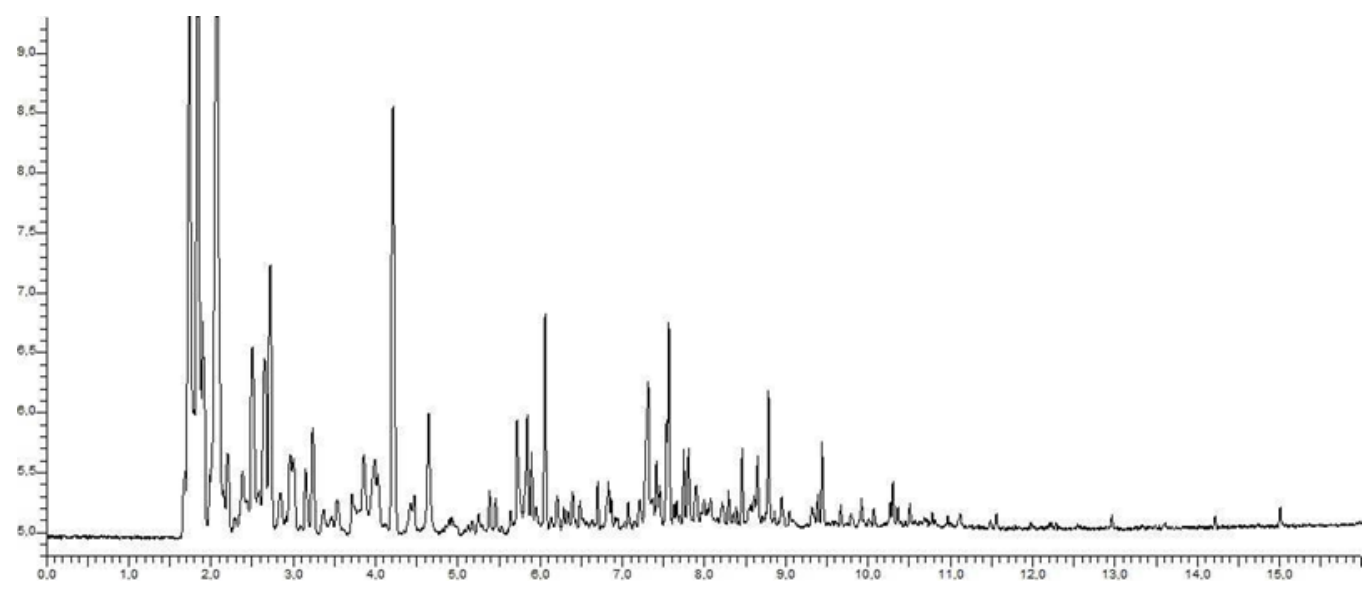

Figuur 58 Gaschromatogram van vluchtige stoffen in monster B2-wm-e 

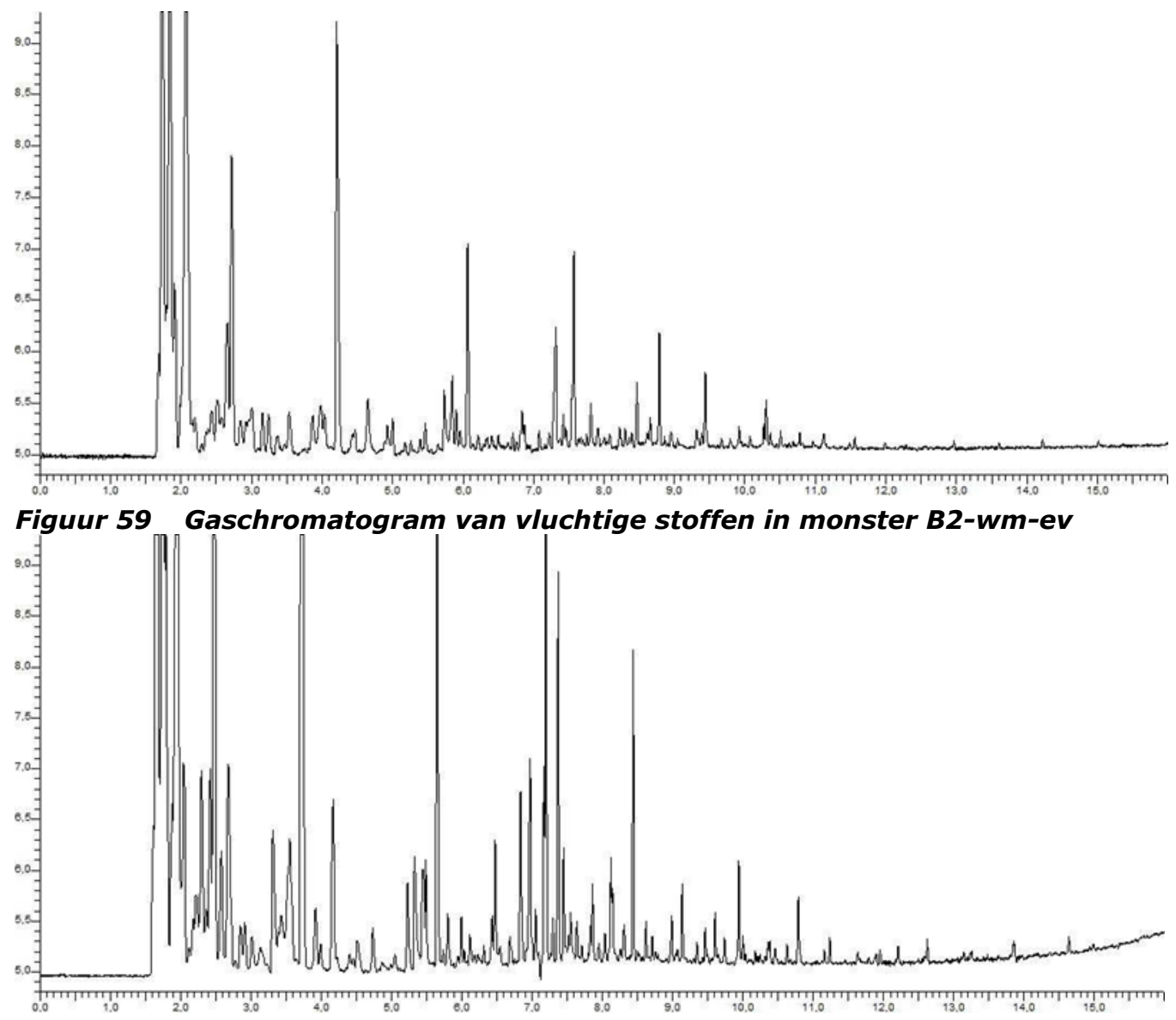

Figuur 60 Gaschromatogram van vluchtige stoffen in monster N2-kz

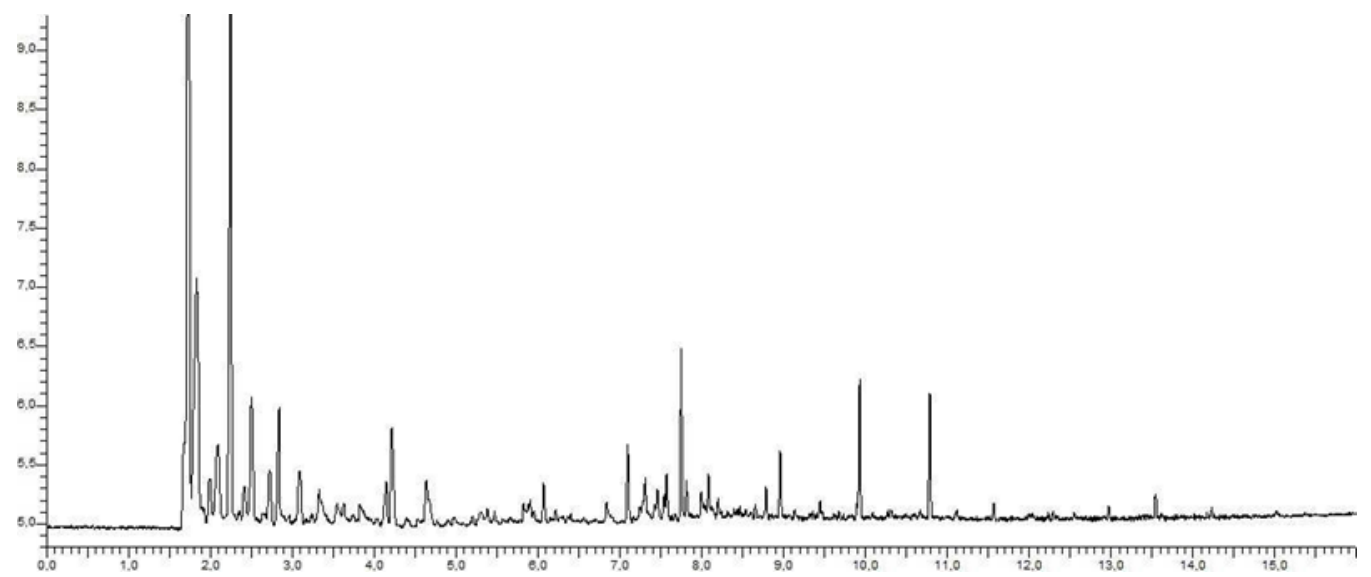

Figuur 61 Gaschromatogram van vluchtige stoffen in monster N2-kz-e

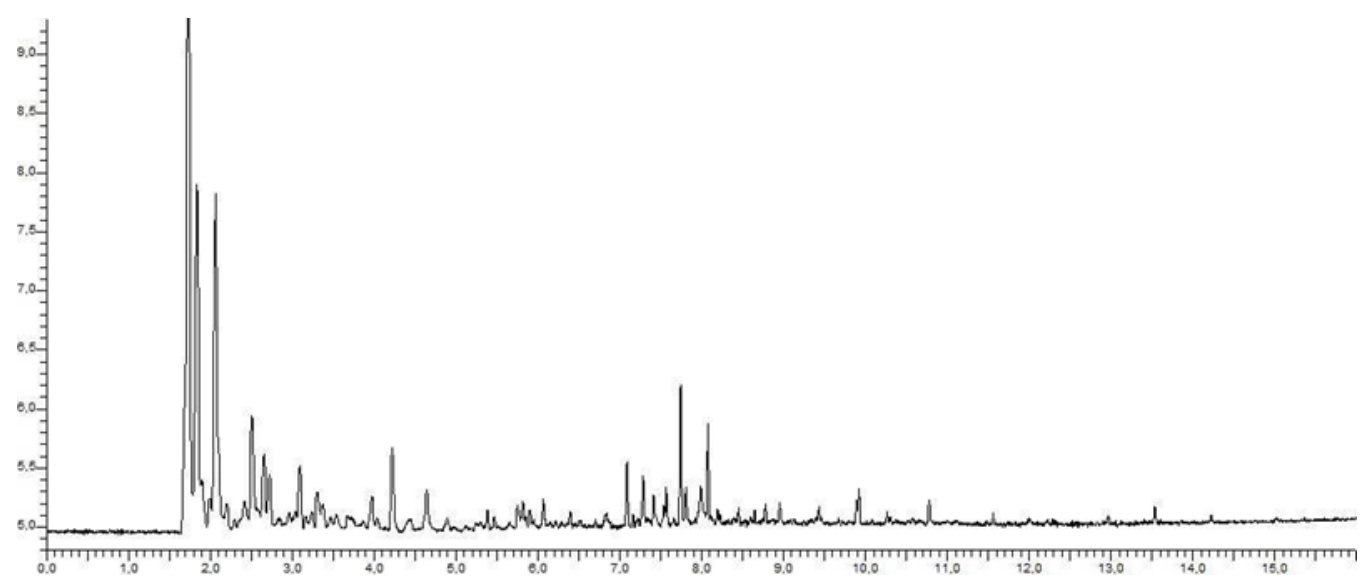

Figuur 62 Gaschromatogram van vluchtige stoffen in monster N2-kz-ev 


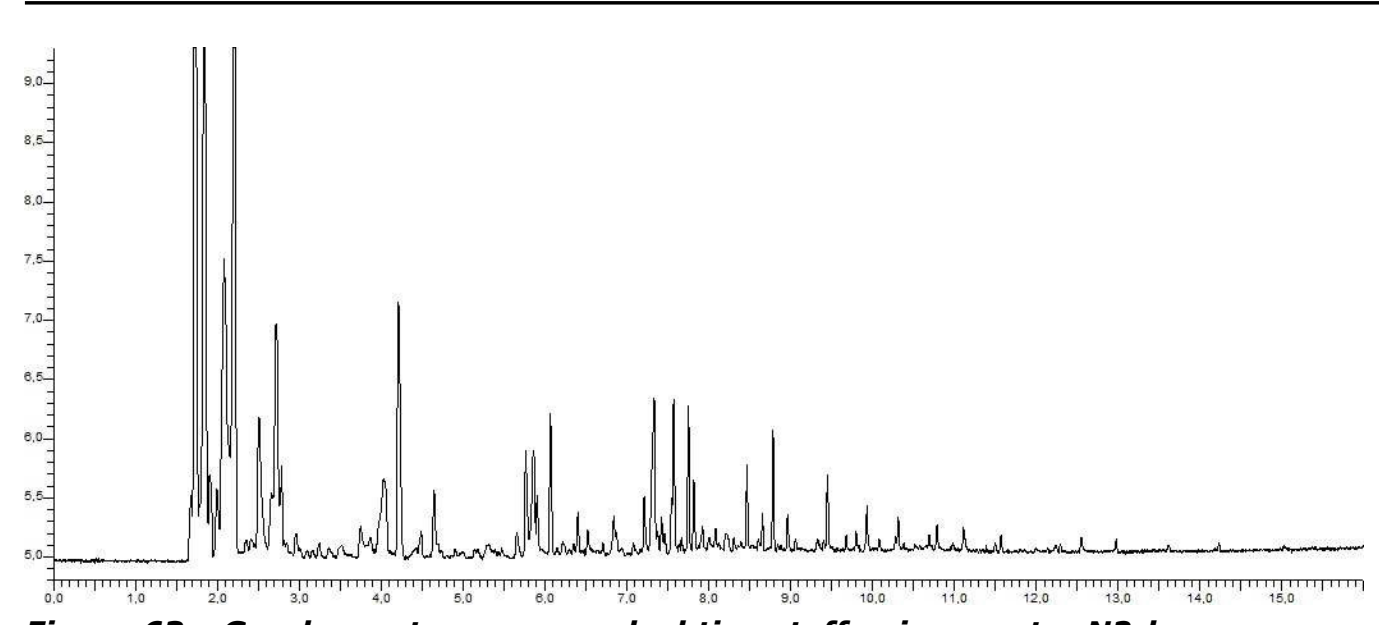

Figuur 63 Gaschromatogram van vluchtige stoffen in monster N2-km-e

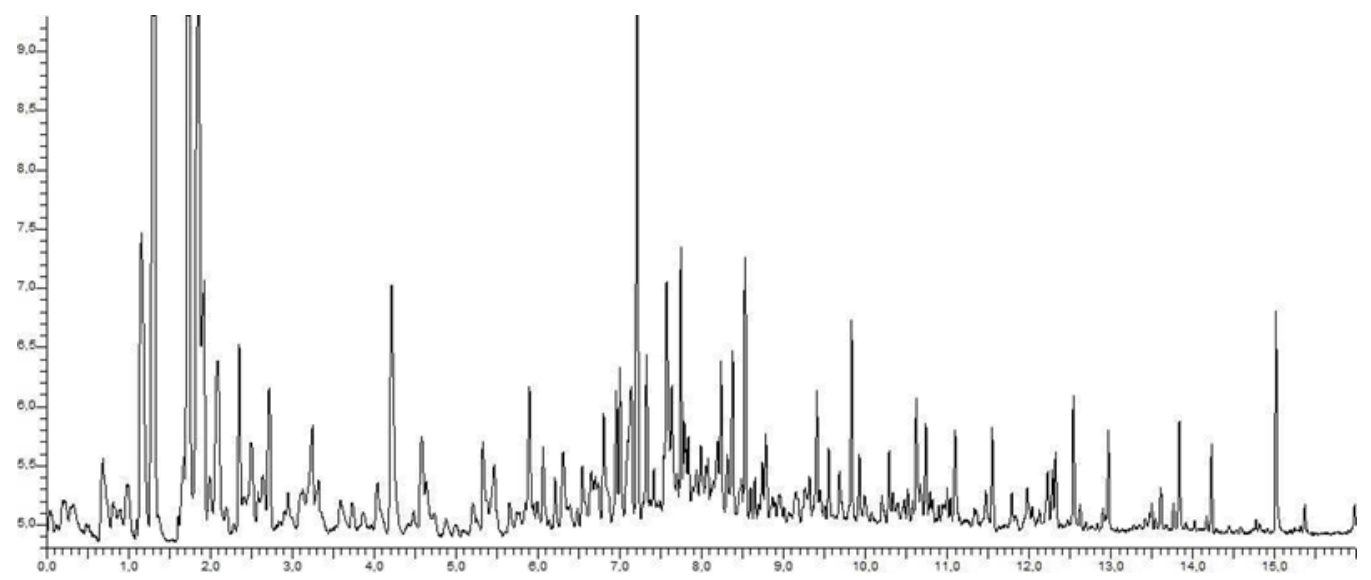

Figuur 64 Gaschromatogram van vluchtige stoffen in monster N2-wz-e. Dit chromatogram moet buiten beschouwing gelaten worden in verband met analytische problemen

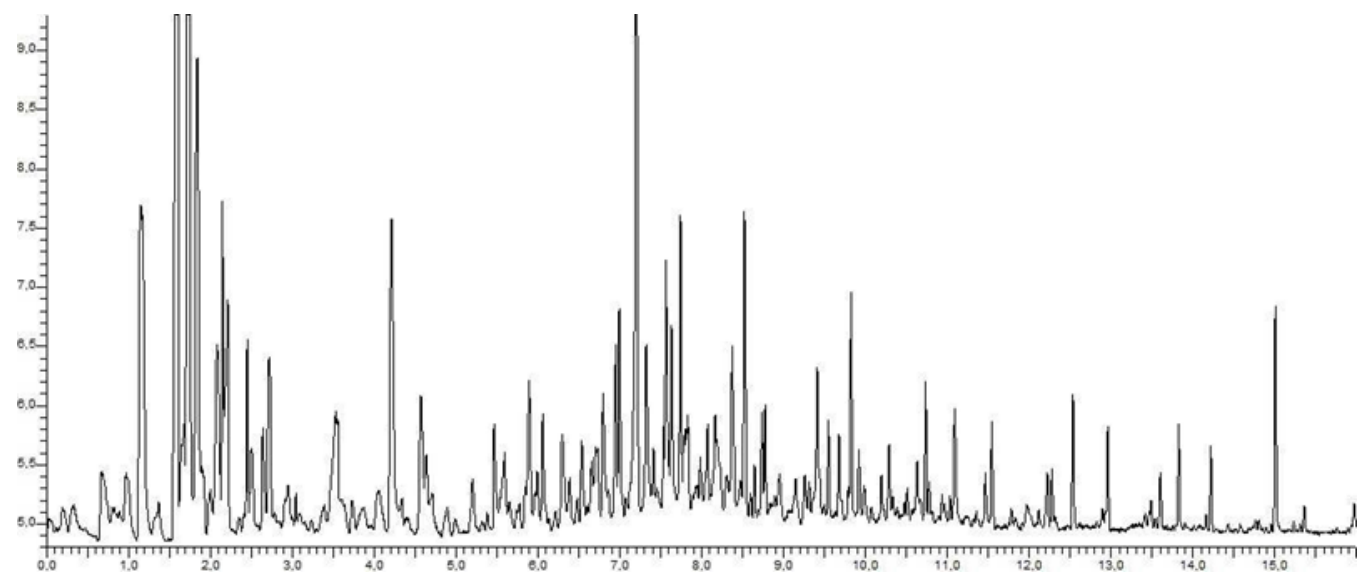

Figuur 65 Gaschromatogram van vluchtige stoffen in monster N2-wm-e. Dit chromatogram moet buiten beschouwing gelaten worden in verband met analytische problemen 


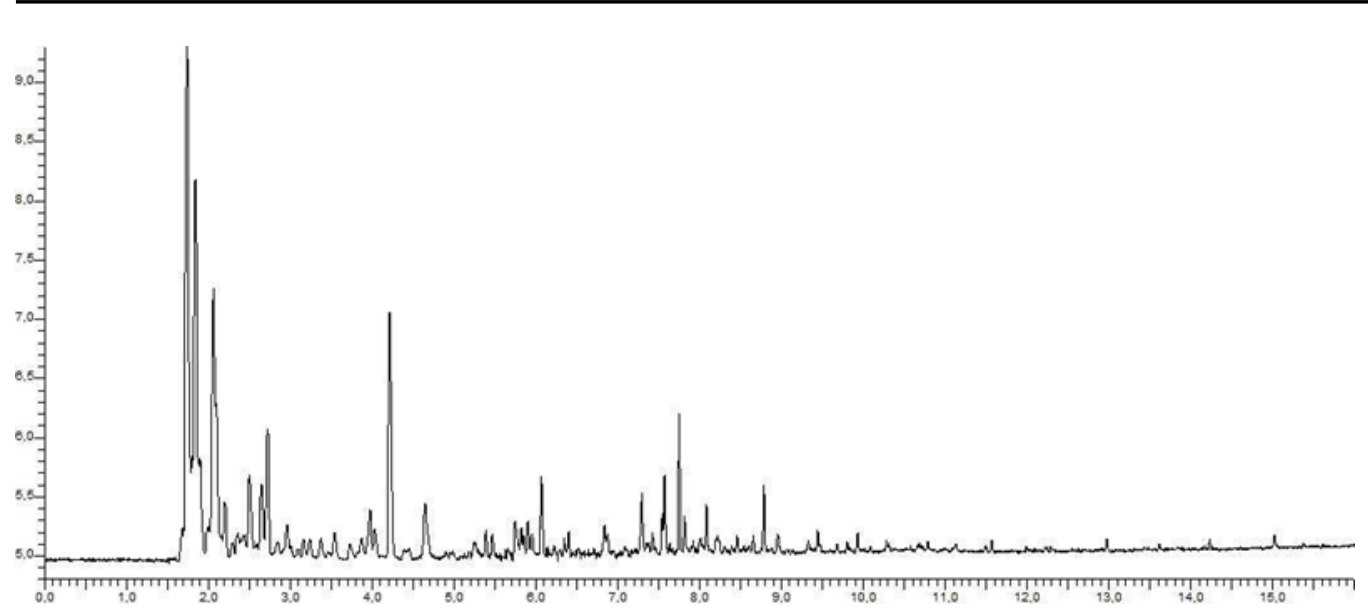

Figuur 66 Gaschromatogram van vluchtige stoffen in monster N2-wm-ev 
Gaschromatogrammen van gemiddeld tot niet vluchtige stoffen

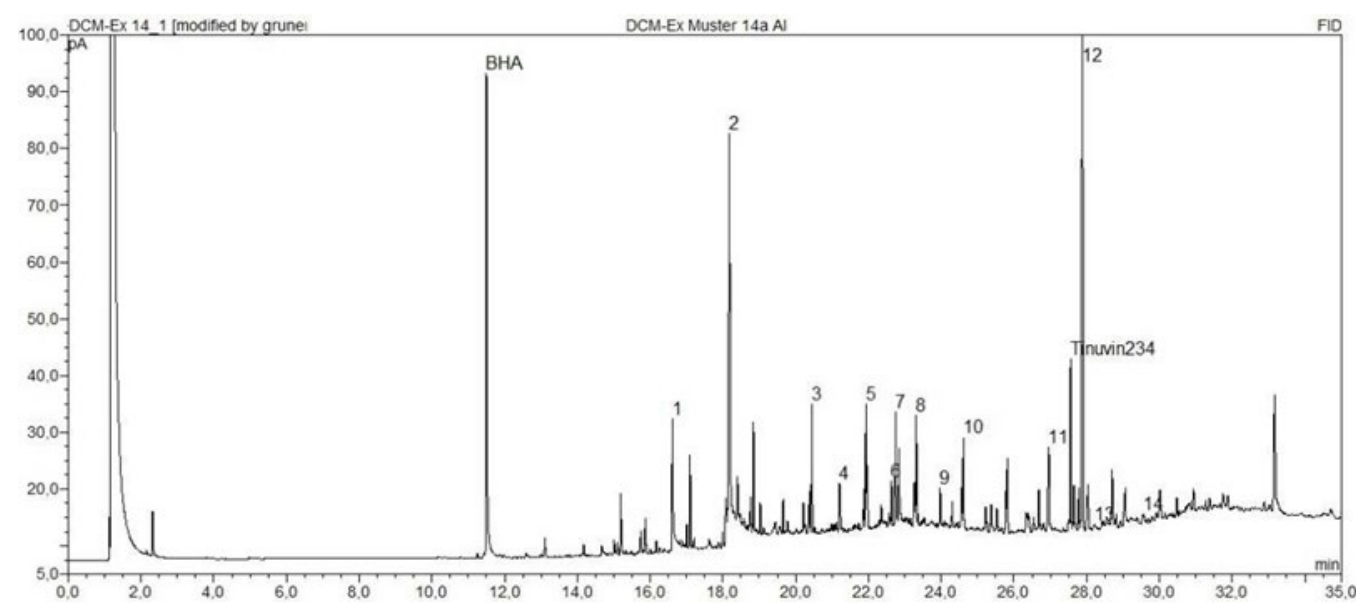

Figuur 67 Gaschromatogram van gemiddeld tot niet vluchtige stoffen in monster B2-kZ

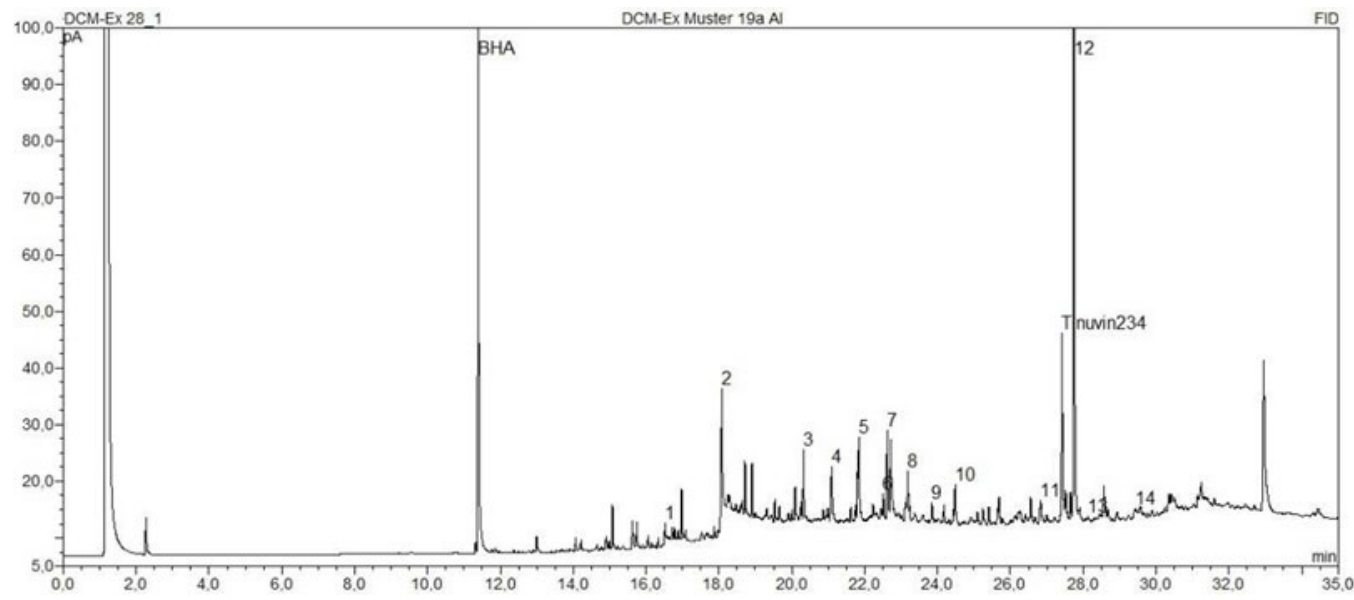

Figuur 68 Gaschromatogram van gemiddeld tot niet vluchtige stoffen in monster B2-kz-e

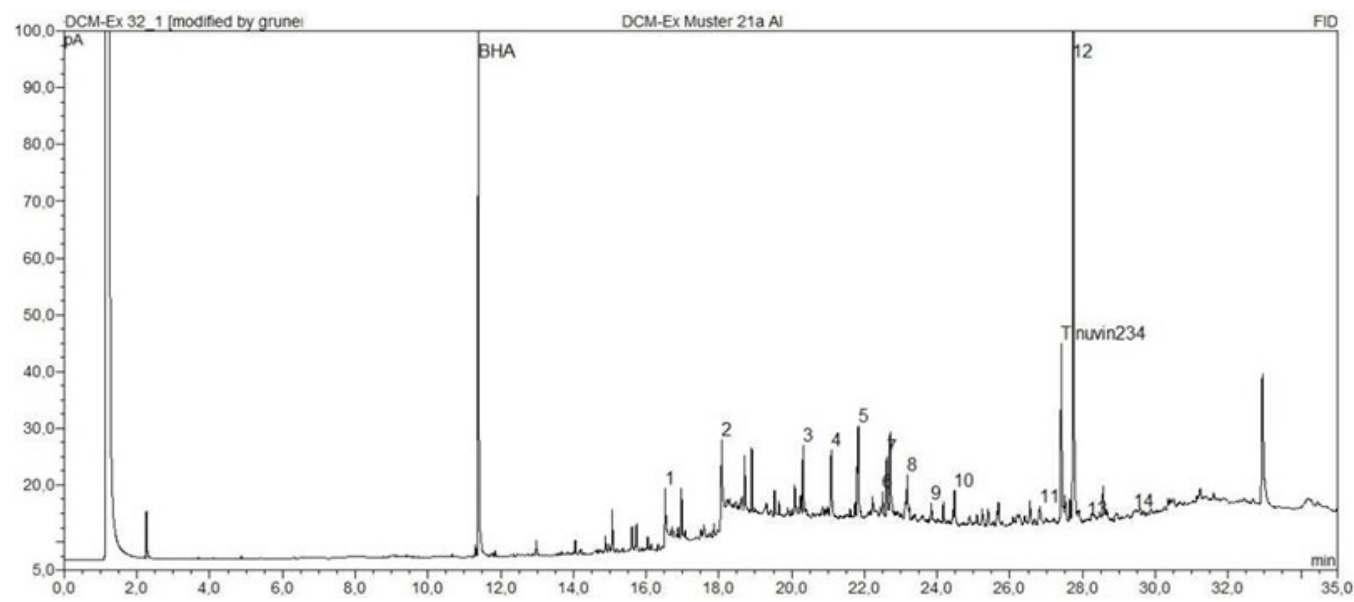

Figuur 69 Gaschromatogram van gemiddeld tot niet vluchtige stoffen in monster B2-kz-ev 


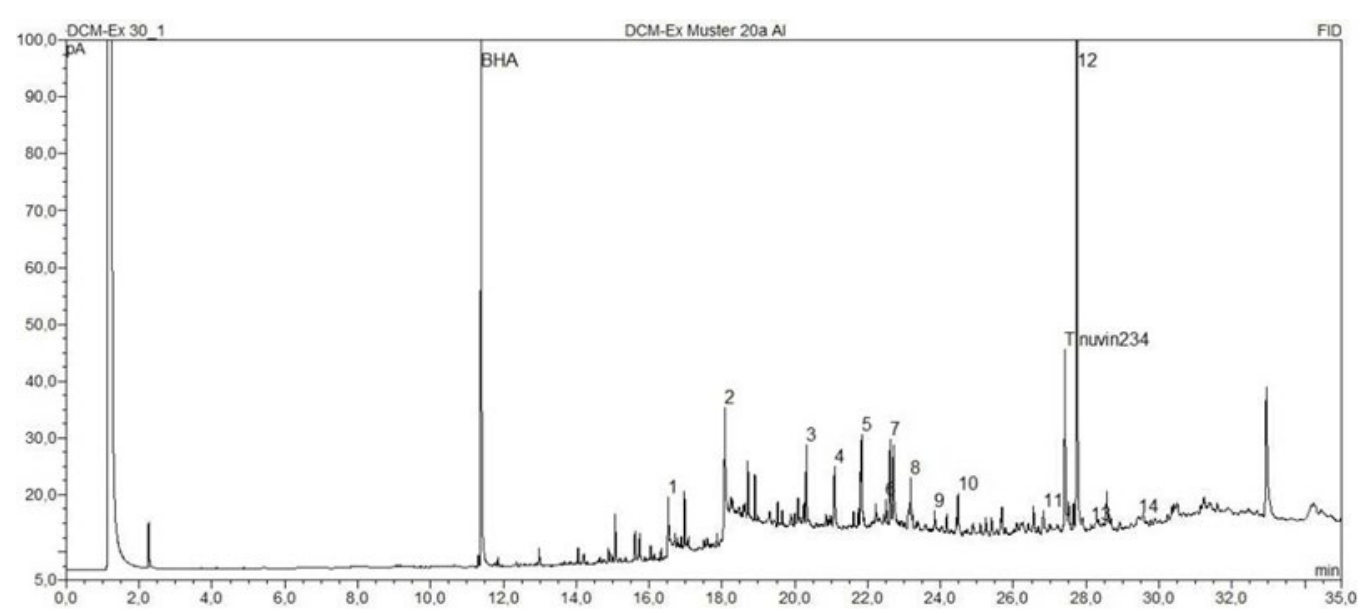

Figuur 70 Gaschromatogram van gemiddeld tot niet vluchtige stoffen in monster B2-km-e

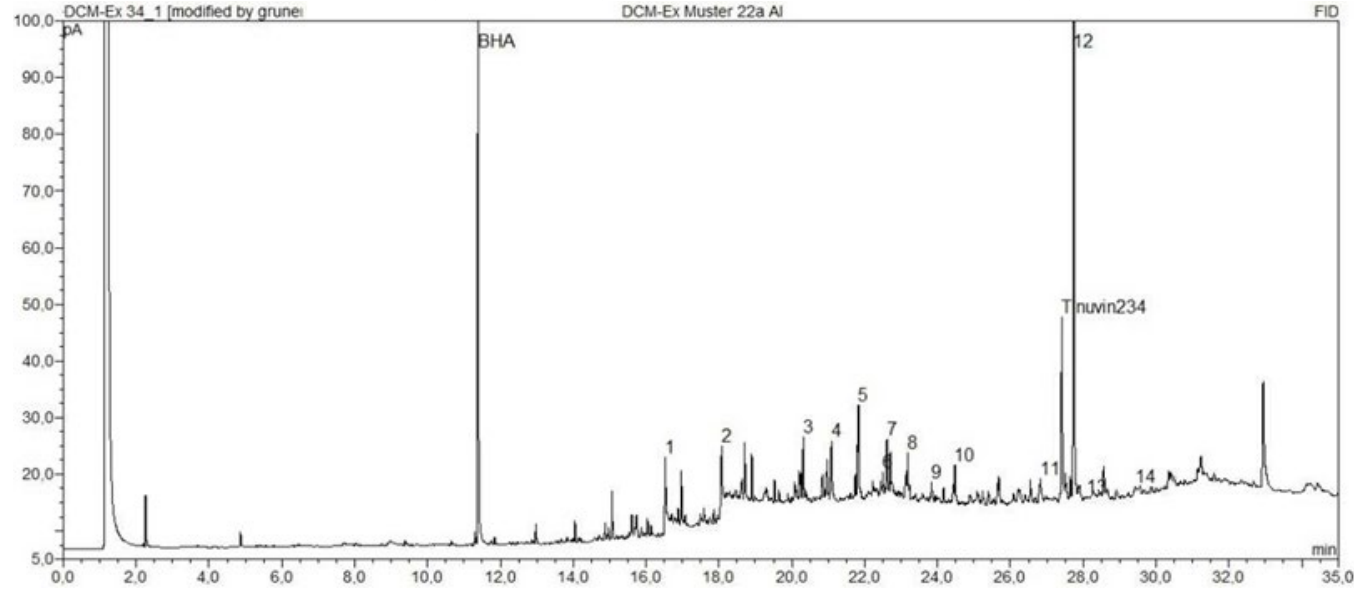

Figuur 71 Gaschromatogram van gemiddeld tot niet vluchtige stoffen in monster B2-wz-e

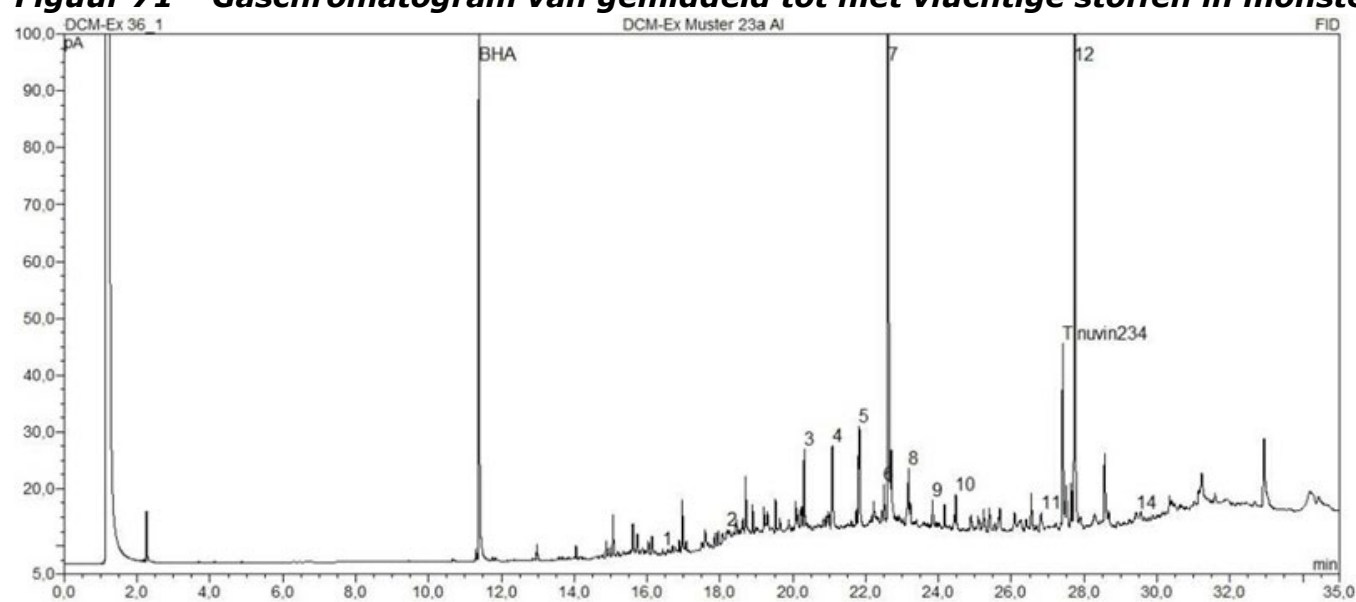

Figuur 72 Gaschromatogram van gemiddeld tot niet vluchtige stoffen in monster B2-wm-e 


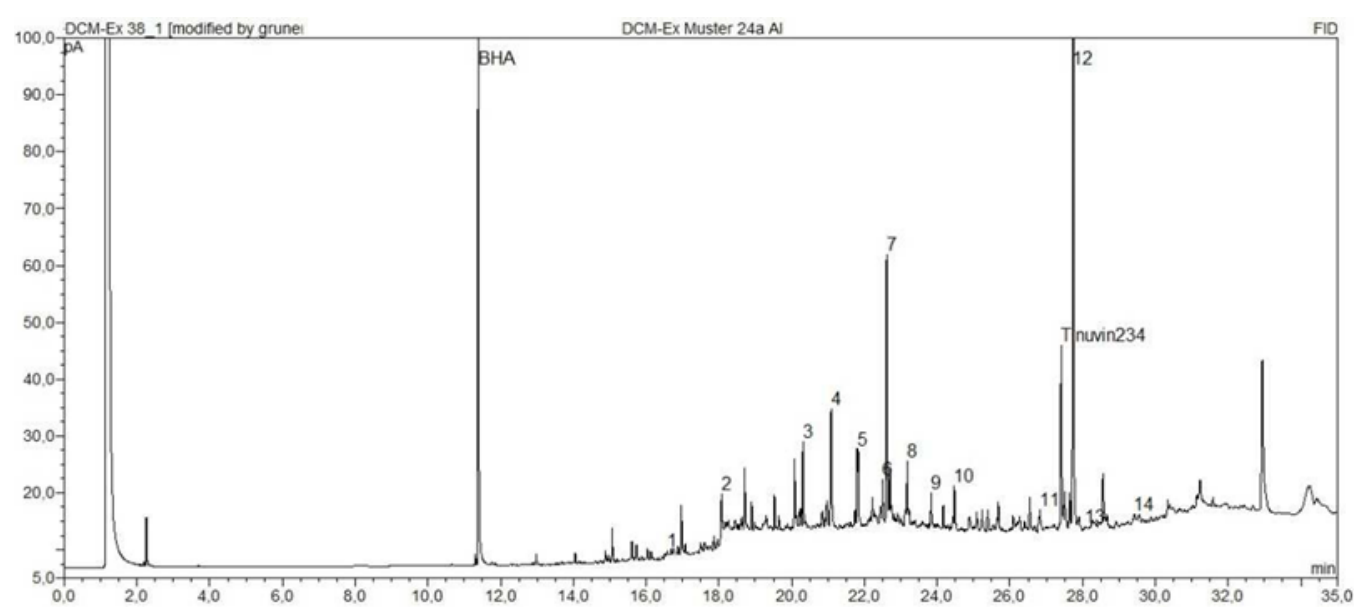

Figuur 73 Gaschromatogram van gemiddeld tot niet vluchtige stoffen in monster B2-wm-ev

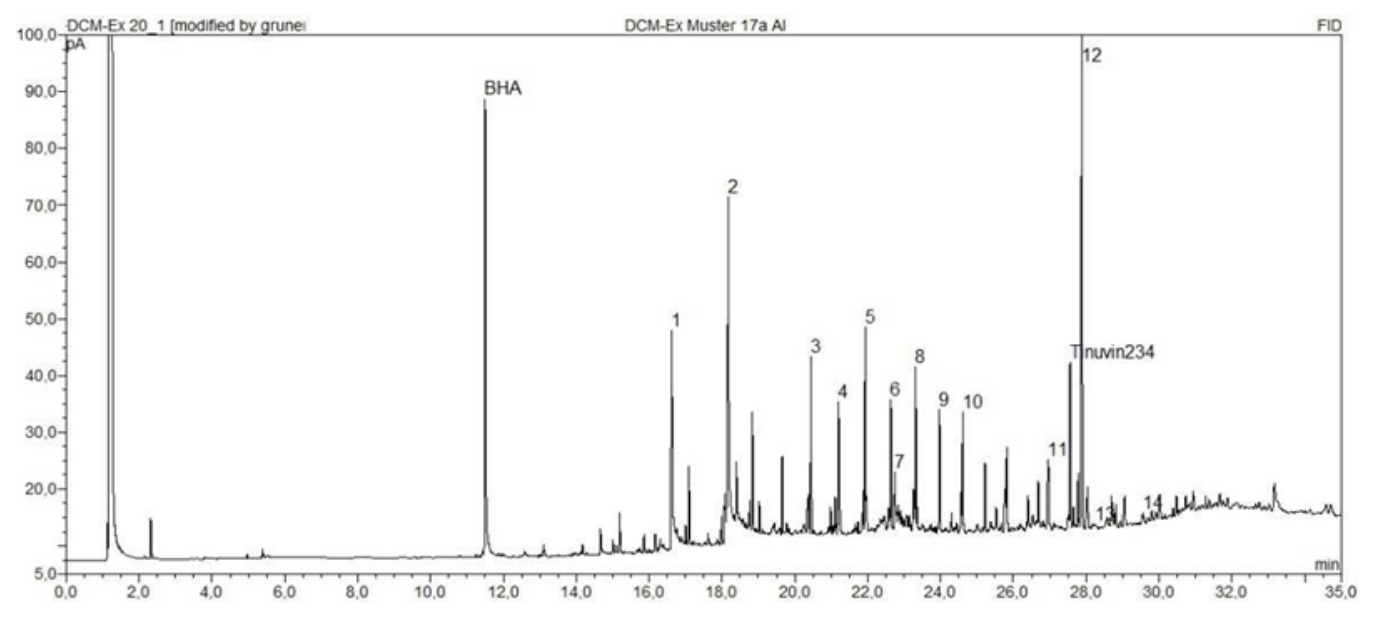

Figuur 74 Gaschromatogram van gemiddeld tot niet vluchtige stoffen in monster N2-kz

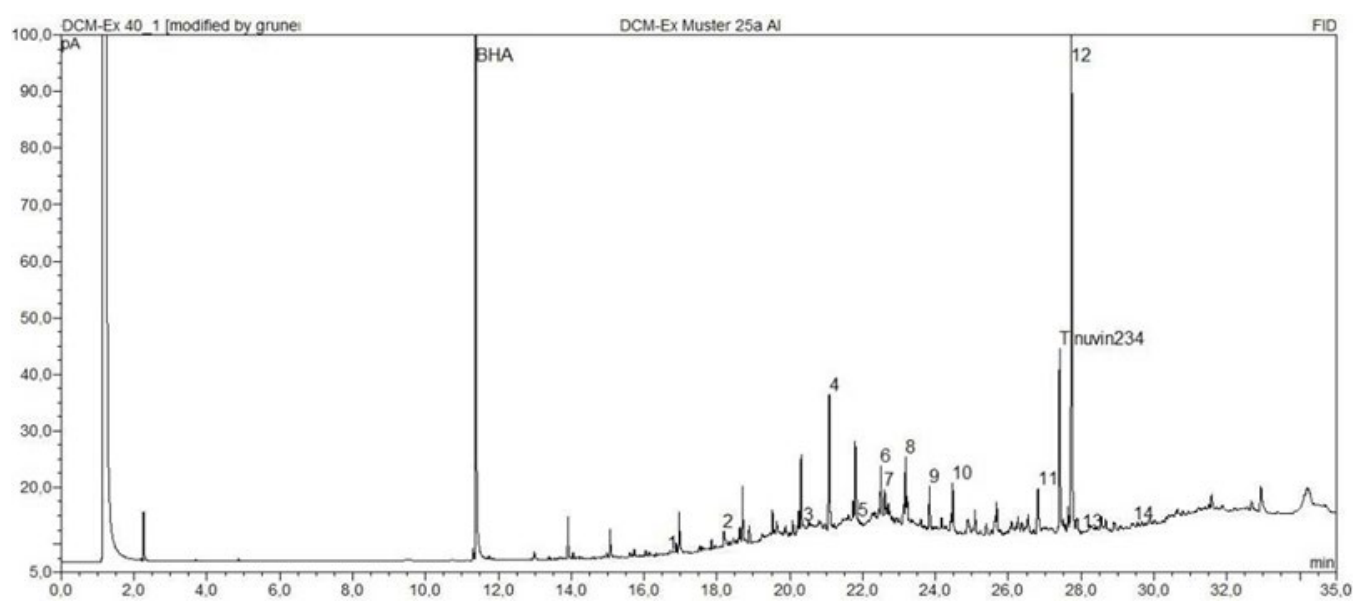

Figuur 75 Gaschromatogram van gemiddeld tot niet vluchtige stoffen in monster N2-kz-e 


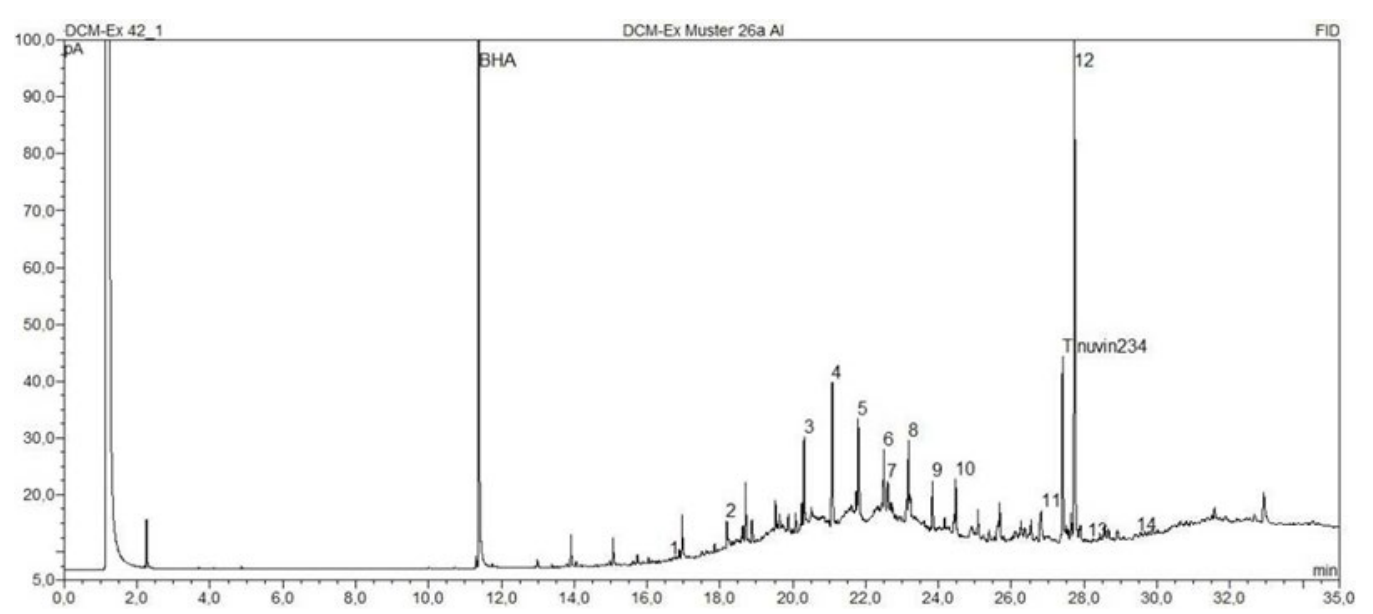

Figuur 76 Gaschromatogram van gemiddeld tot niet vluchtige stoffen in monster N2-kz-ev

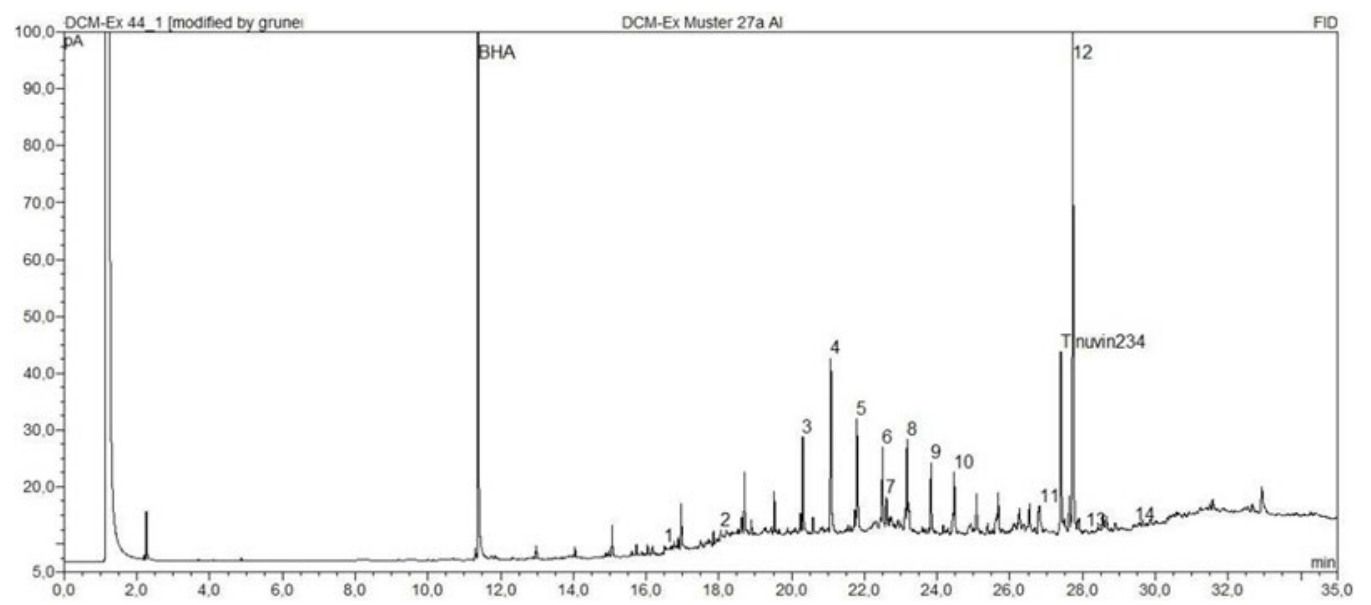

Figuur 77 Gaschromatogram van gemiddeld tot niet vluchtige stoffen in monster N2-km-e

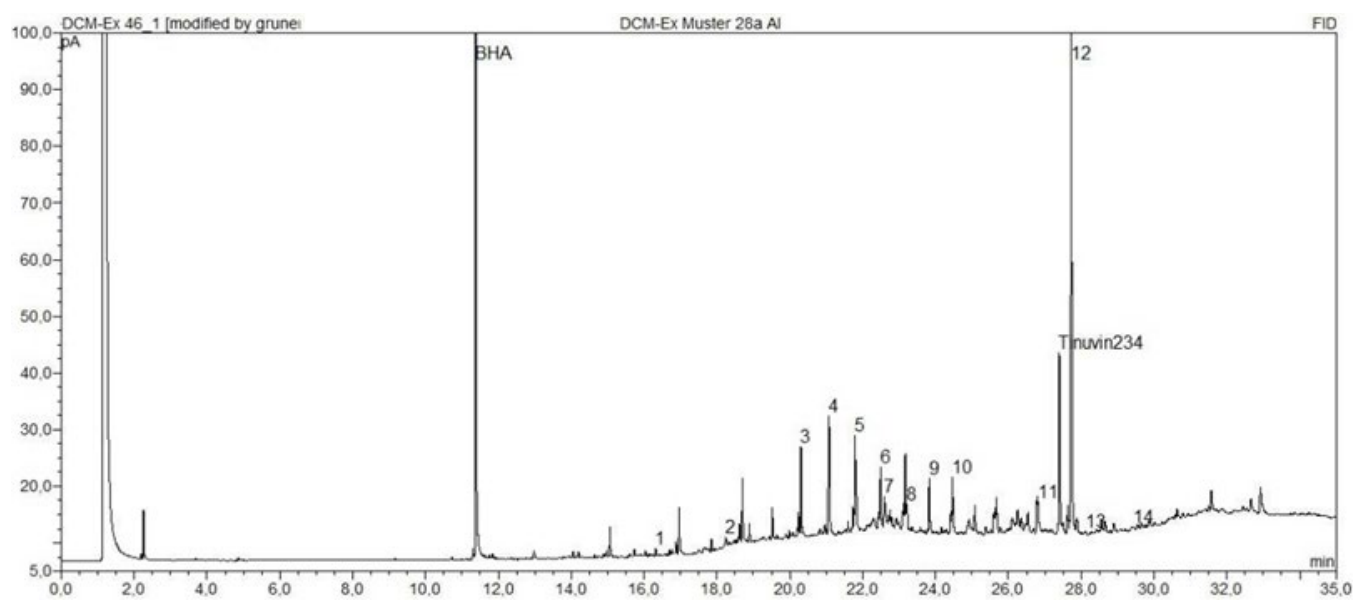

Figuur 78 Gaschromatogram van gemiddeld tot niet vluchtige stoffen in monster N2-wz-e 


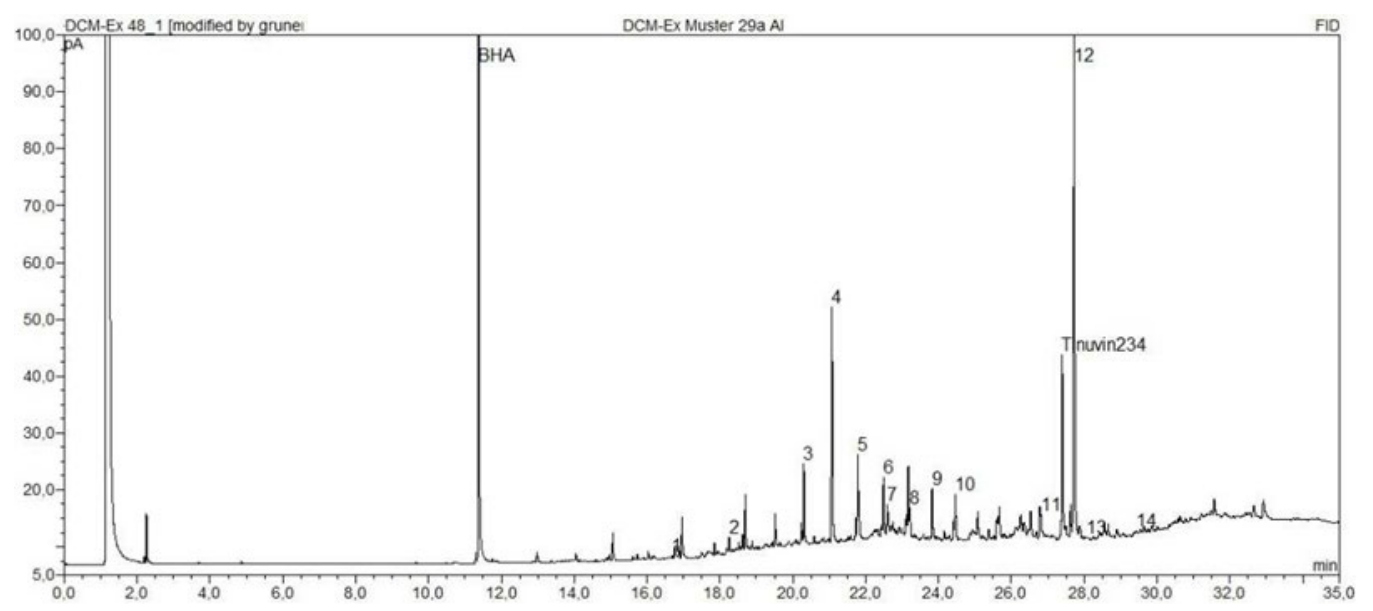

Figuur 79 Gaschromatogram van gemiddeld tot niet vluchtige stoffen in monster N2-wm-e

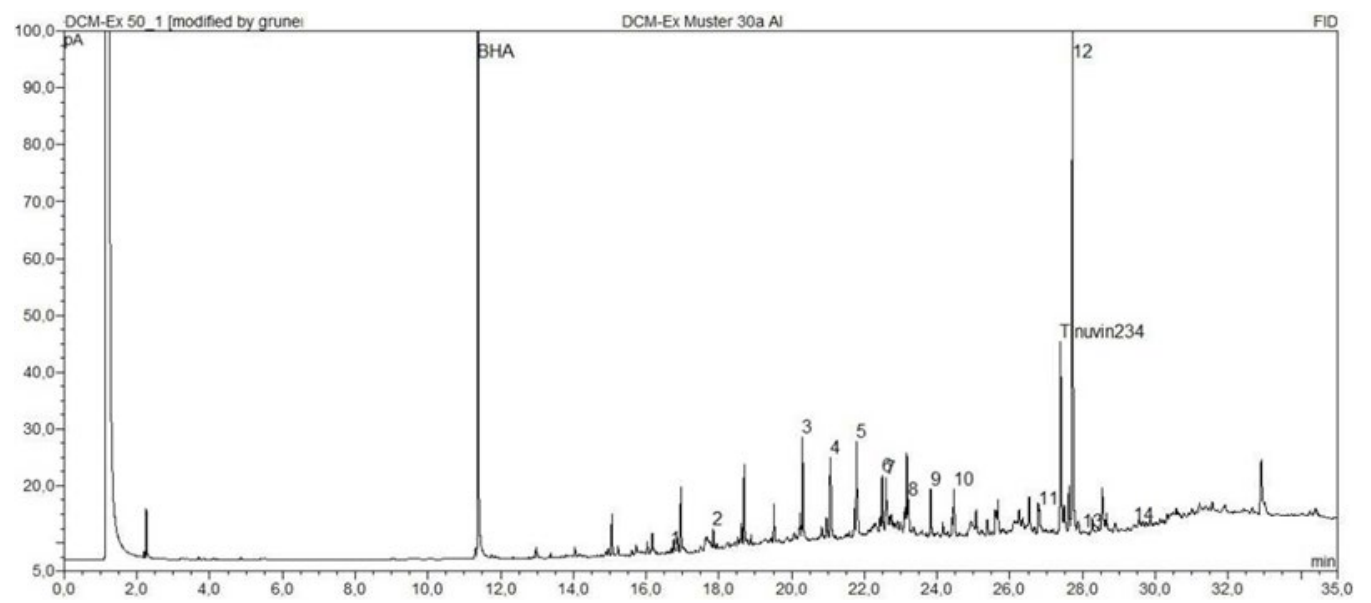

Figuur 80 Gaschromatogram van gemiddeld tot niet vluchtige stoffen in monster N2-wm-ev 


\begin{tabular}{|c|c|c|c|c|c|c|c|c|}
\hline \multirow[t]{2}{*}{ Piek } & \multirow[t]{2}{*}{$\begin{array}{l}\text { Retentie- } \\
\text { tijd (min) }\end{array}$} & \multirow[t]{2}{*}{ Identificatie } & \multicolumn{6}{|c|}{$\begin{array}{l}\text { Concentratie (mg/kg) } \\
\text { Bronscheiding }\end{array}$} \\
\hline & & & kz-e & kz-ev & km-e & wz-e & wm-e & wm-ev \\
\hline 1 & 16.6 & Hexadecaanzuur & $29.6 \pm 8.2$ & $48.8 \pm 4.7$ & $54.2 \pm 5.5$ & $70.1 \pm 10.1$ & $5.6 \pm 0.2$ & $11.9 \pm 4.8$ \\
\hline 2 & 18.2 & Oliezuur & $176 \pm 37$ & $180 \pm 55$ & $122 \pm 29$ & $95.7 \pm 4.4$ & $38.3 \pm 22.7$ & $65.9 \pm 11.4$ \\
\hline 3 & 20.4 & Koolwaterstof " 3 " & $62.2 \pm 2.8$ & $75.9 \pm 21.4$ & $64.5 \pm 5.8$ & $64.4 \pm 12.5$ & $66.8 \pm 1.6$ & $75.7 \pm 13.2$ \\
\hline 4 & 21.2 & $\begin{array}{l}\text { Bis(2-ethylhexyl) } \\
\text { adipaat (DEHA) }\end{array}$ & $83.1 \pm 4.4$ & $73.5 \pm 5.5$ & $80.4 \pm 1.9$ & $79.8 \pm 4.7$ & $98.9 \pm 2.4$ & $134.5 \pm 6.5$ \\
\hline 5 & 21.9 & $\begin{array}{l}\text { Bis(2-ethylhexyl) } \\
\text { ftalaat (DEHP) }\end{array}$ & $81.4 \pm 4.7$ & $73.3 \pm 8.2$ & $75.1 \pm 2.4$ & $89.0 \pm 30.0$ & $86.2 \pm 3.3$ & $75.0 \pm 4.5$ \\
\hline 6 & 22.6 & Koolwaterstof "6" & $27.5 \pm 7.3$ & $21.8 \pm 5.9$ & $19.4 \pm 4.2$ & $26.9 \pm 8.2$ & $24.8 \pm 16.8$ & $53.1 \pm 3.8$ \\
\hline 7 & 22.7 & $\begin{array}{l}\text { Bis(2-ethylhexyl) } \\
\text { Tereftalaat (DEHT) }\end{array}$ & $88.5 \pm 6.4$ & $78.1 \pm 5.7$ & $54.5 \pm 4.3$ & $74.8 \pm 16.4$ & $653 \pm 35.9$ & $244 \pm 7.0$ \\
\hline 8 & 23.3 & Koolwaterstof " 8 " & $74.1 \pm 11.6$ & $68.0 \pm 11.1$ & $55.0 \pm 11.6$ & $60.0 \pm 19.6$ & $75.4 \pm 0.9$ & $98.9 \pm 14.3$ \\
\hline 9 & 24.0 & Koolwaterstof "9" & $25.7 \pm 3.4$ & $26.0 \pm 2.3$ & $23.2 \pm 3.4$ & $28.3 \pm 5.9$ & $27.8 \pm 1.0$ & $39.8 \pm 12.7$ \\
\hline 10 & 24.6 & Koolwaterstof " 10 " & $38.8 \pm 7.9$ & $42.4 \pm 2.1$ & $29.9 \pm 5.9$ & $35.3 \pm 7.7$ & $33.0 \pm 1.1$ & $32.1 \pm 7.9$ \\
\hline 11 & 27.0 & Koolwaterstof " 11 " & $40.8 \pm 2.8$ & $40.0 \pm 1.4$ & $32.7 \pm 1.9$ & $31.5 \pm 3.5$ & $22.5 \pm 1.7$ & $31.3 \pm 12.2$ \\
\hline 12 & 27.9 & $\begin{array}{l}\text { Geoxideerd Irgafos } \\
168\end{array}$ & $731 \pm 17.9$ & $691 \pm 14.0$ & $691 \pm 11.7$ & $535 \pm 10.1$ & $604 \pm 10.6$ & $581 \pm 14.7$ \\
\hline 13 & 28.2 & Koolwaterstof "13" & $8.8 \pm 6.6$ & $3.6 \pm 1.8$ & $5.6 \pm 2.2$ & $7.1 \pm 5.9$ & $3.5 \pm 4.5$ & $7.6 \pm 3.2$ \\
\hline 14 & 29.5 & Koolwaterstof "14" & $31.8 \pm 12.1$ & $31.6 \pm 14.9$ & $18.2 \pm 6.9$ & $38.5 \pm 18.9$ & $26.8 \pm 4.9$ & $25.2 \pm 7.4$ \\
\hline
\end{tabular}

Tabel 17 Kwantificatie van de aangetroffen gemiddeld tot niet vluchtige stoffen in folies afkomstig uit nascheiding.

\begin{tabular}{|c|c|c|c|c|c|c|c|c|}
\hline \multirow[t]{3}{*}{ Piek } & \multirow{3}{*}{$\begin{array}{l}\text { Retentie- } \\
\text { tijd (min) }\end{array}$} & \multirow[t]{3}{*}{ Identificatie } & \multirow{2}{*}{\multicolumn{6}{|c|}{$\begin{array}{l}\text { Concentratie }(\mathrm{mg} / \mathrm{kg}) \\
\text { Nascheiding }\end{array}$}} \\
\hline & & & & & & & & \\
\hline & & & kz-e & kz-ev & $\mathrm{km}-\mathrm{e}$ & wz-e & wm-e & wm-ev \\
\hline 2 & 18.2 & Oliezuur & $20.7 \pm 0.2$ & $37.1 \pm 5.3$ & $14.2 \pm 8.8$ & $18.8 \pm 6.2$ & $15.4 \pm 1.1$ & $23.0 \pm 1.3$ \\
\hline 3 & 20.4 & Koolwaterstof "3" & $22.3 \pm 38.9$ & $82.8 \pm 53.2$ & $67.4 \pm 42.9$ & $79.8 \pm 7.1$ & $71.2 \pm 4.7$ & $90.4 \pm 8.8$ \\
\hline 5 & 21.9 & $\begin{array}{l}\text { Bis(2-ethylhexyl) } \\
\text { ftalaat (DEHP) }\end{array}$ & $47.7 \pm 54.4$ & $98.6 \pm 120$ & $129 \pm 16.6$ & $116 \pm 4.6$ & $90.0 \pm 2.7$ & $52.1 \pm 58.5$ \\
\hline 6 & 22.6 & Koolwaterstof " 6 " & $40.6 \pm 8.2$ & $83.1 \pm 57.0$ & $86.0 \pm 17.1$ & $65.7 \pm 10.6$ & $85.6 \pm 19.3$ & $60.9 \pm 15.9$ \\
\hline 8 & 23.3 & Koolwaterstof " 8 " & $80.8 \pm 23.1$ & $102 \pm 20.4$ & $29.4 \pm 47.3$ & $8.6 \pm 0.3$ & $39.4 \pm 3.1$ & $20.6 \pm 13.3$ \\
\hline 9 & 24.0 & Koolwaterstof "9" & $36.0 \pm 2.0$ & $44.9 \pm 0.9$ & $64.1 \pm 4.9$ & $49.3 \pm 1.5$ & $49.3 \pm 1.1$ & $43.2 \pm 2.1$ \\
\hline 10 & 24.6 & Koolwaterstof " 10 " & $43.8 \pm 0.7$ & $49.9 \pm 0.7$ & $60.8 \pm 16.8$ & $53.5 \pm 3.1$ & $41.4 \pm 10.3$ & $46.2 \pm 1.7$ \\
\hline 11 & 27.0 & Koolwaterstof " 11 " & $77.1 \pm 6.2$ & $43.0 \pm 13.1$ & $43.9 \pm 12.3$ & $57.6 \pm 17.6$ & $51.4 \pm 4.4$ & $32.5 \pm 5.8$ \\
\hline 12 & 27.9 & $\begin{array}{l}\text { Geoxideerd Irgafos } \\
168\end{array}$ & $540 \pm 14.8$ & $513 \pm 19.6$ & $491 \pm 3.3$ & $545 \pm 18.4$ & $531 \pm 17.8$ & $492 \pm 10.5$ \\
\hline 13 & 28.2 & Koolwaterstof " 13 " & $4.3 \pm 2.2$ & $3.9 \pm 2.3$ & $8.2 \pm 1.9$ & $4.8 \pm 1.4$ & $5.7 \pm 1.4$ & $2.4 \pm 2.6$ \\
\hline 14 & 29.5 & Koolwaterstof "14" & $5.6 \pm 3.2$ & $8.7 \pm 1.1$ & $9.2 \pm 1.9$ & $6.5 \pm 3.0$ & $4.3 \pm 1.3$ & $8.7 \pm 1.8$ \\
\hline
\end{tabular}



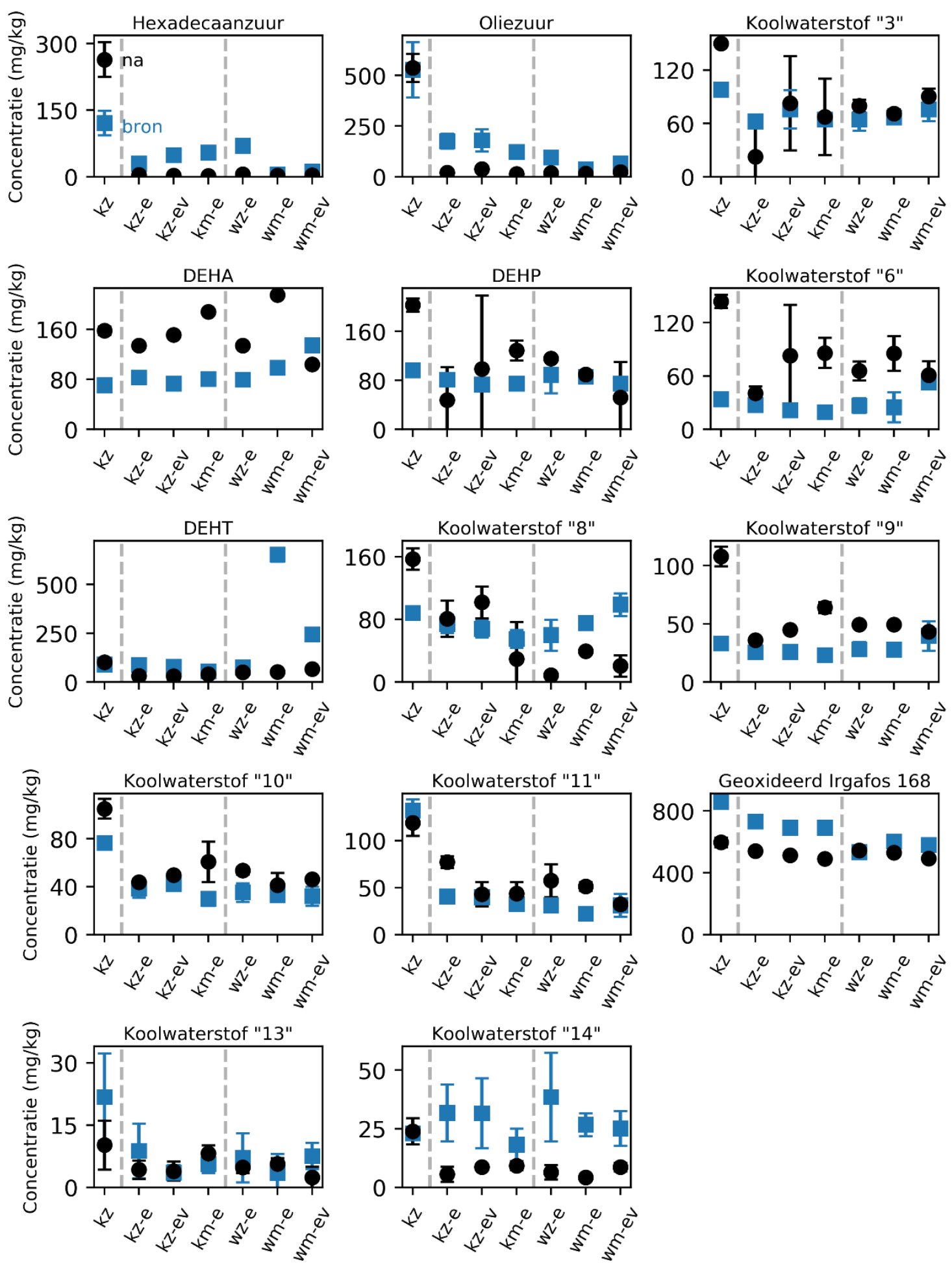

Figuur 81 Vergelijking van de concentraties van gemiddeld tot niet vluchtige stoffen tussen monsters uit bron- en nascheiding. De data van de folies uit bronscheiding is weergegeven in blauwe vierkantjes, de data van de folies uit nascheiding in zwarte rondjes 
Tabel 18 Resultaten van de ANOVA test (gemiddelde scores) en Duncan test voor folies uit bronscheiding. Verschillende letters voor een bepaalde geureigenschap betekent een significant verschil, $a \leq 0.05$ ).

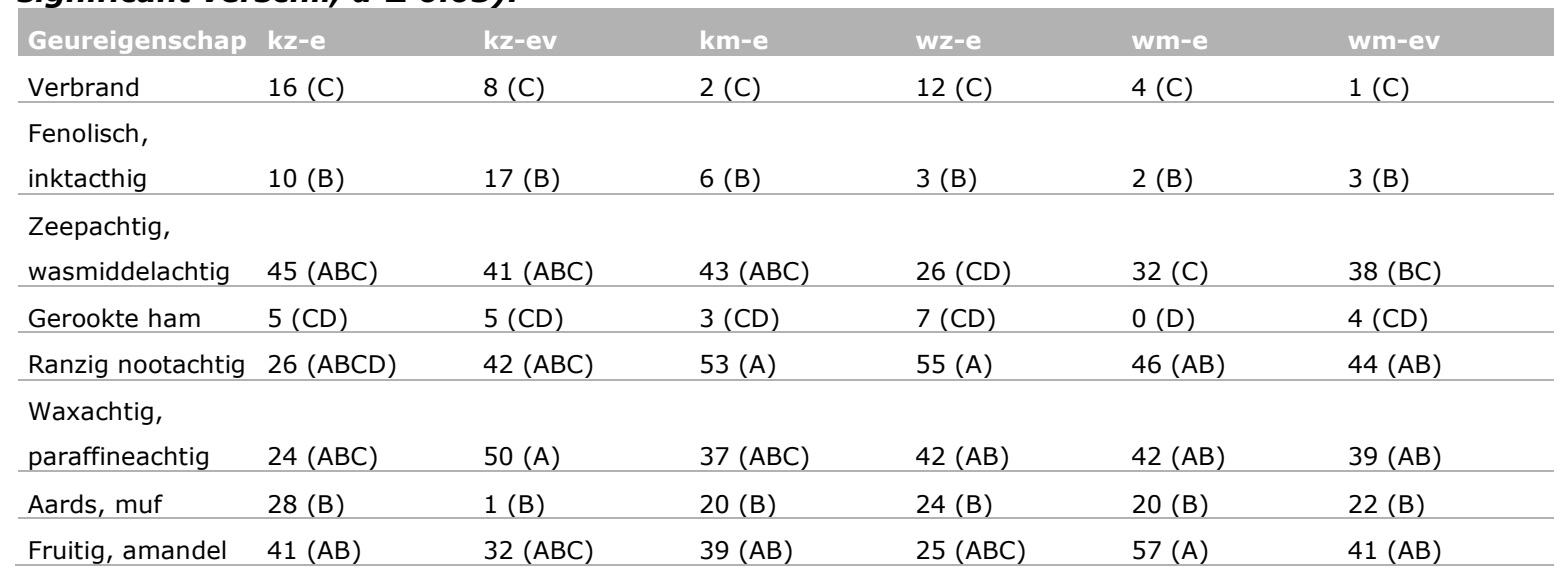

Tabel 19 Resultaten van de ANOVA test (gemiddelde scores) en Duncan test voor folies uit nascheiding. Verschillende letters voor een bepaalde geureigenschap betekent een significant verschil, $a \leq 0.05$ ).

\begin{tabular}{|c|c|c|c|c|c|c|}
\hline Geureigenschap & kz-e & kz-ev & km-e & wz-e & wm-e & wm-ev \\
\hline Verbrand & $71(\mathrm{~A})$ & $92(A)$ & $21(\mathrm{BC})$ & $38(B)$ & $14(C)$ & $6(C)$ \\
\hline $\begin{array}{l}\text { Fenolisch, } \\
\text { inktacthig }\end{array}$ & $49(A)$ & $63(\mathrm{~A})$ & $15(B)$ & $43(\mathrm{~A})$ & $16(B)$ & $10(B)$ \\
\hline $\begin{array}{l}\text { Zeepachtig, } \\
\text { wasmiddelachtig }\end{array}$ & $7(\mathrm{DE})$ & $0(E)$ & $66(A)$ & $29(\mathrm{CD})$ & $60(A B)$ & $52(A B C)$ \\
\hline Gerookte ham & $49(A)$ & $47(A)$ & $14(B C D)$ & $31(A B)$ & $23(B C)$ & $10(C D)$ \\
\hline Ranzig nootachtig & $12(\mathrm{CD})$ & $3(D)$ & $15(\mathrm{BCD})$ & $4(D)$ & $39(A B C)$ & $35(A B C)$ \\
\hline $\begin{array}{l}\text { Waxachtig, } \\
\text { paraffineachtig }\end{array}$ & $16(B C)$ & $10(C)$ & $29(A B C)$ & $18(B C)$ & $20(B C)$ & $32(A B C)$ \\
\hline Aards, muf & $2(B)$ & $6(\mathrm{~B})$ & $30(B)$ & $16(B)$ & $29(B)$ & $63(A)$ \\
\hline Fruitig, amandel & $0(\mathrm{C})$ & $1(\mathrm{C})$ & $23(A B C)$ & $14(B C)$ & $16(\mathrm{BC})$ & $18(B C)$ \\
\hline
\end{tabular}




\section{Bijlage 4 Additionele data taak 3}

Gaschromatogrammen van vluchtige stoffen

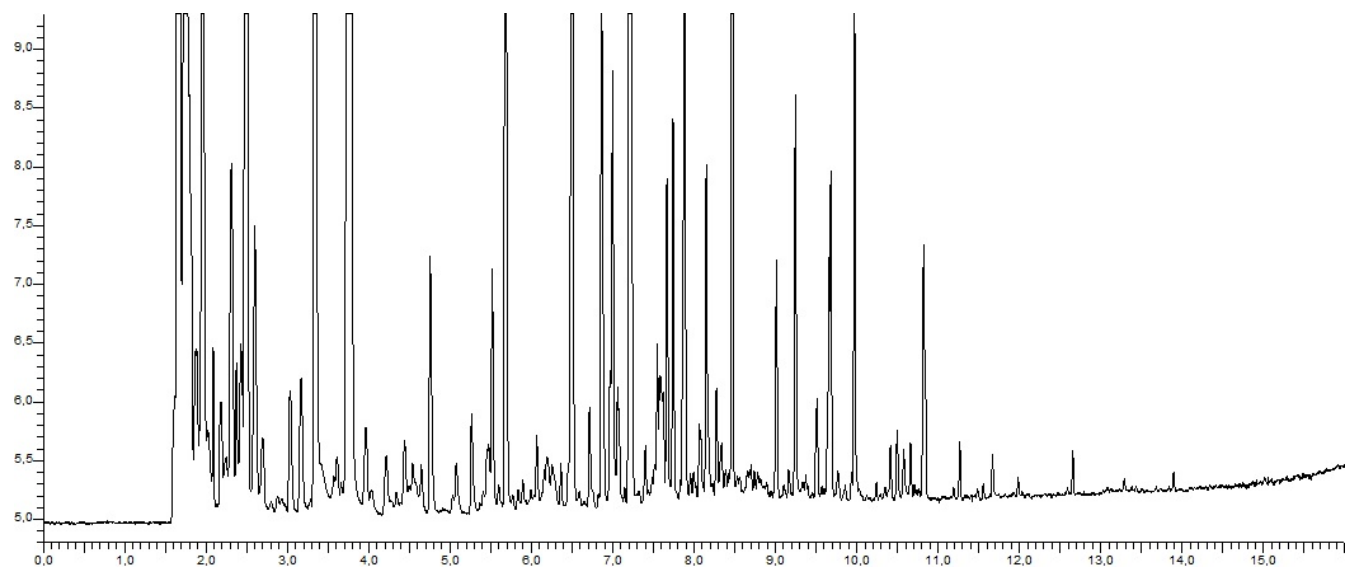

Figuur 82 Gaschromatogram van vluchtige stoffen in monster TK3-1

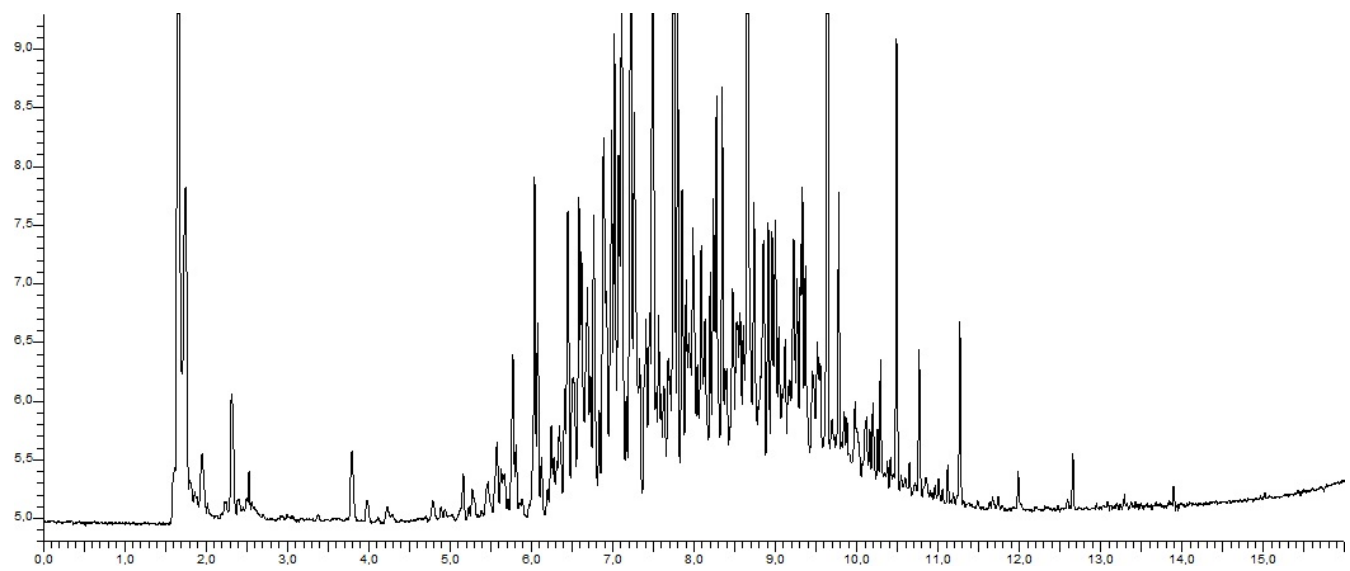

Figuur 83 Gaschromatogram van vluchtige stoffen in monster TK3-2. De hogere concentratie vluchtige stoffen kan worden verklaard door aangetroffen verfresten

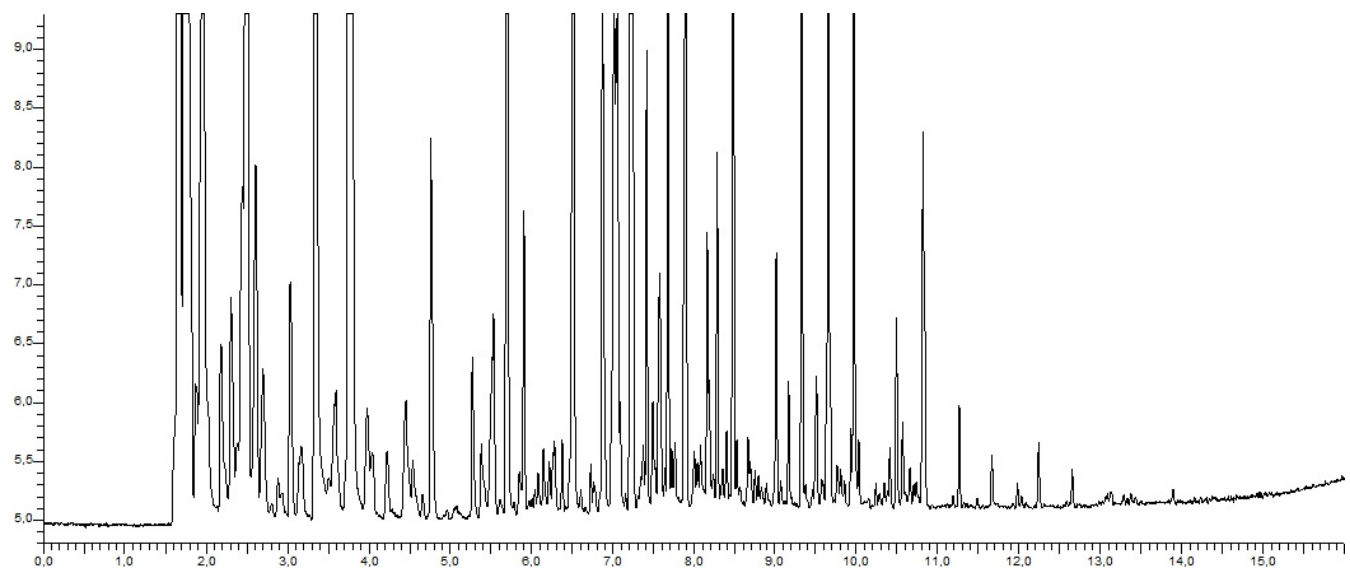

Figuur 84 Gaschromatogram van vluchtige stoffen in monster TK3-1 
Gaschromatogrammen van gemiddeld tot niet vluchtige stoffen

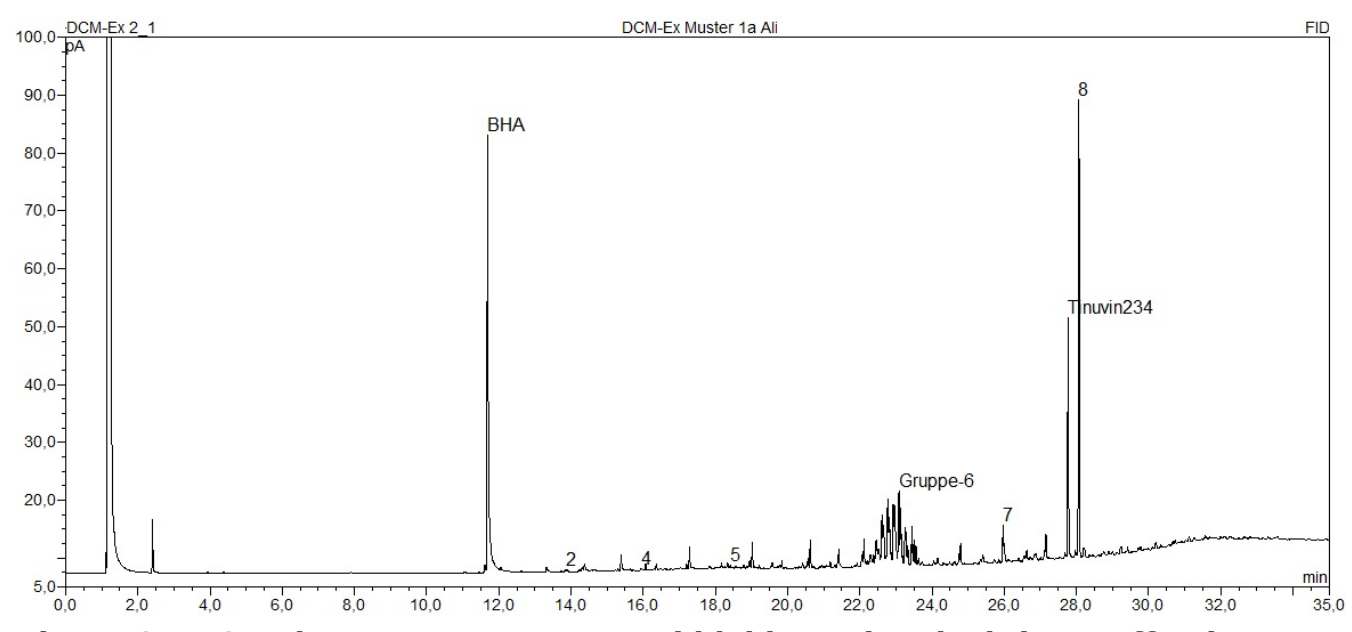

Figuur 85 Gaschromatogram van gemiddeld tot niet vluchtige stoffen in monster TK3-1

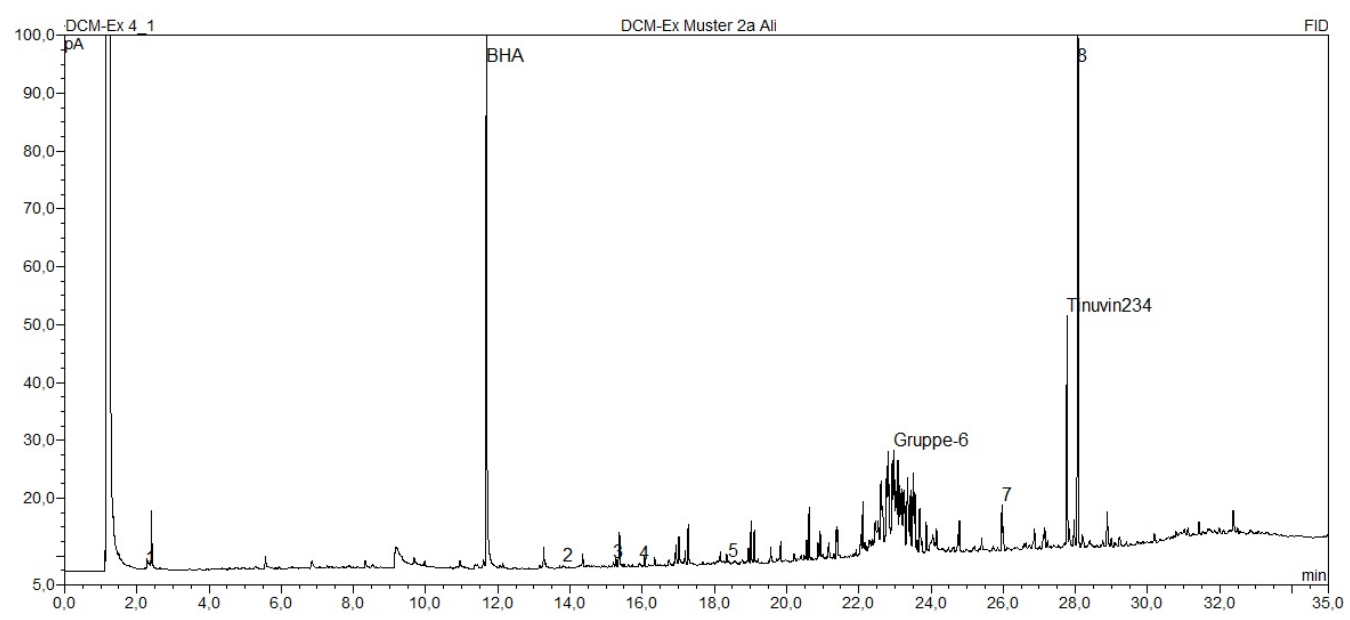

Figuur 86 Gaschromatogram van gemiddeld tot niet vluchtige stoffen in monster TK3-2

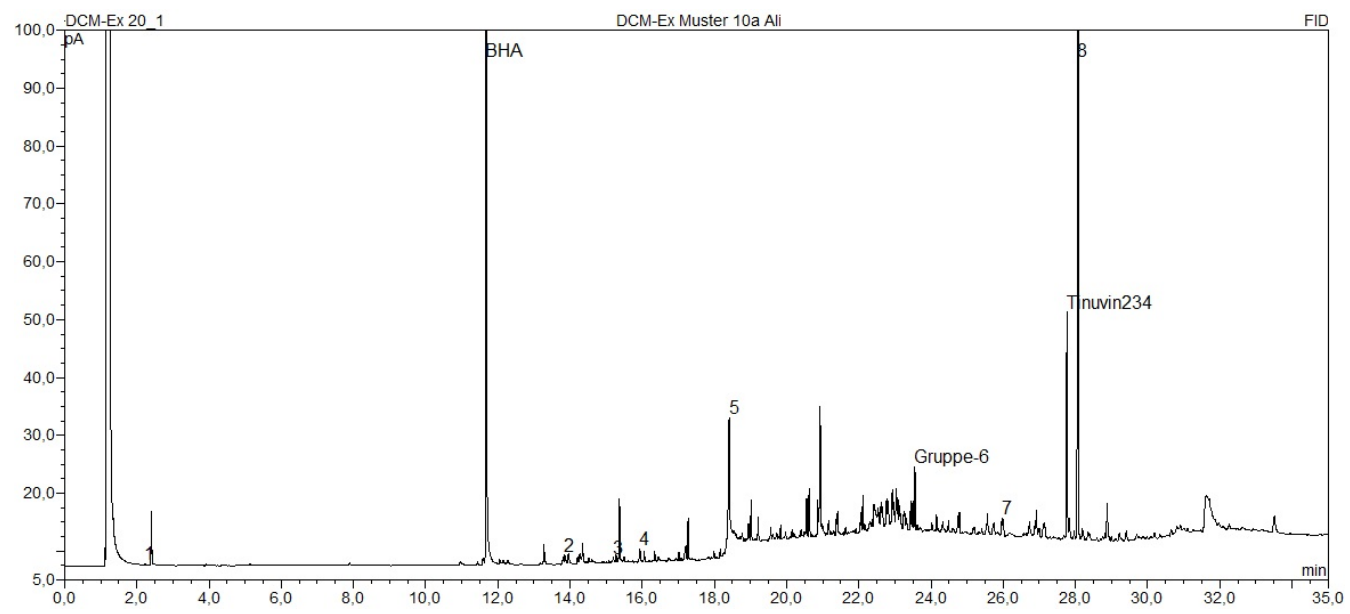

Figuur 87 Gaschromatogram van gemiddeld tot niet vluchtige stoffen in monster TK3-3 
$\underline{\text { Kwantificatie van de aangetroffen stoffen }}$

Tabel 20 Kwantificatie van de aangetroffen gemiddeld tot niet vluchtige stoffen in monsters genomen van verschillende wijken in Utrecht.

\begin{tabular}{|c|c|c|c|c|c|}
\hline \multirow[t]{2}{*}{ Piek } & \multirow{2}{*}{$\begin{array}{l}\text { Retentietijd } \\
\text { (min) }\end{array}$} & \multirow[t]{2}{*}{ Identificatie } & \multicolumn{3}{|c|}{ Concentratie (mg/kg) } \\
\hline & & & TK3-1 & TK3-2 & TK3-3 \\
\hline 1 & 2.4 & Niet geïdentificeerd & $<1$ & $<1$ & $1.3 \pm 0.1$ \\
\hline 2 & 13.9 & Dioctylether & $2.8 \pm 1.0$ & $5.1 \pm 1.1$ & $10.5 \pm 0.1$ \\
\hline 3 & 15.2 & Ethyhexyl salicylate & $<1$ & $8.1 \pm 3.4$ & $5.0 \pm 1.5$ \\
\hline 4 & 15.9 & Menthyl salicylate & $3.2 \pm 0.1$ & $6.9 \pm 1.6$ & $13.1 \pm 0.7$ \\
\hline 5 & 18.5 & Oliezuur & $3.1 \pm 2.0$ & $2.5 \pm 1.5$ & $83.4 \pm 114$ \\
\hline 6 & $22.4-22.7$ & $\begin{array}{l}\text { Di-isononyl-1,2- } \\
\text { cyclohexaandicarboxylaat (DINCH) }\end{array}$ & $1030 \pm 281$ & $1820 \pm 192$ & $760 \pm 51$ \\
\hline 7 & 26.0 & Bis(2-ethylhexyl)ftalaat (DEHP) & $37.5 \pm 3.9$ & $28.8 \pm 10.8$ & $14.9 \pm 1.1$ \\
\hline 8 & 28.1 & Geoxideerd Irgafos 168 & $421 \pm 68$ & $552 \pm 85$ & $556 \pm 24$ \\
\hline
\end{tabular}




\section{Bijlage 5 Additionele data taak 4}

Kwantificatie van de aangetroffen stoffen

Tabel 21 Kwantificatie van de aangetroffen gemiddeld tot niet vluchtige stoffen in monsters genomen van LDPE-folie na vier weken in een container met PMD-afval en in een container met restafval.

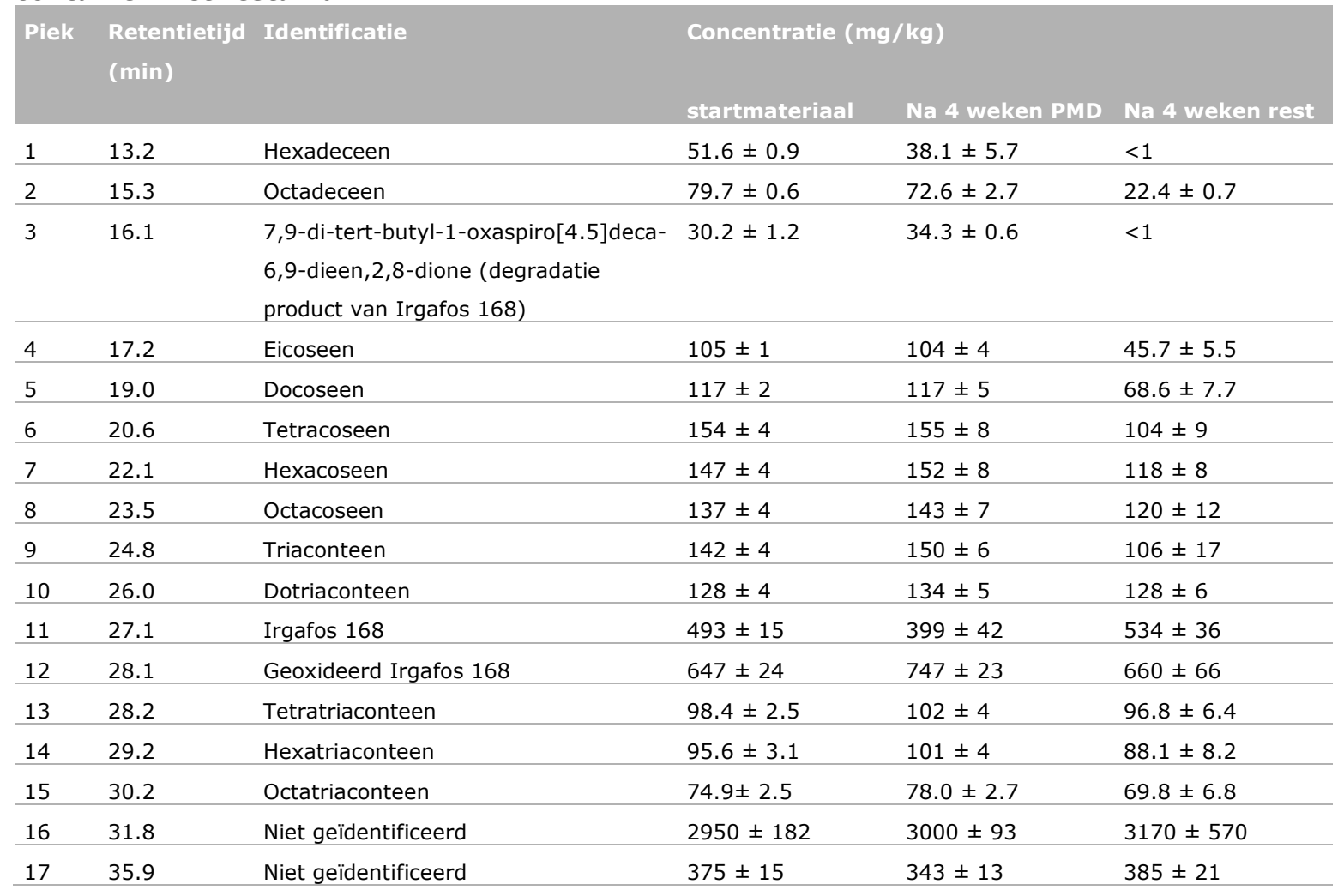





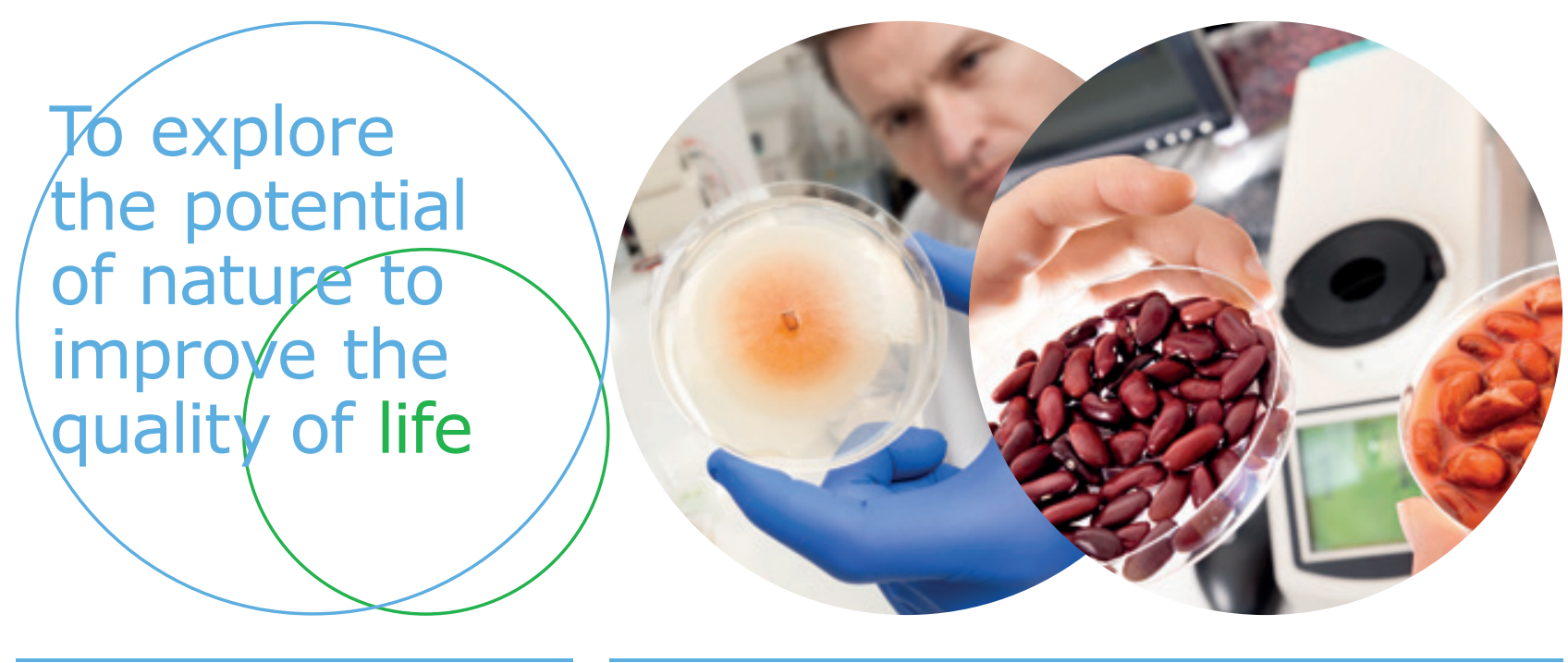

Wageningen Food \& Biobased Research Bornse Weilanden 9

6708 WG Wageningen

www.wur.nl/wfbr

info.wfbr@wur.nl

Rapport 2033

ISBN 978-94-6395-368-9
De missie van Wageningen University \& Research is 'To explore the potential of nature to improve the quality of life'. Binnen Wageningen University \& Research bundelen Wageningen University en gespecialiseerde onderzoeksinstituten van Stichting Wageningen Research hun krachten om bij te dragen aan de oplossing van belangrijke vragen in het domein van gezonde voeding en leefomgeving. Met ongeveer 30 vestigingen, 5.000 medewerkers en 12.000 studenten behoort Wageningen University \& Research wereldwijd tot de aansprekende kennisinstellingen binnen haar domein. De integrale benadering van de vraagstukken en de samenwerking tussen verschillende disciplines vormen het hart van de unieke Wageningen aanpak. 